\title{
A governança no conselho gestor da Área de Proteção Ambiental Bororé- Colônia, no extremo sul do município de São Paulo.
}

Dissertação apresentada à Escola de Artes, Ciências e Humanidades da Universidade de São Paulo para obtenção do título de Mestre em Ciências do Programa de Pós-Graduação em Mudança Social e Participação Política.

Área de concentração:

Participação Política e Desenvolvimento Local

Orientador:

Professor Doutor Sidnei Raimundo 
A governança no conselho gestor da Área de Proteção Ambiental BororéColônia, no extremo sul do município de São Paulo.

Versão corrigida

Dissertação apresentada à Escola de Artes, Ciências e Humanidades da Universidade de São Paulo para obtenção do título de Mestre em Ciências do Programa de Pós-Graduação em Mudança Social e Participação Política.

Área de concentração:

Participação Política e Desenvolvimento Local

Orientador:

Professor Doutor Sidnei Raimundo 
Autorizo a reprodução e divulgação total ou parcial deste trabalho, por qualquer meio convencional ou eletrônico, para fins de estudo e pesquisa, desde que citada a fonte.

CATALOGAÇÃO-NA-PUBLICAÇÃO

(Universidade de São Paulo. Escola de Artes, Ciências e Humanidades. Biblioteca)

Castro, Juliana Ferreira de

A governança no conselho gestor da Área de Proteção Ambiental

Bororé-Colônia, no extremo sul do município de São Paulo / Juliana

Ferreira de Castro ; orientador, Sidnei Raimundo. - São Paulo, 2016 $181 \mathrm{f}$. : il

Dissertação (Mestrado em Ciências) - Programa de Pós-

Graduação em Mudança Social e Participação Política, Escola de Artes, Ciências e Humanidades, Universidade de São Paulo

Versão corrigida

1. Proteção ambiental - São Paulo (SP). 2. Áreas de

Conservação - São Paulo (SP). 3. Área de Proteção Ambiental -

São Paulo (SP). 4. Participação política. 5. Gestão ambiental -

São Paulo (SP). 6. APA Bororé-Colônia. I. Raimundo, Sidnei, orient. II. Título

CDD 22.ed. - 363.7098161 
Nome: CASTRO, Juliana Ferreira de

Título: A governança no conselho gestor da Área de Proteção Ambiental Bororé-Colônia, no extremo sul do município de São Paulo.

Dissertação apresentada à Escola de Artes, Ciências e Humanidades da Universidade de São Paulo para obtenção do título de Mestre em Ciências do Programa de Pós-Graduação em Mudança Social e Participação Política.

Aprovada em: 13/11/2015

\section{Banca Examinadora}

Prof. Dro Helder Henrique de Faria Instituição: Instituto Florestal

Prof. Dro Eduardo de Lima Caldas

Instituição: Universidade de São Paulo - Escola de Artes, Ciências e Humanidades

Prof. Dro Reinaldo Tadeu Boscolo Pacheco

Instituição: Universidade de São Paulo - Escola de Artes, Ciências e Humanidades 


\section{AGRADECIMENTOS}

Ao Professor Dro Sidnei Raimundo, meu orientador, por sua presença de espírito contagiante, por tratar seus alunos espontaneamente como colegas e iguais e pelo raciocínio claro e calmo para lidar com problemas extremamente complexos que tirariam a calma e a altivez da maioria das outras pessoas. Muito obrigada professor, seu bom humor constante e seu empenho me motivam muito e sua orientação transcende essa dissertação.

Ao pesquisador científico do Instituto Florestal, da Secretaria de Meio Ambiente, Helder Henrique de Faria, sua capacidade intelectual e técnica, seu comprometimento, responsabilidade, ética e afeto pela gestão das unidades de conservação me motivaram e me motivam a seguir o caminho profissional que escolhi, palavras ensinam, mas o exemplo arrasta. Muito obrigada pelas contribuições e reflexões neste trabalho.

A Diego Lustre Gonçalves, técnico da Secretaria do Verde e do Meio Ambiente (SVMA), pela grande colaboração durante toda a pesquisa, muito obrigada. A Alice Calado, técnica da SVMA, pelo seu apoio e contribuição com este estudo, muito obrigada. A Jânio Ferreira, técnico da SVMA, pela elaboração do mapa que ilustra este trabalho, muito obrigada. As unidades de conservação municipais do extremo sul de São Paulo contam com profissionais muito comprometidos, cujo trabalho técnico permeado de muita dedicação e amor tem sido o fator fundamental para o enfrentamento das dificuldades que perpassam essas UC.

Aos conselheiros da APA Bororé-Colônia por acreditarem no seu papel na gestão da unidade de conservação e em especial a Eduardo Rocha, André, Anatália, Mariana e Melander por terem contribuído com seus depoimentos para esta pesquisa. Muito obrigada.

Aos meus pais, Belinha e Geraldo, pelo amor, carinho e apoio que sempre me dedicaram e por terem me ensinado importantes valores nessa vida. Muito obrigada por tudo.

Ao meu melhor amigo, meu companheiro, Rodrigo, por seu amor, por seu apoio, pela alegria que me traz e pelo sentido que me implica à vida. Muito obrigada cuy. 
A minha irmã, Patricia, pelo carinho e apoio que sempre me dedicou e por ser um exemplo em sua determinação e em seu amor por sua profissão. Muito obrigada.

Aos amigos e colegas do Grupo de Pesquisa Territorialidades, Políticas Públicas e Conflitos na Conservação do Patrimônio pela dedicação, motivação, crenças, atitudes e discussões inspiradoras. Muito obrigada Paulinha, Denise, Ale, Paulo, Fabricio, Thalita e Solange.

Aos amigos e colegas da Coordenadoria de Educação Ambiental, da Secretaria de Meio Ambiente, primeiro pelo imenso apoio, fundamental para a concretização deste estudo, e segundo pela postura, pelas reflexões e por dedicarem suas horas de trabalho em busca de um estado democrático, representativo, equitativo, transparente e justo. Muito obrigada Gabi, Adrianão, Ceci, Carolzinha, Aline, Dani, Carolé, Gilson, Rachel, Paulo, Roberta, Fabi, Hélia, Gustavo, Brunão, Edu, Simone, Bianca e Vinicius.

Aos amigos e colegas da Coordenadoria de Fiscalização Ambiental e da Fundação Florestal, da Secretaria de Meio Ambiente, pelas reflexões, provocações e motivações que o belo trabalho da Formação Socioambiental nas unidades de conservação estaduais me trouxe. Muito obrigada Beatriz, Rodrigo, Wagner e Adriana.

Aos professores Dro Eduardo Caldas e Dro Reinaldo Pacheco pelas arguições construtivas que me permitiram desnublar horizontes e vislumbrar novas perspectivas para a continuidade deste estudo. A participação dos senhores na banca oxigenou minhas reflexões. Muito obrigada professores. 


\section{RESUMO}

CASTRO, J. F. de. A governança no conselho gestor da Área de Proteção Ambiental Bororé-Colônia, no extremo sul do município de São Paulo. 2015. 171 f. Dissertação (Mestrado) - Escola de Artes, Ciências e Humanidades, Universidade de São Paulo, São Paulo, 2015.

Em todo o mundo a natureza está sendo impactada, os processos de desigualdade econômica e política se consolidam e as práticas de conservação acabam sendo pouco equitativas, colaborativas e sistematicamente conectadas (IUCN, 2014). Há grandes desafios para que seja consolidada a conservação da natureza, fomentado o desenvolvimento de sociedades sustentáveis e cumpridos os direitos humanos e a integração da sociedade na gestão ambiental pública é um dos caminhos apontados para enfrentá-los. As Áreas de Proteção Ambiental (APA) são as categorias de unidade de conservação que ocupam a maior extensão dos territórios terrestre e marinho protegidos no Brasil e objetivam compatibilizar a conservação do patrimônio natural com a melhoria da qualidade de vida das pessoas que habitam esses territórios (BRASIL, 2011). Por serem formadas por terras públicas e privadas, por abarcarem, em geral, grandes extensões territoriais e por serem, normalmente, dotadas de elevados graus de ocupação humana, as APA apresentam complexos processos sociais, econômicos e políticos, além de abrigarem pessoas e instituições que possuem diferentes relações e entendimentos com relação aos recursos naturais que se encontram naquele território, o que decorre em diferentes usos e concepções sobre aquelas unidades de conservação. No extremo sul do município de São Paulo, foi instituída em 2006 a APA Bororé-Colônia, em uma zona rural, produtora e repositora de água, na qual habitam cidadãos que estão constantemente buscando resistir às pressões da metrópole e que possuem um referencial mais ligado ao ambiente rural. $\mathrm{O}$ objetivo deste estudo é analisar como se dá a governança no conselho gestor da APA Bororé-Colônia, ou seja, como interagem o governo e as diversas organizações sociais, como se relacionam com os cidadãos e como são tomadas as decisões tendo em vista o bom exercício do poder para o cumprimento responsável dos objetivos da unidade de conservação. Este estudo contribui para entender a potencialidade desse fórum em promover a participação social na gestão ambiental pública, além de identificar os entraves que se apresentam a essa possibilidade. Os métodos empregados consistiram na definição do referencial teórico; com destaque para 
os princípios e critérios de "boa" governança na gestão de unidades de conservação (GRAHAM; AMOS; PLUMPTRE, 2003), na aplicação de entrevistas junto aos conselheiros, na observação não participante nas reuniões do conselho gestor da APA Bororé-Colônia e em incursões na unidade de conservação acompanhando o gestor. O conselho gestor da APA Bororé-Colônia é um colegiado que permite a interação entre o poder público e as diversas organizações sociais que se relacionam com a APABC, incluindo representantes das camadas que foram historicamente alijadas das tomadas de decisão. O colegiado enfrenta grandes dificuldades, mas possui grande potencial como agente político e espaço de ensinoaprendizagem, além de permitir que os atores sociais dialoguem sobre assuntos ainda não conversados e que sejam construídas coletivamente alternativas que contem com o comprometimento de todos os conselheiros.

Palavras-chave: governança, unidades de conservação, conselho gestor, participação social, gestão ambiental pública. 


\section{ABSTRACT}

CASTRO, J. F. de. Governance in the managing council of the Environmental Protected Area BororéColônia, in the southern city of São Paulo. 2015. $171 \mathrm{f}$. Thesis (MS) - School of Arts, Sciences and Humanities, University of São Paulo, São Paulo, 2015.

Worldwide nature is being impacted, the economic inequality and political processes are consolidated and conservation practices end up being inequitable, non collaborative and systematically not connected (IUCN, 2014). There are great challenges on nature conservation consolidation, on fostering the development of sustainable societies and human rights practiced, so the integration of society in public environmental management is one of the highlighted ways to address them. The Environmental Protection Areas (APA in portuguese) are the categories of protected area occupying the greater extent of terrestrial and marine protected areas in Brazil and aim to reconcile the conservation of natural heritage to improving the quality of life of the people who inhabit these territories (BRAZIL, 2011). Because they are made up of public and private lands, by covering generally large territorial extensions and generally endowed with high levels of human occupation, the APA have complex social, economic and political processes. In addition, it shelters people and institutions that have different relations and understandings about natural resources that are in that territory, stated by different usages and conceptions of those protected areas. At the southern end of the municipality of São Paulo was established in 2006 the APA-Bororé Colônia, in a rural area, a water producer and replenisher, in which citizens live, have a more connected reference to the rural environment and are constantly seeking to resist the pressures of the metropolis. The objective of this study is to analyze how governance in the managing council of APA-Bororé Cologne is built, that is, how they interact government and various social organizations, how they relate to citizens and how decisions are taken in view of the good exercise of power to the responsible fulfillment of the protected area goals. This study contributes to understand the potential of this forum to promote social participation in public environmental management, and to identify the obstacles that present themselves to this possibility. The methods consisted in defining the theoretical framework; highlighting the principles and criteria of "good" governance in the management of protected areas (GRAHAM; AMOS; Plumptre, 2003), by applying interviews with counselors, by non- 
participant observation in the managing council meetings of the APA Bororé-Colônia and through incursions into the protected area guided by its manager. The managing council of the APA Bororé-Colônia is a board that allows interaction between the government and the various social organizations that relate to $A P A B C$, including representatives of the layers that have historically been sidelined from decision-making. The collegiate faces great difficulties, but has great potential as a political agent and a teaching-learning space, besides allowing stakeholders to dialogue on issues not yet conversed, so that they built collectively alternatives that can count on the commitment of all directors.

Keywords: governance, protected areas, managing council, social participation, public environmental management. 


\section{LISTA DE SIGLAS}

AMCSA - Associação dos Moradores da Chácara Santo Amaro

AMIB - Associação dos Moradores Locais do Bororé

ANEPA - Associação Nacional dos Produtores de Agregados para Construção Civil

APA - Área de Proteção Ambiental

APABC - Área de Proteção Ambiental Bororé-Colônia

ATIBORÉ - Associação de Turismo da Ilha do Bororé

CADES - Conselho Municipal de Meio Ambiente e Desenvolvimento Sustentável

CNPQ - Conselho Nacional de Desenvolvimento Científico e Tecnológico

COOPERAPAS - Cooperativa Agroecológica dos Produtores Rurais e de Água Limpa da Região

Sul de São Paulo

COOPERPAC - Cooperativa de Catadores Seletivos do Parque Cocaia

CT - Câmara Técnica

DEPAVE - Departamento de Parques e Áreas Verdes

DERSA - Desenvolvimento Rodoviário S/A

EIA - Estudo de Impacto Ambiental

EMAE - Empresa Metropolitana de Água e Energia

FEMA - Fundo Estadual de Meio Ambiente e Desenvolvimento Sustentável

FF - Fundação Florestal

GT - Grupo de Trabalho

ICMBIO - Instituto Chico Mendes de Biodiversidade

IF - Instituto Florestal

ISA - Instituto Socioambiental

IUCN - International Union for Conservation of Nature

MEI - Micro Empreendedor Individual

MOGAVE - Associação Movimento Garça Vermelha

ONG - Organização Não Governamental

OSCIP - Organização da Sociedade Civil de Interesse Público

PDE - Plano Diretor Estratégico da Cidade

PESM - Parque Estadual da Serra do Mar

$\mathrm{PL}$ - Projeto de Lei 
PNM - Parque Natural Municipal

PNUD - Programa das Nações Unidas para o Desenvolvimento

RBCV - Reserva da Biosfera do Cinturão Verde da Cidade de São Paulo

RIMA - Relatório de Impacto Ambiental

RMMC - Rodoanel Metropolitano Mário Covas

SABESP - Companhia de Saneamento Básico do Estado de São Paulo

SEHAB - Secretaria Municipal de Habitação

SEMPLA - Secretaria Municipal de Planejamento

SGS / GCM - Secretaria de Governo Municipal

SMA - Secretaria do Meio Ambiente do Estado de São Paulo

SMC - Secretaria Municipal de Cultural

SMS - Secretaria Municipal de Saúde

SMSU / GCM - Secretaria Municipal de Segurança Urbana

SPPA - Subprefeitura de Parelheiros

SPPS - Subprefeitura de Capela do Socorro

SVMA - Secretaria Municipal do Verde e do Meio Ambiente

TCA - Termo de Compensação Ambiental

UCs - Unidades de Conservação

USP - Universidade de São Paulo

SNUC - Sistema Nacional de Unidades de Conservação

Zeis - Zonas Espaciais de Interesse Social

Zepam - Zona Especial de Preservação Ambiental 


\section{Sumário}

INTRODUÇÃO

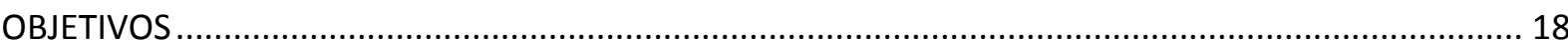

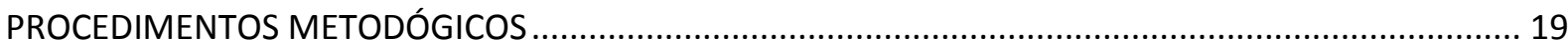

CAPÍTULO 1

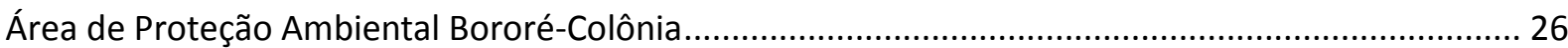

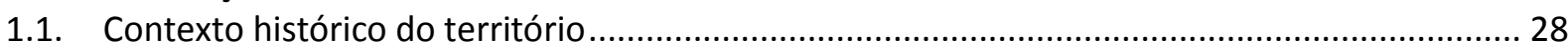

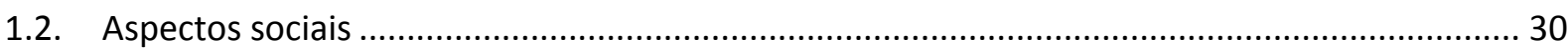

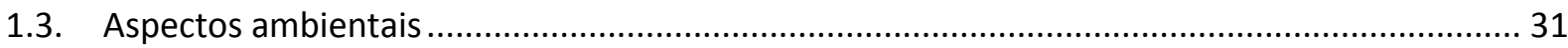

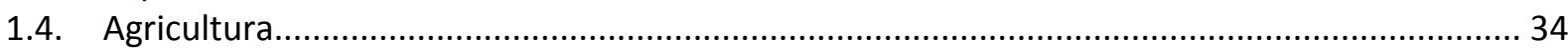

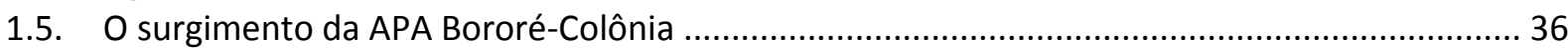

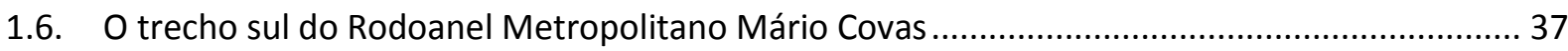

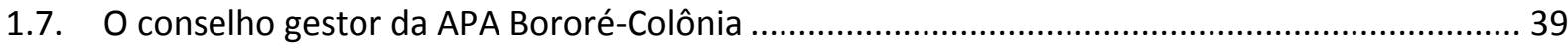

1.8. As demais unidades de conservação do extremo sul do município de São Paulo ...................... 59

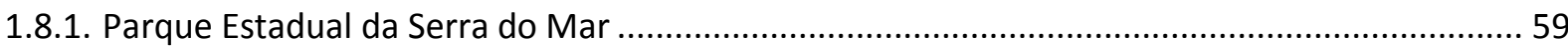

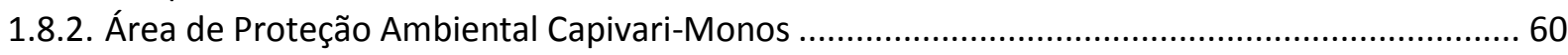

1.8.3. Parques Naturais Municipais Jaceguava, Itaim, Bororé e Varginha .......................................... 61

CAPÍTULO 2

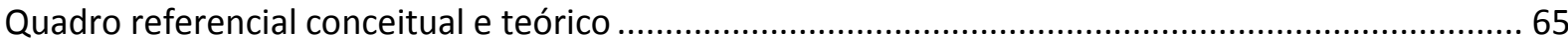

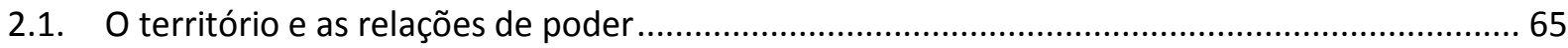

2.2. Unidades de Conservação e participação social na gestão ambiental pública........................... 70

2.3. Governança e "boa" governança na gestão de unidades de conservação.................................. 77

2.4. Aspectos das políticas públicas que influenciam na governança dos conselhos gestores de

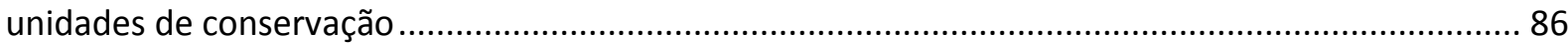
CAPÍTULO 3

A governança em análise no Conselho gestor da APA Bororé-Colônia ............................................. 94

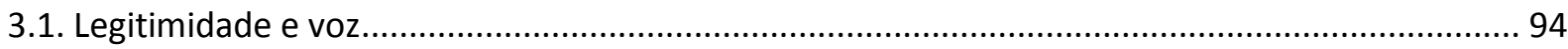

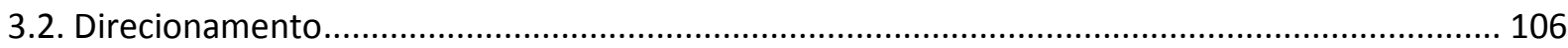

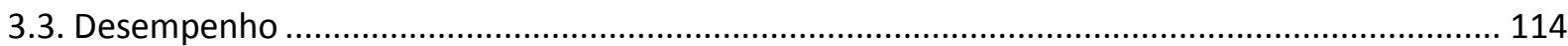

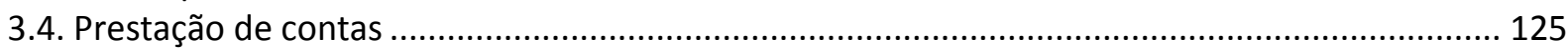

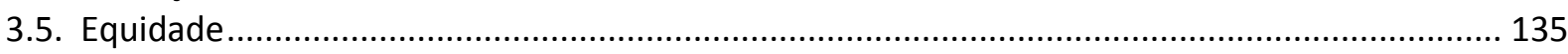

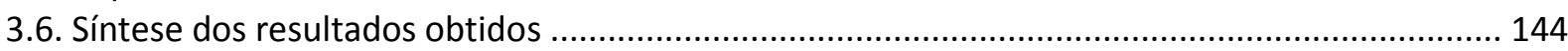

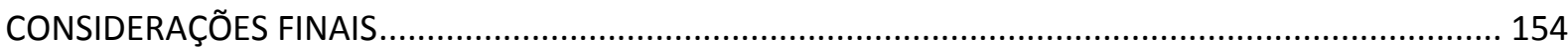

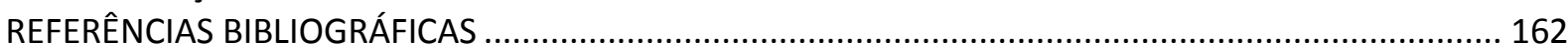

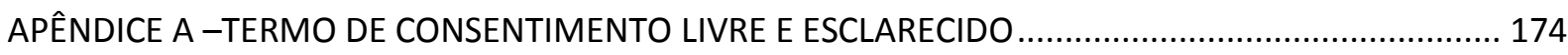

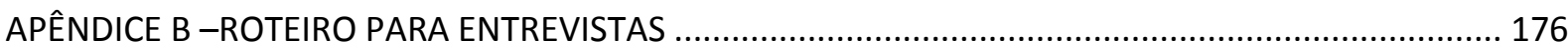

ANEXO A -LOCALIZAÇÃO DA APA BORORÉ-COLÔNIA E_PARQUES NATURAIS MUNICIPAIS BORORÉ,

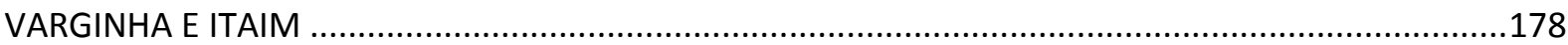

ANEXO B -CONTEXTO DA PARTICIPAÇÃO SOCIAL NA POLÍTICA AMBIENTAL................................... 180 


\section{INTRODUÇÃO}

As unidades de conservação (UCs), instituídas pela Lei Federal no 9.985/2000 (BRASIL, 2000), e as demais áreas protegidas pelo mundo constituem a principal estratégia para a conservação da biodiversidade, contribuindo para a redução da extinção de espécies, garantindo serviços ecossistêmicos fundamentais, conservando espaços naturais significativos cultural e socialmente (IUCN, 2009), além de oferecem a oportunidade de promover o desenvolvimento de sociedades sustentáveis e a participação cidadã na gestão ambiental pública. Entretanto, os desafios para que estas áreas atinjam seus objetivos e obtenham eficiência de manejo e gestão são gigantes (FARIA, 1993; IBAMA, 2007).

Há uma corrente no meio técnico conservacionista que indica que, na prática, o poder público que é o gestor das unidades de conservação, acaba contraditoriamente sendo uma grande ameaça para elas. Ausência de recursos humanos em número suficiente e capacitados para realizar a gestão, situação fundiária irregular, inexistência de Planos de Manejo, conselhos gestores inexistentes ou que não atingem resultados, desmatamento, caça, ocupações irregulares, fiscalização inexistente ou ineficiente e descarte de produtos oriundos de ações criminosas são frequentes em diversas UCs no Brasil, demonstrando ameaças ao Sistema Nacional de Unidades de Conservação (SNUC) ${ }^{1}$. Ao se criar UCs ou administrá-las é necessário um suporte adequado para o manejo, que envolve planejamento, capacidade institucional, conhecimentos gerados e disponíveis, suporte legal (FARIA, 2007) e ferramentas e alternativas para que a sociedade participe da gestão ambiental.

Historicamente, as comunidades vizinhas e os habitantes das unidades de conservação são excluídos de sua gestão e sofrem as consequências das restrições impostas pela área protegida, desfrutando muito pouco dos seus benefícios ou mesmo sendo tolhidos de suas práticas cotidianas (RAIMUNDO, 2009). Para autores como Diegues (2000), a biodiversidade pertence tanto ao domínio natural quanto ao cultural, mas é a cultura enquanto conhecimento que permite que as populações tradicionais possam entender a

\footnotetext{
${ }^{1}$ Lei Federal no 9.985/2000.
} 
biodiversidade, realizar sua representação mental, fazer seu manuseio e também enriquecêla, em uma situação em que se pode falar em etno-bio-diversidade. O primeiro modelo implantado de Parque no Brasil, no caso consolidado pelo Parque de Itatiaia criado em 1937, considera toda a sociedade como igual, não distinguindo as comunidades tradicionais e outras correlatas, e entende os espaços como santuários, que para garantirem a conservação da biodiversidade devem permanecer intocados pelo homem (DIEGUES, 2001). Essa abordagem de gestão tem gerado grandes problemas para muitas comunidades, além de não ter garantido a proteção da biodiversidade, e, embora muitos já compartilhem de uma visão conectada com o universo social, as heranças do modelo de entendimento que está em superação ainda se fazem presente no cotidiano.

Nas últimas décadas, a partir de eventos como a Conferência de Estocolmo em 1972; a publicação do Relatório Brundtland em 1987 pelas Nações Unidas; a 2a Conferência das Nações Unidas sobre Meio Ambiente e Desenvolvimento - Rio 92; a Cúpula Mundial sobre Desenvolvimento Sustentável em 2002; e os Congressos Mundiais de Parques em 1992 e em 2003 ampliou-se o espaço entre os técnicos do poder público e entre os estudiosos para um entendimento de que a integração entre o homem e a natureza é fundamental para a manutenção e o alcance da qualidade de vida, e para a conservação da biodiversidade. Na Conferência Nacional de Meio Ambiente de 2003, especialistas de entidades ambientais e representantes de governo do país apontaram que há duas formas para se pensar uma unidade de conservação: desconectada do foco social, ou como um espaço para a proteção da natureza e para a promoção da vida digna e sustentável; e o primeiro caminho não tem apontado bons resultados, ao contrário (MMA, 2004).

A abordagem social é fundamental na gestão das unidades de conservação e é necessário compreender as diferenças presentes na sociedade para se buscar a garantia de participação daqueles cidadãos tradicionalmente excluídos. O fortalecimento dos canais de diálogo entre a sociedade e a compreensão da proteção da natureza associada à questão social é de fundamental importância para delinear como será o futuro do Sistema Nacional de Unidades de Conservação no Brasil (MEDEIROS; IRVING; GARAY, 2006). Mas como alertou a chefe do Parque Nacional da Tijuca² em 2006, Sra. Sonia L. Peixoto, "esse processo é complexo e implica [n]a construção de cidadania e participação como elementos centrais

\footnotetext{
2 Parque Nacional mais visitado do Brasil nos anos de 2010, 2011 e 2012 (ICMBIO, 2012).
} 
da sustentabilidade social e ambiental nas práticas de gestão" (IBASE, 2006, p.5). Em meio a todo esse processo, o termo participação vem sendo submetido a uma apropriação discursiva que tem contribuído para seu esvaziamento e imprecisão, em uma retórica que acaba por proporcionar, inclusive, situações de opressão (PARAísO, 2005). É necessário qualificar essa participação para não incorrer no erro de fazer um uso genérico e vago do termo.

Os mecanismos-chave para a participação da sociedade na gestão das unidades de conservação estão contidos nos principais instrumentos de gestão participativa previstos pelo Sistema Nacional de Unidades de Conservação: o Plano de Manejo, o conselho gestor (IRVING, et al., 2006), e as consultas públicas previstas antes da criação das UC ${ }^{3}$. Esses mecanismos de participação social são jovens, sua origem remete a Constituição de 1988 que criou instrumentos e formas legais de institucionalizar a participação social na gestão do meio ambiente, como as audiências públicas, os fóruns participativos e os conselhos gestores (SANTILLI; SANTILLI, 2002).

A preocupação em elaborar procedimentos metodológicos que possam ser utilizados para monitorar o manejo de áreas protegidas existe desde a década de 1980 (IUCN, 1984; IUCN, 1986 apud FARIA, 2007) e está longe de ser esgotada, pois era e continua sendo de extrema necessidade para a busca da eficiência de manejo das unidades de conservação (FARIA, 2007, 20144). Porém, a abordagem destes estudos originais estava mais pautada pelas lentes da preservação ambiental e não da participação da sociedade na gestão ambiental pública. Com o passar dos anos, os gestores das UC passaram a receber mais responsabilidades com a inclusão e ampliação da pauta da dimensão social na gestão, mas o sistema público não tem evoluído na mesma velocidade. Considerando este pano de fundo, a governança em conselhos gestores de UC é um tema que merece atenção da comunidade acadêmica.

A região do extremo sul do município de São Paulo vem ganhando mais visibilidade diante de sua importância na produção hídrica e do seu quadro de vulnerabilidade social. 0 poder público, em todas as esferas, tem implantado ações ${ }^{5}$ para mitigar os impactos da

\footnotetext{
${ }^{3}$ Conforme consta no Decreto no 4.340/2002 que regulamenta o SNUC.

${ }^{4}$ Declaração oral proferida durante o exame de qualificação da autora no PROMUSPP, em 2014.

5 Programa Mananciais, Programa 100 Parques, venda de crédito de carbono, Programa Córrego Limpo, Programa de Aceleração do Crescimento (RADOLL, 2014).
} 
ocupação humana sobre o manancial (RADOLL, 2014). Com oito unidades de conservação, entre seis parques e duas áreas de proteção ambiental $(\mathrm{APA})^{6}$, a região passa por uma oportunidade de ampliação dos processos de envolvimento da população na gestão ambiental publica.

As áreas de proteção ambiental são a categoria mais representativa do Sistema Nacional de Unidades de Conservação, abarcam cerca de 30,19\% (426.273 km²) do território brasileiro continental e marinho abrangido por unidades de conservação (BRASIL, 2011). Trata-se de uma importante categoria, principalmente em áreas que passam por processos de expansão urbana, pois intenciona conceber o ordenamento da ocupação humana com a sustentabilidade dos recursos naturais (BRASIL, 2011).

A Área de Proteção Ambiental Bororé-Colônia (APABC), implantada em 2006, possui grande relevância nesse cenário, pois é uma unidade de conservação de gestão municipal com um conselho gestor deliberativo ${ }^{7}$, aspecto inovador, pois difere das APA estaduais, que possuem conselhos consultivos. A APABC é habitada por diversos núcleos populacionais, 0 que pode ser uma fragilidade do ponto de vista da conservação, mas também pode ser entendido como um grande recurso na caracterização da função e papel social dessa unidade de conservação. O conselho gestor da APABC é o espaço legitimado para a participação dos diferentes atores sociais que atuam no território da UC na gestão ambiental pública.

Tendo por referência a melhoria da qualidade de vida da sociedade atrelada a conservação ambiental, a participação dos cidadãos na gestão ambiental pública - em especial aqueles tradicionalmente excluídos - e não se pautando pelos interesses do capital, este estudo apresenta uma reflexão sobre a participação vislumbrando a governança do conselho gestor da APA Bororé-Colônia. A análise leva em conta as interações entre as estruturas, processos e tradições que determinam como o poder e as responsabilidades são exercidos, como as decisões são tomadas, e como os cidadãos e os stakeholders tem sua voz (GRAHAM; AMOS; PLUMPTRE, 2003).

\footnotetext{
${ }^{6}$ Parque Estadual da Serra do Mar, Parque Natural Municipal Varginha, Parque Natural Municipal Jaceguava, Parque Natural Municipal Itaim, Parque Natural Municipal Bororé, Parque Natural Municipal Cratera de Colônia, Área de Proteção Ambiental Bororé-Colônia e Área de Proteção Ambiental Capivari-Monos.

${ }^{7}$ A APA Capivari-Monos, vizinha da APA Bororé-Colônia, também está sob a gestão municipal e foi a primeira Área de Proteção Ambiental do Estado de São Paulo a instituir um conselho deliberativo, logo seu modelo foi incorporado na APABC.
} 
Para se preservar a relação de honestidade e transparência com o leitor é importante considerar que este trabalho tem uma tendência a se solidarizar com o gestor da unidade de conservação. Tal fato se explica pelo afeto da pesquisadora com o tema e por sua atuação profissional na área ambiental como servidora pública da Secretaria de Meio Ambiente do Estado de São Paulo. Esta conjuntura Ihe permite compreender imbróglios do poder público que limitam e desmotivam seus profissionais e faz emanar um sentimento de solidariedade com os colegas que procuram em suas lidas cotidianas cumprir qualitativamente com o papel do Estado, enfrentando as ingerências do Governo e suas atuações permeadas de intencionalidades a favor do poder hegemônico e de grupos sociais específicos.

Baseando-se no trabalho intitulado "Governance Principle for Protected Areas in the 21st Century", desenvolvido por Graham, Amos e Plumptre (2003) durante o V Congresso Mundial de Parques ${ }^{8}$, fez-se uso dos princípios e critérios que caracterizam a "boa" governança em unidades de conservação para compor o principal fecho de luz que iluminou a análise sobre o conselho gestor da APA Bororé-Colônia. Atuando como uma lente que trouxe nitidez ao que este fecho iluminara, foi incorporado na análise o referencial teórico de território (HAESBAERT, 2004; RAFFESTIN, 1993), territorialidade (HAESBAERT, 2004; RAFFESTIN, 1993), relações de poder (HAESBAERT, 2004; RAFFESTIN, 1993), Sistema Nacional de Unidades de Conservação (BRASIL, 2000; BRASIL, 2002; MEDEIROS; IRVING; GARAY, 2006), participação social (ARNSTEIN, 2002; BORDENAVEY, 1985; DEMO, 1988; GOHN, 2003; LOUREIRO; AZAZIEL; FRANCA, 2003; QUINTAS, 2005), conselhos gestores de unidades de conservação (ABERS; KECK, 2008; ICMBIO, 2014; IRVING et al, 2006, TATAGIBA, 2005), políticas públicas (SOUZA, 2006), arenas (LOWI, 1972; COELHO, 2004), redes de políticas públicas (MASSARDIER, 2006; KLIJN, 1998), construção da agenda (KINGDON, 2006), burocratas de nível de rua (MEYERS; VORSANGER, 2010) e discricionariedade (SUBIRATS, 2006).

Este estudo integra o Grupo de Pesquisa Territorialidades, Políticas Públicas e Conflitos na Conservação do Patrimônio $(\mathrm{EACH} U S P)^{9}$, cujo foco de análise consiste nas atividades e interesses dos segmentos da sociedade que atuam sobre essa temática,

\footnotetext{
8 O V Congresso Mundial de Parques foi promovido pela International Union for Conservation of Nature (IUCN) e ocorreu em Durban, África do Sul.

9 Home Page do Grupo de Pesquisa Territorialidades, Políticas Públicas e Conflitos na Conservação do Patrimônio: http://dgp.cnpq.br/dgp/espelhogrupo/2100076260361857.
} 
destacando seus conflitos, enlances e formas de interferência dessa relação nas dinâmicas sociais, tanto no espaço urbano, quanto no meio rural ou nas áreas protegidas. $O$ entendimento do grupo é que o exercício consciente e ativo nos processos participativos poderá se refletir na definição de políticas adequadas e coerentes para o desenvolvimento local, bem como promover mudanças sociais que dinamizem processos compreensivos das dimensões ambiental, política e cultural nos padrões de comportamento da sociedade.

Há de se reconhecer que esta pesquisa apresenta uma oportunidade de análise, não intenciona de forma alguma sugerir que está apontando uma verdade absoluta, e sim um ponto de vista, sendo possível haver várias análises para o mesmo assunto e para o encaminhamento das questões que dele derivam. Elementos teóricos e empíricos reunidos permitiram a construção da compreensão acerca da governança no conselho gestor da APA Bororé-Colônia. Espera-se que a discussão traga subsídios para o aprimoramento da participação social na gestão das áreas protegidas, fortalecendo o papel do conselho gestor da APABC como espaço de "boa" governança. 


\section{OBJETIVOS}

O objetivo deste trabalho é analisar a governança do conselho gestor da APA BororéColônia, ou seja, como interagem o governo e as diversas organizações sociais, como se relacionam com os cidadãos e como são tomadas as decisões tendo em vista o bom exercício do poder. Por bom exercício do poder se entende o cumprimento responsável dos objetivos da unidade de conservação e a promoção da melhoria da qualidade de vida das populações que a habitam. Esta pesquisa visa contribuir para entender a potencialidade do conselho gestor em promover a participação social na gestão ambiental pública, além de identificar os entraves que se apresentam a essa possibilidade.

Em uma perspectiva ampliada, intenciona-se colaborar no delineamento de ações e políticas socioambientais que visem fortalecer a participação social na gestão ambiental pública da APA Bororé-Colônia. Também há a pretensão de inspirar as demais unidades de conservação da região e quiçá do Estado a ampliar seus processos de gestão participativa.

Os objetivos específicos são (a) desenvolver um procedimento metodológico de análise da governança de conselhos gestores de unidades de conservação e (b) avaliar a situação do conselho gestor da APA Bororé-Colônia, baseado no roteiro proposto. 


\section{PROCEDIMENTOS METODÓGICOS}

Os próximos parágrafos abordam os caminhos de pensamento escolhidos e os procedimentos práticos adotados para se alcançar os objetivos propostos a partir do desenvolvimento de uma metodologia de análise qualitativa. São apresentadas as etapas para a construção do método adotado; o caso escolhido; a análise e as fontes de coleta de dados. A área de estudo será contextualizada no próximo capítulo.

As técnicas utilizadas nesta pesquisa, descritas a seguir, podem ser abordadas na concepção de métodos de pesquisa em outros estudos. Isso porque todas são estruturadas e fundamentadas, porém foram usadas parcialmente quando consideradas em todo seu potencial. Tal escolha parcial se dá em função da necessidade de se articular técnicas na construção deste percurso (método) e assim poder atender as finalidades desta pesquisa, na busca em se responder ao objetivo proposto.

\section{Relação do referencial teórico com o desenvolvimento da pesquisa}

Para estudar um fenômeno social cientificamente é muito relevante que o fenômeno seja perceptível, sensível e classificável, ainda que os conceitos trabalhados em seu referencial teórico e na explicação do fenômeno sejam abstratos. A construção do referencial teórico situa o olhar que deve dar subsídios à análise do objeto de estudo. A operacionalização do conceito é um resultado decorrente dos momentos em que se encontram comportamentos, características, estímulos ou fatos que representem esses conceitos.

O referencial teórico permite que o objeto seja lido e interpretado à luz de uma teoria, mas, nesse estudo, não se intenciona explicar o fenômeno observado por meio de construções teóricas. Propõe-se a apropriação da teoria, não para usá-la de forma dogmática, mas sim para operacionalizar o que ela oferece para a explicação e a análise do fenômeno sob um ponto de vista que não deseja se impor como verdade absoluta, apenas conjecturar. 
Desta forma, compreender a configuração do conceito de território, sua relação com as diversas formas de poder, a territorialidade e demais especificidades do território foi o ponto de partida para compreender o processo de envolvimento da sociedade na APA Bororé-Colônia. Em seguida, se investigou mais sobre o Sistema Nacional de Unidades de Conservação e as possibilidades de participação da sociedade neste contexto. Para aprofundar o conhecimento sobre a interação da sociedade com a gestão ambiental pública, o conceito de governança e os princípios e critérios de "boa" governança contribuíram para a instrumentalização e para a construção de um caminho metodológico qualitativo fundamental para a análise feita neste estudo. Para que a abordagem não ficasse rasa, os estudos sobre aspectos das políticas públicas que afetam a governança em conselhos gestores de unidades de conservação implicaram mais nitidez a interpretação presente nestas páginas, qualificando a discussão.

\section{Pesquisa bibliográfica e documental}

A construção do referencial teórico é fundamental, primeiro porque situa o objeto de pesquisa no conhecimento já produzido, segundo porque fornece as condições necessárias para a construção do olhar que norteia a análise e terceiro porque permite a análise dos dados levantados e seu confrontamento com o que a bibliografia coloca. Os conceitos e os referenciais teóricos que contribuíram na construção da lente que permeia o olhar presente neste estudo são aqueles já citados na página 16.

A etapa inicial da pesquisa consistiu na consulta a livros, textos acadêmicos, revistas científicas, publicações especializadas e documentos de instituições oficiais para a construção do referencial teórico apresentado. Foram levantados também os documentos que tratam da gestão de unidades de conservação no Brasil, no estado e no município de São Paulo.

Foram consultados o Regimento Interno do conselho gestor da APA Bororé-Colônia, o Plano de Gestão da APABC as leis de criação da APABC e dos Parques Naturais Municipais Jaceguava, Itaim, Bororé e Varginha. Pretendia-se examinar as atas das reuniões do conselho gestor da APABC compreendidas no período da pesquisa ${ }^{10}$, porém, até a conclusão da

\footnotetext{
${ }^{10}$ O período está compreendido entre outubro de 2013 e junho de 2015.
} 
dissertação elas não foram disponibilizadas para acesso público. Fato que demonstra a dificuldade em acessar informações públicas que permitam acompanhar o conselho em análise. Informativos de circulação local, manifestos de entidades, matérias publicadas em veículos de comunicação e outros correlatos que se mostraram pertinentes também foram consultados.

A análise dos documentos levantados foi realizada por meio de metodologia qualitativa, através de uma leitura hermenêutica. A pesquisadora tinha conhecimento de que poderia fazer uso de outras metodologias e ferramentas tecnológicas; como o software Nvivo para facilitar a organização das informações do corpus de documento e das entrevistas no que diz respeito à codificação, às regras de enumeração e à categorização. A opção pela metodologia adotada se deu pelo fato de que o caminho rumo à procura de uma resposta para o objetivo proposto nesta pesquisa não foi um processo cartesiano, e não o pode ser dada a complexidade do objeto de pesquisa. Se os documentos e as entrevistas fossem analisados de forma quantitativa estes seriam relativizados e a avaliação de suas ideologias, intencionalidades e contexto de criação seria posta em segundo plano, ao passo que se entende que essa perspectiva é mais importante para a análise, opinião compartilhada também por outros pesquisadores como Lüdke e André (1986).

\section{Definição de princípios de análise}

Os princípios de "boa" governança e seus critérios empregados neste estudo foram definidos a partir do trabalho "Governance Principles for Protected Areas in the 21st Century" (GRAHAM; AMOS; PLUMPTRE, 2003), apresentado no V Congresso Mundial de Parques, realizado em Durban, África do Sul, em $2003^{11}$. Na ocasião, foram propostos cinco princípios para analisar as estruturas de governança em áreas protegidas: Legitimidade $e$ Voz, Direcionamento, Desempenho, Prestação de Contas e Equidade.

A partir destes princípios os autores propõem uma série vinte e nove critérios, detalhados nas bases teóricas, vide quadro 6, que podem ser observados para sustentar a análise daqueles princípios. No presente estudo buscou-se a aplicação de todos os critérios, e se observou que alguns tiveram maior adequabilidade. A operacionalização foi construída

\footnotetext{
${ }^{11}$ No momento da definição deste referencial teórico este era o mais recente Congresso Mundial de Parques.
} 
de modo dinâmico, a partir da análise hermenêutica das entrevistas, das reuniões do conselho gestor da APA Bororé-Colônia, dos documentos legais e das incursões em campo. Essa análise procurou expor uma explicação coerente a partir da contextualização dos princípios aplicados à realidade observada.

\section{Entrevistas}

Nesta etapa tomou-se contato com os conselheiros do conselho gestor da APA Bororé-Colônia. Segundo Richardson a entrevista é uma grande oportunidade, para o autor

[...] a melhor situação para participar na mente de outro ser humano é a interação face a face, pois tem caráter, inquestionável, de proximidade entre as pessoas, e proporciona as melhores possibilidades de penetrar na mente, vida e definição dos indivíduos (RICHARDSON, 1999, p. 207).

A amostra foi composta por membros do conselho gestor da APA Bororé-Colônia, incluindo o gestor que atuou entre 2013 e 2014 e a gestora que assumiu em $2015^{12}$. O número da amostra não foi previamente determinado, se trabalhou com sua saturação, ou seja, na medida em que o discurso começou a se repetir foi encerrada a coleta de dados através de entrevistas (MINAYO, 2007).

No total foram entrevistados cinco conselheiros além dos dois gestores. Entre os conselheiros, quatro representavam a sociedade civil e um representava uma instituição do poder publico. Os entrevistados foram: Anatália Jesus da Rocha Siriano, que ocupa a vaga titular da cadeira destinada a Associação de Moradores Locais do Bororé e é conselheira há quatro anos; André Luiz Vieira Barbosa, que ocupa a vaga titular da cadeira destinada às Associações de Ensino e Técnico-Científicas e é conselheiro há quatro anos; Mariana Andréa Gonçalves Belmont, que ocupa a vaga titular da cadeira destinada à Associação de Moradores Locais do Bairro do Colônia e é conselheira há quatro anos; Eduardo Melander Filho, que ocupa a vaga de suplente da cadeira destinada às OSCIPS ou às Organizações Nãogovernamentais ligadas à defesa do meio ambiente e é conselheiro há dois anos; e Carlos Eduardo Gomes da Rocha, representante titular da cadeira destinada à Empresa Metropolitana de Água e Energia (EMAE) e é conselheiro desde a primeira gestão.

\footnotetext{
12 Diego Lustre Gonçalves e Alice Maria Calado Melges.
} 
A entrevista foi feita de forma não estruturada, que também é chamada de entrevista em profundidade por Richardson (1999, p.208), segundo o autor "[...], visa obter do entrevistado o que ele considera os aspectos mais relevantes de determinado problema: as discrições de uma situação em estudo". A entrevista foi guiada, já que neste aspecto "o pesquisador conhece previamente os aspectos que deseja pesquisar e, com base neles, formula alguns pontos a tratar na entrevista" (RICHARDSON, 1999, p. 212).

Para a realização das entrevistas procurou se atender ao que dispõe a Resolução do Conselho Nacional de Saúde no 196/96 no que diz respeito aos aspectos éticos da pesquisa envolvendo seres humanos, ao processo de consentimento livre e esclarecido e os riscos e benefícios da pesquisa. Há um compromisso ético em voga com os entrevistados de publicização e retorno das informações aos interessados; as entrevistas transcritas foram devolvidas e pretende-se apresentar os resultados da pesquisa no conselho gestor da APA Bororé-Colônia. Uma cópia impressa da dissertação será entregue ao conselho e demais publicações que derivem deste estudo também serão compartilhadas com o colegiado. Antes de cada entrevista houve um termo de aceite para ser lido e assinado pelo entrevistado (APÊNDICE A), que foi desenvolvido com base nas reuniões do Grupo de Pesquisa do qual a pesquisadora é integrante.

Para gravar as entrevistas foi feito o uso de um mini gravador de voz digital da marca Sony, modelo PX 333. A análise das entrevistas, após suas transcrições foi feita por metodologia qualitativa, a mesma utilizada na análise documental, pelos mesmos motivos expostos anteriormente.

A elaboração das perguntas da entrevista se deu a partir do aprofundamento no referencial teórico já mencionado, com especial destaque para a "boa" governança em áreas naturais (GRAHAM; AMOS; PLUMPTRE, 2003), e foi complementada pela consulta bibliográfica de experiências semelhantes em outras localidades. As obras consultadas para essa complementação foram: a publicação do Ministério do Meio Ambiente "Gestão Participativa do SNUC" (MMA; 2004); a publicação do Instituto Brasileiro de Meio Ambiente e Recursos Renováveis (IBAMA) “Educação ambiental e gestão participativa em unidades de conservação" (LOUREIRO; AZAZIEL; FRANCA, 2003); a dissertação de mestrado de Luiz Cozzolino, pelo Programa EICOS (Psicossociologia de Comunidades e Ecologia Social) da UFRJ (Universidade Federal do Rio de Janeiro), intitulada "Unidades de conservação e os processos 
de Governança Local: o caso da APA do Sana (Macaé, RJ)" (COZZOLINO, 2005); o artigo derivado dessa dissertação intitulado "Gestão de unidades de conservação: um caminho teórico e metodológico possível a partir da ótica da governança na APA do Sana (Macaé-RJ)" (COZZOLINO; IRVING, 2006). Os desdobramentos do Grupo de Pesquisa integrado pela pesquisadora, principalmente no que diz respeito ao "Projeto de pesquisa: Participação Política e Turismo na Gestão de Áreas Naturais no Estado de São Paulo", aprovado no Conselho Nacional de Desenvolvimento Científico e Tecnológico (CNPq), processo n409448/2013-3, também contribuíram para a elaboração das perguntas. O roteiro que guiou as entrevistas encontra-se no APÊNDICE B.

\section{Participação nas reuniões do conselho gestor da Área de Proteção Ambiental Bororé- Colônia}

A pesquisa de campo mediante comparecimento nas reuniões do conselho gestor da APA Bororé-Colônia foi uma estratégia utilizada durante toda a pesquisa. Nesta etapa, a técnica de observação não participante foi utilizada quanto à ação do pesquisador frente ao fenômeno observado (RICHARDSON, 1999). Richardson (1999, p.259) indica que "(..) a observação, sob algum aspecto, é imprescindível em qualquer processo de pesquisa científica (...)", para o autor ela é a base de toda investigação no campo social, e pode ser utilizada em qualquer nível de complexidade da investigação científica. Na observação não participante o pesquisador apenas atua como espectador atento, procurando ver e registrar tudo que tem a ver com seu trabalho. Optou-se pela observação não participante assistemática, o que significa que a tarefa de observar é mais livre, sem fichas ou listas de registros (RICHARDSON, 1999).

Nesta etapa, foram registrados de maneira espontânea e assistemática os fatos e relatos obtidos ao longo dos eventos que trataram a temática abordada neste estudo. Também foi possível confrontar a interpretação advinda da análise do referencial teórico, dos documentos legais e das entrevistas com a observação da dinâmica de funcionamento do colegiado. Foram momentos fundamentais que permitiram o aprofundamento da análise sobre a governança no conselho gestor da APA Bororé-Colônia. 


\section{Incursões a campo na Área de Proteção Ambiental Bororé-Colônia}

Durante a pesquisa foram feitas no total sete incursões em campo, sendo três delas acompanhando o gestor da APA Bororé-Colônia em vistorias. Nesta etapa, também se fez uso da técnica de observação não participante (RICHARDSON, 1999). De modo complementar às demais etapas percorridas, essas visitas foram muito importantes para poder conhecer o território da APABC, seus habitantes, especificidades e confrontar essas impressões com as obtidas nos demais momentos da pesquisa, contribuindo para a análise da governança do conselho gestor da unidade de conservação. 


\section{CAPÍTULO 1}

\section{Área de Proteção Ambiental Bororé-Colônia}

Situada na região sul do município de São Paulo, a APA Bororé-Colônia foi criada pela Lei Municipal no 14.162, de 24 de maio de 2006. O ANEXO A apresenta um mapa detalhado da unidade de conservação. A APABC constitui uma categoria de UC de uso sustentável ${ }^{13}$. Ela é definida como ${ }^{14}$ :

[...] uma área em geral extensa, com um certo grau de ocupação humana, dotada de atributos abióticos, bióticos, estéticos ou culturais especialmente importantes para a qualidade de vida e o bem-estar das populações humanas, e tem como objetivos básicos proteger a diversidade biológica, disciplinar o processo de ocupação e assegurar a sustentabilidade do uso dos recursos naturais."

$\S 10$ A Área de Proteção Ambiental é constituída por terras públicas ou privadas.

$\S 20$ Respeitados os limites constitucionais, podem ser estabelecidas normas e restrições para a utilização de uma propriedade privada localizada em uma Área de Proteção Ambiental.

§ 3o As condições para a realização de pesquisa científica e visitação pública nas áreas sob domínio público serão estabelecidas pelo órgão gestor da unidade.

$\S 40$ Nas áreas sob propriedade privada, cabe ao proprietário estabelecer as condições para pesquisa e visitação pelo público, observadas as exigências e restrições legais.

§ 50 A Área de Proteção Ambiental disporá de um conselho presidido pelo órgão responsável por sua administração e constituído por representantes dos órgãos públicos, de organizações da sociedade civil e da população residente, conforme se dispuser no regulamento desta Lei.

\footnotetext{
${ }^{13}$ Lei Federal no 9.985/2000, Artigo 14으, Parágrafo I.

${ }^{14}$ Lei Federal no 9.985/2000, Artigo 15ㅇ․
} 
A APA Bororé-Colônia estende-se por nove mil hectares e está inserida em áreas administradas pelas Subprefeituras de Capela do Socorro - bairros do Bororé e parte do Varginha - e Parelheiros - bairros da Colônia Paulista e do Itaim -, no extremo sul do município de São Paulo (PREFEITURA MUNICIPAL DE SÃO PAULO, 2014a), conforme destacado na figura 1 , a seguir.

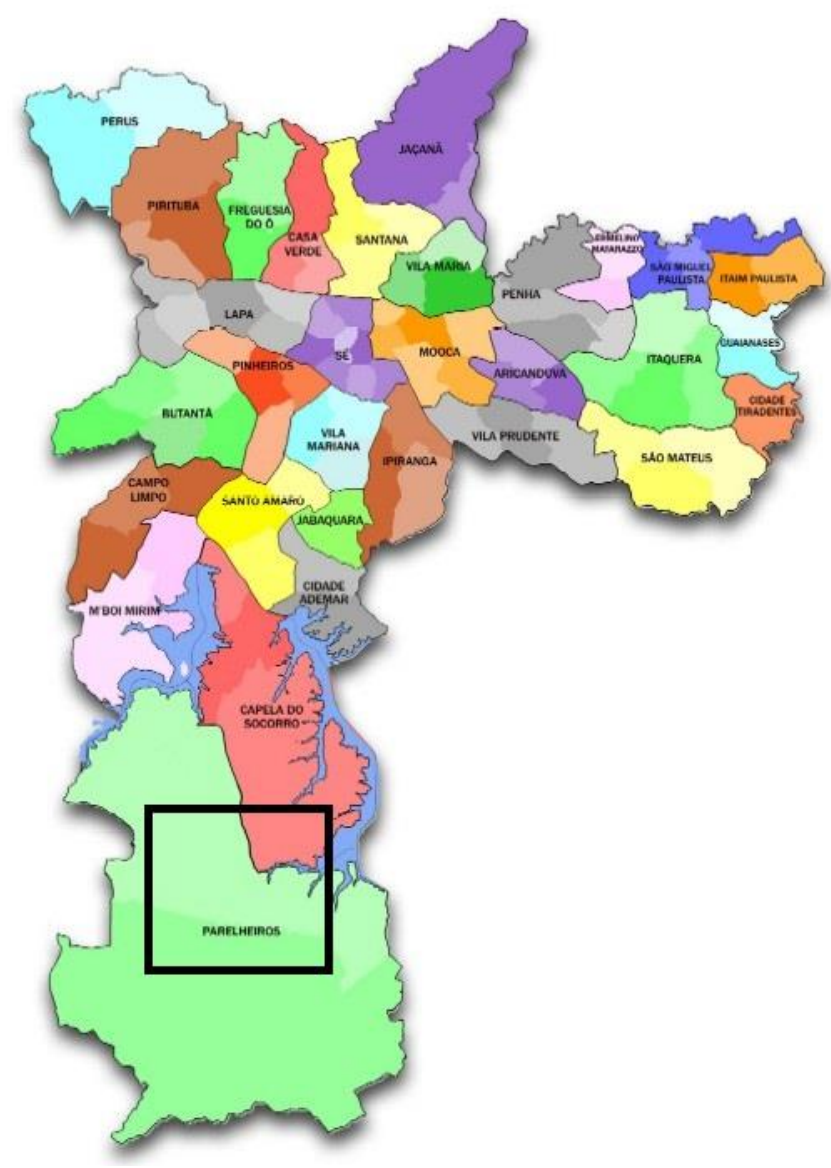

Figura 1 - Mapa das Subprefeituras do município de São Paulo com destaque para a área onde se insere a APABC.

Fonte: PREFEITURA MUNICIPAL DE SÃO PAULO, 2014b. Adaptado pela autora.

Em seus $90 \mathrm{~km}^{2}$ ainda predominam características tipicamente rurais, com uso e ocupação das terras voltadas para o ambiente rural, mas a comunidade local apresenta atividades urbanas, sendo a urbanização a grande modificadora da paisagem (RAIMUNDO et al., 2010). Na APA Bororé-Colônia há remanescentes de mata atlântica, agricultura convencional, agricultura orgânica, silvicultura, minerações, assentamentos urbanos regulares e irregulares, além de núcleos populacionais antigos de importância histórica e cultural (SANTOS, 2003). O que reflete em atores sociais com diferentes interesses e provavelmente diferentes valores com relação ao significado que para eles possuem o lugar 
onde está a $A P A B C$, seja a respeito da conservação da natureza, seja nas atividades econômicas permitidas. Os moradores locais se identificam com o território, possuem vínculo com o lugar e lidam cotidianamente com as pressões da metrópole (PORTO, 2004), por conta do avanço dos processos de urbanização.

\subsection{Contexto histórico do território}

Os habitantes da APA Bororé-Colônia e seu entorno são fruto de uma interação entre povos em uma mistura que produziu e ainda produz uma cultura rica e diversificada. Descendente de imigrantes; em especial alemães (figura 2) e japoneses, além de migrantes nordestinos e do interior de São Paulo, bem como comunidades de pescadores e de agricultores, além dos descendentes de paulistas e paulistanos, compõe a diversidade cultural da região (SANTOS, 2003).

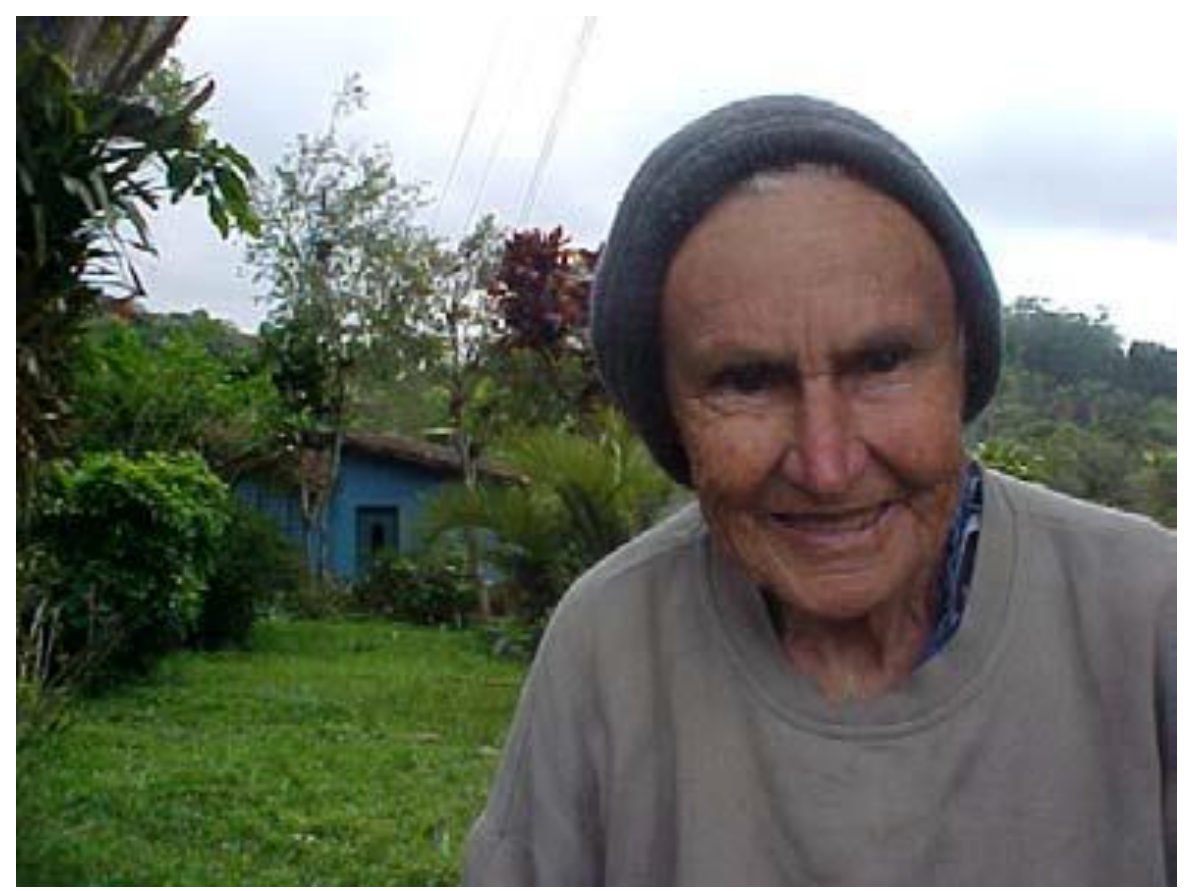

Figura 2 - Senhora Vitalina Reimberg, descendente de alemães do bairro de Colônia, aos 80 anos de idade (in memorian).

Fonte: SANTOS, 2003.

Para entender a realidade do território da APABC hoje precisamos voltar um pouco no passado. O território do extremo sul pertenceu até 1935 ao antigo município de Santo Amaro, e desde a colonização portuguesa Santo Amaro teve aldeamentos administrados pelos jesuítas, fazendo o uso de trilhas de índios que habitaram e ainda habitam a região para ligar a cidade ao litoral no período colonial. Em 1828 um decreto criou na região o 
bairro de Colônia, e noventa e quatro famílias alemãs foram deslocadas para lá. Os primeiros habitantes de Colônia dedicavam-se a agricultura e a extração de madeira (PREFEITURA MUNICIPAL DE SÃO PAULO, 2012).

Com a implantação da linha férrea da Cia. Carris de Santo Amaro, no final do século $X I X$, intensificou-se o processo de ocupação humana naquele ambiente. No começo do século XX havia uma grande produção de carvão na região, expandindo os limites da degradação e devastando a floresta (PREFEITURA MUNICIPAL DE SÃO PAULO, 2012). Somando-se a esse cenário, a construção das represas Guarapiranga (1906-1909) e Billings (1925-1927) intensificou a ocupação da região. Novos núcleos habitacionais surgiram com a linha férrea e com a construção das represas (PREFEITURA MUNICIPAL DE SÃO PAULO, 2012).

A ilha do Bororé (figura 3), que na verdade é uma península, se originou do represamento da Billings. No mesmo período, grupos de colonos japoneses também passaram a se estabelecer na região (PREFEITURA MUNICIPAL DE SÃO PAULO, 2012). Em 1935 o município de Santo Amaro foi anexado a São Paulo e a partir de 1950 a região foi se tornando mais urbanizada, com a chegada também de uma nova leva de migrantes, a maioria nordestinos e boa parte vinda do interior paulista (PREFEITURA MUNICIPAL DE SÃO PAULO, 2012).

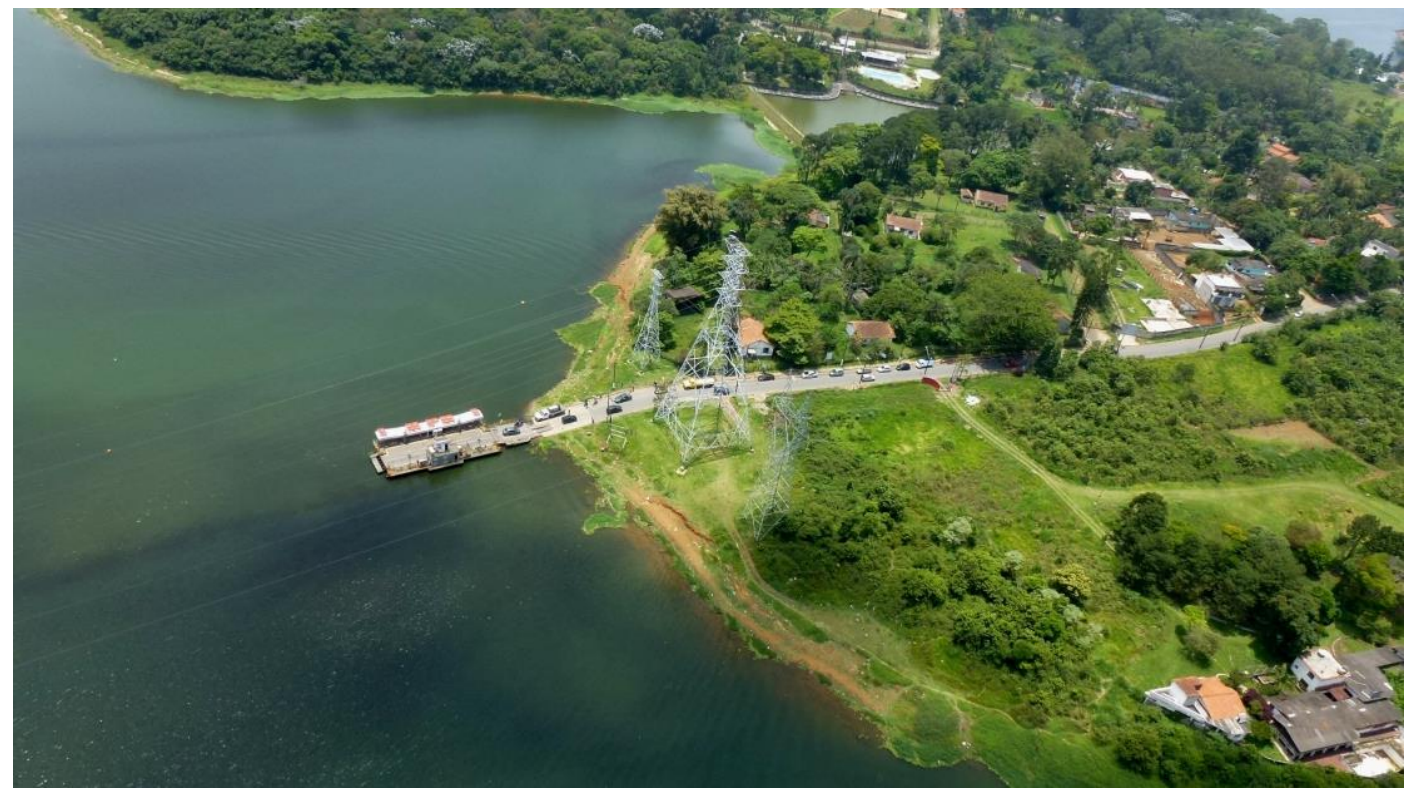

Figura 3 - Vista aérea da llha do Bororé com destaque para a 1a Balsa na Represa Billings. Fonte: PREFEITURA MUNICIPAL DE SÃO PAULO, 2015. 
Haja vista que a ocupação urbana já havia avançado sobre os mananciais, a partir da década de 60 , com as leis estaduais de proteção aos mananciais, começaram as tentativas de se organizar a urbanização na região (PREFEITURA MUNICIPAL DE SÃO PAULO, 2012).

\subsection{Aspectos sociais}

Em 2004, a população estimada da APA Bororé-Colônia era de 50.000 habitantes (GONÇALVES, 2010). Atualmente não há dados exatos sobre esse número, mas pelos indicativos observados nas vistorias e as frequentes denúncias de construções irregulares com moradias de baixo padrão no conselho gestor da unidade de conservação, ela cresceu exponencialmente. A população residente está aumentando e a pressão de novos loteamentos e novas moradias no território da APABC é recorrente, a fiscalização do poder público na região é deficitária.

No novo Plano Diretor Estratégico da Cidade (PDE), aprovado em 2014 e que vigorará por dezesseis anos, a área da APA Bororé-Colônia integrará a zona rural do município de São Paulo, com o intuito de conter a expansão horizontal da cidade e conservar o que resta de vegetação estimulando a melhoria da qualidade de vida da população por meio de atividades econômicas mais sustentáveis. Na área da APABC com o novo PDE também foram criadas Zonas Espaciais de Interesse Social (Zeis), destinadas a produção de moradia para famílias de baixa renda. As Zeis grafadas nessa área de proteção aos mananciais intencionam tanto reurbanizar e regularizar o que for possível quanto reassentar famílias que estão em áreas irregulares. Sem dúvida essa política pública irá gerar mais tensões na APABC.

Os habitantes da APA Bororé-Colônia em geral possuem um baixo padrão de moradia; mais de metade dos loteamentos é precária, o acesso aos serviços públicos é deficiente e pode-se afirmar que estas pessoas estão em situação de vulnerabilidade social (GONÇALVES, 2010). O abastecimento público não atende a todos os setores; o esgoto tampouco é tratado, o mais comum são fossas ou despejo direto nos corpos d'água; a energia elétrica ainda que seja disponibilizada à boa parte dos bairros é caracterizada por ligações clandestinas; as estradas de terra não passam por manutenção frequente tornando o deslocamento pela $A P A B C$ muitas vezes um desafio; o sistema de transporte público é ineficiente e amplia as dificuldades de deslocamento, apesar de estar a cerca de $30 \mathrm{~km}$ do centro da cidade leva-se cerca de duas horas para acessá-lo fazendo uso do transporte 
público; o serviço de saúde é insuficiente; a renda média desta população é baixa; e há criminalidade recorrente no território, características que reforçam o grau de vulnerabilidade social.

Os serviços públicos oferecidos nessa região são de baixa qualidade. Por se tratar de uma área de proteção aos mananciais ${ }^{15}$, cuja ocupação é proibida, o governo se ausenta pautando-se nesse argumento, investe muito pouco em mais equipamentos e serviços públicos, pois isso é reconhecer que há mais ocupação humana ali. Há um grande desencontro entre o que prevê a legislação e o que acontece na prática. A fiscalização é deficiente e não garante o cumprimento da lei de proteção aos mananciais; com isso a cada dia aparecem mais ocupações humanas irregulares. A questão socioambiental novamente é relegada ao segundo plano, a produção de água e os cidadãos tradicionalmente excluídos dos serviços sociais aparentemente não estão na agenda de prioridades do poder público.

\subsection{Aspectos ambientais}

São Paulo já ultrapassou os onze milhões de habitantes, mas, segundo a Prefeitura Municipal, cerca de $40 \%$ do território do município ainda está coberto por vegetação (PREFEITURA MUNICIPAL DE SÃO PAULO, 2015a). A Zona Norte, com a Serra da Cantareira, e a Zona Sul (figura 4) com o Parque Estadual da Serra do Mar e com as APA Bororé-Colônia e Capivari-Monos concentram as florestas mais conservadas.

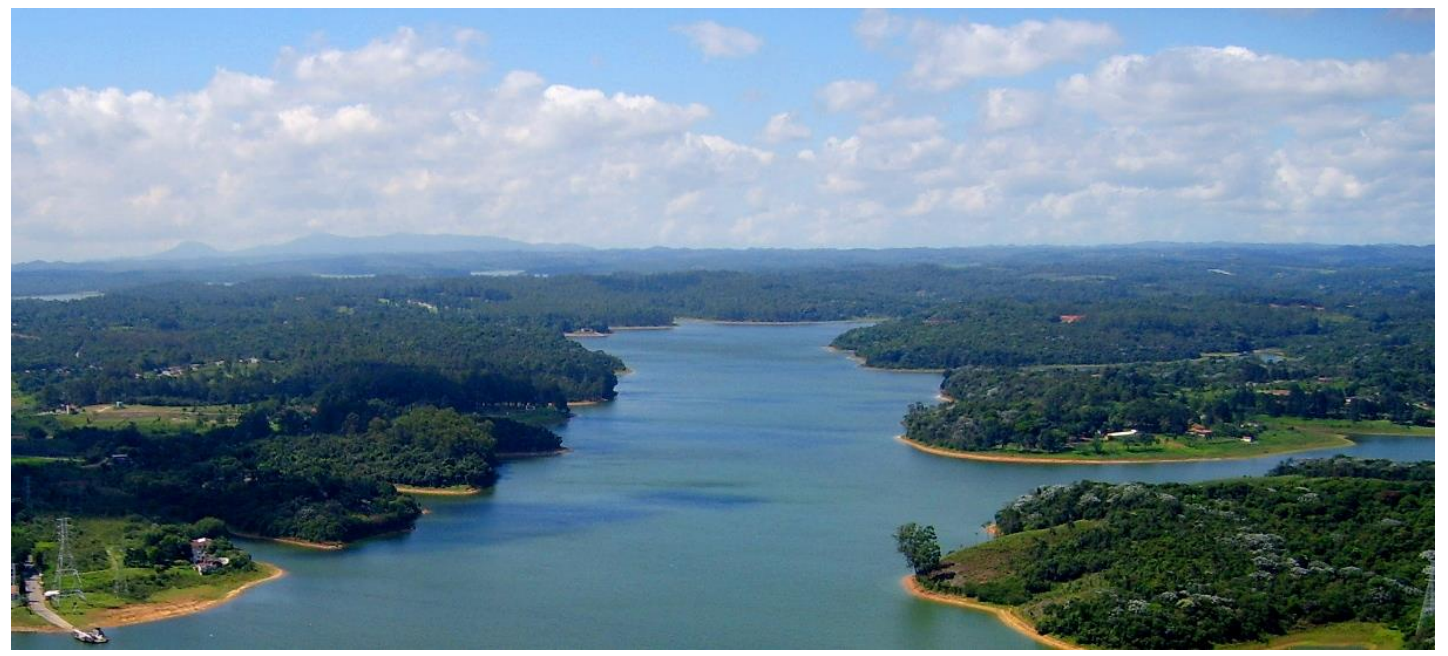

Figura 4 - Vista aérea das florestas da Zona Sul do município de São Paulo a partir da Represa Billings. Fonte: PREFEITURA MUNICIPAL DE SÃO PAULO, 2015.

\footnotetext{
15 Lei Estadual no 13.579/2009.
} 
As formações vegetais encontradas na APA Bororé-Colônia pertencem ao domínio da Mata Atlântica, que está entre as vinte e cinco regiões prioritárias para conservação no mundo, os chamados hotspots (PREFEITURA MUNICIPAL DE SÃO PAULO, 2012). Podem ser encontradas nas áreas de florestas da APABC; compostas principalmente pelos Parques Naturais Municipais Itaim, Bororé e Varginha, que serão apresentados adiante, plantas ameaçadas de extinção como o palmito-juçara (Euterpe edulis), a canela (Ocotea sp.), a palmerinha-prateada (Lytocaryum hoehnei) e diversas orquídeas. Animais como antas (Tapirus terrestris), pavões-do-mato (Phyroderus scutatus), bugio-ruivo (Alouatta clamitans), gatos-do-mato (Leopardus tigrinus) também são recorrentes nas áreas de mata da APABC (PREFEITURA MUNICIPAL DE SÃO PAULO, 2012).

A característica ambiental da APA Bororé-Colônia que atualmente tem maior visibilidade diz respeito à produção de água. A área da $A P A B C$ se sobrepõe a uma área de proteção aos mananciais, abrangendo parcialmente as bacias hidrográficas das represas Billings e Guarapiranga, mais especificamente as bacias do Bororé, do Taquacetuba (figura 5), do ribeirão Itaim, cabeceiras do Cocaia e parte da bacia do rio Parelheiros (SANTOS, 2003).

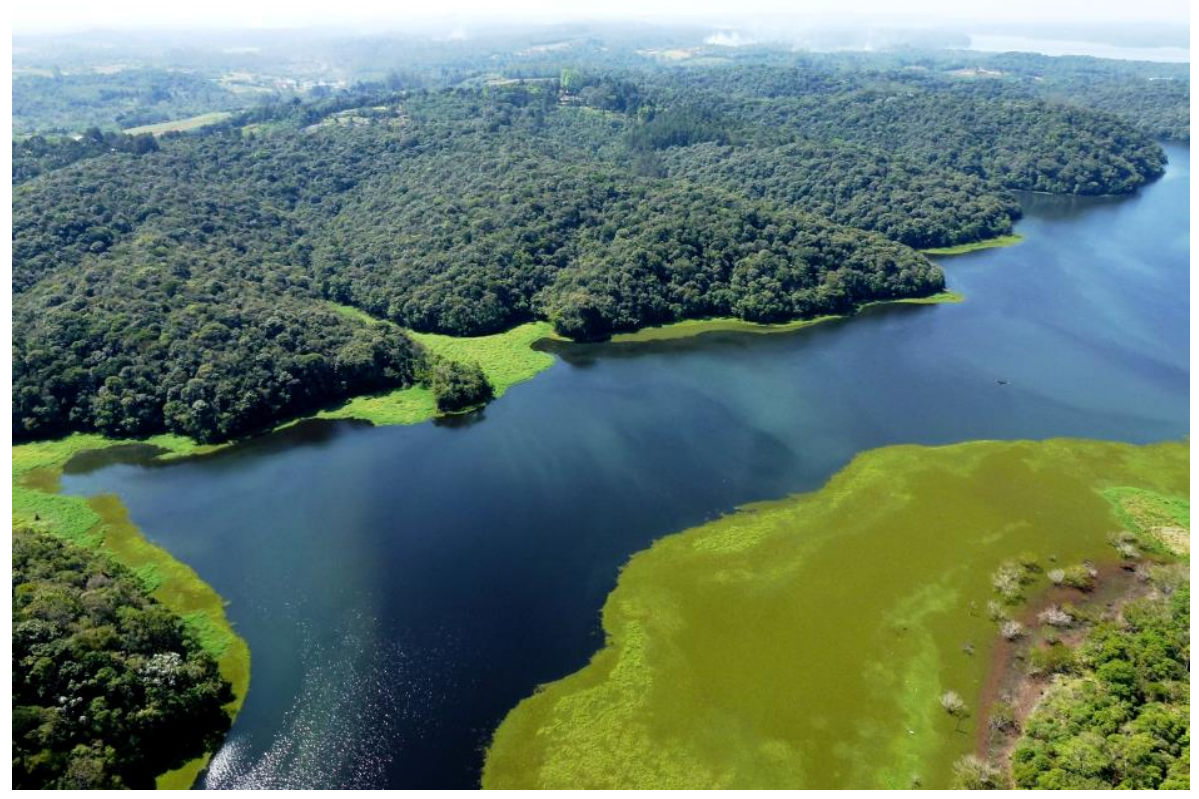

Figura 5 - Vista aérea do braço do Taquacetuba, Represa Billings, na APA Bororé-Colônia. Fonte: PREFEITURA MUNICIPAL DE SÃO PAULO, 2015. 
O Sistema Guarapiranga é um manancial muito importante para a Região Metropolitana de São Paulo, abastecendo cerca de 4 milhões de pessoas, ou seja, cerca de $20 \%$ da população, notadamente das regiões sul e oeste da metrópole (SABESP, 2014a). A represa Billings tem capacidade semelhante ao Sistema Cantareira ${ }^{16}$, mas ela é subaproveitada devido à contaminação das suas águas por metais pesados que inviabilizam seu uso para o abastecimento dos cidadãos (JACOBI, 2014 ${ }^{17}$ ).

A cidade de São Paulo passou de uma população de cerca de 270 mil habitantes no final do século XIX (SEADE, 2006 apud BORELLI, 2011) para mais de 20 milhões de habitantes no ano de 2014 (SEADE, 2014), sendo que cerca de 40\% de sua população vive em áreas irregulares (BORELLI, 2011). A demanda por água aumenta gradativamente, também é crescente a concentração populacional próxima a áreas de mananciais, gerando grandes impactos nessas fontes produtoras de água. A qualidade ambiental da APA Bororé-Colônia tem relação direta com a produção de água do Sistema Guarapiranga e Billings, e este assunto tem ganhado cada vez mais prioridade nas agendas governamentais devido ao quadro de escassez de água que aflige o $\operatorname{Estado}^{18}$ (SABESP, 2014).

A questão hídrica em São Paulo pode transformar a APA Bororé-Colônia em objeto de reivindicação política. A falta de água amplia o debate sobre sua produção e pode ampliar a demanda social por conservação e por mais atenção do poder público à população local, a exemplo do que aconteceu em Cubatão em 1985, onde o nascimento de bebês com defeitos genéticos graves decorrentes da poluição gerou um movimento de conscientização e resistência da população à expansão industrial (COSTA, 1996). A APA Bororé-Colônia pode ser revestida de forte conteúdo social e ampliar a discussão sobre o assunto, pois o tema tem grande potencial para mobilizar a atenção da sociedade e do poder público.

Outro aspecto ambiental relevante sobre a unidade de conservação, é que a APA Bororé-Colônia está inserida na Reserva da Biosfera do Cinturão Verde da Cidade de São Paulo (RBCV). A RBCV foi declarada pela Organização das Nações Unidas para a Educação, a Ciência e a Cultura (UNESCO), em 1994, área integrante da Reserva da Biosfera da Mata

\footnotetext{
16 Principal sistema de abastecimento do município de São Paulo.

17 Professor Dro Titular da Universidade de São Paulo do curso de Pós-Graduação em Ciência Ambiental (PROCAM) do Instituto de Energia e Ambiente (IEE) da USP. Fala proferida durante aula de Políticas Públicas de Meio Ambiente No Brasil: Dimensões Nacional, Regional e Local da Ação do Estado. Universidade de São Paulo. 03/12/2014. PROCAM/IEE/USP.

${ }^{18} \mathrm{Em} \mathrm{03/10/2014}$ o Sistema Cantareira estava com 6,4\% do volume útil acrescido da reserva técnica.
} 
Atlântica, criada três anos antes, em 1991, e cuja abrangência é interestadual. As Reservas da Biosfera do Cinturão Verde objetivam o desenvolvimento sustentável, a participação da comunidade local e da ciência, conciliando a conservação da diversidade biológica e cultural e o desenvolvimento econômico e social, através de parcerias entre as pessoas e a natureza (UNESCO, 2014).

\subsection{Agricultura}

Em grandes cidades como São Paulo, a APA Bororé-Colônia representa não apenas um refúgio para a conservação da biodiversidade, mas também um local de promoção de práticas tradicionais e alternativas de desenvolvimento econômico sustentável, sendo um importante espaço para aquelas pessoas que ainda vivem da agricultura (figura 6). Dos $1.523 \mathrm{~km}^{2}$ do município, cerca de $15 \%$ estão em zona rural, sendo que a zonal sul do município ocupa a maior parcela deste território (PREFEITURA DA CIDADE DE SÃO PAULO, 2015a).

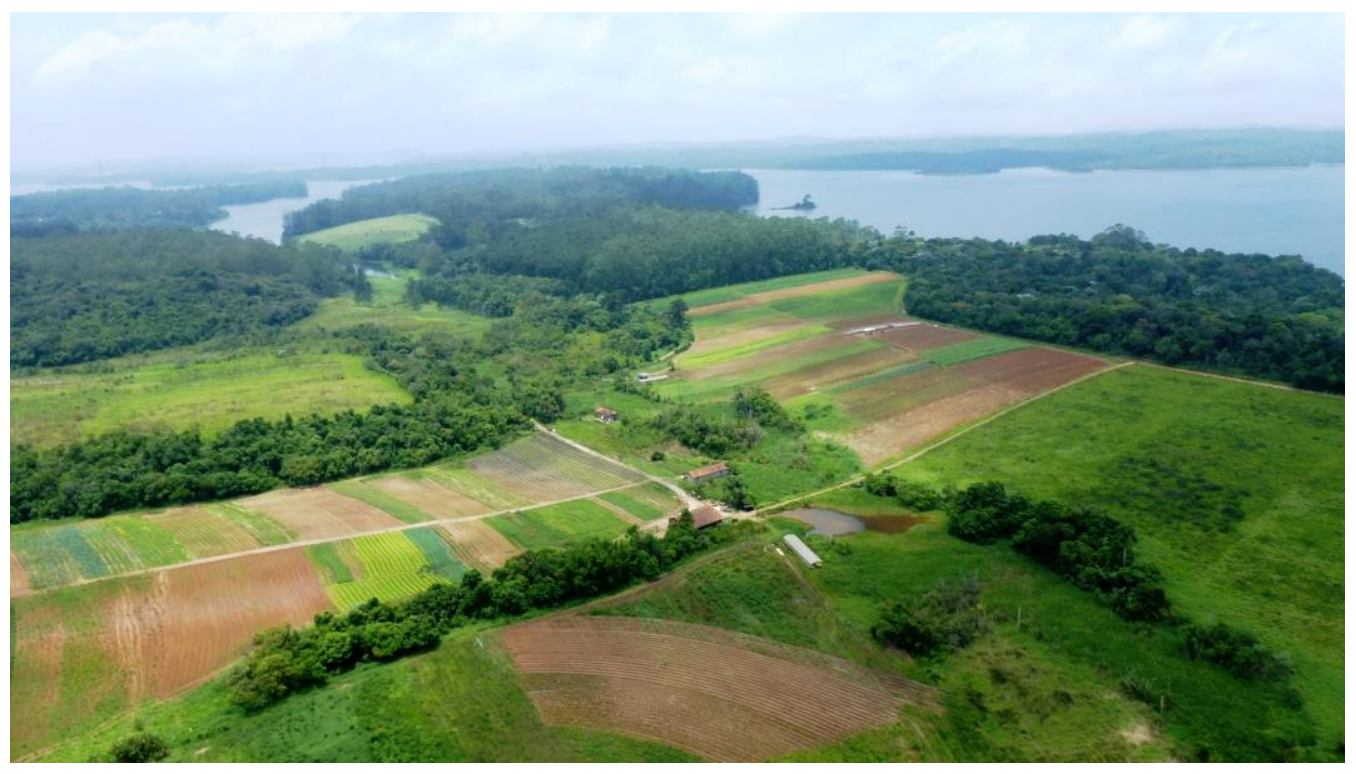

Figura 6 - Vista aérea de atividade agrícola na APA Bororé-Colônia.

Fonte: Prefeitura Municipal de São Paulo, 2015.

Há, em todo o município, cerca de quatrocentos agricultores resistindo à pressão da cidade; seja pela desvalorização do trabalho na terra, seja pelas invasões irregulares que poluem os mananciais e o solo, seja pela ausência de assistência técnica, pela precariedade 
das estradas rurais, ou pela dificuldade de acesso ao mercado (REITER et al., 2012). A agricultura que já foi muito importante na economia do extremo sul do município de São Paulo hoje enfrenta dificuldades, e as terras que acabam abandonadas são frequentemente invadidas e loteadas, aumentando a pressão e os impactos sobre o manancial e os remanescentes florestais.

Há potencial agrícola na região passível de ser fomentado de modo a incentivar uma atividade que preze pela permanência dos agricultores em suas terras, pela produção de alimentos de forma mais sustentável e orgânica, e que contribua para a proteção dos mananciais. Esse argumento é sustentado quando observamos a curta distância com o mercado consumidor, a existência de terras com potencial produtivo e baixo custo de manutenção, o fato de haverem moradores remanescentes dos migrantes japoneses e germânicos de tradição agrícola, a presença de água em abundância - embora sua qualidade seja contestável, a existência de rede viária para escoar a produção, a disponibilidade de energia elétrica e telefone em algumas propriedades e a existência de uma rede de serviços públicos básicos como escolas.

Na APA Bororé-Colônia são valorizadas práticas agrícolas menos agressivas ao meio ambiente, incentiva-se a agricultura familiar, bem como práticas como a permacultura, os sistemas agroflorestais, a agricultura orgânica, a biodinâmica. Há um contexto para a valorização das dimensões éticas, sociais e ambientais envoltas nessas propostas de agricultura. Existe um Selo de Indicação de Procedências Guarapiranga chamado Garça Vermelha que identifica os produtos da agricultura paulistana cultivados segundo as boas práticas agroambientais, ou seja, que atendem ao Programa Agricultura Limpa ${ }^{19}$ e ao Protocolo de Boas Práticas Agrícolas ${ }^{20}$ (REITER, et al., 2012).

Os desafios enfrentados pelos agricultores têm gerado bons frutos. Sua organização e seu trabalho conjunto Ihes permitiram oportunidades de participar da gestão ambiental pública, eles possuem assento e voz nos conselhos gestores das APA Bororé-Colônia e Capivari-Monos, bem como na Câmara Técnica de Agricultura e Desenvolvimento Rural (REITER, et al., 2012). A fundação da COOPERAPAS - Cooperativa Agroecológica dos Produtores Rurais e de Água Limpa da Região Sul de São Paulo - em 2011, cuja missão é

${ }^{19}$ Criado em 2010 pelo Departamento de Agricultura e Abastecimento da Supervisão Geral de Abastecimento da Prefeitura Municipal de São Paulo.

${ }^{20}$ Criado por meio de Decreto Municipal no 51.801/2010 em parceria com o Governo do Estado. 
auxiliar os agricultores em sua organização social e representação, bem como na comercialização de seus produtos, também tem lhes conferido uma maior inserção na sociedade e na política. O Fundo Estadual de Meio Ambiente e Desenvolvimento Sustentável21- (FEMA), cujo recurso destina-se a apoiar projetos que façam uso sustentável dos recursos naturais, manutenção, melhoria e/ou recuperação da qualidade ambiental, pesquisa e atividades ambientais de controle, fiscalização e defesa de meio ambiente, tem beneficiado a região com editais apoiando Organizações Não Governamentais (ONGs) no desenvolvimento da agricultura.

\subsection{O surgimento da APA Bororé-Colônia}

Em 1998 começou o diálogo entre os técnicos da Secretaria do Verde e do Meio Ambiente (SVMA) sobre uma proposta de criação de uma área protegida na região que hoje abriga a APA Bororé-Colônia. Esse diálogo se capilarisou e em 2002, no Seminário Billings ${ }^{22}$, que contou com a participação das comunidades científica e acadêmica, das organizações governamentais e não governamentais, dos representantes empresariais e de movimentos sociais, a região foi apontada para a implantação de uma Área de Proteção Ambiental (ISA, 2003). Logo em seguida, as Oficinas do Plano Regional da Capela do Socorro também reiteraram a indicação da área para a implantação da unidade de conservação (CMSP, 2004).

Em 2003 foi elaborado por Rodrigo Martins dos Santos, na época estagiário da Secretaria do Verde e do Meio Ambiente e aluno do Departamento de Geografia da Faculdade de Filosofia, Letras e Ciências Humanas da Universidade de São Paulo, um estudo com embasamento geográfico que passou a servir de subsídio para a implantação da APA Bororé-Colônia (SANTOS, 2003). Durante o ano de 2004 houve um trabalho conjunto do poder público entre a SVMA e as Subprefeituras de Capela do Socorro e Parelheiros para delimitar os limites da APA, encaminhando ao Conselho Municipal de Meio Ambiente e Desenvolvimento Sustentável (CADES) o relatório preliminar da APA Bororé-Itaim ${ }^{23}$. Dentro do CADES foi criada a Comissão Especial da APA Bororé-Itaim, que em seis reuniões, em um

\footnotetext{
${ }^{21}$ Criado pela Lei no 13.155 de 29/06/2011, com nova disciplina pela Lei no 14.887 de 15/01/2009, vinculado à Secretaria Municipal do Verde e do Meio Ambiente (SVMA).

${ }^{22}$ O Seminário Billings foi organizado em parcerias entre o Poder público e a sociedade civil organizada e teve como objetivo estabelecer um processo de discussão e proposição de ações de recuperação e preservação da Bacia Hidrográfica do Billings.

${ }^{23}$ Esse foi o primeiro nome proposto para a APA Bororé-Colônia.
} 
intervalo de dois meses, emitiu um parecer favorável recomendado ao CADES a aprovação da criação da UC (BERNARDELLI JUNIOR, 2013).

Em seguida, foi redigida a minuta do Projeto de Lei, que, após os caminhos burocráticos percorridos, se converteu em um Projeto de Lei posteriormente submetido à apreciação dos Vereadores da Câmara Municipal (CMSP, 2004). Houve, porém, uma demora na votação deste Projeto de Lei na Câmara Municipal, isso porque supostamente havia entre um grupo de Vereadores a preocupação de que a aprovação da APA pudesse atrasar o início das obras do trecho sul do Rodoanel Metropolitano Mário Covas (RMMC) ${ }^{24}$, cujo processo de licenciamento também se encontrava em andamento (BERNARDELLI JUNIOR, 2013).

A Lei de Criação da APA Bororé-Colônia foi promulgada em 24 de maio de 2006 (Lei no 14.162), após um processo de um ano e seis meses e com a inclusão de dois substitutivos: (1ํ) a mudança do nome para APA Bororé-Colônia e (2ํ) a fragmentação da região da APA em duas porções, passando no meio o Rodoanel Metropolitano Mário Covas, que foi excluído da área da UC (BERNARDELLI JUNIOR, 2013).

\subsection{O trecho sul do Rodoanel Metropolitano Mário Covas}

O contraste e as contradições entre o urbano e o rural são características marcantes e muito presentes na APA Bororé-Colônia. O trecho sul do Rodoanel Metropolitano Mário Covas, obra de grande porte, possui uma relação com a unidade de conservação que se dá tanto por sua inserção na paisagem quanto na história da área protegida. Além de atravessar o território da APABC, como pode ser observado no ANEXO A, seu processo de licenciamento deu-se concomitantemente a criação da UC, entre 1998 e 2004. Essa grande obra de infraestrutura tornou ainda mais complexos os conflitos de natureza variada que já existiam na região (BERNARDELLI JUNIOR, 2013).

Por se tratar de um empreendimento potencialmente causador de impacto ambiental significativo, a Política Nacional de Meio Ambiente (PNMA) ${ }^{25}$ e as Resoluções do Conselho Nacional de Meio Ambiente (Conama) no1/86 e no237/97 exigem que haja o

24 O Rodoanel é um empreendimento viário estatal que objetiva a construção de um anel circulando a metrópole com interligação nas rodovias. O Governo do Estado de São Paulo é o empreendedor do RMMC e a DERSA Desenvolvimento Regional S.A. sua agente executora (GOVERNO DO ESTADO DE SÂO PAULO, 2015).

${ }^{25}$ Lei Federal no 6.938/81. 
licenciamento ambiental de estradas de rodagem com duas ou mais faixas de rolamento. Sendo que sua avaliação fica condicionada a apresentação de um Estudo de Impacto Ambiental (EIA) seguido do Relatório de Impacto Ambiental (RIMA), conforme aponta a Secretaria de Meio Ambiente do Estado de São Paulo (SMA) (SECRETARIA DE TRANSPORTES DO ESTADO DE SÃO PAULO, 2007).

Em outubro de 2004, foi apresentado pela Desenvolvimento Regional S.A (DERSA) à Secretaria de Meio Ambiente do Estado de São Paulo o EIA/RIMA do trecho Sul do Rodoanel Metropolitano Mário Covas para se iniciar o processo de licenciamento (TOGNOLLI, 2006; DERSA, 2005 apud BERNARDELLI JUNIOR, 2013). Segundo a SMA (2004 apud BERNARDELLI JUNIOR, 2013) o traçado deste trecho impactaria remanescentes de Mata Atlântica e campos de várzea que exercem função fundamental na proteção das cabeceiras dos mananciais de abastecimento da Região Metropolitana de São Paulo. Simultaneamente ao processo de licenciamento do RMMC, o Projeto de Lei (PL) 01-0384/2004 propondo a criação da unidade de conservação APA Municipal Bororé-Itaim foi encaminhado.

Há críticas ao processo de licenciamento ambiental do Rodoanel Metropolitano Mário Covas, considerado curto e pouco participativo segundo o Instituto Socioambiental (ISA) e a Secretaria do Verde e do Meio Ambiente (ISA, SVMA; 2005). Também é ressaltado o já conhecido fato de os EIA/RIMA e da Avaliação Ambiental Estratégica (AAE) serem de responsabilidade do proponente, o que acaba por permitir que se tornem instrumentos para ratificar o empreendimento em questão (LABHAB FAU/USP, 2005).

O Rodoanel Metropolitano Mário Covas é uma grande obra, que inevitavelmente causa impactos ambientais. Ainda que haja críticas, a Secretaria do Meio Ambiente do Estado de São Paulo afirma que o EIA e o RIMA foram elaborados permitindo a proposição de medidas mitigadoras e compensatórias para os impactos ambientais gerados (2009). Segundo a SMA (2009, p.10):

Esta é a primeira obra rodoviária com cultura ambiental incorporada na fase de construção. Pela primeira vez, o desempenho ambiental condiciona o pagamento das empreiteiras. Este modelo, que tem demonstrado resultados ambientais importantes, está sendo difundido em outras obras, como nas ampliações da Marginal Tietê e da Jacu-Pêssego.

Vale destacar que a compensação associada a criação de novos parques e o reflorestamento de novas áreas representam um acréscimo de 15 vezes da área que foi suprimida [...] 
Entretanto, muitas expectativas da população foram frustradas com a aprovação do EIA e do RIMA e com a consequente implantação do Rodoanel Metropolitano Mário Covas (BERNARDELLI JUNIOR, 2013). Embora não exista uma modalidade de compensação social contemplada pela legislação que vise atender carências das populações locais, os moradores afetados pela obra em seu trecho sul afirmaram que havia uma expectativa de que o empreendimento pudesse viabilizar através da compensação ambiental atividades de interesse da comunidade, tanto no que diz respeito ao lazer, quanto ao que diz respeito a seu desenvolvimento econômico, mas isso não aconteceu (BERNARDELLI JUNIOR, 2013). As compensações ambientais pelos impactos negativos não mitigáveis do RMMC concentraram-se no plantio compensatório na região e na formação dos Parques Naturais Municipais Jaceguava, Itaim, Bororé e Varginha.

As interferências provocadas pelo processo de licenciamento na tramitação da Lei de criação da APA Bororé-Colônia e outros problemas relatados (supressão de nascentes, assoreamento de corpos d'água, poluição sonora, etc.) com a implantação do trecho sul do Rodoanel Metropolitano Mário Covas constituíram um quadro de injustiça social e ambiental, onde os moradores locais, principalmente aqueles com o referencial mais ligado ao ambiente rural, foram os principais penalizados.

\subsection{O conselho gestor da APA Bororé-Colônia}

A APA Bororé Colônia tem grande potencial de promover a melhoria da qualidade de vida das populações que ali habitam, mas compatibilizar os interesses nessa disputa de poder pelo território para efetivar uma gestão que cumpra seus objetivos é algo complexo e longe de ser facilmente executado. O território da APABC é um cenário de recorrentes conflitos, motivados pelas divergências com relação aos interesses econômicos, socioculturais, assim como os ideais de conservação ambiental traduzidos pelas noções patrimoniais de diferentes atores sociais, como governo, comunidades, organizações não governamentais, empresas, visitantes, pesquisadores e outros. O desafio do diálogo e da participação da sociedade na gestão do patrimônio natural é grande e merece ser pensando em toda sua complexidade, e, no âmbito da APABC, seu conselho gestor é o espaço legitimado para esse movimento. Nas próximas páginas será apresentado o conselho gestor da APABC sem aprofundar a análise neste momento, pois a mesma será feita no capítulo 3. 


\section{A origem, o objetivo, os membros e os conselheiros do conselho gestor da APA Bororé-}

\section{Colônia}

A gestão da APA Bororé-Colônia se dá por meio de um conselho gestor paritário e deliberativo que foi previsto no Capítulo IV da Lei que cria a APABC ${ }^{26}$ (SÃO PAULO, 2006), e seu objetivo é: "promover o gerenciamento participativo e integrado da referida APA às diretrizes das políticas nacional, estadual e municipal de meio ambiente"27 (SÃO PAULO, 2007). O conselho é o espaço legitimado para que os diferentes atores que influenciam e são influenciados pela APABC participem da tomada de decisões sobre a unidade de conservação.

Os membros do conselho são as instituições que o compõe. O conselho gestor da APA Bororé-Colônia é paritário, composto por doze membros do poder público (divididos em oito representantes de entidades do Município e quatro representantes de entidades do Estado) e doze membros da sociedade civil, conforme pode ser observado no quadro 1.

Quadro 1: Membros do conselho gestor da APA Bororé-Colônia.

\begin{tabular}{|c|c|}
\hline $\begin{array}{l}\text { I- a Secretaria Municipal do Verde e do } \\
\text { Meio Ambiente -SVMA }\end{array}$ & XI - a Polícia Militar Ambiental \\
\hline II - a Subprefeitura da Capela do Socorro & $\begin{array}{l}\text { XII - a Empresa Metropolitana de Água e } \\
\text { Energia - EMAE }\end{array}$ \\
\hline III - a Subprefeitura de Parelheiros & $\begin{array}{l}\text { XIII - entidades da sociedade civil e de } \\
\text { fomento para o desenvolvimento } \\
\text { sustentável }\end{array}$ \\
\hline $\begin{array}{l}\text { IV - a Secretaria Municipal de Cultura - } \\
\text { SMC }\end{array}$ & $\begin{array}{l}\text { XIV - OSCIPs ou organizações não } \\
\text { governamentais ligadas à defesa do meio } \\
\text { ambiente }\end{array}$ \\
\hline $\begin{array}{l}\text { V - a Secretaria Municipal da Habitação - } \\
\text { SEHAB }\end{array}$ & $\begin{array}{l}\text { XV - associações de moradores locais de } \\
\text { Bororé, Chácara Santo Amaro, Varginha e } \\
\text { Colônia }\end{array}$ \\
\hline $\begin{array}{l}\text { VI - a Secretaria Municipal de } \\
\text { Planejamento - SEMPLA }\end{array}$ & $\begin{array}{l}\mathrm{XVI}-\text { associações, cooperativas ou } \\
\text { representantes de produtores rurais } \\
\text { atuantes na área }\end{array}$ \\
\hline $\begin{array}{l}\text { VII - a Secretaria Municipal da Saúde - } \\
\text { SMS }\end{array}$ & $\begin{array}{l}\text { XVII - associações de ensino e técnico- } \\
\text { científicas }\end{array}$ \\
\hline $\begin{array}{l}\text { VIII - a Secretaria de Governo Municipal - } \\
\text { SGM/GCM }\end{array}$ & \begin{tabular}{|llll} 
XVIII - cooperativa ou associação de \\
pescadores artesanais
\end{tabular} \\
\hline $\begin{array}{lll}\mathrm{IX}-\mathrm{a} \text { Secretaria } & \text { Estadual de } \\
\text { Ambiente }-\mathrm{SMA} / \mathrm{SP} & & \\
\end{array}$ & $\begin{array}{l}\text { XIX - setor ou associação empresarial } \\
\text { atuante na área da APA Bororé-Colônia }\end{array}$ \\
\hline $\begin{array}{l}\text { X - a Companhia de Saneamento Básico } \\
\text { do Estado de São Paulo - SABESP }\end{array}$ & $\begin{array}{l}\text { XX - associação empresarial de turismo na } \\
\text { área da APA Bororé-Colônia }\end{array}$ \\
\hline
\end{tabular}

Fonte: Lei Municipal no 14.620/2006 (SÃO PAULO, 2006). Organizado pela autora.

\footnotetext{
${ }^{26}$ Lei Municipal no 14.162/2006.

${ }^{27}$ Regimento Interno do Conselho gestor da APA Bororé-Colônia (de acordo com a Lei Municipal 14.162/2006). Artigo 1ㅇ.
} 
As entidades integrantes do poder público devem indicar seus representantes, já as entidades da sociedade civil podem cadastrar seus representantes em um chamamento da Secretaria Executiva do conselho gestor que irá coordenar a eleição destes. Os mandatos têm duração de dois anos ${ }^{28}$. Os representantes podem ser reeleitos ou indicados, no caso do poder público, por uma vez consecutiva. Na ausência de candidatos para a mesma cadeira da sociedade civil, a mesma entidade pode exercer três mandatos, porém deve substituir seu representante quando este atingir quatro anos no conselho.

O conselheiro é quem representa a instituição membro do conselho. No quadro 2, abaixo, estão indicados os atuais conselheiros desta gestão (2013 - 2015) do conselho gestor da APA Bororé-Colônia e os membros do conselho ao qual eles representam.

Quadro 2: Composição do conselho gestor da APA Bororé-Colônia (gestão 2013 - 2015). Continua.

\begin{tabular}{|c|c|}
\hline Poder Público & Sociedade Civil \\
\hline $\begin{array}{l}\text { I - SECRETARIA MUNICIPAL DO VERDE E DO MEIO } \\
\text { AMBIENTE - SVMA } \\
\text { Titular: Alice Maria Calado Melges } \\
\text { Suplente: Débora Gomes Assis }\end{array}$ & $\begin{array}{l}\text { XIII - ENTIDADES DA SOCIEDADE CIVIL E DE FOMENTO PARA } \\
\text { O DESENVOLVIMENTO SUSTENTÁVEL } \\
\text { Titular: Francisco de Paulo Ferreira Almeida Júnior (Micro } \\
\text { Empreendedor Individual - MEI) } \\
\text { Suplente: Gabriela Graça Ferreira (SESC INTERLAGOS) }\end{array}$ \\
\hline $\begin{array}{l}\text { II - SUBPREFEITURA CAPELA DO SOCORRO - SPCS } \\
\text { Titular: Antônio Rodrigues Costa Filho } \\
\text { Suplente: Lozilda da Silva Campos }\end{array}$ & $\begin{array}{l}\text { XIV - OSCIPS OU ORGANIZAÇÕES NÃO-GOVERNAMENTAIS } \\
\text { LIGADAS À DEFESA DO MEIO AMBIENTE } \\
\text { Titular: Luiz Otávio de Alencar Miranda (Instituto de } \\
\text { Tecnologia Social - ITS Brasil) } \\
\text { Suplente: Eduardo Melander Filho (Associação Movimento } \\
\text { Garça Vermelha - MOGAVE) }\end{array}$ \\
\hline $\begin{array}{l}\text { III - SUBPREFEITURA DE PARELHEIROS - SPPA } \\
\text { Titular: Loide Cruz Vidal Parlato } \\
\text { Suplente: Rafael Luiz Guimarães Munhoz }\end{array}$ & $\begin{array}{l}\text { XV - ASSOCIAÇAO DE MORADORES LOCAIS DO BORORÉ } \\
\text { Titular: Anatália Jesus da Rocha Siriano (AMIB - Associação } \\
\text { dos Moradores da llha do } \\
\text { Suplente: Robson Márcio Silveira (AMIB) }\end{array}$ \\
\hline $\begin{array}{l}\text { IV - SECRETARIA MUNICIPAL DE CULTURA - SMC } \\
\text { Titular: Daniele Dionízio dos Santos } \\
\text { Suplente: Carolina Tavares Henriques do Carmo e Silva }\end{array}$ & $\begin{array}{l}\text { XVI - ASSOCIAÇÃO DE MORADORES LOCAIS DA CHÁCARA } \\
\text { SANTO AMARO } \\
\text { Titular: Ezequiel Estanislau de Souza (AMCSA - Associação de } \\
\text { Moradores da Chácara Santo Amaro) } \\
\text { Suplente: Antonio Carlos Pereira Silva (AMCSA) }\end{array}$ \\
\hline $\begin{array}{l}\text { V - SECRETARIA MUNICIPAL DE HABITAÇÃO - SEHAB } \\
\text { Titular: Olga Hypólito } \\
\text { Suplente: Rita de Cássia Corrêa Madureira }\end{array}$ & $\begin{array}{l}\text { XVII - ASSOCIAÇÃO DE MORADORES LOCAIS DO VARGINHA } \\
\text { Titular: Valquíria Cândido da Silva (COOPERPAC - } \\
\text { Cooperativa de Catadores Seletivos do Parque Cocaia) } \\
\text { Suplente: Vanda Bacelar dos Reis (COOPERPAC) }\end{array}$ \\
\hline $\begin{array}{l}\text { VI - SECRETARIA MUNICIPAL DE DESENVOLVIMENTO } \\
\text { URBANO - SMDU } \\
\text { Titular: Olga Maria Soares e Gross } \\
\text { Suplente: Márcia Petrone }\end{array}$ & $\begin{array}{l}\text { XVIII - ASSOCIAÇÃO DE MORADORES LOCAIS DO ITAIM } \\
\text { Titular: Cícero Apóstolo da Silva (Associação Unidos do } \\
\text { Bairro Jardim Bom Clima) } \\
\text { Suplente: Luiz Antonio Katulemburange Amorim (Centro } \\
\text { Cultural Asé Ylê do Hozooane) }\end{array}$ \\
\hline $\begin{array}{l}\text { VII - SECRETARIA MUNICIPAL DE SAÚDE - SMS } \\
\text { Titular: Eduardo de Mais } \\
\text { Suplente: Nanci Aparecida de Matos Toledo }\end{array}$ & 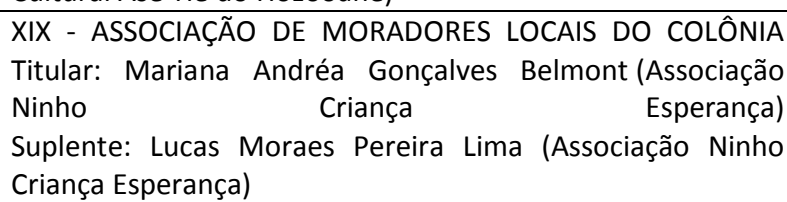 \\
\hline
\end{tabular}

Fonte: Prefeitura Municipal de São Paulo, 2014a.

\footnotetext{
${ }^{28}$ Regimento Interno do Conselho gestor da APA Bororé-Colônia (de acordo com a Lei Municipal 14.162/2006). Artigo 4ㅇ.
} 
Quadro 2: Composição do conselho gestor da APA Bororé-Colônia (gestão 2013 - 2015). Conclusão.

\begin{tabular}{|c|c|}
\hline Poder Público & Sociedade Civil \\
\hline $\begin{array}{l}\text { VIII - SECRETARIA MUNICIPAL DE SEGURANÇA URBANA - } \\
\text { SMSU/GCM } \\
\text { Titular: Richard Soares Mariano } \\
\text { Suplente: Edson Hugo de Andrade Lopes }\end{array}$ & $\begin{array}{l}\text { XX - ASSOCIAÇÕES, COOPERATIVAS OU REPRESENTANTES DE } \\
\text { PRODUTORES RURAIS, ATUANTES NA ÁREA } \\
\text { Titular: Valeria Maria Macoratti (Produtora Rural) } \\
\text { Suplente: VAGO }\end{array}$ \\
\hline $\begin{array}{l}\text { IX - SECRETARIA ESTADUAL DO MEIO AMBIENTE - } \\
\text { SMA/SP } \\
\text { Titular: Marta Emerich } \\
\text { Suplente: Dayane Tarabay }\end{array}$ & $\begin{array}{l}\text { XXI - ASSOCIAÇÕES DE ENSINO E TÉCNICO-CIENTíFICAS } \\
\text { Titular: André Luiz Vieira Barbosa (Associação Cristã de } \\
\text { Ensino) } \\
\text { Suplente: Maria Amparo Del Moral Llobat (Associação } \\
\text { Comunitária Pequeno Príncipe) }\end{array}$ \\
\hline $\begin{array}{l}\text { X - COMPANHIA DE SANEAMENTO BÁSICO DO ESTADO } \\
\text { DE SÃO PAULO - SABESP } \\
\text { Titular: Cintia Elena Nicolau } \\
\text { Suplente: Sidnei Ferreira Ramos }\end{array}$ & $\begin{array}{l}\text { XXII - COOPERATIVA OU ASSOCIAÇÃO DE PESCADORES } \\
\text { ARTESANAIS } \\
\text { Titular: VAGO } \\
\text { Suplente: VAGO }\end{array}$ \\
\hline $\begin{array}{l}\text { XI - POLÍCIA MILITAR AMBIENTAL } \\
\text { Titular: 1o Tenente PM Eduardo Yagima Nishimura Peres } \\
\text { Suplente: Subtenente PM Sebastião Lacerda Barbosa }\end{array}$ & 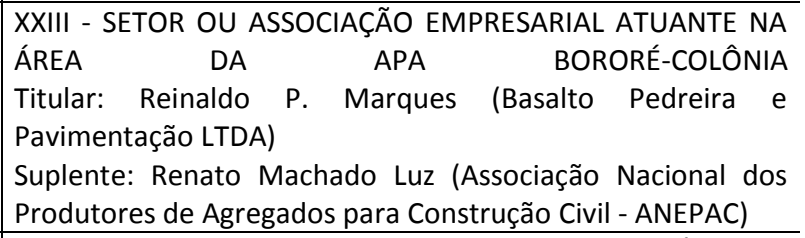 \\
\hline $\begin{array}{l}\text { XII - EMPRESA METROPOLITANA DE ÁGUAS E ENERGIA - } \\
\text { EMAE } \\
\text { Titular: Carlos Eduardo Gomes da Rocha } \\
\text { Suplente: Edgard de Noronha Torrezão }\end{array}$ & $\begin{array}{l}\text { XXIV - ASSOCIAÇÃO EMPRESARIAL DE TURISMO NA ÁREA DA } \\
\text { APA BORORÉ-COLÔNIA } \\
\text { Titular: Sérgio Milani (Associação de Turismo da llha do Boror } \\
\text { ATIBORÉ) } \\
\text { Suplente: Sueli Rocha (ATIBORÉ) }\end{array}$ \\
\hline
\end{tabular}

Fonte: Prefeitura Municipal de São Paulo, 2014a.

Como pode ser observado no quadro 2 , a vaga de suplente na cadeira atribuída as aos produtores rurais atuantes na área, bem como as vagas de conselheiro e suplente na cadeira atribuída aos pescadores artesanais da APA Bororé-Colônia estão vagas. Estes membros do conselho, junto com os representantes das associações de bairro, representam os moradores tradicionais da $\mathrm{APABC}$, aqueles com o referencial mais ligado ao ambiente rural e que devem ser integrados nos processos de gestão ambiental pública, nem que isso demande maiores esforços do poder público. Percebe-se que o conselho deve dedicar força e energia em seu processo de renovação para buscar novos conselheiros.

\section{As reuniões plenárias do conselho gestor da APA Bororé-Colônia}

As plenárias se referem às reuniões que agregam o conjunto dos membros do conselho, são os momentos onde o conselho aperfeiçoa as ideias e as propostas (ICMBIO, 2014). As plenárias permitem compartilhar informações e resultados, tomar decisões coletivas e definir responsabilidades na realização de acordos e atividades definidos pelo grupo de conselheiros (ICMBIO, 2014). 
De acordo com seu Regimento Interno, o conselho gestor da APA Bororé-Colônia deve-se reunir ordinariamente em reunião plenária no mínimo seis vezes ao ano ${ }^{29}$ (SÃO PAULO, 2007). As reuniões do conselho gestor da APABC (figura 7) são abertas à população e atualmente ocorrem na última terça-feira de cada mês, entre as $9 \mathrm{~h} 00$ e as $12 \mathrm{~h} 30$, na Subprefeitura de Capela do Socorro, em uma frequência de onze reuniões anuais. Percebese que as reuniões são intensas e o número de encontros previstos no Regimento Interno não é suficiente para que seja conduzida uma agenda coletiva. Ainda que o conselho tenha graves problemas de participação, discutidos com mais intensidade no capítulo 3 deste trabalho, os encontros são sempre intensos, com muitos assuntos em pauta, e o tempo disponível não é suficiente para atender a quantidade de demandas que o conselho deveria tratar.

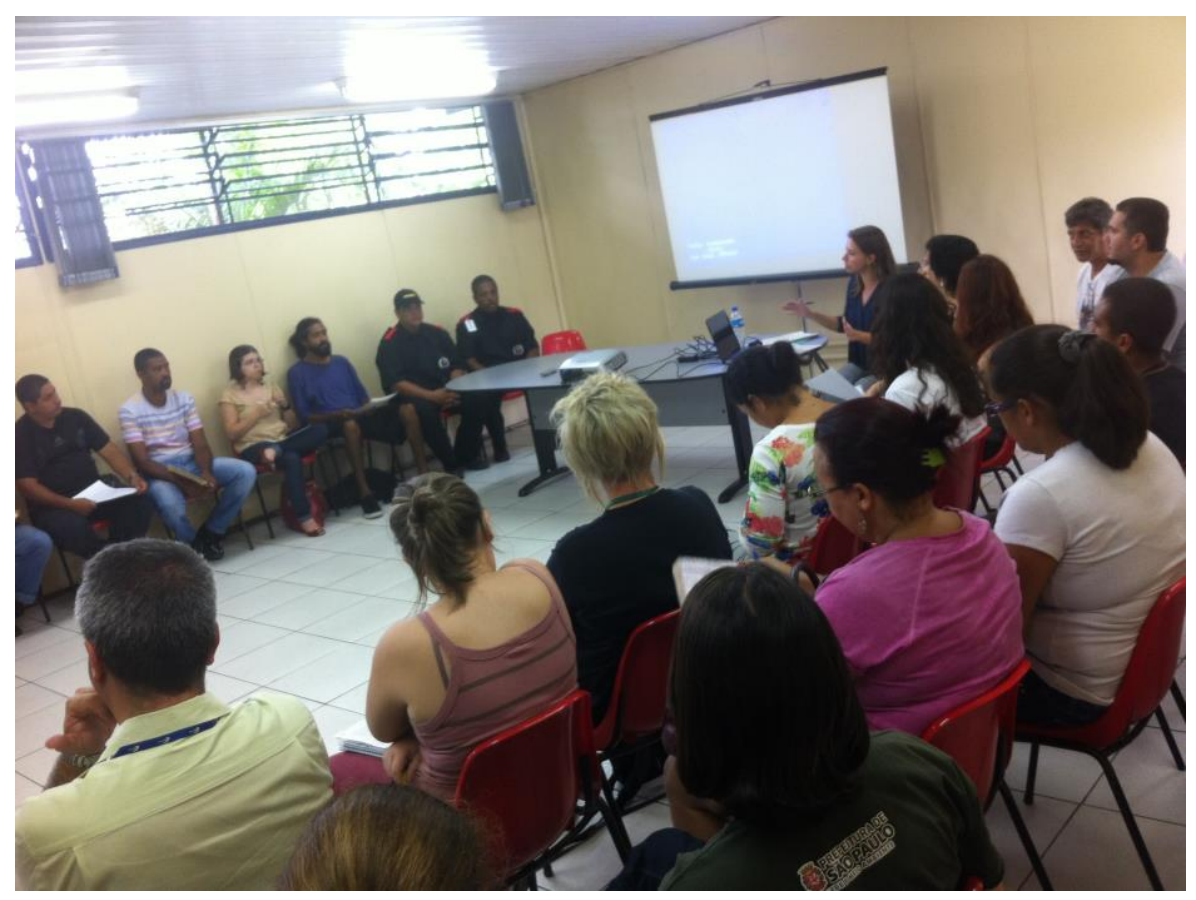

Figura 7 - Reunião Ordinária do conselho gestor da APA Bororé-Colônia.

Fonte: Autora, 2015.

Durante o período de realização da pesquisa as reuniões foram todas na Subprefeitura de Capela do Socorro, em dois lugares diferentes dentro das suas instalações. Este local de realização das reuniões do conselho gestor da APA Bororé-Colônia não pode ser dito de difícil acesso, por estar localizado na zona urbana, mais servida pelo transporte

\footnotetext{
${ }^{29}$ Regimento Interno do Conselho gestor da APA Bororé-Colônia (de acordo com a Lei Municipal 14.162/2006). Artigo 14․
} 
público e pela malha viária. Porém, os conselheiros da sociedade civil que residem nos bairros mais rurais enfrentam grandes dificuldades para acessar a Subprefeitura de Capela do Socorro. O poder público atuante na APA Bororé-Colônia não oferece subsídio algum para que estes conselheiros da sociedade civil possam comparecer nas reuniões. Acredita-se que caberia a Secretaria do Verde e do Meio Ambiente ao menos custear-lhes o deslocamento.

Tal conjuntura demonstra que os representantes do poder público são beneficiados em detrimento dos representantes da sociedade civil. A reunião acontece em um dia útil, na zona mais urbanizada; assim é mais cômodo para os representantes do poder público comparecerem nas reuniões com seus veículos oficiais e em horário de expediente.

Em caso de ausência do representante oficial nas reuniões plenárias, as entidades têm de indicar outro representante ${ }^{30}$, resguardado o limite de quatro indicações ao ano ${ }^{31}$. Os representantes indicados em geral se apresentam apenas ao gestor da APABC e não anunciam aos demais conselheiros sua presença no fórum. Caso o conselheiro titular e o suplente faltem a quatro reuniões ordinárias consecutivas sem justificativa a secretaria executiva, no caso o presidente do conselho gestor da APA Bororé-Colônia, deve solicitar ao membro do conselho que substitua seu(s) representante(s) ${ }^{32}$.

As convocações devem acontecer com antecedência mínima de sete $\operatorname{dias}^{33}$ e as reuniões contam com a presença de no mínimo $25 \%{ }^{34}$ mais um de seus membros para serem instaladas. As reuniões deveriam ser convocadas pela secretaria executiva ${ }^{35}$ do conselho gestor da APA Bororé-Colônia, conforme prevê seu Regimento Interno, porém, na prática, dada a inexistência de um representante para este cargo, as reuniões são organizadas pela presidência do conselho. Cabe à secretaria executiva zelar pela representação dos órgãos e entidades que ocupam as cadeiras de conselheiros, porém, na prática, essa atribuição também acaba ficando a cargo do gestor da APA Bororé-Colônia e

${ }^{30}$ Regimento Interno do Conselho gestor da APA Bororé-Colônia (de acordo com a Lei Municipal 14.162/2006). Artigo 15ㅇ.

${ }^{31}$ Regimento Interno do Conselho gestor da APA Bororé-Colônia (de acordo com a Lei Municipal 14.162/2006). Artigo 25ㅇ.

32 Regimento Interno do Conselho gestor da APA Bororé-Colônia (de acordo com a Lei Municipal 14.162/2006). Artigo 25ㅇ.

${ }^{33}$ Regimento Interno do Conselho gestor da APA Bororé-Colônia (de acordo com a Lei Municipal 14.162/2006). Artigo 17ㅇ.

${ }^{34}$ Regimento Interno do Conselho gestor da APA Bororé-Colônia (de acordo com a Lei Municipal 14.162/2006). Artigo 18․

${ }^{35}$ Regimento Interno do Conselho gestor da APA Bororé-Colônia (de acordo com a Lei Municipal 14.162/2006). Artigo 10․ 
presidente do conselho. A inexistência de um secretário executivo é um indicativo de desinteresse, parece que nenhum conselheiro quer assumir essa atribuição, talvez pela responsabilidade e trabalho que demande.

As deliberações do conselho gestor da APA Bororé-Colônia são tomadas em plenária, por maioria simples dos presentes ${ }^{36}$. O SNUC prevê que fica a critério do conselho gestor definir em seu Regimento Interno quem terá ou não direito a fala. No conselho gestor da APA Bororé-Colônia todo e qualquer cidadão cadastrado antes do início de cada reunião tem direito a voz, mas não tem direito a voto ${ }^{37}$, apenas os conselheiros têm direito a voto (SÃO PAULO, 2007). Ao longo da pesquisa foram observadas poucas situações onde o voto foi utilizado. $\mathrm{O}$ gestor buscou construir com os presentes o melhor caminho a seguir baseado nas argumentações das partes envolvidas, o que é positivo, pois o voto tem muita conotação de vitória e derrota.

Os conselheiros da APA Bororé-Colônia, em geral, atrasam para o início das reuniões; a maior parte começa a chegar por volta das $9 \mathrm{~h} 30$. Como consequência, as reuniões acabam atrasando no mínimo trinta minutos para começar. Como a pauta é longa e há oportunidade de diálogo as reuniões se estendem até por volta das $12 \mathrm{~h} 30$ ou $13 \mathrm{~h} 00$. A falta de compromisso com o horário de início é um demonstrativo de desinteresse e de desrespeito com aqueles que atendem ao horário. Os representantes do poder público normalmente agendam os veículos oficiais para um prazo determinado e, em geral, não podem estender esse período. Então, se a reunião não começa no horário previsto, ela não irá terminar no horário previsto, e, nesta situação, por muitas vezes, alguns representantes do poder público tiveram de se ausentar antes do término da plenária.

\section{A presidência, a secretaria executiva, o assessor técnico e o coordenador da sociedade civil do conselho gestor da APA Bororé-Colônia}

A presidência dos conselhos gestores das unidades de conservação é exercida pelo chefe da UC ou por servidores da instituição gestora, conforme prevê o SNUC ${ }^{38}$ (BRASIL,

\footnotetext{
${ }^{36}$ Regimento Interno do Conselho gestor da APA Bororé-Colônia (de acordo com a Lei Municipal 14.162/2006). Artigo 21ㅇ.

${ }^{37}$ Regimento Interno do Conselho gestor da APA Bororé-Colônia (de acordo com a Lei Municipal 14.162/2006). Artigo 16․

${ }^{38}$ Lei Federal no 9.985/2000.
} 
2000). Atendendo ao disposto na legislação, no conselho gestor da APA Bororé-Colônia a presidência é exercida pelo gestor da referida unidade de conservação e a vice-presidência por outro servidor público da Secretaria do Verde e do Meio Ambiente.

A partir daqui este tópico é marcado pelas ausências. A secretaria executiva do conselho deve ser ocupada por um conselheiro e a escolha desse responsável deve ser feita pelos seus pares conforme prevê o Regimento Interno do conselho gestor da APA BororéColônia ${ }^{39}$. Nos primeiros anos de existência do conselho gestor da APABC essa função foi ocupada por uma conselheira do poder público, porém, atualmente não há um conselheiro que desempenhe essa função, implicando em um acúmulo de funções por parte do gestor e em limitações no andamento das reuniões plenárias do colegiado, conforme apontado no tópico anterior.

O Regimento Interno do conselho gestor da APA Bororé-Colônia também prevê a existência de um conselheiro que ocupe o papel de assessor técnico do conselho ${ }^{40}$. A ele compete fornecer o subsídio de informações para o plenário, para a presidência e para a secretaria executiva do conselho, além de outras atribuições. Porém, na prática, é outra função para a qual não existe um representante incumbido de exercer.

Por fim, a terceira função prevista no Regimento Interno do conselho gestor da APA Bororé-Colônia para a qual não existe um responsável é o coordenador da sociedade civil ${ }^{41}$. Ele deve representar a sociedade civil quando necessário e deliberado pelo plenário do conselho, deve promover reuniões entre os conselheiros da sociedade civil, participar de reuniões externas ao conselho junto ao gestor, entre outras atribuições.

\section{As Câmaras Técnicas e os Grupos de Trabalho do conselho gestor da APA Bororé-Colônia}

As Câmaras Técnicas (figura 8) e os Grupos de Trabalho são criados mediante aprovação de maioria simples dos membros do conselho e consistem em grupos de

\footnotetext{
${ }^{39}$ Regimento Interno do Conselho gestor da APA Bororé-Colônia (de acordo com a Lei Municipal 14.162/2006). Artigo 70.

${ }^{40}$ Regimento Interno do Conselho gestor da APA Bororé-Colônia (de acordo com a Lei Municipal 14.162/2006). Artigo 11․

${ }^{41}$ Regimento Interno do Conselho gestor da APA Bororé-Colônia (de acordo com a Lei Municipal 14.162/2006). Artigo 13․
} 
conselheiros que irão tratar de modo mais específico algumas demandas que estão na agenda do conselho gestor da APA Bororé-Colônia ${ }^{42}$.

Ambos podem contar com a participação de pessoas ou instituições convidadas e a principal diferença entre eles refere-se ao aspecto temporal e a profundidade. Enquanto os Grupos de Trabalho são temporários e se relacionam mais com atividades ligadas ao planejamento e execução das ações previstas no Plano de Ação do conselho, as Câmaras Técnicas são permanentes e objetivam se debruçar de modo mais técnico e profundo para subsidiar as decisões do conselho em assuntos mais complexos.

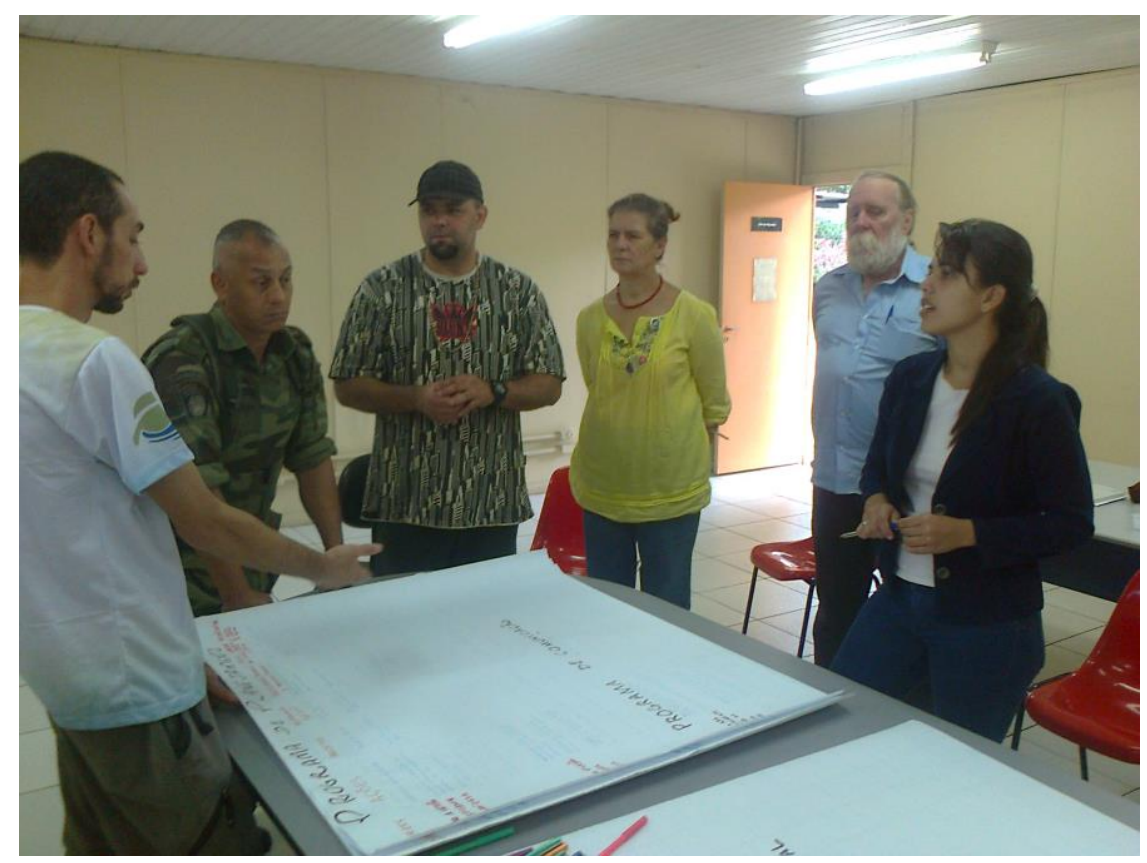

Figura 8 - Reunião da Câmara Técnica de Planejamento e Gestão.

Fonte: Prefeitura Municipal de São Paulo, 2015.

As Câmaras Técnicas e os Grupos de Trabalho permitem uma maior interação entre setores do poder público e da sociedade civil na condução de temas específicos e de conflitos que podem ser amadurecidos antes de serem levados para as reuniões plenárias, e podem contribuir muito para que os trabalhos do conselho sejam mais produtivos. A figura 9, a seguir, foi produzida pelo Instituto Chico Mendes de Biodiversidade (ICMBIO) em uma cartilha denominada "Conselhos Gestores de unidades de conservação federais: um guia para gestores e conselheiros" e ilustra essa relação.

\footnotetext{
42 Regimento Interno do Conselho gestor da APA Bororé-Colônia (de acordo com a Lei Municipal 14.162/2006). Artigos 20 e $3 \circ$.
} 


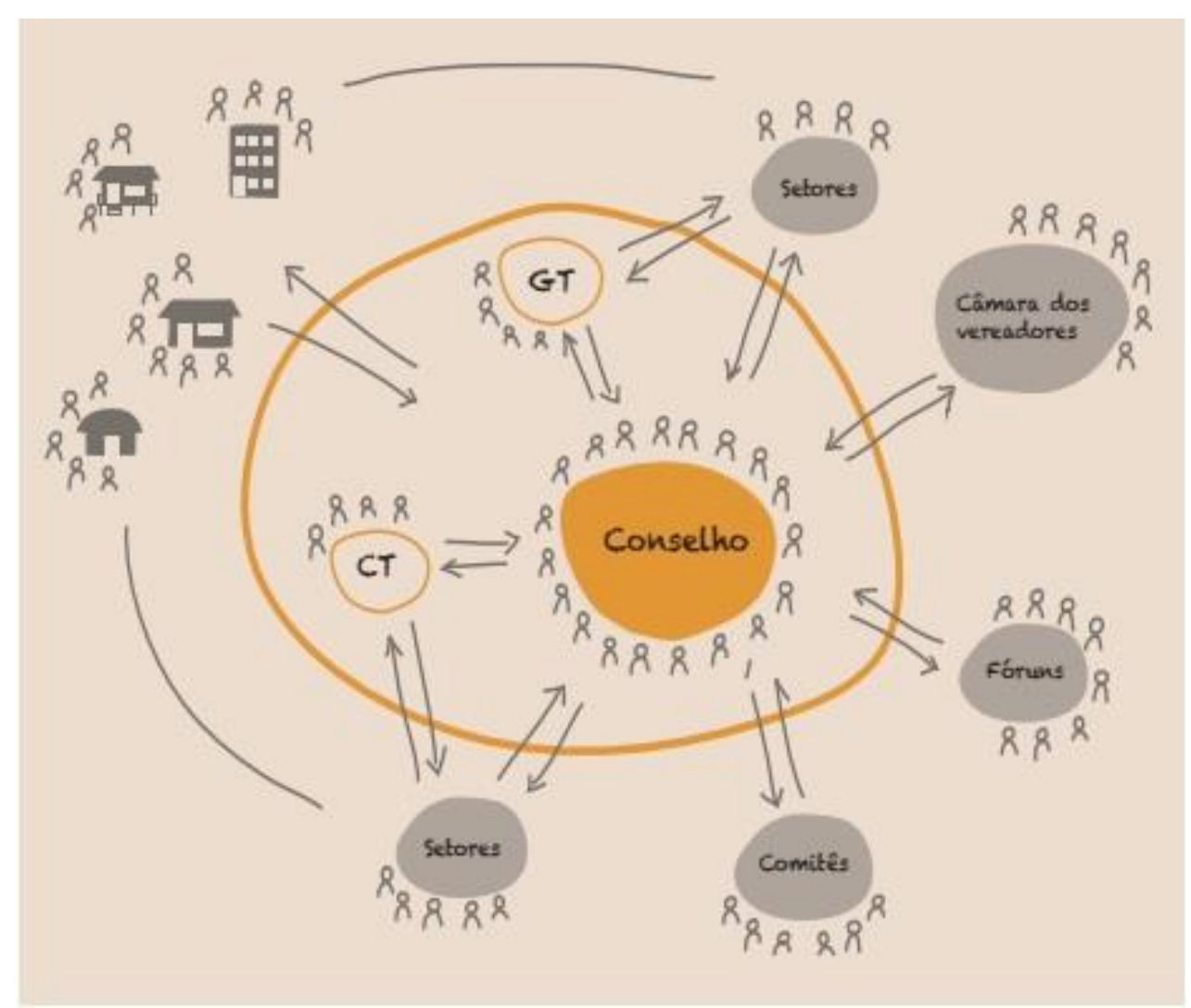

Figura 9 - Interação entre setores do poder público, da sociedade civil, as Câmaras Técnicas, os Grupos de Trabalho e o conselho gestor da unidade de conservação.

Fonte: ICMBIO, 2014.

Mas para que as Câmaras Técnicas e os Grupos de Trabalho possam atuar dessa maneira e com essa considerável autonomia eles precisam de conselheiros capazes, comprometidos e com disponibilidade de empenhar mais recursos (tempo, a princípio) no colegiado. Sem dúvida demanda comprometimento e o tempo pode favorecer o amadurecimento deste movimento.

No quadro 3, a seguir, estão apontados os Grupos de Trabalho e as Câmaras Técnicas previstos para o conselho gestor da APA Bororé-Colônia com base em seu Plano de Ação para a gestão de 2013 e 2015. Ao total, foram propostas seis Câmaras Técnicas, sendo cinco destas em conjunto com o conselho gestor da APA Capivari-Monos, além de quinze Grupos de Trabalho. O número de Grupos de Trabalho é quase três vezes superior ao de Câmaras Técnicas. Isso porque, atualmente, o conselho gestor da APABC está direcionando mais os trabalhos nos Grupos de Trabalho sem intermédio das Câmaras Técnicas. Na prática elas não deixam de existir, mas atuam mais como eixos norteadores dos trabalhos e os representantes são indicados por Grupos de Trabalho e não mais por Câmaras Técnicas como era antes. 
Essa dinâmica parece implicar pouco valor as Câmaras Técnicas, que acabam ficando praticamente inativas, o que acaba por impedir a descentralização do poder e uma maior autonomia dos conselheiros. Sugere-se que sejam retomadas as Câmaras Técnicas e reforçada sua relevância na dinâmica do conselho para que os conselheiros compreendam suas potencialidades e sintam-se interessados em integrá-las.

Quadro 3: Câmaras Técnicas e Grupos de Trabalhos previstos no Plano de Ação do conselho gestor da APA Bororé-Colônia.

\begin{tabular}{c|c} 
Câmaras Técnicas (CT) & Grupos de Trabalho (GT) \\
\hline CT de Planejamento e Gestão & GT de comunicação \\
\hline CT conjunta ${ }^{43}$ de agricultura & GT de educação ambiental \\
\hline CT conjunta de turismo sustentável & GT do Parque Natural Municipal do Itaim \\
\hline CT conjunta de arte e cultura & GT do Parque Natural Municipal do Bororé \\
\hline CT conjunta de fiscalização & GT do Parque Natural Municipal do Varginha \\
\hline CT conjunta de uso do solo & GT manifestações culturais e esportivas \\
\hline Grupos de Trabalho (GT) & GT integrado de patrimônio histórico \\
\hline GT Av. Paulo Guilguer & GT monitoramento comunitário \\
\hline GT Resíduos Sólidos & GT de empreendimentos \\
\hline GT de requalificação socioambiental & GT aeródromo Harpia dos poços da Ilha do Bororé \\
\hline GT integrado de pesquisa científica & GT áto \\
\hline
\end{tabular}

Fonte: PREFEITURA MUNICIPAL DE SÃO PAULO, 2014c.

No Plano de Gestão do conselho gestor da APA Bororé-Colônia, as Câmaras Técnicas e os Grupos de Trabalho são responsáveis por empenhar as ações relacionadas com as diretrizes que compõe os programas de gestão, conforme exemplificado na figura 10, na próxima página. As Câmaras Técnicas e os Grupos de Trabalho do conselho gestor da APA Bororé-Colônia possuem uma agenda de trabalho diretamente relacionada com os objetivos contemplados nos Programas de Ação. Porém, observou-se que, na prática, tanto as Câmaras Técnicas quanto os Grupos de Trabalho dependem muito do gestor da APA BororéColônia para serem fomentados e terem continuidade. Os conselheiros não se apropriaram ainda destas estruturas, eles não as conduzem com relativa autonomia.

${ }^{43}$ As Câmaras Técnicas conjuntas consistem em grupos de conselheiros das APAs Bororé-Colônia e CapivariMonos. 


\begin{tabular}{|c|c|c|c|c|c|c|c|c|c|}
\hline PROGRAMAS & DIRETRUZES & ACOES & PROUETOS & $\begin{array}{l}\text { RESPONSAVEL (GTS, } \\
\text { CTS) }\end{array}$ & PARTCIPANTES MEMDORS) & Parcenros porencials & $\begin{array}{l}\text { Prazo (max. } \\
\text { Sev 2015) }\end{array}$ & 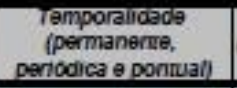 & 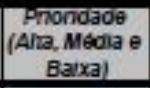 \\
\hline \multirow{9}{*}{ Planejamento } & \multirow{6}{*}{$\begin{array}{l}\text { Tomar a gestio mals } \\
\text { effilente e orgarizada }\end{array}$} & $\begin{array}{l}\text { Elaborar o Plano de } \\
\text { Gestalo }\end{array}$ & Plano de Gestâo & $\begin{array}{l}\text { CT de Planejamento e } \\
\text { Gestato }\end{array}$ & $\begin{array}{l}\text { Diego (SVMA), Anatala (Borore), Rocha } \\
\text { (EMAE), Melander (Mogave), Marcla } \\
\text { (SMDU), Desenvolvimento Sustentavel }\end{array}$ & Conselno Gestor & $\mathrm{ma} / 14$ & Permanente & Alta \\
\hline & & $\begin{array}{l}\text { Acompannar execuçaso } \\
\text { do Plano de Manejoe } \\
\text { Zonearnento Amblentas } \\
\text { da APA }\end{array}$ & $\begin{array}{l}\text { TCA: Plano de Manejo- } \\
\text { USP }\end{array}$ & Duc & - & $\begin{array}{c}\text { Consehno gestor, Geograta } \\
\text { USP (Lab Elo) }\end{array}$ & out $/ 14$ & Pontual & Medla \\
\hline & & $\begin{array}{l}\text { Refomular o formato } \\
\text { da Reurila crolharia }\end{array}$ & - & $\begin{array}{l}\text { CT de Planejamento e } \\
\text { Gestlo }\end{array}$ & $\begin{array}{l}\text { Dlego (SVMA), Anatala (Borore), Rocha } \\
\text { (EMAE). Melander (Mogave), Marcia } \\
\text { (SMDU), Desenvolvimento Sustentavel }\end{array}$ & $\begin{array}{l}\text { Conseho Gestor, Conselho } \\
\text { Gestor da APA Caphart-Mionos }\end{array}$ & set/14 & Pontua & Alta \\
\hline & & $\begin{array}{l}\text { Incentvar a presença e } \\
\text { valonzar a partopaçato } \\
\text { dos conselheros }\end{array}$ & $\begin{array}{l}\text { Dowigaça das acbles } \\
\text { das CTS e GTS no ZSN }\end{array}$ & $\begin{array}{l}\text { CT de Planejamento e } \\
\text { Gestiso }\end{array}$ & $\begin{array}{l}\text { Dlego (SVMA), Anatala (Borore), Rocha } \\
\text { (EMAE), Melander (Mogare), Marcla } \\
\text { (SMDU), Desenvolvmento Sustentavel }\end{array}$ & $\begin{array}{c}\text { Joma Zona Su Notidas, GT } \\
\text { de Comunicaç5o }\end{array}$ & set 15 & Permanente & Alta \\
\hline & & 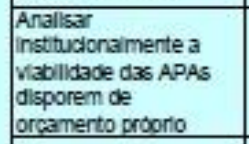 & - & $\begin{array}{l}\text { CT de Planejamento e } \\
\text { Gestoso }\end{array}$ & $\begin{array}{l}\text { Dlego (SVMA), Anatala (Borore), Rocha } \\
\text { (EMAE), Melander (Mogave), Marcla } \\
\text { (SMDU), Desenvolvimento Sustentavel }\end{array}$ & ANSVMMA & set115 & Pontua & Medla \\
\hline & & $\begin{array}{l}\text { Resgatar a Secretaria } \\
\text { Execurtiva }\end{array}$ & - & $\begin{array}{l}\text { CT de Planejamento e } \\
\text { Gestas }\end{array}$ & $\begin{array}{l}\text { Diego (SVMA), Anatalla (Borore), Rocha } \\
\text { (EMAE), Melander (Mogave), Marcla } \\
\text { (SMDU), Desenvolvmento Sustentavel }\end{array}$ & SPCS, SPPA & dez/14 & Pontua & Alta \\
\hline & \multirow{3}{*}{ Cobrar poder publico } & 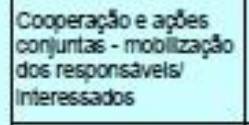 & - & $\begin{array}{l}\text { CT de Planejamento e } \\
\text { Gestà }\end{array}$ & $\begin{array}{l}\text { Dlego (SVMA), Anatala (Borore), Rocha } \\
\text { (EMAE). Meiander (Mogave), Marcla } \\
\text { (SMDU), Desenvolvimento Sustentavel }\end{array}$ & - & set15 & Permanente & Alta \\
\hline & & $\begin{array}{l}\text { Coorar que diterentes } \\
\text { orgás publicos se } \\
\text { apropriem da APA }\end{array}$ & - & $\begin{array}{l}\text { CT de Planejamento e } \\
\text { Gestato }\end{array}$ & $\begin{array}{l}\text { Dlego (SVMA), Anatala (Borore), Rocha } \\
\text { (EMME), Meiander (Mogave), Narcla } \\
\text { (SMDU,), Desenvolvmento Sustentavel }\end{array}$ & GT de Comuricaçäb & dez/14 & Pontua e Permanente & Alta \\
\hline & & $\begin{array}{l}\text { Acompannar } \\
\text { documentasto } \\
\text { encaminhada e coorar } \\
\text { retomo }\end{array}$ & - & $\begin{array}{l}\text { CT de Planejamento e } \\
\text { Gestato }\end{array}$ & $\begin{array}{l}\text { Dlego (SVMA), Anatala (Borore), Rocha } \\
\text { (EMAE), Melander (Mogave), Marcla } \\
\text { (SMDU), Desenvolvmento Sustentavel }\end{array}$ & - & set/15 & Permanente & Medla \\
\hline
\end{tabular}

Figura 10 - Programas de Gestão do Plano de Gestão da APA Bororé-Colônia .

Fonte: PREFEITURA MUNICIPAL DE SÃO PAULO, 2014c. 
A interlocução com os diversos setores do poder público e da sociedade civil deve ser feita e estimulada com transparência e controle coletivo das ações e iniciativas desenvolvidas (ICMBIO, 2014). Sem dúvida é desafiador para as Câmaras Técnicas e Grupos de Trabalho do conselho gestor da APA Bororé-Colônia cumprir com todo o potencial de interlocução, prestação de contas e desempenho que lhe permeiam; o que deixa claro o potencial e longo caminho a seguir, bem como a necessidade de apoio e fomento.

\section{A moderação, a gestão de conflitos e o diálogo}

Durante as reuniões do conselho gestor da APA Bororé-Colônia, o gestor da unidade de conservação e presidente do colegiado exerce grande papel na moderação do encontro. Ele organiza o diálogo, e por conta disso seu perfil e as técnicas por ele dominadas interferem muito na dinâmica das reuniões, possibilitando que todos exponham suas opiniões e construam coletivamente o melhor entendimento naquele momento sobre determinado assunto.

Os conflitos de interesse são naturais, fazem parte da essência do conselho, pois as reuniões são momentos onde diferentes setores que atuam no território da APA BororéColônia se encontram para tratar assuntos sobre os quais não tiveram outras oportunidades de conversar a respeito, e, muitas vezes, esses setores podem possuir posições contrárias, como é frequentemente observado em conselhos gestores de unidades de conservação por todo o país (ICMBIO, 2014). Neste sentido, é muito importante que o gestor, como mediador da reunião, tenha tranquilidade para fazer a gestão dos conflitos e encaminhar as decisões coletivas. A gestão de conflitos intenciona fazer com que as partes envolvidas possam cooperar uma com a outra, sem que uma parte anule a outra, a partir da construção de entendimentos sobre pontos comuns de assuntos tratados de forma que todos se comprometam com a decisão, além de permitir que assuntos mais complexos sejam tratados ao longo do tempo a partir de acordos específicos (ICMBIO, 2014).

Os gestores da APA Bororé-Colônia acompanhados durante a pesquisa ${ }^{44}$ apresentaram postura democrática, empenharam boa gestão de conflitos, sempre estiveram dispostos a promover a participação dos conselheiros e o diálogo. Sempre que possível, e

\footnotetext{
${ }^{44}$ Diego Lustre Gonçalves e Alice Maria Calado Melges.
} 
dependendo da configuração das salas utilizadas, durante as reuniões do conselho gestor da APA Bororé-Colônia as cadeiras são dispostas de forma circular. A intenção é qualificar os diálogos permitindo que todos se olhem, equilibrem suas falas e interajam o máximo possível.

Apesar deste esforço há forte assimetria de poder no conselho, está na mão do gestor a condução da reunião e o fomento à participação dos conselheiros. O conselho gestor da APA Bororé-Colônia pode ter problemas de moderação que levem a uma redução maior ainda na participação dos seus membros caso haja mudança na gestão da unidade de conservação e o novo gestor tenha um perfil fechado à construção coletiva, ou não detenha técnicas para organizar o diálogo.

O gestor da APA Bororé-Colônia geralmente tem feito o uso de metodologia expositiva para conduzir as reuniões do conselho. É interessante que ele utilize também de metodologias participativas, pois elas permitem estimular o compartilhamento de habilidades, conhecimentos e experiências dos participantes; podem criar ambientes acolhedores; facilitar o entendimento sobre algumas questões; contribuem para a tomada de decisão coletiva e para que a reunião alcance seus objetivos (ICMBIO, 2014). Neste sentido, é adequado investir na formação dos gestores das unidades de conservação visando à apropriação de metodologias participativas e de mediação de conflitos para que eles possam deter mais ferramentas que facilitem a condução dos seus trabalhos.

De modo muito interessante, as reuniões das Câmaras Técnicas e dos Grupos de Trabalho do conselho gestor da APA Bororé-Colônia permitem que haja interação entre os conselheiros em ambientes alternativos às reuniões plenárias; como as propriedades rurais dos conselheiros e alguns espaços comunitários ${ }^{45}$. Sugere-se que sejam fomentadas outras oportunidades de interação entre poder público e sociedade civil fora do ambiente da reunião ordinária e até mesmo fora do conselho, pois acredita-se que essas ocasiões podem gerar conhecimentos importantes para qualificar o diálogo nas reuniões.

\footnotetext{
${ }^{45}$ As reuniões das Câmaras Técnicas e Grupos de Trabalho ocorrem fora do ambiente das reuniões ordinárias em espaços itinerantes situados dentro da APABC.
} 


\section{Encaminhamentos nas reuniões ordinárias do conselho gestor da APA Bororé-Colônia}

Ao término da reunião do conselho é importante encaminhar o que deve ser feito, identificando os atores que devem executar a ação e também o período de tempo que ela irá demandar (ICMBIO, 2014). Segundo o Instituto Chico Mendes de Conservação da Biodiversidade, nas unidades de conservação federais, os conselhos podem formalizar seus encaminhamentos e manifestações de três maneiras; a partir de recomendação, de moção e de resolução (ICMBIO, 2014).

A recomendação consiste em um documento orientador aos demais órgãos competentes. A moção trata de um documento que intenciona apresentar uma proposta ou reivindicar uma postura determinada por parte do órgão competente. A resolução é um documento que expressa uma decisão do conselho deliberativo sobre determinado tema de gestão (ICMBIO, 2014). Toda documentação deve ser numerada, datada e registrada em ata com lista de presença devidamente assinada pelos conselheiros (ICMBIO, 2014).

O conselho gestor da APA Bororé-Colônia realiza manifestações e encaminhamentos formalizados que dialogam com os objetivos indicados nos documentos sugeridos pelo Instituto Chico Mendes de Conservação da Biodiversidade, porém, os documentos do conselho gestor da APA Bororé-Colônia não utilizam dessas denominações. Em geral são elaborados pareceres técnicos, ofícios e até e-mails. Considerando o proposto pelo ICMBIO, é interessante que o conselho gestor da APA Bororé-Colônia adote uma padronização de denominação de suas manifestações e encaminhamentos condicionada ao objetivo do documento, bem como seu registro a partir da numeração, da inserção da data, do registro em ata e da disponibilidade do documento em um banco de dados acessado pelos conselheiros.

Após a reunião, também pode ser encaminhado para os conselheiros um documento que sintetize a memória e os encaminhamentos daquele encontro; isto facilita e subsidia o processo dos conselheiros em retornar as informações para os membros que representam (ICMBIO, 2014). Atualmente, com o gestor da APA Bororé-Colônia acumulando as funções do secretário executivo no conselho gestor da unidade de conservação fica difícil de conceber que ele ainda consiga produzir essa memória sintética pós-reunião. Porém, com o apoio de outros conselheiros essa sugestão pode ser implantada e parece ser muito 
relevante para otimizar os encaminhamentos e contribuir nas relações de representação. Afinal, as representações em colegiados não são pessoais, são das instituições, mas os conselheiros tem dificuldade em fazer a ponte entre o fórum e o membro que representam.

\section{O Regimento Interno do conselho gestor da APA Bororé-Colônia}

O Regimento Interno do Conselho Gestor da APA Bororé-Colônia foi publicado em 25/07/2007, cerca de um ano e dois meses após a publicação da Lei Municipal no 14.162 de 24/05/2006 que institui a APA Bororé-Colônia. Não se constatou se esse documento foi construído coletivamente pelos seus membros, porém é possível afirmar que seu texto é simples e facilita a compreensão. Embora reconheça que não exista um modelo ideal de Regimento, o Instituto Chico Mendes de Conservação da Biodiversidade sugere um esquema (figura 9) para representar alguns elementos que auxiliam na composição de um.

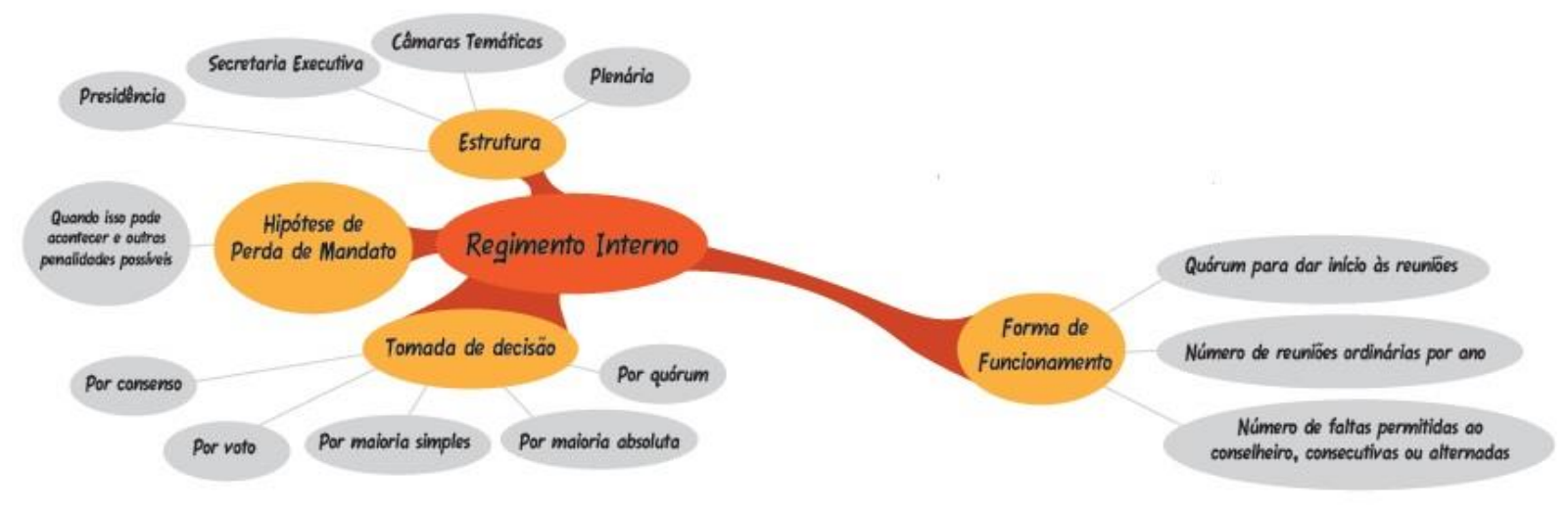

Figura 9 - Conteúdo mínimo que um Regimento Interno de conselhos gestores de unidades de conservação deve conter.

Fonte: ICMBIO, 2014.

Conforme descrito ao longo deste capítulo (1.7.), o Regimento Interno do conselho gestor da APA Bororé-Colônia contem os conteúdos mínimos indicados na figura 9, embora não seja amplamente consultado ou mencionado pelos conselheiros. 


\title{
A educação ambiental no conselho gestor da APA Bororé-Colônia
}

\author{
Segundo o artigo 18o da Lei de Criação da APA Bororé-Colônia ${ }^{46}$
}

[a] implantação da APA Bororé-Colônia será acompanhada de um programa permanente de educação ambiental, que deverá considerar o viés patrimonial, a ser desenvolvido pela Secretaria Municipal do Verde e do Meio Ambiente em parceria com organizações locais da sociedade civil, cuja orientação e acompanhamento caberão ao conselho gestor.

Embora previsto em lei, atualmente não existe um programa de educação ambiental permanente orientado e acompanhando pelo conselho gestor da APA Bororé-Colônia. O assunto é tratado por um Grupo de Trabalho, que tem caráter temporário, e não por uma Câmara Técnica, com características mais perenes. A este entendimento se aponta uma crítica, pois a educação ambiental deve ser compreendida como um processo, não como ações pontuais. Merece ser tratada como um assunto complexo, que demanda o amadurecimento a partir da construção coletiva de um grupo de conselheiros que se reúnam frequentemente para pensá-la, no caso uma Câmara Técnica.

O Plano de Gestão da APA Bororé Colônia, desenvolvido pela Câmara Técnica de Planejamento e Gestão, indica a educação ambiental como um de seus programas de ação, e sua diretriz consiste em conscientizar a população para o desenvolvimento sustentável. No documento, a UMAPAZ ${ }^{47}$ é indicada como a entidade parceira para executar as seguintes ações contempladas dentro do programa: planejamento de cursos, oficinas e campanhas educativas; realização de campanhas de sensibilização em locais críticos; articular ações e projetos da APABC com os Parques Naturais Municipais Jaceguava, Itaim, Bororé e Varginha; acompanhar a elaboração e implantação dos Programas de Educação Ambiental dos PNMs Jaceguava, Itaim, Bororé e Varginha; participar dos fóruns de discussão da região e estudar formas de vincular com os trabalhos da APABC; participação de conselheiros no curso de gestão pública socioambiental; capacitação de moradores para serem multiplicadores das ações; fortalecimento dos atores já existentes; mapeamento/ levantamento de espaços para abordagens de cunho educativo e ambiental.

\footnotetext{
${ }^{46}$ Lei Municipal no 14.162/2006.

47 A UMAPAZ faz parte do Departamento de Educação Ambiental da Secretaria Municipal do Verde e do Meio Ambiente da Prefeitura do Município de São Paulo e opera por meio de uma rede de parcerias.
} 
O programa de educação ambiental dentro do Plano de Ação do conselho gestor da APA Bororé-Colônia é quase que totalmente direcionado aos moradores da unidade de conservação, e não aos conselheiros. Sem dúvida é fundamental que a educação ambiental tenha como público alvo a comunidade residente na $A P A B C$, mas o programa de educação ambiental tem grande potencial para trabalhar no fortalecimento da governança no conselho gestor da APA Bororé-Colônia, os conselheiros não podem ser relegados para o segundo plano. Há de se mencionar que, atualmente, existem ações voltadas para o conselho. São oferecidas vagas para os conselheiros em cursos promovidos pela UMAPAZ ${ }^{48}$ em temas que contribuem para sua formação. Porém, se faz uma crítica a esses cursos em três aspectos: (1ํ) os conselheiros não são envolvidos na elaboração das propostas desses cursos, ou seja, esses cursos foram pensados pela UMAPAZ e os temas não foram efetivamente solicitados pelos conselheiros; (2ํ) não há uma avaliação se esses cursos trouxeram contribuições para os conselheiros e para o conselho, se há os dados não são divulgados no conselho gestor da APABC para serem utilizados no seu monitoramento; e (3으) não há um empenho do poder público para facilitar a participação dos conselheiros, principalmente aqueles moradores dos bairros rurais, como a oferta de transporte, ou a realização do curso nos bairros rurais ${ }^{49}$.

Sugere-se que o programa de educação ambiental permanente previsto em lei seja implantado, de modo que sua orientação e acompanhamento se dê pela Câmara Técnica de Educação Ambiental a ser instituída no conselho gestor da APA Bororé-Colônia. O programa de educação ambiental deve empenhar projetos que contemplem como público-alvo o gestor, os conselheiros e os moradores da unidade de conservação, é claro que apoiado em diferentes abordagens. Segundo a Lei de criação da APA Bororé-Colônia, os recursos para a implantação desse programa podem ser oriundos das infrações ambientais ${ }^{50}$, além das provisões advindas da Secretaria Municipal do Verde e do Meio Ambiente.

\footnotetext{
48 A UMAPAZ oportuniza com frequência vagas em cursos que contribuem na formação dos conselheiros. Durante a pesquisa, nas reuniões do conselho foram oferecidas vagas no 2 o Curso de Meio Ambiente do Conselho para as APAs Bororé-Colônia e Capivari-Monos, no minicurso Conhecendo as responsabilidades por ações lesivas ao meio ambiente, no Curso de Legislação Ambiental e Fiscalização em Áreas Protegidas e no Curso de Gestão Pública Socioambiental: Instrumentos de Políticas Urbanas e Aplicações na Região Sul da Cidade - Macrosul.

49 Os cursos listados acima ocorreram na zona urbana.

${ }^{50}$ Lei Municipal no 14.162/2006. Artigo 31ㅇ․
} 
É importante mencionar que, de acordo com a bibliografia, o termo educação ambiental foi utilizado pela primeira vez em 1965, na Conferência em Educação promovida pela Universidade de Keele, na Grã-Bretanha, e com o passar dos anos emergiram diferentes denominações e classificações para expor as práticas e reflexões relacionadas com o tema. Neste sentido, é importante que haja entendimento por parte do conselho gestor da APA Bororé-Colônia sobre a corrente de pensamento com a qual o programa de educação ambiental se relaciona. Diversos autores conduziram importantes estudos sobre o tema da educação ambiental, e tomando como base o proposto por Loureiro (2006) a educação ambiental pode ser enquadrada em duas correntes de pensamentos: o bloco conservador ou comportamentalista e o bloco transformador, crítico ou emancipatório. As características de ambos estão reunidas no quadro 4, na próxima página.

A natureza é indissociável do ser humano e vice-versa, a questão ambiental diz respeito aos problemas relativos à conservação ambiental e a melhoria da qualidade de vida das comunidades, estes, por sua vez, são frutos dos modos pelos quais a sociedade se relaciona com o meio natural (QUINTAS, 2000). Neste sentido, sugere-se que as propostas de educação ambiental do conselho gestor da APA Bororé-Colônia sejam concebidas tendo como referencial o bloco transformador, crítico ou emancipatório (LOUREIRO, 2006). 
Quadro 4: Diferenças entre os blocos conservador ou compormentalista e o bloco transformador, crítico ou emancipatório no cenário da educação ambiental.

\begin{tabular}{|c|c|}
\hline Bloco conservador ou compormentalista & Bloco transformador, crítico ou emancipatório \\
\hline $\begin{array}{l}\text { Compreensão naturalista e conservacionista da } \\
\text { crise ambiental. }\end{array}$ & $\begin{array}{l}\text { Busca da realização de autonomia e liberdades } \\
\text { humanas em sociedade, redefinindo o modo } \\
\text { como nos relacionamos com a nossa espécie, com } \\
\text { as demais espécies e com o planeta. }\end{array}$ \\
\hline $\begin{array}{l}\text { Educação entendida em sua dimensão individual, } \\
\text { baseada em vivências práticas. }\end{array}$ & $\begin{array}{c}\text { Politização e publicização da problemática } \\
\text { ambiental em sua complexidade. }\end{array}$ \\
\hline $\begin{array}{c}\text { Despolitização do fazer educativo ambiental, } \\
\text { apoiando-se em pedagogias comportamentalistas } \\
\text { ou alternativas de cunho místico. }\end{array}$ & $\begin{array}{c}\text { Convicção de que a participação social e o } \\
\text { exercício da cidadania são práticas indissociáveis } \\
\text { da educação ambiental. }\end{array}$ \\
\hline $\begin{array}{l}\text { Baixa problematização da realidade e pouca } \\
\text { ênfase em processos históricos. }\end{array}$ & $\begin{array}{l}\text { Preocupação concreta em estimular o debate e o } \\
\text { diálogo entre ciências e cultura popular, } \\
\text { redefinindo objetos de estudo e saberes. }\end{array}$ \\
\hline $\begin{array}{l}\text { Baixa problematização da realidade e pouca } \\
\text { ênfase em processos históricos. }\end{array}$ & $\begin{array}{l}\text { Indissociação no entendimento de processos } \\
\text { como: produção e consumo; ética, tecnologia e } \\
\text { contexto sócio-histórico; interesses privados e } \\
\text { interesses públicos. }\end{array}$ \\
\hline $\begin{array}{l}\text { Diluição da dimensão social na natural, faltando } \\
\text { entendimento dialético da relação sociedade- } \\
\text { natureza (sociedade como realização coletiva e } \\
\text { objetivada da natureza humana, ou melhor, como } \\
\text { realização e exigência para a sobrevivência da } \\
\text { espécie humana - MORIN, 2002b apud } \\
\text { LOUREIRO, 2006). }\end{array}$ & $\begin{array}{l}\text { Busca de ruptura e transformação dos valores e } \\
\text { das práticas sociais contrários ao bem-estar } \\
\text { público, à eqüidade e à solidariedade. }\end{array}$ \\
\hline $\begin{array}{l}\text { Responsabilização pela degradação posta em um } \\
\text { homem genérico, fora da História, } \\
\text { descontextualizado social e politicamente. }\end{array}$ & \\
\hline
\end{tabular}

Fonte: Loureiro, 2006, p.133 e 134. Organizado pela autora.

Quando se considera a realidade brasileira, "entre as potencialidades dos conselhos e sua efetividade na formulação e controles dessas políticas, há uma longa distância a ser percorrida" (CARNEIRO, 2002). O conselho gestor da APA Bororé-Colônia, diante da diversidade de atores presentes no território da $A P A B C$, dos interesses que convergem para a região e da realidade das instâncias irmãs no País, precisa superar muitos obstáculos para fortalecer a governança, pois sua missão é complexa. Neste sentido, este capítulo apenas apresentou o conselho gestor da APABC, adiante, no capítulo 3, será aprofundada a análise sobre o conselho tendo como pano de fundo sua governança. 


\subsection{As demais unidades de conservação do extremo sul do município de São Paulo}

No extremo sul do município de São Paulo existe um mosaico ${ }^{51}$ de unidades de conservação, ainda que não institucionalizado. Além da APA Bororé-Colônia há ali mais sete unidades de conservação: O Parque Estadual da Serra do Mar (PESM), a Área de Proteção Ambiental Capivari-Monos (APA Capivari-Monos) e os Parques Naturais Municipais Jaceguava, Itaim, Bororé, Varginha e Cratera de Colônia.

A APA Bororé-Colônia, parte da APA Capivari-Monos e os Parques Naturais Municipais Itaim, Bororé, Varginha e Cratera de Colônia podem ser observados no ANEXO A.

\subsubsection{Parque Estadual da Serra do Mar}

O Parque Estadual da Serra do Mar é o maior Parque do Estado de São Paulo, abrangendo mais de 315.000 hectares e trinta e nove municípios. Uma de suas funções é ser um corredor biológico de Mata Atlântica. Para facilitar sua gestão, o Parque é dividido em dez núcleos administrativos (FUNDAÇÃO FLORESTAL, 2014a).

O núcleo Curucutu do PESM, com pouco mais de 37.000 hectares, abrange os municípios de São Paulo, Itanhaém, Juquitiba e Mongaguá. Cerca de 4.500 hectares deste núcleo se sobrepõe à APA Capivari-Monos, fazendo com que essa APA atue como uma zona de amortecimento para o Parque, organizando e orientando os tipos de uso no entorno do PESM (PREFEITURA MUNICIPAL DE SÃO PAULO, 2012).

O núcleo Curucutu tem sua história calcada na preservação do manancial do extremo sul do município de São Paulo. Ele foi criado em 1958 a partir da antiga Fazenda Curucutu, produtora de carvão vegetal. Em 1960, pelo Decreto Estadual no 36.544, a área foi transformada em Reserva Florestal com a intenção de garantir a integridade física do local e desenvolver pesquisas que objetivavam a recuperação da área desflorestada. Na década de 1970, por meio do Decreto Estadual no $10.251 / 77$ foi criado o PESM $^{52}$ e o Núcleo Curucutu foi incorporado ao Parque (FUNDAÇÃO FLORESTAL, 2014b).

\footnotetext{
51 Mosaico é "um conjunto de unidades de conservação de categorias diferentes ou não, próximas, justapostas ou sobrepostas, e outras áreas protegidas públicas ou privadas" cuja gestão deve ser feita de maneira conjunta e integrada (Lei Federal no 9.985/200. Artigo 26ㅇ).

${ }^{52}$ Ampliado pelos decretos no 13.313, de 06/03/79 e no 19.448, de 30/08/82 (FUNDAÇÃO FLORESTAL, 2014).
} 
A gestão do Parque Estadual da Serra do Mar cabe a Fundação Florestal (FF), órgão vinculado à Secretaria do Meio Ambiente do Estado de São Paulo (SMA). Sem dúvida esse é um dos Parques de maior visibilidade no Estado e a FF acumula uma longa expertise na gestão de unidades de conservação.

\subsection{2. Área de Proteção Ambiental Capivari-Monos}

A APA Capivari-Monos possui uma área de $251 \mathrm{~km}^{2}$ e é a primeira APA Municipal de São Paulo. Foi criada em 2001, pela Lei Municipal no 13.706/2001, e está situada na Subprefeitura de Parelheiros (PREFEITURA MUNICIPAL DE SÃO PAULO, 2015b). Após dez anos de implantação teve aprovado o seu Plano de Manejo em 2011. A APA Capivari-Monos inovou na concepção da participação social na gestão ambiental pública, pois instituiu, em 2002, o primeiro conselho gestor de APA do Estado de São Paulo deliberativo e paritário entre sociedade civil e poder público em sua composição. A presidência do conselho cabe a Secretaria do Verde e do Meio Ambiente, que é seu órgão gestor e os mandatos duram dois anos (PREFEITURA MUNICIPAL DE SÃO PAULO, 2015b).

Assim como a APA Bororé-Colônia, a APA Capivari-Monos possui uma paisagem que remete ao ambiente rural. Em seu território localizam-se duas aldeias indígenas Guaranis (os Tenondé-Porã e os Krukutus), pequenos agricultores, atrativos naturais como cachoeiras e rios cristalinos, fragmentos florestais que abrigam diversas espécies animais e vegetais, incluindo alguns mamíferos de grande porte como a onça-parda (Puma concolor capricorniensis) e a anta (Tapirus terrestris) (PREFEITURA MUNICIPAL DE SÃO PAULO, 2015b).

O contexto histórico da APA Capivari-Monos é semelhante ao da APA Bororé-Colônia; a Vila Ferroviária e a Estação de Evangelista de Souza (inaugurada em 1936) são marcas no território que remetem a esse passado recente do início do século XX. Porém, quando olhamos para um passado mais longínquo, houve um fato muito específico no território da APA Capivari-Monos. Há cerca de vinte milhões de anos atrás, a região desta unidade de conservação foi impactada por um meteoro de estimados duzentos metros de diâmetro que formou uma cratera de cerca de 3,6 km de diâmetro, chamada Cratera de Colônia, tombada 
pelo Condephaat como patrimônio natural, onde foi estabelecido o Parque Natural Municipal Cratera de Colônia 53 .

\subsubsection{Parques Naturais Municipais Jaceguava, Itaim, Bororé e Varginha}

A criação dos Parques Naturais Municipais Jaceguava, Itaim, Bororé e Varginha é fruto da compensação ambiental referente ao licenciamento do trecho sul do Rodoanel Metropolitano Mário Covas. Segundo a Prefeitura Municipal de São Paulo:

Estes Parques Naturais Municipais (PNMs) devem contribuir com a compensação de impactos ambientais negativos causados pelas obras do Rodoanel sobre fragmentos florestais de Mata Atlântica, assim como sobre várzeas da região, que estão inseridos na Área de Proteção aos Mananciais Billings e Guarapiranga e na Reserva da Biosfera do Cinturão Verde de São Paulo. Também devem promover a integração da comunidade por meio do desenvolvimento de programas e projetos que visem a inclusão social dessas populações, além da conservação da fauna, da flora e dos processos ecológicos atrelados a eles, principal objetivo destes PNMs. (PREFEITURA MUNICIPAL DE SÃO PAULO, 2014d, 2014e, 2014f, 2014g).

Os Parques estão localizados em uma importante região produtora de água e compreendem importantes fragmentos florestais. Eles estão inseridos em uma faixa de transição entre a frente de expansão urbana do distrito do Grajaú e as áreas mais preservadas do extremo sul da cidade de São Paulo. Possuem características ambientais relevantes, e têm o potencial para serem redutos de lazer e local de contato com a natureza para a sociedade carente que o circunda. No quadro 5, a seguir, constam dados sobre a área, a subprefeitura e o decreto de criação de cada Parque.

\footnotetext{
53 Decreto Municipal no 48.423/2007.
} 
Quadro 51: Dados sobre os Parques Naturais Municipais Jaceguava, Itaim, Bororé e Varginha.

\begin{tabular}{c|c|c|c}
\cline { 2 - 4 } & Área & $\begin{array}{c}\text { Inserido na } \\
\text { Subprefeitura }\end{array}$ & Decreto de Criação \\
\hline $\begin{array}{c}\text { Parque Natural } \\
\text { Municipal Jaceguava }\end{array}$ & 276 hectares & Parelheiros & $\begin{array}{c}\text { Decreto no 52.974, de 14 de } \\
\text { fevereiro de 2014 } \\
\text { (SÃO PAULO, 2014) }\end{array}$ \\
\hline $\begin{array}{c}\text { Parque Natural } \\
\text { Municipal Itaim }\end{array}$ & 479 hectares & Parelheiros & $\begin{array}{c}\text { Decreto no 53.227, de 20 de } \\
\text { junho de 2014 } \\
\text { (SÃO PAULO, 2014) }\end{array}$ \\
\hline $\begin{array}{c}\text { Parque Natural } \\
\text { Municipal Bororé }\end{array}$ & 170 hectares & Capela do Socorro & $\begin{array}{c}\text { Decreto no 52.972, de 14 de } \\
\text { fevereiro de 2014 } \\
\text { (SÃO PAULO, 2014) }\end{array}$ \\
\hline $\begin{array}{c}\text { Parque Natural } \\
\text { Municipal Varginha }\end{array}$ & 338 hectares & Capela do Socorro & $\begin{array}{c}\text { Decreto no 52.973, de 14 de } \\
\text { fevereiro de 2014 } \\
\text { (SÃO PAULO, 2014) }\end{array}$ \\
\hline
\end{tabular}

Fonte: PREFEITURA MUNICIPAL DE SÃO PAULO, 2014d, 2014e, 2014f, 2014g. Organizado pela autora.

A gestão e administração dos Parques, assim como a das APA, cabem a Secretaria Municipal do Verde e do Meio Ambiente, por meio do Departamento de Parques e Áreas Verdes - DEPAVE (SÃO PAULO, 2012). Os referidos Decretos citados no quadro 5 preveem que cada Parque disponha de um conselho consultivo, presidido pela instituição gestora e constituído por órgãos públicos e organizações da sociedade civil, conforme indica o Sistema Nacional de Unidades de Conservação (LEI FEDERAL no 9.985, 2000). Porém, até a conclusão deste estudo, estes Conselhos ainda não haviam sido constituídos, sendo o conselho gestor da APA Bororé-Colônia o fórum de participação social na gestão destas UCs (PREFEITURA MUNICIPAL DE SÃO PAULO, 2014d, 2014e, 2014f, 2014g).

Como pode ser observado no ANEXO A, os Parques Naturais Municipais Itaim, Bororé e Varginha (figura 10) estão sobrepostos a APA Bororé-Colônia, enquanto que o Parque Natural Municipal Jaceguava é seu vizinho. Os Decretos de criação dos Parques também consideram essa sobreposição ${ }^{54}$ :

$\S$ 2‥ De forma a compatibilizar a justaposição e sobreposição de unidades de conservação de categorias diferentes, a gestão deverá se realizar de forma integrada e participativa, constituindo mosaico de unidades, conforme previsto no artigo 26 da Lei Federal no 9.985, de 2000.

Os referidos Decretos também preveem que os Parques tenham um Plano de Manejo ${ }^{55}$ :

\footnotetext{
54 Decretos no 52.972/2012, n으 52.973/2012 e no 52.974. Artigo 3‥ Parágrafo 2ㅇ․

55 Decretos no 52.972/2012, no 52.973/2012 e no 52.974. Artigo 4ㅇ․
} 
“Art. 4․ O Plano de Manejo do Parque Natural Municipal Jaceguava/Itaim/Bororé/Varginha deverá ser elaborado sob a coordenação do DEPAVE, no prazo de 180 (cento e oitenta) dias, contados da data de publicação deste decreto.

$\S 1$ 1‥ A elaboração do Plano de Manejo seguirá as disposições definidas pelo Sistema Nacional de Unidades de Conservação da Natureza - SNUC, instituído pela Lei Federal no 9.985, de 2000, regulamentada pelo Decreto Federal no 4.340, de 2002, além da metodologia proposta pelo Instituto Brasileiro do Meio Ambiente e dos Recursos Naturais Renováveis - IBAMA. $\S 2$ 2․ Até que o Plano de Manejo seja aprovado serão permitidas apenas as atividades necessárias à implantação de infraestrutura no Parque ora criado, bem como pesquisas autorizadas pelo DEPAVE.

Os estudos e levantamentos para os Planos de Manejo dos Parques Naturais Municipais Jaceguava, Itaim, Bororé e Varginha foram realizados a partir de um convênio entre a Desenvolvimento Rodoviário S/A (contratante) e o Departamento de Geografia da Faculdade de Filosofia, Letras e Ciências Humanas da Universidade de São Paulo (contratada). No entanto, até junho de 2015 os relatórios preliminares dos Planos de Manejo não haviam sido aprovados pela Secretaria do Verde e do Meio Ambiente (órgão gestor das UCS) e pela DERSA, etapa que precede a consulta pública para a aprovação dos documentos.

Os objetivos de gestão da unidade de conservação da categoria Parque vão além da conservação dos recursos que a unidade protege, abarcam também a realização de pesquisas científicas e o desenvolvimento de atividades de educação e interpretação ambiental, de recreação e de turismo ecológico ${ }^{56}$. Entretanto, os Parques Naturais Municipais permanecem com seus portões fechados ao público, salvo na realização de eventos pontuais previamente organizados com a Secretaria do Verde e do Meio Ambiente. Contudo, o uso "clandestino" para nadar, pescar, caminhar e contemplar a natureza continua acontecendo, conforme observado nas incursões a campo.

As ausências de Plano de Manejo, de recursos humanos e financeiros são grandes entraves para a abertura dos Parques Naturais Municipais. O poder público deveria assumir essas unidades de conservação, de nada adianta a criação desses espaços como medida de compensação ambiental se seus objetivos de gestão já estão comprometidos desde o primeiro dia de sua existência. Os Parques são uma grande oportunidade de oferta de lazer e

\footnotetext{
${ }^{56}$ Lei Federal no 9.985/2000. Artigo 11ㅇ․
} 
potenciais promotores da educação ambiental, carências das comunidades locais, além de conservarem importantes remanescentes florestais.

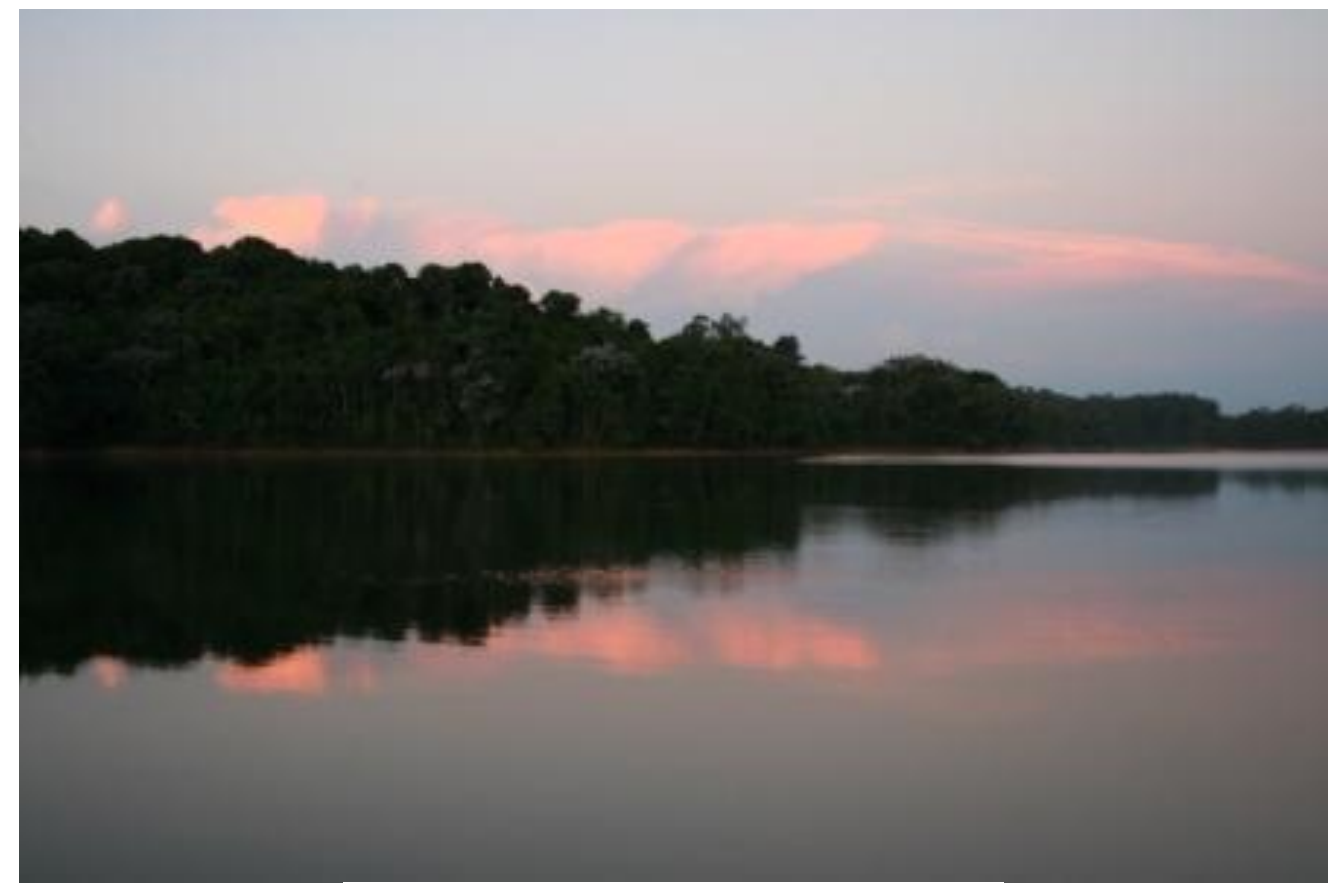

Figura 10 - Parque Natural Municipal Varginha Fonte: PREFEITURA MUNICIPAL DE SÃO PAULO, 2015. 


\section{CAPÍTULO 2}

\section{Quadro referencial conceitual e teórico}

Este capítulo tem como objetivo apresentar as bases teóricas e conceituais que embasaram o desenvolvimento da dissertação. Inicia-se pela apresentação dos conceitos de território, sua relação com o poder e com a territorialidade. Em seguida, trata do Sistema Nacional de Unidades de Conservação e suas interfaces com a participação social. O capítulo se estende pela conceituação da governança, e mais, o que seria uma "boa" governança na gestão de áreas naturais protegidas. Para finalizar, são abordados aspectos das políticas públicas que afetam a governança em conselhos gestores de unidades de conservação.

\subsection{0 território e as relações de poder}

O extremo sul do município de São Paulo, como foi apontado, possui características rurais e uma população voltada para a metrópole, configurando um cenário com especificidades quando comparado às demais regiões da cidade. Considerar a composição do território, dos atores sociais atuantes e das relações de poder estabelecidas é importante para situar o olhar sobre a governança do conselho gestor da APA Bororé-Colônia.

Do ponto de vista político-econômico, o extremo sul é o abrigo para uma população mais pobre, que com a expansão da metrópole foi expulsa para as áreas de mananciais. Sob uma perspectiva político-social, essas pessoas entram em conflito com o governo para terem acesso aos serviços considerados essenciais para a sua mínima qualidade de vida, serviços estes que muitas vezes são característicos das cidades e escassos nas periferias. Essa população é acometida por um processo de perda de seus referenciais do mundo rural em substituição a uma representação urbana caótica. Do ponto de vista natural, a área da APA Bororé-Colônia e seu entorno é uma região de mananciais extremamente importantes para a manutenção de água, e no ano de 2014 os reservatórios de água da cidade de São Paulo se encontravam com índices muito baixos (SABESP, 2014).

Diferentes disciplinas, como Antropologia, Economia, Etologia, Geografia, Ciências Políticas, entre outras, fizeram uso do conceito território, sob diferentes abordagens, para 
explicar seus objetos de pesquisa. A maior parte destes entendimentos, entretanto, trata o território de um ponto de vista setorial, que é fragmentado, por meio de abordagens "unidimensionais" (HAESBAERT, 2004). Neste estudo, procura-se entender o território em uma abordagem mais interdisciplinar, pois percebe-se, com o que foi colocado sobre o extremo sul de São Paulo, que há diferentes dimensões sociais, de representação e de interação da sociedade com a natureza que irão delinear os conflitos e relações de poder entre os atores sociais da região que interferem na configuração do território, necessitando que haja uma compreensão sob uma abordagem integradora. Sobre isso, observa Haesbaert:

Encontramos aqui um outro debate muito relevante: aquele que envolve a leitura de território como um espaço que não pode ser considerado nem estritamente natural, nem unicamente político, econômico ou cultural. Território só poderia ser concebido através de uma perspectiva integradora entre as diferentes dimensões sociais (e da sociedade com a própria natureza) (HAESBAERT, 2004, p.74).

O território transita entre o material e imaterial. Além das ações humanas que são materializadas, há uma subjetividade muito grande no campo das ideias humanas e muitas vezes as representações acabam por ter mais valor do que as materialidades (HAESBAERT, 2004). Material e imaterial são inseparáveis dentro da concepção do território, estão em uma relação vital dialética, pois o território não existe sem a disputa das ideias, da mesma forma o contrário. A materialidade se refere aos produtos, aos resultados, enquanto que a imaterialidade se refere às ideias, os símbolos. O território material é a materialização das ações, dos desejos, daquilo que estava no plano das ideias. Já o território imaterial é construído a partir de interpretações da realidade, construído a partir de paradigmas que são ideológicos (RAFFESTIN, 1993). No debate do território sob uma perspectiva idealista, “ $a$ territorialidade é o conceito que se utiliza para enfatizar as questões de ordem simbólicocultural" (HAESBAERT, 2004, p.73 e p.74).

As definições de território tradicionalmente mais utilizadas para o conceito enfatizam a sua dimensão política e a sua ligação com as relações de poder (HAESBAERT, 2004). Raffestin (1993) se utilizou deste enfoque considerando a dimensão política e o papel dos Estados, mas também a sua intersecção com as dimensões econômicas e culturais da sociedade, sem se esquecer da natureza econômica e simbólica do poder. O autor trata o poder com uma visão ampliada, que apreende a concepção simbólica, a esfera de produção 
de significados, a chamada "semiosfera", afinal a materialidade não é neutra, e sim imersa em nosso sistema de significação (RAFFESTIN, 1988 apud HAESBAERT, 2004).

Não é possível separar o poder político e o poder simbólico, o poder não pode ser restrito a uma leitura materialista, como se fosse possível localizá-lo (HAESBAERT, 2004). território é uma mediação espacial do poder, resultando da diferenciada interação que ocorre entre as diferentes dimensões do poder, desde seu caráter mais político até o mais simbólico, passando pelas relações do poder econômico, indissociável da esfera jurídicopolítica (HAESBAERT, 2004).

Território tem a ver com poder, poder concreto de dominação e poder simbólico, de apropriação. A partir desse sistema é que a territorialidade acontece e ganha complexidade. A territorialidade é formada pelas relações sociais que se estabelecem no interior dos territórios. Raffestin fala em territorialidade humana, que pode ser definida como "o conjunto das relações mantidas pelo homem; como ele pertence a uma sociedade, com exterioridade e alteridade através de mediadores ou instrumentos" (RAFFESTIN, 1993, p.267). Ele acrescenta que "a territorialidade humana não é apenas constituída por relações com os territórios, mas também através de relações concretas com áreas abstratas, tais como línguas, religiões, tecnologias" (RAFFESTIN, 1993, p.267).

Para Lefebvre (1986 apud HAERSBAERT, 2004) cada grupo, classe ou instituição social pode se territorializar na relação que estabelecem com seus espaços através de um processo mais funcional (econômico-político) ou mais simbólico (político-cultural), onde dominação e apropriação são diferentes. Dominar áreas no passado era fundamental, atualmente dominar fluxos, redes e conexões é o mais importante. "Territorializar-se, desta forma, significa criar mediações espaciais que nos proporcionem efetivo "poder" sobre nossa reprodução enquanto grupos sociais [...]" (HAESBAERT, 2004, p.97).

"Sendo toda relação uma relação de poder, isso significa que o poder está ligado muito intimamente à manipulação dos fluxos que atravessam e desligam a relação, a saber a energia e a informação" (RAFFESTIN, 1993, p.53). O poder, do ponto de vista dos meios que mobiliza, é uma combinação entre energia e informação, que se apresentam em concentrações diferentes nas mais diversas relações (RAFFESTIN, 1993). Raffestin observa que para autores como Focault e Deleuze, há uma ligação declarada entre saber e poder. 
Para Raffestin (1993), na população está a origem de todo o poder, o território é o lugar de todas as relações; o espaço político por excelência, e os recursos são os horizontes possíveis de ação. População, território e recursos são os trunfos do poder, que raramente são mobilizados de forma única, tratando-se quase sempre de um trunfo complexo.

Quer se trate de redes, nós, ou tessituras, o território resulta do jogo entre os diversos atores em causa (RAFFESTIN, 1993). O território é formado por relações de poder multidimensionais, existem desigualdades, disputas e sobreposições de territórios, desde que se entenda a leitura de territórios em rede. Raffestin (1993) discutiu um sistema territorial, composto de tessituras, de nós e de redes organizadas hierarquicamente, permitindo o controle sobre aquilo que pode ser distribuído, alocado e/ou possuído, delimitando, assim, campos de ações (de poder) nas práticas espaciais que constituem o território. As malhas são heterogêneas, interligadas, possuem elementos que as complementam: pontos, nós, aglomerações de indivíduos ou grupos. Os nós são interdependentes, podem se relacionar e comunicar-se. Para Raffestin (1993:204) "a rede faz e desfaz as prisões do espaço, tornado território: tanto libera como aprisiona. É o porquê de ela ser o 'instrumento' por excelência do poder".

Raffestin, (1993) separa território e espaço geográfico, para ele o espaço, assim como o tempo, seriam como trunfos, e o território seria o campo de ação dos trunfos. O território tem uma abordagem relacional, sejam essas relações histórico-sociais ou entre os processos sociais e o espaço material. Devido a esta característica, "o território é também movimento, fluidez, interconexão - em síntese e em um sentido mais amplo, temporalidade" (HAESAERT, 2004:82).

No território da APA Bororé-Colônia há diferentes territorialidades e atores sociais. Há os hegemonizados (HAESBAERT, 2004), que utilizam o território como abrigo principalmente, mas para quem o território muitas vezes acaba virando uma combinação entre significado e funcionalidade, que pode ser exemplificado em seus grupos bem expressivos que são os agricultores e os pescadores. Mas há também há os hegemônicos (HAESBAERT, 2004), que usam do território como recurso, praticamente sem territorialidade, para quem o território tem valor de troca, é fonte de lucro, de produção, a exemplo do setor imobiliário, das empresas, do governo. Diferentemente dos produtores 
rurais e dos pescadores, para os hegemônicos o território não tem significado como lar, como abrigo.

No extremo sul do município de São Paulo, além das concepções dominantes características do modelo capitalista de produção, pautado na acumulação do capital e na apropriação da mão de obra, existem grupos que estão na contramão desse sistema, buscando uma agricultura orgânica, a pesca artesanal, uma economia de base mais solidária. Esses grupos hegemonizados compartilham de valores que em boa parte se conectam com os objetivos da APA Bororé-Colônia e eles têm grandes dificuldades em acessar o poder que interfere de fato no território. A territorialidade da população hegemonizada do extremo sul de São Paulo, seus símbolos, suas ideias, suas representações, muitas ligadas à ruralidade do território, estão sendo bombardeadas por referenciais urbanos caóticos. A pressão de grandes empreiteiras, de grupos imobiliários e de outros ligados ao capital é constante sobre o território da APABC. Há um embate constante de ideias devido às diferentes concepções e aos diferentes interesses de apropriação do território. Esses interesses e pontos de vistas divergentes vão gerar o conflito. Mas é importante observar que um conjunto de conflitos impede um tipo de desenvolvimento, não impende o desenvolvimento (FERNANDES, 2005). A conflitualidade é uma constante e um determinado conjunto de conflitos mantém certas políticas em desenvolvimento.

O conselho gestor da APA Bororé-Colônia é o espaço de governança legitimado para que a comunidade local participe da gestão da unidade de conservação e tenha voz, os conflitos fazem parte da natureza daquele fórum. O colegiado se recobre de relevância para a discussão de questões que dizem respeito à vida dos moradores da APABC, pois é fundamental como espaço de nexo entre sociedade civil e Estado, além de espaço para exposição dos interesses e atuações do poder público no território. Nessa relação de poderes os hegemonizados estão começando a se posicionar e ter representatividade, ainda que de forma incipiente. Como foi apontado no capítulo 1.7. que apresenta o conselho gestor da APA Bororé-Colônia, no colegiado existem cadeiras que contemplam a participação de associações de bairros, de agricultores e pescadores. Porém, ainda persistem grandes desafios; como a articulação social em entidades realmente representativas, a evolução para um real poder de deliberação do conselho, a promoção de alternativas que 
facilitem e permitam a participação do cidadão comum, entre outros, que serão mais detalhados ao longo do capítulo 3 que trata da governança do conselho gestor da APABC.

É importante compreender as territorialidades existentes entre a população da APA Bororé-Colônia para poder envolvê-la no processo de gestão, desenvolvimento e implantação de políticas públicas. Quando há pertencimento há amadurecimento das responsabilidades e dos direitos do cidadão, estimulando a participação política. Para a definição de políticas adequadas e coerentes para o desenvolvimento do local é necessário que haja exercício consciente e ativo dos diversos atores sociais nos processos participativos.

A reflexão teórica desenvolvida neste capítulo contribuiu para construir uma abordagem que permite enxergar no território da APA Bororé-Colônia diversos atores sociais, com interesses divergentes, relações de poderes desiguais, representações distintas, valores díspares, rebatendo em diferentes territorialidades na área de estudo. Essa lente exerceu grande influência na operacionalização dos procedimentos a partir deste referencial teórico, principalmente na análise da "boa" governança (GRAHAM; AMOS; PLUMPTRE, 2003) do conselho gestor da APA Bororé-Colônia, pois, em muitos momentos, permitiu dialogar com a perspectiva dos hegemonizados e dos hegemônicos. Partindo desse entendimento da complexidade do território, o próximo capítulo aborda os instrumentos legais que institucionalizam as unidades de conservação e sua interface com a participação social na gestão ambiental pública.

\subsection{Unidades de Conservação e participação social na gestão ambiental pública}

No Brasil, desde a colonização, ganhando força nos últimos cinquenta anos, a criação de áreas protegidas ou regimes especiais de proteção para os recursos naturais sempre esteve presente (URBAN, 2011; MEDEIROS; IRVING; GARAY, 2006). A International Union for Conservation of Nature (IUCN) é uma das entidades mais atuantes no mundo no que diz respeito à conservação da natureza, ela faz o uso do termo "áreas protegidas" para designar espaços naturais especialmente protegidos, definindo-os como:

um espaço geográfico claramente definido, reconhecido, dedicado e gerido, por meios legais ou outros instrumentos eficazes, para garantir a 
conservação em longo prazo da natureza e dos serviços ambientais e valores culturais associados ${ }^{57}$ (tradução livre da autora) (DUDLEY, 2008, p.8)

No Brasil, as áreas protegidas foram tradicionalmente estabelecidas em categorias de acordo com seus objetivos e finalidades e não eram pensadas de forma integrada. Como resultado, na década de 1990 havia nove categorias de manejo de áreas protegidas no país, geridas de modo desarticulado, ineficiente e precário (MEDEIROS; IRVING; GARAY, 2006). O Sistema Nacional de Unidades de Conservação, instituído por meio da Lei Federal no 9.985/2000 (BRASIL, 2000), regulamentada pelo Decreto 4.340/2002 (BRASIL, 2002) foi uma estratégia para estabelecer um sistema mais integrado para a criação e gerenciamento das áreas protegidas (MEDEIROS; IRVING; GARAY, 2006).

Em 2011 mais de 1,5 milhões de quilômetros quadrados, ou seja, em torno de 16,6\% do território continental e 1,5\% do território marinho brasileiros, estavam protegidos por 1.867 (mil oitocentos e sessenta e sete) unidades de conservação; sendo 310 (trezentas e dez) unidades federais, 503 (quinhentas e três) unidades estaduais, 81 (oitenta e uma) unidades municipais e 973 (novecentas e setenta e três) Reservas Particulares de Patrimônio Natural (BRASIL, 2011). No mundo, cerca de 12,8\% do território continental está protegido legalmente, considerando os números absolutos os Estados Unidos (2.607.132 km²) estão em primeiro lugar em área continental conservada, seguido da Rússia $\left(1.543 .466 \mathrm{~km}^{2}\right)$, da China $\left(1.452 .693 \mathrm{~km}^{2}\right.$ ) e do Brasil $\left(1.411 .834 \mathrm{~km}^{2}\right.$ ) (BRASIL, 2011). As APA, no Brasil, abrangem $426.273 \mathrm{~km}^{2}$

O Sistema Nacional de Unidades de Conservação define unidade de conservação (UC) como:

[...] (o) espaço territorial e seus recursos ambientais, incluindo as águas jurisdicionais, com características naturais relevantes, legalmente instituídos pelo poder público, com objetivos de conservação e limites definidos, sob regime especial de administração, ao qual se aplicam garantias adequadas de proteção (BRASIL, 2000).

O Sistema Nacional de Unidades de Conservação cria tipologias e categorias de manejo de áreas protegidas e estabelece critérios e normas para a criação, implantação e gestão das unidades de conservação. Com o SNUC foram criados dois grandes grupos de UCs, as de Proteção Integral e as de Uso Sustentável. As primeiras contabilizam cinco

\footnotetext{
57 A clearly defined geographical space, recognised, dedicated and managed, through legal or other effective means, to achieve the long-term conservation of nature with associated ecosystem services and cultural values.
} 
categorias: Estação Ecológica, Reserva Biológica, Parque Nacional, Monumento Natural e Refúgio de Vida Silvestre. Seu objetivo primordial é a preservação da natureza, sendo permitido apenas o uso indireto ${ }^{58}$ de seus recursos naturais. Já as segundas contabilizam oito categorias: Área de Proteção Ambiental, Área de Relevante Interesse Ecológico, Floresta Nacional, Reserva Extrativista, Reserva de Fauna, Reserva de Desenvolvimento Sustentável e Reserva Particular do Patrimônio Natural. O objetivo básico destas categorias de UCs é compatibilizar o uso sustentável com a conservação da natureza e nelas se permite o uso direto $^{59}$ dos recursos naturais.

A participação social na gestão ambiental foi institucionalizada na Constituição de 1988 com seus instrumentos e ferramentas legais, dentre eles os conselhos gestores. É importante entender que havia um cenário cujo pano de fundo era ampliar a participação social e evitar a dominação governamental, e isso não se restringia a questão ambiental, muito pelo contrário, os conselhos gestores, por exemplo, estão associados ao movimento da Saúde Pública e se multiplicaram para diversas áreas (ABERS; KECK, 2008). No final da década de 1990 estimou-se que existiam mais de trinta e nove mil conselhos relacionados às políticas públicas (IPEA, 2005).

É importante qualificar o entendimento sobre participação para não utilizar o conceito de forma superficial. A participação não deve ser considerada a solução para todos os problemas, embora tenha sido apropriada sob diversos interesses na elaboração, gestão e avaliação de políticas públicas.

O ser humano é por natureza um ser participativo, participar é um direito e demanda desenvolvimento da consciência crítica e aquisição de poder (BORDENAVE, 1985). A participação é um processo, é infindável, construída diariamente e está sempre inacabada (DEMO, 1988). Se aprende a participar, e se aperfeiçoa a participação, participando e refletindo, e o resultado desse processo ressoa na práxis (BORDENAVE, 1985).

Para Bordenave (1985) a palavra participação pode ser utilizada sob três significados diferentes: fazer parte, tomar parte e ser parte. Fazer parte significa participar de forma não ativa. Tomar parte significa engajamento, porém ainda sem a existência de uma participação

\footnotetext{
${ }^{58}$ O SNUC define uso indireto como "aquele que não envolve consumo, coleta, dano ou destruição dos recursos naturais" ( ${ }^{58}$ Lei Federal o 9.985/2000. Artigo 2ㅇ. Parágrafo IX).

${ }^{59}$ O SNUC define uso direto como "aquele que envolve coleta e uso, comercial ou não, dos recursos naturais" (59 Lei Federal no 9.985/2000. Artigo 2ㅇ. Parágrafo X).
} 
qualificada. Ser parte implica em lealdade e responsabilidade, em uma participação ativa e mais qualificada (BORDENAVE, 1985). Para Bordenave (1985) a luta para que os dirigentes cumpram com suas obrigações significa participação política e social.

Arnstein (2002) fala em participação cidadã, que consiste em oportunizar meios para que os excluídos dos processos políticos e econômicos possam empenhar reformas sociais que lhes permitam desfrutas dos benefícios da vida em sociedade. Participação, no processo de democratização da sociedade brasileira, significa também luta por melhores condições de vida e por benefícios advindos da civilização (GOHN, 2003).

A gestão onde se participa é diferente da gestão participativa. Tem de ficar claro que construir coletivamente a decisão a ser tomada é diferente de participar de uma reunião onde algumas decisões são tomadas (LOUREIRO; AZAZIEL; FRANCA, 2003). O órgão gestor da unidade de conservação tem de proporcionar condições para que os diferentes atores sociais envolvidos de alguma forma com a área protegida tenham oportunidade de apresentar os argumentos que fundamentam sua posição em uma situação na qual os recursos naturais estejam em disputa (QUINTAS, 2005).

O Brasil enfrenta grandes desafios para efetivar a participação da população, nossos cidadãos não se sentem parte dos processos que envolvem as políticas públicas, atribuem as responsabilidades ao Estado, inclusive a concepção de acompanhamento e cobrança de suas atuações (MACIEL, 2003). A mudança nesse cenário pode vir da educação, pois a educação é um processo formativo de ordem política, que pode ser fomentadora da cidadania e da participação (DEMO, 1988).

O SNUC também traz a questão da participação, como pode ser observado nos seguintes parágrafos do Artigo 5 que definem que suas diretrizes ${ }^{60}$ :

II - assegurem os mecanismos e procedimentos necessários ao envolvimento da sociedade no estabelecimento e na revisão da política nacional de unidades de conservação;

III - assegurem a participação efetiva das populações locais na criação, implantação e gestão das unidades de conservação;

IV - busquem o apoio e a cooperação de organizações não governamentais, de organizações privadas e pessoas físicas para o desenvolvimento de estudos, pesquisas científicas, práticas de educação ambiental, atividades de lazer e de turismo ecológico, monitoramento, manutenção e outras atividades de gestão das unidades de conservação;

\footnotetext{
${ }^{60}$ Lei Federal no 9.985/2000. Artigo 5‥ Parágrafos II, III, IV e V.
} 
$\mathrm{V}$ - incentivem as populações locais e as organizações privadas a estabelecerem e administrarem unidades de conservação dentro do sistema nacional;

Segundo o SNUC, a criação de uma unidade de conservação é realizada por ato do poder público ${ }^{61}$, mas deve ser precedida de estudos técnicos e consultas públicas que permitam identificar a localização, a dimensão e os limites mais adequados para a unidade ${ }^{62}$. Neste processo de consulta, cabe ao poder público informar a população local e demais partes interessadas o que for necessário para que as pessoas tenham condições de participar do processo ${ }^{63}$ (BRASIL, 2000; IBASE, 2006). Deste modo, entende-se como ideal que a sociedade seja consultada e faça parte do processo de criação de uma unidade de conservação, cabendo aos técnicos do poder público envolvidos realizar os procedimentos necessários para garantir a participação da sociedade.

Entretanto, conforme bem observam (IRVING et al., 2006), no Decreto Federal n-4.340/2002 que regulamenta o SNUC, consta que cabe ao órgão gestor elaborar os estudos técnicos preliminares anteriores a criação da unidade de conservação e realizar, quando for o caso, consultas públicas, conforme pode ser observado no texto na íntegra64:

Art. 4ำ Compete ao órgão executor proponente de nova unidade de conservação elaborar os estudos técnicos preliminares e realizar, quando for o caso, a consulta pública e os demais procedimentos administrativos necessários à criação da unidade.

Art. 5o A consulta pública para a criação de unidade de conservação tem a finalidade de subsidiar a definição da localização, da dimensão e dos limites mais adequados para a unidade.

§ 1ㅇ A consulta consiste em reuniões públicas ou, a critério do órgão ambiental competente, outras formas de oitiva da população local e de outras partes interessadas.

$\S 2^{\circ}$ № processo de consulta pública, o órgão executor competente deve indicar, de modo claro e em linguagem acessível, as implicações para a população residente no interior e no entorno da unidade proposta.

Não há critérios para garantir a eficiência e representatividade das consultas públicas. Existe um entendimento por parte dos órgãos gestores, sustentado pelo SNUC, de que a participação é bem vista pela sociedade, mas há de se atentar para a possibilidade desse processo encobrir a realidade e ser aparentemente participativo apenas para se cumprir o protocolo.

\footnotetext{
61 Lei Federal no 9.985/2000. Artigo 22ㅇ.

62 Lei Federal no 9.985/2000. Artigo 22‥ Parágrafo 2ㅇ.

63 Lei Federal no 9.985/2000. Artigo 22․ Parágrafo 4ㅇ.

64 Decreto Federal no 4.340/2002. Artigo 4 e Artigo 5ㅇ․
} 
Após a criação de uma unidade de conservação, o SNUC prevê dois mecanismos de participação da sociedade nos processos de tomada de decisão: o Plano de Manejo e o conselho gestor. Segundo o SNUC entende-se por Plano de Manejo ${ }^{65}$ :

[...] (o) documento técnico mediante o qual, com fundamento nos objetivos gerais de uma Unidade de Conservação, se estabelece o seu zoneamento e as normas que devem presidir o uso da área e o manejo dos recursos naturais, inclusive a implantação das estruturas físicas necessárias à gestão da unidade (BRASIL, 2000).

Todas as unidades de conservação devem dispor de um Plano de Manejo. Segundo o SNUC66: "o Plano de Manejo deve abranger a área da Unidade de Conservação, sua zona de amortecimento e os corredores ecológicos ${ }^{67}$, incluindo medidas com o fim de promover sua integração à vida econômica e social das comunidades vizinhas".

Ele deve ser elaborado em até cinco anos a partir da data de criação da unidade de conservação ${ }^{68}$. Por ser um documento complexo, que envolve a participação de técnicos de diversas áreas e por ter um custo muitas vezes elevado, as unidades de conservação acabam demorando a elaborar seus Planos de Manejo. O SNUC prevê que ${ }^{69}$ :

Até que seja elaborado o Plano de Manejo, todas as atividades e obras desenvolvidas nas Unidades de Conservação de proteção integral devem se limitar àquelas destinadas a garantir a integridade dos recursos que a unidade objetiva proteger, assegurando-se às populações tradicionais porventura residentes na área as condições e os meios necessários para a satisfação de suas necessidades materiais, sociais e culturais (BRASIL, 2000).

No "Roteiro Metodológico de Planejamento. Parques Nacionais, Reservas Biológicas e Estações Ecológicas", o Ministério do Meio Ambiente - MMA, por meio de seu órgão federal de meio ambiente na época, o Instituto Brasileiro de Meio Ambiente e Recursos Naturais Renováveis - IBAMA, orienta como deve ser a elaboração de um Plano de Manejo para as referidas unidades de conservação (GALANTE et al., 2002). O planejamento participativo é indicado como fundamental para garantir o sucesso do Plano de Manejo e, mais do que isso, da unidade de conservação (GALANTE et al., 2002). A metodologia proposta visa envolver a

\footnotetext{
65 Lei Federal no 9.985/2000. Artigo 20. Inciso XVII.

${ }^{66}$ Lei Federal no 9.985/2000. Artigo 27ㅇ.

${ }^{67} \mathrm{O}$ Corredor Ecológico é um instrumento de gestão e ordenamento territorial com o objetivo de garantir a manutenção dos processos ecológicos nas áreas de conexão entre Unidades de Conservação, permitindo a dispersão de espécies, a recolonização de áreas degradadas, o fluxo gênico e a viabilidade de populações que demandam mais do que o território de uma unidades de conservação para sobreviver (Lei Federal no9.985/2000. Artigo 2ㅇ).

68 Lei Federal no 9.985/2000. Artigo 27ㅇ. Parágrafo 3ㅇ.

${ }^{69}$ Lei Federal no 9.985/2000. Artigo 28‥ Parágrafo único.
} 
sociedade tanto na etapa de planejamento, que consiste nos estudos que vão dar subsídios a elaboração do Plano de Manejo, quanto na etapa de implementação do Plano de Manejo, que consistem na gestão da UC. As oficinas de planejamento no enfoque participativo são indicadas como "etapas básicas para a elaboração técnica do Plano de Manejo da UC" (GALANTE et al., 2002, p. 27).

A APA Bororé-Colônia ainda não possui Plano de Manejo. Dada à diversidade de atores presentes no território da unidade de conservação e considerando também a complexidade de objetivos de gestão que a categoria contempla, a ausência de um Plano de Manejo é um empecilho para sua gestão, tornando-a mais difícil. Não que o Plano de Manejo seja a panaceia para todos os problemas, mas além de estabelecer um zoneamento e ordenar os usos no território, ele tem poder de documento legal, o que confere maior legitimidade na busca dos objetivos de gestão da APABC.

Por fim, e não menos importante; ao contrário, uma vez que é o foco do presente estudo, como foi mencionado além das consultas públicas e dos Planos de Manejo, temos também os conselhos gestores como espaços de participação cidadã na gestão ambiental pública. Os conselhos gestores das unidades de conservação são os espaços coletivos de participação, discussão, negociação, tomada de decisão e compartilhamento de experiências previstos no SNUC (IRVING, et al., 2006). Segundo o SNUC ${ }^{70}$ :

$\S$ 5 A Área de Proteção Ambiental disporá de um conselho presidido pelo órgão responsável por sua administração e constituído por representantes dos órgãos públicos, de organizações da sociedade civil e da população residente, conforme se dispuser no regulamento desta Lei.

No estado de São Paulo, as APA cuja gestão é feita pelo Governo Estadual de São Paulo possuem conselhos consultivos, conforme estabelecido no Decreto Estadual n-48.149/2003 (SÃO PAULO, 2003). Já a APA Bororé-Colônia, objeto deste estudo, cuja gestão cabe a Prefeitura Municipal de São Paulo, possui um conselho gestor deliberativo ${ }^{71}$, característica muito importante e inovadora na busca por uma participação efetiva na gestão ambiental pública.

\footnotetext{
${ }^{70}$ Lei Federal no 9.985/2000. Artigo 29ㅇ․

${ }^{71}$ Lei Municipal no 14.162/2006.
} 
A definição de APA no SNUC, citada a seguir, traz objetivos que estão amplamente relacionados com o uso que é feito pelas populações humanas de seu território, por isso tem por essência a participação social em sua gestão para empreender sucesso ${ }^{72}$ :

A Área de Proteção Ambiental é uma área em geral extensa, com um certo
grau de ocupação humana, dotada de atributos abióticos, bióticos,
estéticos ou culturais especialmente importantes para a qualidade de vida e
o bem-estar das populações humanas, e tem como objetivos básicos
proteger a diversidade biológica, disciplinar o processo de ocupação e
assegurar a sustentabilidade do uso dos recursos naturais (BRASIL, 2000).

Dada suas características, as terras da APA podem ser públicas ou privadas $^{73}$, reforçando a necessidade das pessoas que habitam aquele território serem envolvidas em sua gestão. A APA só existe para aqueles que a reconhecem, seus limites não estão delimitados fisicamente no território de modo que seja possível identificá-los ao olhar para a paisagem. Não é tão fácil perceber os limites da APA Bororé-Colônia, diferentemente de outras áreas, cujos limites são mais fáceis de reconhecer em campo. Se as pessoas não conhecem sua existência, não compartilham de seus objetivos e não a enxergam em seus cotidianos, para esses cidadãos a APA não existe.

A reflexão teórica proposta neste capítulo contribuiu para construir uma abordagem que permite enxergar o direcionamento legislativo, bem como as possibilidades de participação social na gestão ambiental das unidades de conservação - em especial nas Áreas de Proteção Ambiental -, além de qualificar o entendimento sobre a participação. $\mathrm{Na}$ operacionalização do referencial teórico de "boa" governança (GRAHAM; AMOS; PLUMPTRE, 2003) essa abordagem contribuiu para que o olhar tivesse maior profundidade e conexão com a legislação vigente e considerasse o entendimento de diferentes possibilidades de participação. Partindo desse entendimento da interface da participação social com os instrumentos legais, o próximo capítulo aprofunda a análise sobre a governança na gestão das unidades de conservação.

\subsection{Governança e "boa" governança na gestão de unidades de conservação}

O território, formado a partir das transformações decorrentes das relações sociais estabelecidas em um espaço físico e condicionadas pelas relações de poder (RAFESTTIN,

72 Lei Municipal no 14.162/2006. Artigo 15ㅇ․

${ }^{73}$ Lei Federal no 9.985/2000. Artigo 15‥ Parágrafo I. 
1993), é palco de divergências entre grupos com objetivos opostos e, portanto, constitui-se como espaço de oportunidades para o surgimento de ideias, projetos e políticas que o modifique. Diferentes atores e instituições, como empreendedores do trade turístico, associações de classe, líderes comunitários, gestores e conselheiros das unidades de conservação, exercem pressões para manterem suas atividades e/ou seus ideais e projetos de desenvolvimento local e de conservação ambiental, colocando em evidência a necessidade de discussões mais profundas sobre os pressupostos de participação e governança em áreas naturais.

A história da proteção da natureza no Brasil teve avanços e recuos. As áreas protegidas se multiplicaram e se expandiram pelo território nacional, fruto da evolução que ocorreu no plano institucional, legal e de políticas públicas, porém o efetivo funcionamento destas áreas é impedido por indefinições e por condicionantes históricos (MEDEIROS; IRVING; GARAY, 2006). Entres estes, podem-se citar as limitações financeiras e de recursos humanos e os problemas ligados à ausência de uma estratégia clara de integração das áreas protegidas à dimensão local e às questões globais (MEDEIROS; IRVING; GARAY, 2006).

Medeiros, Irving e Garay (2006) acreditam que, apesar de esses conflitos gerarem muitos efeitos negativos para a consolidação destas áreas protegidas, eles têm contribuído para incentivar o processo participativo na criação e gestão das unidades de conservação e para o desenvolvimento de modelos inovadores de gestão e parcerias. O caminho para fortalecer o sistema de áreas protegidas no Brasil está na compreensão da perspectiva social intimamente associada à proteção da natureza, somada ao fortalecimento dos canais de diálogo entre os diferentes atores sociais e setores nacionais e internacionais (MEDEIROS; IRVING; GARAY, 2006).

Cada área protegida merece ser pensada com suas especificidades, levando em conta as necessidades e o contexto que envolve as comunidades locais que ali residiam e ainda residem. Na APA Bororé-Colônia não existe populações tradicionais, dentro da visão de que as comunidades tradicionais dependem economicamente do uso de recursos naturais renováveis, com baixos padrões de consumo, baixa densidade populacional e limitado desenvolvimento tecnológico (DIEGUES, 2001). O que existe na APABC é uma população periurbana, de baixo poder econômico, onde algumas pessoas ainda extraem seu sustento de atividades com base no uso de recursos naturais renováveis, mas muitas outras vendem 
sua mão de obra para obter seu sustento. São cidadãos carentes de serviços sociais e o fato de não haver uma comunidade tradicional na $A P A B C$ não torna as pessoas que habitam essa área menos importantes, muito menos quando se trata da participação social na gestão das UCs.

A sociedade é a principal ameaça em potencial e também a principal parceira em potencial para garantir a efetiva proteção da biodiversidade, há um caminho de mão dupla, onde não deve-se priorizar apenas a conservação, mas deve-se dar grande atenção ao bem estar e a qualidade de vida da população que se relaciona com a unidade de conservação. Neste sentido, é preciso envolver a sociedade na gestão das áreas protegidas para que possam contribuir efetivamente, trazendo para a discussão as suas necessidades e aspirações para com aquele espaço; compreendendo também as fragilidades e demandas daquela área e seu papel como cidadãos na sua gestão; de modo que possam usufruir de benefícios advindos da existência da unidade de conservação.

As redes de relações entre os diversos atores sociais são estabelecidas desde o momento do projeto de criação de uma área protegida (IRVING, et al., 2006). Para uma gestão viável, eficiente e efetiva destas áreas em longo prazo faz-se necessário haver um entendimento entre os administradores das UCs, os grupos humanos envolvidos na região da área protegida e também clareza nos benefícios socioeconômicos que estas áreas podem gerar. A natureza protegida pode ser entendida pela comunidade local como fonte de cidadania, como patrimônio coletivo, e esse movimento tende a resultar na redução da pressão sobre a área protegida (IRVING, et al., 2006), além de poder trazer benefícios aos cidadãos.

O conceito de governança nos ajuda a compreender a complexidade da relação entre as áreas protegidas e a sociedade na gestão ambiental pública. Governança é um termo que se tornou popular a partir da década de 1990 e que possui diversas interpretações sobre seu significado. Frequentemente, governança é confundida com governo, mas a necessidade de diferenciar estes conceitos manifesta-se quando o governo torna-se uma organização que está distante dos cidadãos (GRAHAM; AMOS; PLUMPTRE, 2003).

Graham, Amos e Plumptre (2003) trazem a reflexão de que em sociedades antigas, a exemplo da grega, o governo era apenas um processo dentro da organização social, e que 
atualmente ele é um dos atores sociais. A representação a partir do governo se fez necessária em grandes sociedades, mas ela é imperfeita; o ideal seria que ao se descortinar essa representação se enxergasse a sociedade, mas quando quem dirige as atividades do governo não é a própria sociedade o governo acaba por se torna algo a parte (GRAHAM; AMOS; PLUMPTRE, 2003).

Em uma realidade na qual os governos não refletem a participação social, faz-se necessário aprofundar a discussão sobre a interação da sociedade com a gestão pública. De acordo com o Programa das Nações Unidas para o Desenvolvimento (PNUD), governança:

[...] engloba a interação entre as estruturas, os processos, as tradições e sistemas de conhecimento, que determinam a forma pela qual se exerce o poder, a responsabilidade e as tomadas de decisão, e na qual os cidadãos e outros interessados diretos expressam sua opinião. Esse conceito se aplica as Áreas Protegidas em todos os níveis: local, nacional, regional e mundial. ${ }^{74}$

Governança é definida pelos autores GRAHAM, AMOS e PLUMPTRE (2003, p. ii) ${ }^{75}$ como " as interações entre as estruturas, processos e tradições que determinam como $o$ poder e as responsabilidades são exercidos, como as decisões são tomadas, e como os cidadãos e os stakeholders tem sua voz"176

Este é o entendimento que orienta o olhar neste estudo. Fundamentalmente, trata de como interagem o governo e diversas organizações sociais, como se relacionam com os cidadãos e como são tomadas as decisões em um mundo cada vez mais complexo (GRAHAM; AMOS; PLUMPTRE, 2003)). Ainda que existam diversos conceitos de governança, em geral, muitos autores concordam que governança diz respeito à tomada de decisões sobre os caminhos a seguir (COMISSÃO SOBRE GOVERNANÇA GLOBAL, 1996; GRAHAM; AMOS; PLUMPTRE, 2003; IRVING, et.al., 2006; SANTOS JUNIOR; AZEVEDO; RIBEIRO, 2004).

Um conceito breve, segundo Graham, Amos e Plumptre (2003) seria o de que governança é a arte de dirigir sociedades e organizações, no entanto os autores se perguntam se esse conceito está impregnado de conotações de direção de cima para baixo ou de controle dos que são muito fortes, e se direção seria a palavra mais apropriada. De

\footnotetext{
${ }^{74}$ Livre tradução do Acuerdo de Durban. Durban (IUCN, 2003) apud Irving, et al., 2006.

75 Os autores representaram a instituição Parks Canada que liderou a implementação de um fluxo de governança no 50 Congresso Mundial de Parques, realizado na África do Sul em 2003.

76 Livre tradução. "We define governance as the interactions among structures, processes and traditions that determine how power and responsibilities are exercised, how decisions are taken, and how citizens or other stakeholders have their say".
} 
modo complementar, IRVING et.al. (2006) apontam que na área de administração há uma extensa produção acadêmica sobre o que é conhecido por governança corporativa, que teve como proposta inicial substituir a gestão vertical e hierarquizada por uma organização em rede, mais global, que permitisse melhor gestão das corporações e maior interação com as demandas geradas pela inclusão de parceiros externos. O conceito de governança em áreas protegidas, entretanto, não é o mesmo que o conceito de governança na administração, pois não existe a mesma hierarquia verticalizada, pelo menos não deveria existir.

Governança tem a ver com a interação entre estruturas, tradições e processos que determinam como se dará o exercício do poder e da responsabilidade, como se dará o processo de tomadas de decisão e como os cidadãos e as lideranças sociais serão ouvidos (GRAHAM; AMOS; PLUMPTRE, 2003). Em essência, governança trata de poder, relações e prestações de conta. Quem influencia? Quem decide? Como os tomadores de decisão são responsabilizados? (GRAHAM; AMOS; PLUMPTRE, 2003).

Como pode ser observado no ANEXO B, desde o IV Congresso Mundial de Parques, realizado em 1992 em Caracas, que a participação da sociedade na gestão das áreas protegidas tem ganhado mais espaço, estando presente, inclusive, nas recomendações emitidas pelos participantes. No V Congresso Mundial de Parques, realizado em 2003 em Durban, foi publicado o acordo de Durban que reconhece a relevância dos processos participativos e recomenda que sejam adotados mecanismos que permitam a representação e a participação de todos os atores locais envolvidos com a unidade de conservação.

Se conceituar governança já é desafiador, conceituar o que é "boa" governança na gestão de unidades de conservação é ainda mais. Neste sentido Graham, Amos e Plumptre (2003) partiram do princípio de que a variedade de objetivos das áreas protegidas pode ser agrupada em quatro itens: a conservação da natureza, a pesquisa científica, as oportunidades de uso público e as necessidades dos habitantes locais e comunidades tradicionais. Tendo como meta atingir estes objetivos, entende-se que os responsáveis pelas UCs podem exercer diferentes tipos de poder: poder de planejamento, poder regulamentador, poder de gasto, poder gerador de receitas e o poder de celebrar acordos. "Boa" governança trata de exercer esses poderes de modo responsável com a intenção de atender aos objetivos da UC. 
Com base nesse entendimento, e tendo como ponto de partida a lista com treze características de boa governança publicada pelo Programa das Nações Unidas para o Desenvolvimento (PNUD), os autores criaram cinco grandes temas e os preencheram com critérios de boa governança, conforme pode ser observado no quadro no 6, a na próxima página. 
Quadro 6: Boa governança - Legitimidade e voz e Direcionamento com base em Graham, Amos e Plumptre (2003). Continua.

\begin{tabular}{|c|c|}
\hline PRINCíPIO & CRITÉRIOS \\
\hline \multirow{6}{*}{ 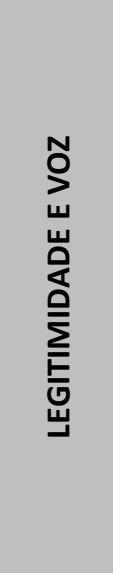 } & $\begin{array}{l}\text { Existência de contexto de suporte democrático e de direitos humanos, através de: instituições democráticas baseadas na eleição livre e em um sistema multipartidário viável; respeito aos } \\
\text { direitos humanos como liberdade de expressão, de associação e de religião; inexistência de discriminação baseada em raça, cor ou religião; promoção da tolerância e da harmonia social; } \\
\text { respeito aos direitos dos povos indígenas. }\end{array}$ \\
\hline & $\begin{array}{l}\text { Grau apropriado de descentralização na tomada de decisões nas unidades de conservação, de modo que qualquer decisão seja feita a nível local, através de estruturas que: prestem contas à } \\
\text { população; trabalhem o poder e capacidade necessários ao desempenho de suas funções; trabalhem dentro de algumas condições, como parâmetros ambientais mínimos, visando objetivos } \\
\text { mais amplos, de interesse nacional e internacional. }\end{array}$ \\
\hline & Gestão participativa nas tomadas de decisão da unidade de conservação envolvendo representantes de todas as partes afetadas, especialmente as comunidades locais e os povos indígenas. \\
\hline & $\begin{array}{l}\text { Participação dos cidadãos ocorrendo em todos os níveis de tomada de decisão relacionados à unidade de conservação (legislação, planejamento de sistemas, criação e implantação de UCs, } \\
\text { planejamento da gestão, operação) com ênfase no nível local e na participação equitativa de homens e mulheres. }\end{array}$ \\
\hline & Existência de associações civis e mídia independente que monitorem e possam exercer um contrabalanço no exercício do poder decisório das lideranças políticas e dos gestores da UC. \\
\hline & Alto nível de confiança entre os vários atores envolvidos no manejo da unidade de conservação (governamentais, não governamentais, nacional, estadual e local). \\
\hline PRINCíPIO & CRITÉRIOS \\
\hline \multirow{5}{*}{ 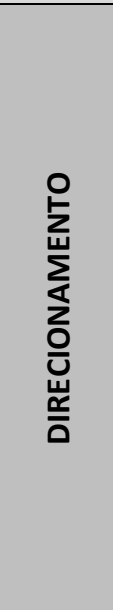 } & $\begin{array}{l}\text { Conformidade com o direcionamento internacional relativo às unidades de conservação, como as Convenções Internacionais (exemplo Convenção sobre a Proteção do Patrimônio Mundial, } \\
\text { Cultural e Natural; Convenção da Biodiversidade; Convenção de Ramsar relativa às Zonas Úmidas de Importância Internacional); os Programas Intergovernamentais (exemplo o Programa } \\
\text { Homem e Biosfera da UNESCO); os acordo regionais (exemplo Natura } 2000 \text { da União Europeia e a Convenção de Aves Migratórias da América do Norte). }\end{array}$ \\
\hline & $\begin{array}{c}\text { Existência de direcionamento legislativo (formalizado ou com regras tradicionais) que: indique propósitos e critérios claros para as unidades de conservação; estabeleça claramente a } \\
\text { competência das autoridades em relação aos meios de gestão (instrumentos de governança); forneça condições para que instituições viáveis administrem as UCs; inclua exigências para que os } \\
\text { cidadãos participem da tomada de decisão; seja elaborado na forma de proposições escritas. }\end{array}$ \\
\hline & $\begin{array}{l}\text { Existência de um sistema nacional de unidades de conservação planejado que: estabeleça objetivos quantificáveis para a gestão de diferentes categorias de UCs; defina prioridades para a } \\
\text { fase de planejamento; inclua requisitos em sua implementação para a participação dos cidadãos, em especial a população local e os povos indígenas. }\end{array}$ \\
\hline & $\begin{array}{c}\text { Existência de planos de gestão individualizados para as unidades de conservação que: reflitam a participação dos cidadãos, comunidade local e povos indígenas; tenha aprovação formal das } \\
\text { autoridades competentes; estabeleçam objetivos claros que estejam de acordo com a legislação; estabeleçam resultados mensuráveis a serem alcançados e seu cronograma; sejam revisados e } \\
\text { atualizados regularmente. }\end{array}$ \\
\hline & $\begin{array}{l}\text { Demonstração de liderança efetiva, incluindo lideranças políticas e gestores responsáveis pelo sistema e pelas unidades de conservação individualmente, que: ofereça uma visão inspiradora e } \\
\text { consistente ao desenvolvimento em longo prazo da UC ou do sistema de UCs; mobilize apoio para esta visão; reúna os recursos necessários à implementação dos diversos planos do sistema ou } \\
\text { de UCs individualmente. }\end{array}$ \\
\hline
\end{tabular}

Fonte: GRAHAM; AMOS; PLUMPTRE (2003). Traduzido pela autora. 
Quadro 6: Boa governança - Desempenho, Prestação de Contas e Equidade com base em Graham, Amos e Plumptre (2003). Conclusão.

\begin{tabular}{|c|c|}
\hline PRINĆ́PIO & CRITÉRIOS \\
\hline \multirow{8}{*}{ 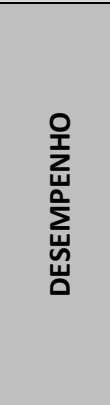 } & $\begin{array}{l}\text { CRITERIOS } \\
\text { Eficiência em atingir objetivos: conservação, ciência, oportunidades de visitação. }\end{array}$ \\
\hline & $\begin{array}{l}\text { Capacidade de se encarregar das funções requisitadas, especialmente as ligadas a sua gestão (por exemplo: conservação, ciência, oportunidades de visitação, necessidades locais), a sua } \\
\text { autoridade (por exemplo: regulação e planejamento, controle de aplicação de recursos, geração de rendas, acordos), e a sua capacidade técnica. }\end{array}$ \\
\hline & Coordenação: habilidade e capacidade para coordenar esforços com os principais atores envolvidos, governamentais ou não. \\
\hline & Informações ao público sobre o desempenho: prover informação suficiente para facilitar a cooperação governamental e do público em geral. \\
\hline & Responsividade: capacidade de lidar com queixas e críticas do público. \\
\hline & $\begin{array}{c}\text { Monitoramento e Avaliação: capacidade de se comprometer com monitoramento e avaliações abrangentes e regulares, incluindo monitoramento de longo prazo de indicadores chave } \\
\text { culturais e ecológicos, e responder aos achados. }\end{array}$ \\
\hline & Gestão adaptativa: parte da estratégia exige habilidade em exercer uma política de aprendizagem e de ajuste das ações de gerenciamento a partir da experiência operacional. \\
\hline & Gerenciamento de riscos: capacidade em identificar riscos e gerenciá-los. \\
\hline PRINĆ́PIO & CRITÉRIOS \\
\hline \multirow{6}{*}{ 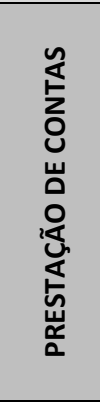 } & Clareza na articulação de responsabilidades e autoridade para agir é fundamental para responder a pergunta "quem é responsável perante a quem e para quê?". \\
\hline & $\begin{array}{l}\text { Coerência e visão: grau em que conceitos mais amplos de prestação de contas à comunidade global, às futuras gerações e à natureza são integrados com os conceitos mais tradicionais de } \\
\text { prestação de contas política. }\end{array}$ \\
\hline & $\begin{array}{l}\text { Papel dos líderes políticos: adequação das responsabilidades atribuídas aos cargos eletivos, em contraposição ao papel de autoridades não eleitas e de órgãos de administração indireta, e } \\
\text { ausência de corrupção. }\end{array}$ \\
\hline & $\begin{array}{c}\text { Instituições públicas de prestações de contas: instituições de prestação de contas eficazes, o que inclui acesso à informação, capacidade de analisar e denunciar, capacidade de instaurar } \\
\text { processos com mandatos abrangentes. }\end{array}$ \\
\hline & Sociedade civil e mídia: efetividade da sociedade civil e da mídia em mobilizar as demandas por prestação de contas. \\
\hline & $\begin{array}{l}\text { Transparência: capacidade dos cidadãos, da sociedade civil, e da mídia em acessar informações relevantes para o desempenho da gestão da unidade de conservação e empregá-las com poder } \\
\text { regulatório, no controle da aplicação de recursos e outros. }\end{array}$ \\
\hline PRINCÍPIO & $\begin{aligned} \text { CRITÉRIOS } \\
\end{aligned}$ \\
\hline \multirow{4}{*}{ 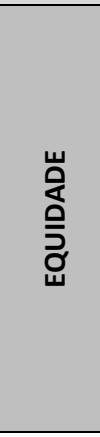 } & $\begin{array}{l}\text { Existência de um contexto de apoio judicial caracterizado pelo respeito ao Estado de direito, incluindo: Poder Judiciário independente, igualdade perante a Lei, exigência de que governos e } \\
\text { seus funcionários baseiem suas ações em atribuições legais bem definidas, direito dos cidadãos em buscar garantias legais contra o governo e demais cidadãos. }\end{array}$ \\
\hline & $\begin{array}{l}\text { Correção, imparcialidade e eficácia na aplicação das normas relativas à unidade de conservação, incluindo: transparências das normas (sua existência é conhecida e acessível); ausência de } \\
\text { corrupção entre funcionários públicos; direito de recurso para aqueles acusados de transgressões. }\end{array}$ \\
\hline & $\begin{array}{l}\text { Equidade na criação de novas unidades de conservação, incluindo: respeito aos direitos, usos e conhecimentos tradicionais das comunidades locais e povos indígenas ligados com a área; uma } \\
\text { avaliação de outras opções para a utilização da área; a participação pública no processo de criação da unidade de conservação, incluindo principalmente as comunidades locais e os povos } \\
\text { indígenas; o equilíbrio adequado entre os objetivos da UC (uso local, ciência, conservação e o uso dos visitantes). }\end{array}$ \\
\hline & $\begin{array}{l}\text { Equidade na gestão de unidades de conservação, incluindo: práticas que obtenham um equilíbrio favorável entre custos e benefícios para a comunidade local e para os povos indígenas (por } \\
\text { exemplo as práticas tradicionais, distribuição de renda, preferência para emprego e contratação); mecanismos que permitam ceder ou compartilhar as tomadas de decisão da gestão da UC } \\
\text { com as comunidades locais e povos indígenas; emprego de conhecimentos e métodos de gestão de recursos tradicionais; prática de gestão de recursos humanos equitativos para a equipe da } \\
\text { UC; processo de reconhecimento e de trato com as injustiças do passado resultantes da criação e implantação da UC. }\end{array}$ \\
\hline
\end{tabular}

Fonte: GRAHAM; AMOS; PLUMPTRE (2003). Traduzido pela autora. 
O Programa das Nações Unidas para o Desenvolvimento coloca que democracia e desenvolvimento humano são uma viagem e não um destino (GRAHAM; AMOS; PLUMPTRE, 2003). Não há consenso se seria adequado propor um conjunto universal de princípios de boa governança para esta jornada, pois as sociedades valorizam os resultados de formas diferentes, por isso a ênfase atribuída aos aspectos de governança varia em diferentes sociedades (GRAHAM; AMOS; PLUMPTRE, 2003). Existem diferentes representações do mundo natural, do espaço público, que variam em diferentes culturas (DIEGUES, 2001). Por exemplo, algumas culturas valorizam direitos individuais enquanto outras colocam mais pressão sobre os valores comunitários. Enquanto algumas culturas valorizam seu desenvolvimento cultural, outras valorizam mais seu desenvolvimento econômico.

Determinar o que é boa governança passa por uma discussão de valores, de cultura, de resultados econômicos e sociais desejados (GRAHAM; AMOS; PLUMPTRE, 2003). Isso leva a perguntas sobre o papel do governo, como se relacionam com os cidadãos, as relações entre os diversos poderes do governo, os papéis dos diferentes setores. Essa tentativa de desenvolver um entendimento de boa governança representa um ideal que nenhuma sociedade atual teve condições de atingir plenamente (GRAHAM; AMOS; PLUMPTRE, 2003).

Neste sentido, os autores trazem para reflexão que é importante compreender os princípios de "boa" governança não como compartimentos estanques, mas de modo dinâmico, eles podem se sobrepor e muitas vezes se reforçam. Porém, em alguns momentos há conflitos entre os princípios, o que exige ponderação e equilíbrio na sua aplicação (GRAHAM; AMOS; PLUMPTRE, 2003). O contexto social é um fator que sempre irá interferir na aplicação dos princípios e as complexidades são abundantes e sempre se farão presentes.

Ainda que a pauta da inclusão social se faça presente no Brasil, a participação da sociedade na gestão das áreas protegidas parece periférica ou experimental, o que indica que o processo ainda está em sua fase inicial e merece ser pensando no sentido de se delinear os contextos e rumos desejados. Essa abordagem permite vislumbrar que há muitas oportunidades para se construir uma nova realidade brasileira no que diz respeito à participação social na gestão ambiental pública.

A reflexão teórica proposta neste capítulo foi fundamental para a análise proposta neste estudo e, sem dúvida, sua aplicação prática foi influenciada pelos demais referenciais 
teóricos presentes neste estudo e pelas especificidades da APA Bororé-Colônia e de seu conselho gestor. A partir da operacionalização do referencial teórico de "boa" governança (GRAHAM; AMOS; PLUMPTRE, 2003), realizada no capítulo 3, foi possível iniciar uma reflexão sobre o papel do governo em lidar com as questões públicas e a contribuição que outros atores sociais podem ter na gestão ambiental pública. Essa abordagem permitiu pensar que outros setores da sociedade, além do poder público, podem desempenhar papéis mais fortes na abordagem dos problemas. Também reforçou a reflexão que reforça a necessidade do poder público garantir a igualdade de direitos de todos os cidadãos, garantindo que os não representados tenham seus direitos assistidos em colegiados como o conselho gestor da APA Bororé-Colônia. Para que esta análise não fique desconectada dos aspectos das políticas públicas que as influenciam, no capítulo a seguir será realizada essa reflexão a luz de alguns conceitos da ciência política.

\subsection{Aspectos das políticas públicas que influenciam na governança dos conselhos gestores de unidades de conservação}

Existem diversas definições para políticas públicas, a partir de uma revisão de literatura Souza a resumiu como "o campo do conhecimento que busca, ao mesmo tempo, colocar o governo em ação e/ou analisar essa ação (variável independente) e, quando necessário, propor mudanças no rumo ou curso dessas ações (variável dependente)." (SOUZA, 2006, p. 26). Alguns conceitos trabalhados dentro do campo da ciência política auxiliam na compreensão de enlaces das políticas públicas que permeiam a governança em conselhos gestores de unidades de conservação.

Por conseguinte, o conceito de arenas inicia nossa reflexão. A arena não diz respeito ao espaço físico ou institucional, mas sim aos padrões de interação dos atores envolvidos em uma política (LOWI, 1972). As arenas participativas permitem que as decisões sejam tomadas levando em conta o melhor argumento obtido em um processo de discussão pública (COELHO, 2004). A partir das expectativas e preferências os atores vão mobilizar o conflito, as alianças e as negociações (COELHO, 2004). Os participantes nessa arena são simultaneamente independentes e interdependentes, no sentido de que uma solução não pode ser imposta, mas se o grupo não chegar a uma solução todos perdem (SCHIMITTER apud COELHO, 2004). 
Há múltiplos interesses que incidem sobre o território da APA Bororé-Colônia e os recursos naturais possuem usos diferenciados, o que torna necessário a intervenção do poder público para o ordenamento destes usos para que todas as partes envolvidas sejam ouvidas. O conselho gestor da APABC é a arena participativa de interação onde se desenvolvem as relações entre diversos atores sociais e grupos de interesse envolvidos com a área protegida, incluindo tanto o poder público quanto a sociedade civil.

O segundo conceito que auxilia na compreensão das políticas públicas que influenciam o funcionamento dos conselhos gestores consiste nas redes de políticas públicas. As redes são comunidades densas e fechadas, nas quais "seus membros partilham de um sentido cognitivo acerca da política pública que os reúne" (MASSARDIER, 2006, p. 175). Elas se formam ao redor de problemas e/ou programas de políticas públicas, possuem padrões mais ou menos estáveis de relações sociais, contam com uma diversidade de atores que possuem seus próprios interesses pessoais e sua existência se deve a interdependência dinâmica que existe entre estes atores (KLIJN, 1998). Na medida em que as relações entre esses atores são mais estreitas e duráveis, ou seja, quando o sistema de trocas é constituído, a rede torna-se mais estável, impenetrável e coerente (MASSARDIER, 2006). Novos atores têm custos para ingressarem em uma rede que podem ser altos; custos estes que se relacionam com aprendizado de linguagem e regras, estabelecimento de padrões e relações, e oferta de benefícios para um ou mais atores da rede (MASSARDIER, 2006; KLIJN, 1998). Mesmo entre os atores de uma mesma rede pode se dizer que os custos para estarem presentes também são diferenciados.

Não há monopólio por parte de uma organização da relação com o Estado (LOWI, 1969; PETERS, 1869 apud MASSARDIER, 2006). Existe uma competição reduzida de acesso ao governo entre os atores, isso porque as autoridades que representam os órgãos e entidades estatais têm interesses próprios, e acabam por buscar apoio para implantar seus programas em grupos específicos (MASSARDIER, 2006). Existe também concorrência entre redes paralelas para a definição de uma mesma política pública (HECLO; WILDAVSKI, 1974 apud MASSARDIER, 2006) e o crescimento no número de interesses leva a criação de novas redes, de modo que "o interesse coletivo torna-se, como seu nome indica, um conjunto de interesses" (HECLO; WILDAVSKI, 1974, p. 365 apud MASSARDIER, 2006). 
Boa parcela dos estudos brasileiros sobre conselhos os enxerga como novas arenas deliberativas que estimulam a maior participação direta dos cidadãos nos processos de tomada de decisão pública, entretanto sua estrutura organizacional vai de encontro a essa visão, demonstrando que a participação nesses fóruns é indireta (ABERS; KECK, 2008). De um lado, os membros de um conselho devem representar grupos de associações civis, de movimentos sociais, do setor privado, entre outros, com respaldo social e com missões que correspondem às finalidades do conselho. Em sua outra metade estão os representantes do governo, em uma noção difícil de aceitar do ponto de vista teórico de que o Estado pode ser representado como um interesse parcial, que não deixa claro quais interesses estão sendo representados (ABERS; KECK, 2008).

Esse modelo de representação combinada de órgãos estatais e organizações da sociedade civil é fruto de uma história onde movimentos populares e burocratas reformistas foram atores importantes (ABERS; KECK, 2008). Os conselhos surgiram no Brasil originados do movimento da Saúde Pública, que pautada na descentralização e na participação procurou evitar a dominação governamental. Em um primeiro momento, essa conquista de paridade de cadeiras entre poder público e sociedade civil ${ }^{77}$ foi vista como um grande progresso e como um meio de tornar a formulação de políticas mais inclusivas e mais representativas de interesses sociais mais amplos, porém estudos empíricos trouxeram poucas evidências dessa contribuição (ABERS; KECK, 2008). Na tentativa de explicar esse fracasso, analistas têm trazido quatro explicações gerais: a maioria das vezes quem compõe o conselho não é representante das classes populares, a relação entre os representantes e os representados na sociedade civil é muito frágil, os órgãos governamentais controlam a agenda e os governos locais tendem a tratar o conselho como órgão consultivo (ABERS; KECK, 2008).

Os conselhos não exaurem a participação, mas a restringem de forma parcial, eles podem ser entendidos como redes de políticas públicas fechadas e estáveis. O Artigo 24ㅇ da lei de criação da APA Bororé-Colônia indicada as representações do seu conselho gestor, conforme relatado no quadro 1 , presente no capítulo 1.7 . No caso do conselho gestor da APABC há de se reconhecer que sua composição é bem representativa dos atores que atuam

\footnotetext{
77 Algumas páginas adiante, no capítulo 3.1 que trata da legitimidade para a "boa" governança, mais especificamente no critério que aborda a gestão participativa nas tomadas de decisão da unidade de conservação, será aprofundada a análise da paridade.
} 
no território da unidade de conservação, inclusive constam camadas da população que foram historicamente alijadas dos processos decisórios. Porém, a diversidade de interesses e a fragilidade nas relações de representação comprometem a qualidade de participação dessas vinte e quatro cadeiras.

Com relação à sociedade civil é evidente que o conselho não é um local para a participação das massas, e sim daqueles que estão organizados. Nesse sentido, alguns autores entendem que a sociedade civil organizada deveria dar conta de representar todos os indivíduos de forma igualitária, mas essa é uma interpretação equivocada, pois cabe ao Estado esse papel (ABER; KECK, 2008). O Estado eleito democraticamente tem obrigações com a igualdade de direitos de todos os cidadãos e se os conselhos falham em não representar as massas - o cidadão comum que não é organizado - os membros indicados pelo poder público que deveriam ser responsabilizados (ABER; KECK, 2008).

Essa abordagem é intrigante, não há como desconsiderar que existe pressão política e relações de poder que não permitem que o Estado "naturalmente" represente os interesses daqueles excluídos e hegemonizados ou da comunidade política como um todo, porém precisamos avançar essa negação, inclusive teórica, de que o Estado democrático não possa defender os interesses dos menos favorecidos (ABER; KECK, 2008). O poder público não é apenas um mediador pacífico de interesses, ele tem uma dinâmica própria e um caráter plural, possui grupos que geram seus projetos e procuram parceiros e aliados entre outros grupos com interesses convergentes no poder público e na sociedade civil (ABER; KECK, 2006; MASSARDIER, 2006).

A postura do poder público permite que os processos concorrenciais na APA BororéColônia acabem não contemplando os interesses dos moradores locais, pois são desenvolvidos por empresas externas, respaldadas em planos e documentos construídos por gestores públicos igualmente sem forte relação com a comunidade local. Um exemplo prático refere-se à já mencionada compensação ambiental advinda da construção do trecho Sul do Rodoanel Metropolitano Mário Covas. Neste contexto foram criados quatro Parques Naturais Municipais ${ }^{78}$ que estão com os portões fechados por não contarem com recursos financeiros e humanos. Antes da criação das UC's a comunidade local usava as referidas áreas para lazer (RAIMUNDO, et al., 2010), atualmente há uma grande contradição,

\footnotetext{
${ }^{78}$ Parques Naturais Municipais Jaceguava, Bororé, Itaim e Varginha (SÃO PAULO, 2012).
} 
impedindo tanto o uso original, que passou a ser criminoso, quanto o cumprimento do objetivo para o qual as áreas foram criadas.

A questão da representação é muito importante e o Brasil ainda está transitando de uma lógica autoritária para uma lógica democrática, um processo que trouxe avanços, mas ainda é muito recente. Embora do ponto de vista de modelos teóricos e expectativas preconizadas pelos estudiosos os conselhos tenham gerado desapontamentos, eles são importantes para desenvolver relações fecundas (LANE e MAXFIELD apud ABERS; KECK, 2008) entre indivíduos que provavelmente não iriam se relacionar de outra forma, permitindo novas práticas e novos procedimentos, além de serem arenas para debate e a tomada de decisão (ABERS; KECK, 2008).

Outro conceito da ciência política que auxilia na compreensão de aspectos da política pública que influenciam os conselhos gestores de unidades de conservação é a construção da agenda (KINGDON, 2006). A percepção de um problema é uma construção social, ele tem de ser reconhecido como tal pelas partes envolvidas e, neste sentido, quando os tomadores de decisão reconhecem a situação como um problema é que o problema de fato passa a existir (KINGDON, 2006). A partir da agenda alguns temas são priorizados pelo poder público em detrimento de outros (KINGDON, 2006). O controle da agenda geralmente é feito pelos agentes públicos (HOLMES; SCONNES apud ALONSO; COSTA, 2004; ABERS; KECK, 2008)

No conselho gestor da APA Bororé-Colônia, não é diferente. O controle da agenda do conselho é realizado pela Secretaria do Verde e do Meio Ambiente, personificada no gestor da unidade de conservação. Parece que os conselheiros não entendem como o controle da agenda é importante para levarem o reconhecimento dos seus problemas ao poder público. Ocasionalmente sugerem a inclusão de algum assunto na pauta que, por conta da postura aberta à participação por parte do gestor, acaba por ser incorporado. Embora o órgão gestor seja o protagonista da gestão da APABC e deva contribuir efetivamente na construção da agenda, pois é o responsável em primeira instância pelo cumprimento dos objetivos da unidade de conservação, entende-se que esta atribuição não deve the caber de modo exclusivo, sendo fundamental que haja participação e autonomia dos demais conselheiros em sua construção. 
Ao olharmos para o passado conseguimos entender um pouco melhor a realidade atual. A bibliografia aponta que existe uma diferença entre os processos deliberativos utilizados nos Estados Unidos e Europa, e aqueles utilizados na América do Sul, enquanto que nos países do hemisfério Norte a sociedade civil pleiteou a criação de mecanismos deliberativos, no Sul estes surgiram a partir de negociações entres ONGs locais e internacionais que buscavam induzir segmentos marginalizados à participação (HOLMES; SCOONES apud ALONSO; COSTA, 2004). Desta indução à participação derivam problemas e limitações; não há como garantir que os estratos superiores da hierarquia social não controlem o processo deliberativo; assim como não há como garantir sua legitimidade, ou seja, que os participantes percebam a influência de sua participação na concepção das políticas públicas (ALONSO; COSTA, 2004).

Os "burocratas de nível de rua" (MEYERS, VORSANGER; 2010) e sua respectiva discricionariedade (SUBIRATS, 2006) são os próximos conceitos oriundos das ciências políticas que contribuem na compreensão de feitios das políticas públicas que interferem no funcionamento dos conselhos gestores de unidades de conservação. Estes conceitos tratam do poder que o administrador público tem de interferir no processo de participação e deliberação. Os "burocratas de nível de rua" são aqueles funcionários públicos que estão na linha de frente com os cidadãos, são os responsáveis pela execução das políticas públicas que os cidadãos utilizam podendo interferir no processo (MEYERS; VORSANGER, 2010). Esse poder é chamado de discricionariedade, e ela existe quando o funcionário, dentro das normas legais estabelecidas, pode escolher entre alternativas de ação (HAM; HILL apud SUBIRATS, 2006).

Desde sua implantação a APA Bororé-Colônia já teve seis gestores ${ }^{79}$, e em janeiro de 2015, durante este estudo, observou-se uma troca de gestores na unidade de conservação. A discricionariedade do gestor talvez tenha incomodado ao poder público e a alguns atores sociais hegemônicos, que usaram seus poderes, possivelmente, como respostas de retaliação, substituindo aquele servidor com base em uma decisão top down (fato), imposta por pressão política para a Secretaria do Verde e do Meio Ambiente, que não partiu ou considerou a posição do conselho gestor da APA Bororé-Colônia ou a opinião do funcionário

${ }^{79} \mathrm{Em}$ ordem cronológica os gestores da APA Bororé-Colônia foram Rodrigo Martins dos Santos, que foi substituído por Leandro Caetano, em seguida Luiz Sertório, Felipe Spina Avino, Diego Lustre Gonçalves e, atualmente, Alice Maria Calado. 
em questão. Embora essa alternância tenha incomodado profundamente muitos conselheiros pela descontinuidade, ela não gerou nenhuma mobilização específica para reivindicar a manutenção do gestor deposto, que foi apontado como o mais democrático entre todos os gestores que já haviam passado pela APABC. Talvez o fato da nova gestora ser "alguém da casa" ${ }^{80}$, que os conselheiros já conheciam e pela qual nutriam boas expectativas, somado ao fato do gestor anterior ter sido realocado para o Parque Natural Municipal do Itaim (inserido dentro da $A P A B C$ ), tenha amenizado o sentimento de descontinuidade que os acometeu.

Embora ainda embrionária e muito distante de ser esgotada, a reflexão teórica proposta neste capítulo trouxe um pano de fundo que permitiu olhar para aspectos das políticas públicas que interferem no funcionamento e na governança do conselho gestor da APA Bororé-Colônia. Percebeu-se que a grande contribuição do conselho é na articulação entre os atores que atuam no território e que se fazem representados naquele fórum, porém os frutos dessa articulação dependem muito da representatividade desses conselheiros e sofrem consequências dos burocratas de nível de rua e de sua discricionariedade. O conselho gestor da APABC pode estimular a ampliação da sua rede a partir do estímulo a novas cooperativas, novos coletivos, novos ambientalistas, pessoas comprometidas com uma forma de desenvolvimento coerente e convergente com os objetivos de gestão da APABC. O controle da agenda é muito importante para a validação por parte do poder público de um determinado problema social, porém os conselheiros da APA Bororé-Colônia ainda não enxergaram sua importância dentro do colegiado.

Factualmente, existem fatores que jogam negativamente no funcionamento de uma "boa" governança (GRAHAM; AMOS; PLUMPTRE, 2003) a partir dos conselhos gestores de unidades de conservação, alguns devido a atos discricionários do Estado e outros inerentes ao próprio desenvolvimento de nossa sociedade e das pessoas. Como bem colocou Tatagiba (2005, p.209) "(...) os conselhos são também espelhos que refletem as dimensões contraditórias de que se revestem nossas experiências democráticas recentes". Os debates sobre a democracia contemporânea continuarão animados ainda por muito tempo pela discussão acerca da efetividade de participação quanto à democratização dos processos de

${ }^{80}$ Alice Maria Calado antes de assumir a gestão da APA Bororé-Colônia era gestora do Parque Natural Municipal do Itaim. 
gestão e a melhoria na qualidade dos seus resultados (TATAGIBA, 2005). A partir de todo o referencial teórico e conceitual colocado, o próximo capítulo aprofunda a análise sobre a governança no conselho gestor da APA Bororé-Colônia com base nos princípios e critérios de "boa" governança propostos por Graham, Amos e Plumptre (2003). 


\section{CAPÍTULO 3}

\section{A governança em análise no conselho gestor da APA Bororé-Colônia}

Não há a intenção de se apontar o que é certo e o que é errado na governança do conselho gestor da APA Bororé-Colônia, apenas analisar a conjuntura a luz da teoria apontada. O contexto da unidade de conservação, sua história, a cultura do seu povo, as questões legais, sua capacidade, entre outros fatores, condicionam o que pode ser adequado em sua realidade. Com o passar do tempo, as iniciativas que hoje existem na área protegida podem evoluir para um novo tipo de governança, afinal a gestão é um processo.

As informações relatadas nesse capítulo são fruto da sistematização dos documentos consultados, das entrevistas realizadas e dos demais percursos metodológicos que guiaram este estudo. A análise realizada é pautada pelos princípios de "boa" governança e seus respectivos critérios propostos por Graham, Amos e Plumptre (2003) e sofre influência dos demais referenciais teóricos apresentados.

\subsection{Legitimidade e voz}

Sem dúvida esse é um princípio bem complexo de ser analisado. Alcançar a legitimidade e voz é avançar na democracia. Depende de: forças de segurança politicamente neutras; partidos políticos com bom funcionamento; meios de comunicação independentes; sociedade civil mobilizada; respeito ao direito dos povos indígenas e comunidades tradicionais; instituições pautadas no respeito pelos direitos humanos incluindo a participação equitativa das mulheres; combate aos riscos de emersão da tirania ou do populismo; promoção da tolerância e a aceitação de vozes dissidentes (GRAHAM; AMOS; PLUMPTRE, 2003). Apesar de estes fatores estarem muito longe do alcance dos gestores e conselheiros eles são fundamentais na constituição da conjuntura que dá o pano de fundo para a governança em unidades de conservação.

Pautados pelo reconhecimento das populações indígenas e tradicionais e na redução dos conflitos, ao longo das últimas décadas os órgãos gestores das áreas protegidas estão vivenciando a incorporação de diversos atores interessados na gestão de seus parques e 
reservas (GRAHAM; AMOS; PLUMPTRE, 2003). Inseridos neste cenário, outros atores têm tomado a frente na gestão de alguns desses espaços sem ter um regime de governo formal (GRAHAM; AMOS; PLUMPTRE, 2003). O quadro 7, a seguir, organiza as diferentes formas de governança que podem ser concebidas no contexto da gestão das áreas protegidas.

Quadro 7: Tipos de governança para áreas protegidas

\begin{tabular}{|c|c|c|c|c|c|c|c|c|c|}
\hline \multicolumn{10}{|c|}{ Diferentes formas de gestão das áreas protegidas } \\
\hline \multicolumn{3}{|c|}{ Gestão governamental } & \multicolumn{2}{|c|}{$\begin{array}{l}\text { Gestão entre } \\
\text { vários atores }\end{array}$} & \multicolumn{3}{|c|}{ Gestão privada } & \multicolumn{2}{|c|}{$\begin{array}{l}\text { Gestão por } \\
\text { indígenas e } \\
\text { comunidades } \\
\text { tradicionais }\end{array}$} \\
\hline 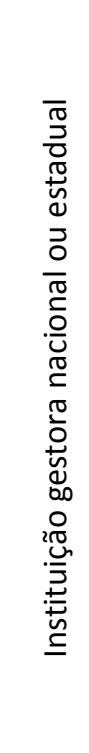 & 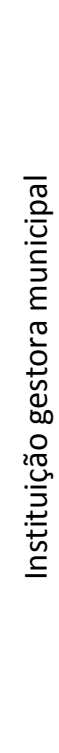 & 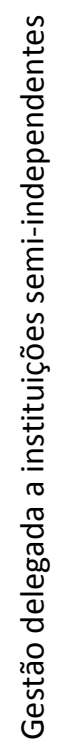 & 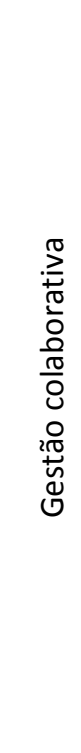 & 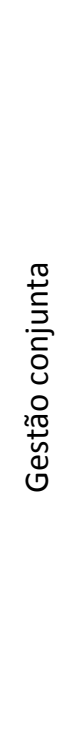 & 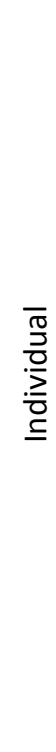 & 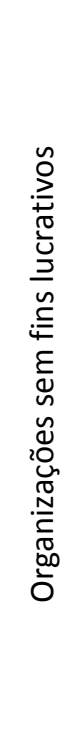 & 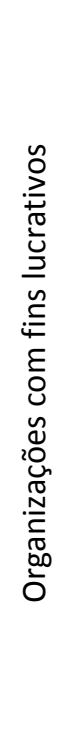 & 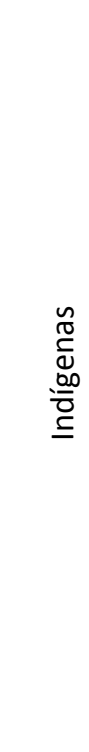 & 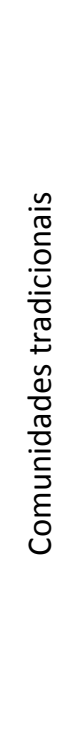 \\
\hline
\end{tabular}

Fonte: Graham; Amos; Plumptre (2003). Traduzido pela autora.

O contexto é muito importante na escolha por um ou outro tipo de governança. Um regime de gestão é dinâmico, não é um estado fixo (GRAHAM; AMOS; PLUMPTRE, 2003). Essa concepção de tipos diferenciados de gestão é complementar a categoria de unidade de conservação a que for aplicada, afinal cada categoria de UC possui conjunturas que permitem alguma(s) forma(s) de gestão na medida em que inviabiliza outras (GRAHAM; AMOS; PLUMPTRE, 2003).

Outra abordagem de olhar para o fortalecimento local é através da variedade de iniciativas agrupadas sobre a ideia de descentralização (GRAHAM; AMOS; PLUMPTRE, 2003). Para o PNUD há quatro abordagens para a descentralização (GRAHAM; AMOS; PLUMPTRE, 2003). A primeira denomina-se devolução e consiste em devolver o poder para as unidades locais autônomas de governo de modo que as autoridades centrais acabem por influenciá- 
las muito pouco ou praticamente nada (GRAHAM; AMOS; PLUMPTRE, 2003). A segunda é chamada de delegação e se refere à transferência de poder de decisão e de autoridade administrativa para unidades locais semi-independentes, que, em geral, não possuem autonomia financeira e que podem estar legalmente ligadas a um governo central (GRAHAM; AMOS; PLUMPTRE, 2003). A terceira é denominada desconcentração e se refere em geral a postos avançados do governo central, com pouca autoridade (GRAHAM; AMOS; PLUMPTRE, 2003). A quarta se chama desinvestimento, e consiste na transferência de funções administrativas e de planejamento para instituições voluntárias, privadas ou não governamentais (GRAHAM; AMOS; PLUMPTRE, 2003). A seguir estão os critérios que derivaram dessa conceituação aplicados ao contexto do conselho gestor da APA BororéColônia.

\section{Existência de contexto de suporte democrático e de direitos humanos}

A existência de contexto de suporte democrático pode ser verificada a partir de: instituições democráticas baseadas na eleição livre e em um sistema multipartidário viável; respeito aos direitos humanos como liberdade de expressão, de associação e de religião; inexistência de discriminação baseada em raça, cor ou religião; promoção da tolerância e da harmonia social; e respeito aos direitos dos povos indígenas (GRAHAM; AMOS; PLUMPTRE, 2003). O Brasil ainda está evoluindo em sua democracia, já alcançamos as eleições livres, mas ainda enfrentamos outros desafios, como partidos políticos que não apresentam um bom funcionamento; grandes veículos de comunicação que embora sejam independentes atendem aos interesses de grupos hegemônicos; comunidades tradicionais e povos indígenas que enfrentam grandes empecilhos para fazerem valer seus direitos previstos em nossas leis, entre tantos outros obstáculos.

Nas próximas linhas tentar-se-á transpor essa concepção de existência de suporte democrático para o conselho da APA Bororé-Colônia. O conselho prevê a existência de suporte democrático na medida em que permite que os representantes de um mesmo segmento da sociedade civil se candidatem para aquela cadeira que desejam ocupar, sendo a entidade vencedora escolhida por votação entre seus pares ${ }^{81}$. Qualquer coletivo tem o

\footnotetext{
${ }^{81}$ De acordo com o Artigo 4ํ do Regimento Interno do Conselho gestor da APA Bororé-Colônia.
} 
direito de se organizar e pleitear representação no conselho. Na prática, entretanto, esse sistema encontra-se inoperante devido à ausência de instituições interessadas em ocupar as cadeiras do conselho. Há baixa renovação no quadro de conselheiros, o gestor da unidade de conservação tem de buscar os representantes na sociedade civil.

O contexto de livre associação também é difícil de ser apropriado por setores menos articulados que tem dificuldade em lidar com os processos burocráticos de formalização e também não possuem essa cultura formal de associação. As massas não participam dessas organizações da sociedade civil. A participação é limitada a um certo número de pessoas e neste cenário emergem algumas lideranças. Não havendo muito interesse da sociedade para a participação a renovação das lideranças é muito baixa.

As organizações da sociedade civil que ocupam cadeiras no conselho não são democráticas e baseadas na eleição livre. Além do fato de existirem atores de mercado cidadãos que agem em prol de interesses privados - e atores públicos - cidadãos que pautam sua atuação na busca do controle social sobre as políticas públicas com interesses sociais (FRACALANZA, 2015) 82 -, há de se refletir sobre qual é o papel de um representante e como ele chega a tal forma perante o grupo (ABERS; KECK, 2008). Haver ou não legitimidade e identificação depende muito de como a sociedade compreende o processo de escolha de um representante e da qualidade desta relação, em geral não é possível se mensurar em nome de quem esses representantes estão falando (ABERS; KECK, 2008). Na troca entre representantes e representados deve haver autorização, troca, informação, suporte, subsídio, prestação de contas e controle (ABERS; KECK, 2008).

Não foi possível saber como se dá essa troca entre os conselheiros e aqueles que eles representam, pois essa é uma relação muito complexa que demanda outro tipo de análise para ser compreendida. Porém, evidenciou-se que as pessoas tem dedicado pouco tempo à participação, à vida política. Há de se considerar também que o conselho, por mais que tenha uma composição que abarca boa parte da diversidade de atores sociais presentes na APA Bororé-Colônia, restringe as participações, e o governo deveria complementar aqueles

\footnotetext{
82 Dr Ana Paula Fracalanza, Professora Drạ Titular da Universidade de São Paulo do curso de Pós-Graduação em Mudança Social e Participação Política (PROMUSPP) da Escola de Artes, Ciências e Humanidades. Fala proferida durante a aula de Tópicos Aplicados em Gestão Participativa. Universidade de São Paulo. 12/05/2015. PROMUSPP/EACH/USP.
} 
que estão ausentes nas representações, pautando-se na complexidade do todo, no balizamento do conflito e na igualdade de direitos (ABERS; KECK, 2008.). Porém as dificuldades de materialização dessa concepção são reais e tem grandes dimensões.

Com relação à liberdade de expressão, nas reuniões do conselho gestor da APA Bororé-Colônia todas as pessoas tem direito a voz, embora apenas os conselheiros tenham direito a voto. Em um espaço onde se busca por meio do diálogo a exposição das partes e a construção de uma alternativa que seja a melhor naquele momento, a que atenda a maior parte dos interessados, o voto é uma alternativa adotada em último caso, pois ele tem muita conotação de vitória e derrota. Quando há uma votação sempre há o sentimento de que uns foram vencedores enquanto outros foram perdedores. Já quando há consentimento, ou seja, quando se constrói coletivamente a melhor proposta possível naquela conjuntura o sentimento é diferente, não há aquela polaridade entre vitória e derrota. Neste sentido, o direito a voz é muito importante e tem sido garantido no conselho gestor da APA BororéColônia. Entretanto, se percebe que a promoção desse direito está muito ligada à postura do gestor da APA que preside o conselho, o que levanta o questionamento, por hora sem resposta, de quanto realmente que o conselho se apropriou do direito a voz? Essa apropriação parece ser baixa, talvez porque os conselheiros não a enxerguem como uma oportunidade, já que dela não derivam ganhos imediatos, dada a dificuldade de materialização do que é deliberado no conselho, como será abordado com mais profundidade no tópico seguinte.

Questões relativas à discriminação de raça, cor ou religião não foram observadas, parecem não fazer parte da realidade do conselho gestor da APA Bororé-Colônia, todos tem os mesmos direitos e são respeitados da mesma forma. Há um estímulo para o desenvolvimento da agricultura orgânica que dialoga com a promoção do respeito ao direito dos povos tradicionais. Essa abordagem, porém, é muito mais ampla, e esse estímulo algo muito tímido frente ao seu potencial.

\section{Grau apropriado de descentralização na tomada de decisões nas unidades de conservação}

O grau máximo de descentralização na tomada de decisões nas unidades de conservação prevê que qualquer decisão seja feita em nível local, através de estruturas que: 
prestem contas à população, trabalhem o poder e a capacidade necessários ao desempenho de suas funções, trabalhem dentro de algumas condições como parâmetros ambientais mínimos visando objetivos mais amplos de interesse nacional e internacional (GRAHAM; AMOS; PLUMPTRE, 2003).

O sistema de gestão proposto no município de São Paulo adota o princípio de gestão descentralizada e participativa através da criação de um conselho gestor para cada APA municipal, que promove a articulação entre o governo e os demais setores envolvidos. Porém, na prática, apesar da existência de um conselho gestor deliberativo, a gestão da APA Bororé-Colônia não está descentralizada. Suas estruturas de prestação de contas à população são praticamente inexistentes, como será exposto adiante no princípio que trata da prestação de contas. A estrutura da SVMA não está dotada da capacidade necessária para a gestão da UC, como será exposto no princípio do desempenho, e tem enfrentado dificuldades no atendimento de suas demandas por outras pastas do poder público no que tange a APABC. Existe apenas um funcionário ligado a APA Bororé-Colônia e ao seu conselho que é o gestor da UC. Em geral o que é deliberado no conselho da APABC necessita de outros atores do poder público para se materializar, demandando uma articulação política que vai além dos representantes presentes naquele fórum, empreitada em que tanto a SVMA quanto os conselheiros estão enfrentando grandes obstáculos.

Dentro dos tipos de governança apontados pelos autores Graham, Amos e Plumptre (2003), sintetizados no quadro 7, nas páginas anteriores, a APA Bororé Colônia e seu conselho gestor estão na gestão governamental, realizada por um governo municipal. Embora a APA seja uma categoria de unidade de conservação com grandes características de ocupação humana na qual faria todo sentido uma gestão pelas comunidades locais, a realidade da $A P A B C$ não aponta para esse cenário. O mais palpável seria, na medida em que houvesse amadurecimento da "boa" governança do seu conselho gestor, a gestão da APABC evoluir para a gestão compartilhada entre vários atores, de modo que, de forma conjunta, ou colaborativa com a SVMA, coletivos da sociedade civil organizada de atuação local pudessem gerenciar alguns projetos específicos no território. As Câmaras Técnicas do conselho gestor da APABC tem o potencial de serem espaços legitimados dentro do colegiado para que a sociedade civil possa coordenar os trabalhos e assumir um papel de responsabilidade e autonomia sobre os projetos. 


\section{Gestão participativa nas tomadas de decisão da unidade de conservação}

A gestão participativa nas tomadas de decisão da unidade de conservação precede da inclusão de todas as partes afetadas, especialmente as comunidades locais e os povos indígenas (GRAHAM; AMOS; PLUMPTRE, 2003). Existe paridade entre poder público e sociedade civil na composição das cadeiras do conselho gestor da APA Bororé-Colônia. Entretanto, essa delimitação de cadeiras não garante que a paridade se reflita no cotidiano do conselho. A primeira questão que se coloca é quanto à composição da sociedade civil; dentro desta temos os atores de mercado e os atores públicos, os primeiros com interesses privados e os segundos com interesses sociais (FRACALANZA, 2015). Neste sentido, não podemos esperar que a sociedade civil represente a diversidade da sociedade, em especial dos excluídos e hegemonizados. Recorrendo a reflexão que nos trouxeram Abers e Keck (2008) o poder público tem a responsabilidade de garantir a igualdade entre todos os cidadãos, e ao se transpor essa abordagem para o conselho, cabe ao poder público representar os não representados, os hegemonizados.

Há uma gama muito diversa de usos e concepções no território da APA BororéColônia e o poder público nem de longe consegue representar no conselho gestor da APABC os não representados, os hegemonizados. As subprefeituras, tanto de Capela do Socorro quanto de Parelheiros são ausentes, tem uma frequência muito baixa nas reuniões. $E$ a maior parte dos representantes das outras instituições do poder público não qualifica o debate, não conseguem fazer a ponte entre a entidade que representam e a APABC, salvo raras exceções, a exemplo do conselheiro da Empresa Metropolitana de Água e Energia S.A. (EMAE) que sempre posiciona a entidade que representa deixando clara suas atribuições, competências, limitações e seu posicionamento frente aos conflitos. Esse aspecto é muito importante, por conta das características fundiárias da unidade de conservação o poder público indicado na divisão das cadeiras efetivamente tem grandes atribuições de atuação no território da $A P A B C$ e poderia implicar um ritmo mais qualitativo para as reuniões do conselho, contribuindo no encaminhamento dos conflitos e problemas que ali emergem e muitas vezes ficam sendo debatidos durante muitas reuniões sem grandes avanços. 
Outra reflexão diz respeito à capacidade de participação de cada conselheiro. Sem dúvida as pessoas com menos escolaridade tem maior dificuldade em construir sua argumentação. Em um fórum baseado no diálogo, não é possível considerar que estes cidadãos estão nas mesmas condições de participar que outros cidadãos mais escolarizados. Há uma preocupação por parte da gestão de que a linguagem usada no conselho seja a mais simples possível, evitando o uso de termos técnicos e de difícil compreensão. Também há um empenho em oportunizar para os conselheiros vagas em cursos promovidos pelo Departamento de Educação Ambiental da $\mathrm{SVMA}^{83}$ em temas que contribuam para sua formação. Mesmo com estes esforços ainda existe um grande caminho a trilhar para que os representantes das classes populares, historicamente hegemonizados, tenham as mesmas condições de participação que outros representantes.

Há de se considerar também, que entre grupos organizados e os "cidadãos comuns" há uma diferença de comportamento e opiniões: enquanto os primeiros têm opiniões definidas, os outros têm dificuldades em colocar seus argumentos (ALONSO; COSTA, 2004). Para haver legitimidade é necessário que haja qualidade na relação entre representantes e representados, o que implica em autorização; troca; informação e suporte; subsídio; prestação de contas e controle, conforme citado anteriormente (ABERS; KECK, 2008). Essa relação de representação é muito importante e muito frágil, como consequência quando os membros do conselho não conseguem atingir a atenção do seu público eles tendem a agir de acordo com seus interesses pessoais (ABERS; KECK, 2008).

Outro desafio para a gestão participativa nas tomadas de decisão diz respeito à capacidade de renovação e de atrair o interesse social que o conselho possui. Para Jacobi, "o desinteresse e a frequente apatia da população com relação à participação são generalizados, resultado do pequeno desenvolvimento da sua cidadania e do descrédito nos políticos e nas instituições" (JACOBI, 2004, p. 277). Corroborando a assertiva deste autor, sentimos presencialmente que a sociedade parece não dispor de tempo ou se desinteressa por discutir políticas públicas, pois, conforme mencionado no capítulo 1.7., durante todo o

\footnotetext{
${ }^{83}$ A UMAPAZ oportuniza com frequência vagas em cursos que contribuem na formação dos conselheiros. Durante a pesquisa, nas reuniões do conselho foram oferecidas vagas no 2 o Curso de Meio Ambiente do Conselho para as APAs Bororé-Colônia e Capivari-Monos, no minicurso Conhecendo as responsabilidades por ações lesivas ao meio ambiente, no Curso de Legislação Ambiental e Fiscalização em Áreas Protegidas e no Curso de Gestão Pública Socioambiental: Instrumentos de Políticas Urbanas e Aplicações na Região Sul da Cidade-Macrosul.
} 
período da pesquisa o conselho gestor da APA Bororé-Colônia não teve representantes para ocupar as cadeiras de representante e suplente destinada aos pescadores e a cadeira de suplente destinada aos agricultores. Não houve, espontaneamente, novos representantes e o gestor teve de buscar novos conselheiros na sociedade civil sem sucesso. Os pescadores não deixaram de frequentar o conselho porque sua demanda foi sanada, mas porque ela não repercutiu no fórum como eles esperavam. Esse desinteresse e essa apatia da sociedade influenciam no esvaziamento do potencial que essas instâncias de participação possuem, mas são fato e precisam ser enfrentadas. Há um monte de leis para garantir a participação da sociedade na gestão ambiental, mas o fato é que o poder público não pode esperar que as classes historicamente alijadas dos processos políticos tenham as mesmas condições e interesses em participar da gestão pública que os outros cidadãos. Há de se empenhar mais energia com essas pessoas, afinal elas já largaram atrasadas.

Para ampliar esse poder de ação coletiva é preciso qualificar a representatividade e deter mais capital social; é necessário mais organização coletiva da população local, existência de fortes lideranças locais, empoderamento, organização e articulação desses cidadãos com outros atores que influenciam em seus territórios (PUTNAM, 1996). Isto tem um custo, e o poder público tem de assumi-lo para ajudar no desenvolvimento social. $A$ curto prazo, no mínimo, deve-se custear o deslocamento dos conselheiros da sociedade civil, oferecer-Ihes alimentação e quiçá, em uma situação de avançada mentalidade e legislação, custear-lhes o período de trabalho desprendido com a reunião a partir da implantação de estratégias que permitam que os contratantes dispensem seus contratados para que eles possam participar deste tipo de colegiado. A longo prazo, a educação social e política é um caminho fundamental e indispensável na busca por uma participação qualitativa da sociedade nas políticas públicas ambientais.

Participação dos cidadãos ocorrendo em todos os níveis de tomada de decisão relacionados à unidade de conservação

Outro critério para a legitimidade e voz é a participação dos cidadãos ocorrendo em todos os níveis de tomada de decisão relacionados à unidade de conservação (legislação, planejamento de sistemas, criação e implantação de UCs, planejamento da gestão, operação) com ênfase no nível local e na participação equitativa de homens e mulheres (GRAHAM; AMOS; PLUMPTRE, 2003). Trata-se de um critério complexo e longínquo, que 
deve ser observado como um processo, fato que o curto período de análise deste estudo não contempla, portanto, a análise realizada é limitada.

Existe por parte da gestão da APA Bororé-Colônia uma mentalidade convergente com esse critério. Embora o governo seja omisso em vários aspectos quando olhamos para a unidade de conservação; com insuficiência de recursos humanos e ausência de orçamentos, a presença de servidores públicos na Secretaria do Verde e do Meio Ambiente que levam a pauta da participação social debaixo do braço é um aspecto fundamental na busca pela participação dos cidadãos em todos os níveis de tomada de decisão relacionados à UC, além do fato de seu conselho ter sido legalmente instituído como deliberativo. Os gestores que passaram pela APA Bororé-Colônia no período deste estudo, no limite da discricionariedade, sempre buscaram fomentar a participação social na gestão ambiental pública.

Não existia na APA Bororé-Colônia uma organização social de gestão do território anterior ao conselho ${ }^{84}$, nesse sentido esse fórum é importante pelo poder potencial que possui de deliberação na gestão ambiental pública e por ser uma arena onde se encontram diversos atores que estabelecem diferentes relações com a unidade de conservação. A rede que se formou a partir do conselho vem sendo apropriada pelas comunidades locais em prol de seu fortalecimento e proteção, ainda que lentamente. A APABC sofre grandes projetos concorrenciais por atores externos que não possuem territorialidade alguma com a área protegida, caso das grandes empreiteiras, construtoras. A comunidade precisa amadurecer para que consiga impor as soluções que partam de seu âmago. Essa organização social ainda é incipiente e o conselho tem contribuído, ainda que modestamente, para seu aprimoramento na medida em que fomenta o engajamento de alguns atores. Embora sejam poucos, são estes atores que através desta rede tem apresentado potencial para materializar objetivos e resistir aos domínios hegemônicos. Como exemplo desta abordagem, durante o estudo foi observado que um coletivo da sociedade civil chamado IMARGEM, atuante na área da APABC, ocupou uma das casas da EMAE que ficam nas margens da Represa Billings, no bairro do Bororé, para sediar as instalações da organização e ser um espaço de uso comunitário. A articulação existente entre os atores do conselho

\footnotetext{
84 É claro que existiam organizações sociais como associações de bairro e organizações não governamentais locais com atuação no território e muito importantes na busca por implantarem suas demandas nas agendas do poder público, mas se tratam de iniciativas mais locais.
} 
gestor da $A P A B C$ foi fundamental para que se legitimasse a ocupação desse espaço pelo coletivo e para que não fosse exigida uma reintegração de posse à base de força policial.

Como foi colocado no capítulo que trata da história da APA Bororé-Colônia, a ocupação humana naquela região se deu por pessoas de várias origens. Não se trata de um povo que há centenas e centenas de anos ocupa aquele local com relativo isolamento e um modo de vida tradicional. Mas como já foi discutido ao longo deste texto, o entendimento de comunidade local ou tradicional que se aplica a $A P A B C$ está muito mais ligado ao referencial e a relação que as pessoas estabelecem com o território do que com a permanência naquele local ao longo de muitas gerações. Ainda mais no caso de uma unidade de conservação inserida no meio de uma metrópole que procura manter suas características rurais, não há como compreendê-la como uma redoma, os processos sociais de interesses internos e externos, de assuntos ligados ao mundo rural e urbano, aparecem cotidianamente na APABC. A tradicionalidade não é estática, ela acompanha a movimentação da comunidade.

Olhando para outro aspecto da participação, como será descrito adiante, no capítulo que trata da equidade, a criação de novas unidades de conservação na APA Bororé-Colônia não foi um processo qualitativamente participativo. A participação dos cidadãos em todos os níveis da tomada de decisão relacionados à unidade de conservação ainda é muito frágil e precisa amadurecer muito no conselho gestor da APABC. Sem dúvida esse critério é revestido de muita importância, e a conjuntura dos fatores apresentados nesse texto, que tratam das limitações de participação e de representatividade no contexto exposto da APA Bororé-Colônia, influenciam muito em sua construção.

\section{Existência de associações civis e mídias independentes}

A existência de associações civis e mídias independentes que monitorem e possam exercer um contrabalanço no exercício do poder decisório das lideranças políticas e dos gestores da UC é um critério importante na construção da legitimidade e voz (GRAHAM; AMOS; PLUMPTRE, 2003). É reconhecido em estudos que tratam da accountability social na America Latina que existem diversas iniciativas guiadas por movimentos sociais, Organizações Não Governamentais, associações civis e mídia independente pautadas pela 
preocupação em melhorar a transparência e a prestação de contas da ação governamental (VASCONCELOS, 2009)

Há uma mudança cultural em curso onde o representado está deixando seu papel passivo em prol da adoção de um papel de monitoramento ativo, contando com o estabelecimento de mecanismos e recursos que o auxiliem nesse acompanhamento dos representantes políticos e servidores públicos (VASCONCELOS, 2009). Porém, a América Latina ainda encontra muitos problemas e desafios em seus diversos mecanismos de controle do poder político; “(...) ainda não existe uma rede de agências capazes de controlar e castigar as ações que possam ser qualificadas como ilegais ou corruptas" (O'DONNELL, apud VASCONCELOS, 2009).

No contexto da APA Bororé-Colônia não é diferente. Existem Organizações Não Governamentais, movimentos sociais e associações civis que fazem o uso da internet e das redes sociais como mídias para tomar contato com a população e cobrar o poder público. Porém, ainda encontram muitos desafios para ampliar sua atuação e conseguir resultados efetivos de prestação de contas. Vasconcelos (2009) acredita que apenas articulados esses setores podem encontrar maiores resultados.

Considerando as já expostas limitações à participação nos conselhos gestores de UCs, o conselho gestor da APA Bororé-Colônia não conta com uma forte rede articulada entre associações civis e mídia independente que exerça forte influência no poder decisório das lideranças políticas que atuam na região. Haja vista os desdobramentos do trecho sul do Rodoanel Metropolitano Mário Covas.

Já no que tange a gestora atual da APA Bororé-Colônia e ao gestor anterior, considerando o limite da discricionariedade que permeia as suas atuações profissionais, ambos são servidores dedicados às questões das minorias e muito abertos ao diálogo com a sociedade civil, estando muito sujeitos a influência das associações civis. O problema parece estar na organização do governo Secretaria do Verde e do Meio Ambiente na qual eles atuam em diante, praticamente blindada para essas organizações. É necessário que essa postura de promoção à participação social seja institucionalizada, levada como política de capacitação a todos servidores públicos que eventualmente gerenciem a unidade de 
conservação, a despeito da formação e do perfil do gestor. Mas, como? Sem dúvida essa é uma questão relevante que merece reflexão.

\section{Alto nível de confiança entre os vários atores envolvidos no manejo da unidade de conservação}

A conjuntura apresentada e que ainda será exposta nas próximas linhas, em especial nos princípios de desempenho e de equidade, ajuda a construir a sustentação para a afirmação de que há grande fragilidade na confiança entre os atores envolvidos no manejo da APA Bororé-Colônia. Por se tratar de uma UC de uso sustentável, formada por terras públicas e privadas, a gestão do território da APABC é feita por diversos atores, sendo eles governamentais e não governamentais, em um nível que vai do nacional, passando pelo estadual e terminando no local. O Plano de Gestão da APA foi $13,68 \%$ concluído ${ }^{85}$, isso significa que dentre as ações planejadas no início da gestão, apenas 13,68\% foram levadas a cabo. O poder público poderia ter contribuído para que sua implementação fosse maior. Contudo, a sociedade com seu poder de pressão política pode e deve estar atenta ao desenvolvimento e à implementação de políticas públicas que a beneficiem e promovam a conservação da APA Bororé-Colônia.

\subsection{Direcionamento}

Como colocaram Graham, Amos e Plumptre (2003) este princípio é menos polêmico e seus benefícios são mais fáceis de serem compreendidos. A estabilidade que o direcionamento pode gerar é um aspecto muito positivo, pois deixa claro para as partes envolvidas o conjunto de parâmetros em torno dos quais será construída a confiança e estabelecidos os relacionamentos (GRAHAM; AMOS; PLUMPTRE, 2003). Há também uma relação constate entre o direcionamento e o planejamento; enquanto o primeiro oferece o ambiente e as condições para o segundo tomar lugar, é o planejamento que assegura que o direcionamento esteja imbuído de um contexto de melhoria contínua, não permitindo que ele fique estático (GRAHAM; AMOS; PLUMPTRE, 2003). O direcionamento também pode ampliar a capacidade de mobilizar recursos financeiros e humanos para a gestão da unidade

\footnotetext{
85 Informação divulgada na apresentação do Relatório Executivo 2014 durante reunião do Conselho gestor da APA Bororé-Colônia.
} 
de conservação, mas no ambiente político complexo de demandas concorrentes que vivemos geralmente se leva tempo para atingir essa mobilização (GRAHAM; AMOS; PLUMPTRE, 2003).

O tema da conservação ambiental tem ganhado maior relevância na medida em que se ampliam no contexto internacional as convenções, programas e documentos de orientação que o discutem. Paralelamente, também tem aumentado a percepção sobre a necessidade de se abordar de maneira integrada a conservação e o uso sustentável dos recursos naturais, ou seja, as áreas protegidas e as populações que as habitam. Neste contexto, houve oportunidade para emergirem também as categorias de áreas protegidas menos preservacionistas que ampliam as possibilidades de manejo (GRAHAM; AMOS; PLUMPTRE, 2003), caso da APA Bororé-Colônia, uma área menos restritiva.

\section{Conformidade com o direcionamento internacional relativo às unidades de conservação}

Como já foi observado no capítulo que trata dos aspectos ambientais da APA BororéColônia, ela é integrante da Reserva da Biosfera do Cinturão Verde (RBCV), que faz parte de um Programa Intergovernamental, o Programa Homem e Biosfera da Organização das Nações Unidas para a Educação, a Ciência e a Cultura (UNESCO). Mas na prática se há uma interface maior com este programa ela não é exposta nas reuniões do conselho gestor da APABC, aparentemente as discussões na RBCV são em outra escala, da qual não deriva nada aproveitável para o conselho e nem para a UC. As maiores parcelas das áreas protegidas do Estado de São Paulo e de sua capital inseridas na Reserva da Biosfera do Cinturão Verde são de gestão da Secretaria do Meio Ambiente do Estado de São Paulo (SMA) por meio do Instituto Florestal (IF) e da Fundação Florestal (FF). Sendo que cabe ao IF a presidência do Conselho da Reserva da Biosfera do Cinturão Verde.

Historicamente, quem detém o conhecimento sobre a gestão de UCs em São Paulo é o Instituto Florestal (IF) e a Fundação Florestal (FF), e assim é a Secretaria de Meio Ambiente do Estado de São Paulo (SMA) quem está mais próxima dos debates internacionais relativos às unidades de conservação. A experiência da Secretaria do Verde e do Meio Ambiente (SVMA) do município de São Paulo na gestão de UCs é recente e veio com a implantação das APA Capivari-Monos e Bororé-Colônia, em meados de 2000, bem como dos Parques Naturais 
Municipais instituídos na última década. Neste sentido, parece ser de bom alvitre haver uma aproximação da SVMA com a SMA, especialmente com a FF, para ampliar e qualificar esse direcionamento estadual, tendo em vista a conformidade com o direcionamento internacional. Inexiste uma política integrada entre as instituições, com objetivos conjuntos e ações integradas, embora exista uma articulação limitada a algumas situações pontuais. Boa parte dos gestores de ambos os órgãos governamentais se conhecem e têm relações de coleguismo, muitas vezes esse contato deriva do fato de orbitarem uma mesma rede em torno da questão da gestão das áreas protegidas. Porém, nos últimos anos, é reconhecido no meio técnico conservacionista que a FF passou por uma gestão cuja orientação era de reclusão, e não houve por sua parte tentativa de aproximação com a SVMA, a despeito do esforço dos gestores das UCs inseridas no extremo sul em manter, minimamente, uma relação.

\section{Existência de direcionamento legislativo}

O direcionamento legislativo, seja ele formalizado ou com regras tradicionais, deve indicar os propósitos e contar com critérios claros para as unidades de conservação, também deve indicar claramente a competência das autoridades em relação aos meios de gestão (instrumentos de governança), bem como estabelecer condições claras para que instituições viáveis administrem a UC, incluir exigências para que os cidadãos participem da tomada de decisão e é importante que seja elaborado na forma de proposições escritas (GRAHAM; AMOS; PLUMPTRE, 2003).

Transpondo a análise para os critérios de direcionamento apontados pelos autores Graham, Amos e Plumptre (2003) e aplicando-os ao conselho gestor da APA Bororé-Colônia; inicia-se a reflexão pela existência de direcionamento legislativo formalizado. A APA BororéColônia foi instituída pela Lei nำ14.162, de 24 de maio de 2006 (SÃO PAULO, 2006) que indica: sua relevância; seus propósitos; sua extensão; as atividades que não podem ser executadas em seu território; as atividades que precisarão de licenciamento ambiental cabendo manifestação do conselho gestor; condições da supressão da cobertura vegetal; condições da disposição de resíduos sólidos; condições do despejo de efluentes; a recuperação de assentamentos urbanos anteriores; o condicionamento da melhoria e 
adequação das estradas a aprovação do conselho gestor; a proibição da coleta de animais silvestres e da soltura de animais exóticos; condições para o uso e manejo do solo agrícola; a obrigatoriedade da existência de um programa de educação ambiental permanente; a instituição de um zoneamento geoambiental; como ocorrerá a gestão ambiental; condições do controle e da fiscalização; entendimentos sobre as infrações; como se darão as penalidades; a origem dos recursos financeiros; entre outras disposições transitórias e finais. Esta lei indica os propósitos e os critérios para a UC de maneira clara, além de iniciar também a tratativa sobre a competência das autoridades em relação aos meios de gestão (instrumentos de governança).

Avançando mais nesse ponto que trata da competência das autoridades em relação aos instrumentos de governança, em 25 de setembro de 2007 foi estabelecido o Regimento Interno ${ }^{86}$ do conselho gestor da APA Bororé-Colônia de acordo com a Lei Municipal n¹4.162/2006 que instituiu a APABC. O conselho tem uma série de atribuições, as quais devido a sua relevância merecem ser citadas:

Art. 2 - São atribuições deste conselho gestor:

I - estabelecer normas de interesse desta APA e acompanhar sua gestão;

II - estabelecer o Zoneamento Ambiental e o Plano de Manejo desta APA;

III - aprovar, no âmbito de sua competência, planos, programas e projetos a serem implementados nesta APA, ou a ela relacionados;

IV - aprovar, no âmbito de sua competência o zoneamento ambiental estabelecido no capítulo III da Lei Municipal 14.162/06;

$\mathrm{V}$ - manifestar-se, quando do seu interesse, quanto ao licenciamento referido no art. 70 da Lei no14.162/06;

VI - propor, quando necessário, a elaboração e a implementação de planos emergenciais;

VII - criar ou dissolver câmaras técnicas para tratar de assuntos específicos, competindo-Ihe indicar seus membros;

VIII - discutir e votar textos de documentos e de propostas que lhe forem encaminhadas pelas câmaras técnicas;

IX - estimular a captação de recursos para programas nesta APA, através de doações, estabelecimento de convênios, dotações do Poder público e demais formas de captação de recursos nacionais e internacionais;

$X$ - priorizar e sugerir a forma e os procedimentos para a aplicação dos recursos provenientes das multas aplicadas na APA; de acordo com o disposto pelo regulamento do Fundo Municipal do Meio Ambiente;

XI - promover a articulação entre órgãos governamentais, sociedade civil e organizações não governamentais, ensejando esforços para o entrosamento entre essas entidades, visando atender aos objetivos desta lei;

\footnotetext{
${ }^{86}$ O Regimento Interno foi apresentado no capítulo 1.7.
} 
XII - fazer permanentes gestões junto aos Municípios contíguos a esta APA, de forma a contribuir para que suas ações integrem os objetivos a que refere esta Portaria;

XIII - gerenciar a alocação de recursos humanos provenientes de aplicação de penas criminais alternativas, dentro da área protegida;

XIV - gerenciar o cumprimento das medidas provenientes da substituição de penalidades pecuniárias, dentro da área protegida;

$\mathrm{XV}$ - avaliar e opinar sobre o cumprimento dos programas, planos, projetos e ações pertinentes a esta APA;

$\mathrm{XVI}$ - apresentar Relatório de Qualidade Ambiental desta APA, com base no zoneamento ambiental, a cada cinco anos;

XVII - rever o Plano de Manejo Ambiental a cada cinco anos;

XVIII - publicitar informativo sobre realizações do conselho, pelo menos a cada dois anos.

Existe direcionamento legislativo no conselho gestor da APA Bororé-Colônia, os instrumentos incluem exigências para que os cidadãos participem da tomada de decisão e estão elaborados na forma de proposição escritas. Estruturalmente, os instrumentos legais existem e são concisos, porém, o que se observa na prática é que eles funcionam em uma capacidade muito baixa perto de todo seu potencial.

Além das limitações já expostas, observa-se que o poder público que atua na APA Bororé-Colônia não tem garantido as condições necessárias para a supressão da cobertura vegetal; tão pouco as condições necessárias para a disposição adequada de resíduos sólidos, para o despejo de efluentes. O zoneamento geoambiental não foi instituído e os recursos financeiros previstos para a gestão da APABC nunca foram provisionados. Por mais que seja obrigatório um programa de educação ambiental permanente na APA Bororé-Colônia este nunca existiu, conforme mencionado anteriormente.

O conselho gestor da APA Bororé-Colônia enfrenta grandes desafios para cumprir com suas atribuições. O zoneamento ambiental e o Plano de Manejo da APABC não foram realizados por ausência de recursos financeiros e por outras dificuldades enfrentadas pelo caminho, que estão mais bem descritas dois tópicos adiante. O colegiado não tem conseguido estimular a captação de recursos para programas na APABC e tão pouco tem influenciado na aplicação dos recursos provenientes da aplicação de multas na unidade de conservação.

Embora seja muito relevante e fundamental para a institucionalização das políticas públicas, apenas a existência do direcionamento legislativo não garante que o texto seja 
aplicado na prática. Há um longo caminho a percorrer para que tanto a APA Bororé-Colônia quanto seu conselho alcancem suas atribuições legais previstas.

\section{Existência de um sistema nacional de unidades de conservação planejado}

Para os autores Graham, Amos e Plumptre (2003), a existência de um sistema de unidades de conservação planejado inclui o estabelecimento de objetivos claros e quantificáveis para a gestão das diferentes categorias de UCs, a definição de prioridades para a fase de planejamento, a inclusão de requisitos em sua implantação para a participação dos cidadãos, em especial a população local e os povos indígenas.

Conforme foi colocado no capítulo que trata do Sistema Nacional de Unidades de Conservação (SNUC), instituído pela Lei no 9.985/2000, houve um ordenamento das UCs no Brasil estabelecendo objetivos de gestão para diferentes categorias de unidades de conservação, definindo algumas prioridades para a fase de planejamento, incluindo e prevendo a participação dos cidadãos na gestão. Porém, ainda existem muitos entraves para seu avanço; a inexistência de planos de trabalho, a ausência de instrumentos de avaliação e monitoramento, a alta vulnerabilidade, a presença constante de ameaças aos objetivos de gestão das UCs, a ausência de recursos para o manejo das áreas foram alguns dos pontos críticos avaliados pelo método RAPPAM ${ }^{87}$ (WWF, 2004).

Como apontado, existem diversas UCs dentro e no entorno da APA Bororé-Colônia, que compõem um mosaico não institucionalizado. É contraditória uma gestão desconectada de todas essas áreas, afinal o território está amplamente conectado pelos processos naturais e humanos. A gestão municipal dessas unidades de conservação é realizada pelo Departamento de Parques e Áreas Verdes (DEPAVE) no 8 da Secretaria do Verde e do Meio Ambiente, cujos funcionários ocupam um escritório no bairro do Paraíso, em São Paulo, distante cerca de vinte e cinco quilômetros das áreas que gerenciam. $\mathrm{O}$ fato de ocuparem $\mathrm{O}$ mesmo espaço físico para trabalhar acaba por facilitar a realização de ações e planejamentos

87 O método RAPPAM para avaliação rápida e priorização de manejo de unidades de conservação foi desenvolvido com o intuito de oferecer ferramentas para o desenvolvimento de políticas que fomentem a proteção das florestas e o desenvolvimento de uma rede viável de unidades de conservação. Até 2004 o método havia sido aplicado em vinte e três países, incluindo o Brasil, e seu foco foi na análise integrada do conjunto de áreas, ou seja, do sistema de unidades de conservação. O RAPPAM foi aplicado por uma parceria entre a organização não governamental Word Wild Fund for Nature (WWF) Brasil, o Instituto Florestal e a Fundação Florestal em unidades de conservação no Estado de São Paulo (WWF, 2004). 
conjuntos no âmbito municipal, e, conforme apresentado nas últimas reuniões do conselho gestor da APABC, está havendo um esforço de integração entre as APA municipais e os Parques Naturais Municipais. Porém, é importante que essa postura seja institucionalizada e não algo casual, até para se aproveitar a janela de oportunidade que a atual configuração de gestão por parte da SVMA tem permitido.

A gestão do Parque Estadual da Serra do Mar é realizada pela Fundação Florestal (FF), da Secretaria do Meio Ambiente do Estado de São Paulo, a partir de gestores que ocupam escritórios em cada núcleo da unidade de conservação. Embora complexa, a gestão mais compartilhada entre a SMA e a SVMA, conforme citado anteriormente, é importante para a consolidação de projetos mais amplos que contribuam no estabelecimento de uma visão estratégica para lidar com as ameaças e com as oportunidades, bem como permitam a consolidação da governança local.

\section{Existência de plano de gestão individualizado}

Graham, Amos e Plumptre (2003) destacam a relevância de se contar com um plano de gestão individualizado para a unidade de conservação que reflita a participação dos cidadãos, aprovado formalmente, com objetivos claros que atendam a legislação vigente, com metas e resultados mensuráveis para serem atingidos, com um cronograma para orientar o trabalho, e que seja revisado com frequência.

A legislação prevê tudo isso com a elaboração do Plano de Manejo da APA BororéColônia, porém esse documento ainda não foi concebido. A Universidade de São Paulo (USP) deveria ter feito o Plano de Manejo da APABC devido a obrigações oriundas de um Termo de Compensação Ambiental (TCA) com a Secretaria do Verde e do Meio Ambiente, porém o prazo espirou e o serviço não foi entregue.

De modo emergencial, nessa última gestão (2013-2015) foi elaborado pela Câmara Técnica de Planejamento e Gestão um Plano de Gestão. Este documento foi desenvolvido entre outubro de 2013 e julho de 2014 e aprovado em plenária em 29/07/2014, intui estabelecer os objetivos, diretrizes e ações a serem executados pela gestão no período de setembro de 2013 a setembro de 2015 (PREFEITURA MUNICIPAL DE SÃO PAULO, 2014c). Observou-se, entretanto, que o Plano de Gestão não é amplamente consultado pelos 
conselheiros, sendo mais um documento acessório ao gestor. Para avaliar a gestão do ano de 2014, em janeiro de 2015, durante reunião ordinária, foi apresentado um Relatório Executivo pelo gestor da APABC. De modo semelhante ao Plano de Gestão, o Relatório Executivo ${ }^{88}$ foi elaborado pela Câmara Técnica de Planejamento e Gestão.

É imprescindível que na elaboração do Plano de Manejo da APA Bororé-Colônia seja promovida uma participação qualitativa da comunidade local, previsto um programa de educação ambiental permanente para o conselho gestor da APABC, bem como considerada a existência das demais unidades de conservação e a relevância de se pensar em estratégias conjuntas para o enfrentamento dos desafios, para lidar com as oportunidades e para ampliar a governança das comunidades locais.

\section{Demonstração de liderança efetiva}

A existência de um gestor que ofereça uma visão inovadora e consistente ao desenvolvimento em longo prazo da unidade de conservação, que mobilize apoio para esta visão, que reúna recursos necessários à implantação da UC é fator muito importante na construção do direcionamento da área protegida (GRAHAM; AMOS; PLUMPTRE, 2003). O gestor é quem personifica o poder público que responde por aquele espaço, além de ser o "burocrata de rua" (MEYER, 2010), aquele servidor público que está em contato direto com o cidadão comum. Porém, a existência de um técnico com um perfil adequado para a execução de todas essas características não é suficiente. É imprescindível que o órgão onde este gestor atue, ou seja, o órgão gestor da UC, forneça condições para o desempenho deste profissional.

Sem dúvida a APA Bororé-Colônia possui ao longo de sua recente história gestores muito compromissados que conseguiram mobilizar olhares e apoio, fato muito feliz. Porém, conforme citado no capítulo que trata das políticas públicas que permeiam o conselho, estes funcionários estão à mercê de decisões top-down da Secretaria do Verde e do Meio Ambiente que podem ser influenciadas por fatores que não são técnicos, muito pelo contrário. O cargo de gestor de UC no nível municipal é muito desvalorizado, a remuneração

${ }^{88} \mathrm{O}$ documento ainda não se encontra disponível para acesso, pois até meados de junho não havia sido concluído. 
é baixa e não há plano de carreira, o cargo é preenchido por técnicos indicados, sendo passível a alocação de "cabos eleitorais".

As limitações da APABC nesse sentido estão para além do gestor da UC, e muito mais arraigadas na SVMA e, pode-se dizer, também, nas demais pastas do governo. Pelas características do território da APA Bororé-Colônia, as pastas do poder público representadas no conselho gestor têm amplas obrigações e competências de atuações no território, que se fossem efetuadas com qualidade contribuiriam de forma efetiva para a consolidação da unidade de conservação. A existência de uma atuação conjunta, intersetorial entre as pastas da Secretaria do Verde e do Meio Ambiente e entre esta pasta e as demais existentes no poder público é muito importante para a materialização dos objetivos de gestão da APABC. Adiante, no princípio do desempenho, no critério que trata da coordenação, essa questão será aprofundada.

\subsection{Desempenho}

Quando se fala em desempenho, para os autores Graham, Amos e Plumptre (2003) estamos tratando de eficácia, de eficiência e de coordenação interinstitucional. Eficácia se refere à capacidade em se atingir os objetivos de gestão da unidade de conservação, relacionados principalmente à conservação, à qualidade de vida das populações locais, comunidades tradicionais e povos indígenas, à promoção da pesquisa científica e às oportunidades de uso público e educação ambiental (GRAHAM; AMOS; PLUMPTRE, 2003).

Para os autores, a avaliação da eficácia passa pela compreensão da articulação entre os objetivos e do entendimento de como objetivos conflitantes são equilibrados na prática. Nessa avaliação acaba-se levantando uma questão fundamental que consiste em considerar se a instituição ou órgão gestor tem a capacidade necessária para cumprir sua missão ou objetivos (GRAHAM; AMOS; PLUMPTRE, 2003).

A eficiência estabelece uma relação direta com o desempenho na medida em que o uso dos recursos financeiros de maneira econômica na gestão de unidades de conservação tem sido um tema recorrente de estudos, demonstrando a sua relevância (GRAHAM; AMOS; PLUMPTRE, 2003). Já a coordenação interinstitucional se relaciona com a capacidade de aprender e ajustar com a experiência e a habilidade de conhecer e manejar os riscos 
(GRAHAM; AMOS; PLUMPTRE, 2003). Nas próximas linhas buscar-se-á fazer a análise dos critérios que sustentam este princípio aplicado ao conselho gestor da APA Bororé-Colônia.

\section{Eficiência em atingir objetivos}

Boa parte das unidades de conservação brasileiras não é eficiente em atingir seus objetivos de gestão (WWF, 2004; IBAMA, 2007). Ainda estamos em estágios preliminares de desenvolvimento e o mesmo ocorre com os conselhos gestores das UCs, eles ainda enfrentam muitos desafios para cumprirem seu objetivo de efetivar a participação da sociedade na gestão ambiental pública (ABERS; KECK, 2008; COZZOLINO, 2005; IRVING et. all., 2006; LOUREIRO; AZAZIEL; FRANCA, 2003; LOUREIRO; CUNHA, 2008). As APA objetivam adequar às atividades humanas às características ambientais da área, tendo em vista a conservação da diversidade de ambientes, espécies e processos naturais, além da melhoria da qualidade de vida da população que habita a UC. Atingir esses objetivos implica em um complexo sistema de gestão ambiental, conforme vem sendo esclarecido ao longo deste estudo.

No conselho gestor da APA Bororé-Colônia não é diferente, existem grandes desafios para alcançar a eficiência. A elaboração do Plano de Manejo e a captação de recursos financeiros, por exemplo, são alguns dos seus objetivos que não parecem ter condições de serem consolidados em um horizonte próximo. Outras dificuldades dizem respeito aos empecilhos de legitimidade que transcendem as relações entre representantes e representados, bem como a presença dos mesmos representantes do poder público nos diversos fóruns regionais; que atuam com baixa propriedade nesses colegiados, desqualificando o potencial do conselho gestor da APABC e demais fóruns como espaços educativos, espaços capazes de encaminharem soluções aos conflitos e espaços onde é garantida a igualdade de direitos entre os cidadãos.

Embora enfrente grandes empecilhos, o conselho gestor da APA Bororé-Colônia reveste-se de importância como espaço de nexo entre a sociedade civil e o poder público com amplas responsabilidades de atuação na APABC. O colegiado também fomenta a promoção da consciência e do comprometimento com a causa da unidade de conservação. A APA Bororé-Colônia só existe quando as pessoas que habitam aquele território reconhecem a sua existência. As pessoas e a relação que elas estabelecem com aquele 
território são a APABC, os conflitos sociais são a essência das contradições que refletem a existência de diferentes atores, alguns com interesses públicos e outros atores de mercado, com interesses privados.

\section{Capacidade}

Esse critério diz respeito a capacidade de se encarregar das funções requisitadas, especialmente as ligadas a sua gestão (por exemplo: conservação, ciência, oportunidades de visitação, necessidades locais), a sua autoridade (por exemplo: regulação e planejamento, controle da aplicação de recursos, geração de rendas, acordos) e a sua capacidade técnica (GRAHAM; AMOS; PLUMPTRE, 2003).

A Secretaria do Verde e do Meio Ambiente e as demais instituições governamentais que atuam no território da APA Bororé Colônia não têm demonstrado estarem dotadas de capacidade em se encarregar das funções requisitadas ligadas as suas gestões, as suas autoridades e as suas capacidades técnicas. A conservação dos remanescentes florestais e dos mananciais está comprometida; o Estado, responsável pela proteção dos mananciais, e demais órgãos do poder público com responsabilidades sobre o território não tem cumprido qualitativamente com suas atribuições. As denúncias encaminhadas pelo conselho gestor da APA Bororé Colônia não refletem na supressão do vetor de pressão, a expansão de loteamentos e a construção ilegal e indiscriminada de residências, além de outras ameaças, são recorrentes no território.

As oportunidades de uso público e educação ambiental em ambientes naturais estão em boa parte a cargo da iniciativa privada, em propriedades particulares. As áreas públicas com potencial para essas atividades, incluídas principalmente nos Parques Naturais Municipais Itaim, Bororé, Jaceguava e Varginha, estão fechadas ao acesso público por limitações por parte da Secretaria do Verde e do Meio Ambiente de recursos financeiros e humanos imprescindíveis à abertura das unidades de conservação, bem como pela ausência dos Planos de Manejo. A atuação da SVMA na promoção da educação ambiental tem sido realizada pelos núcleos verdes ${ }^{89}$, que estabelecem relações pontuais com as UCs. Neste sentido, o núcleo Sul 3 atua em Parelheiros e em Capela do Socorro, e desenvolve atividades

\footnotetext{
89 Levando em consideração as características e problemas ambientais que variam de uma localidade para outra e como estratégia a SVMA estabeleceu como uma de suas políticas a descentralização e desconcentração das atividades a partir da implementação nos núcleos verdes.
} 
junto à população, acompanham os projetos de educação ambiental contemplados pelo FEMA e promove uma agenda de eventos para a população local.

As necessidades das populações locais, aquelas com o referencial mais ligado ao território rural, têm enfrentado grandes obstáculos para serem atendidas. Embora estejam presentes na agenda do conselho gestor da APA Bororé-Colônia não encontram encaminhamentos efetivos. Já foi colocada a incapacidade do poder público em representar os interesses dessas minorias e em atuar no território de modo a atender as demandas desses cidadãos. Como exemplo pode-se citar a manutenção das estradas de terra que existem na $A P A B C$, um assunto que está sempre presente, desde os primórdios do conselho (GONÇALVES, 2010) até os dias atuais, mas que não se resolve. Importante ressaltar, mais uma vez, que a responsabilidade da manutenção das estradas de terra cabe a outras pastas do poder público, em especial as Subprefeituras de Capela do Socorro e Parelheiros, e não a Secretaria do Verde e do Meio Ambiente.

A possibilidade de desenvolver pesquisas científicas também pode ser conduzida de uma melhor forma; não há uma prioridade de assuntos que demandam pesquisa, tampouco existem convênios com as instituições de ensino e pesquisa visando o atendimento de demandas específicas da APA Bororé-Colônia ou do conselho. O conselho gestor da APABC pode elaborar uma agenda com temas prioritários de pesquisa.

Quanto a sua autoridade, o conselho não atua no controle e na aplicação de recursos, pois atualmente a APA Bororé-Colônia não possui orçamento, não tem capacidade para gerar rendas e a Secretaria do Verde e do Meio Ambiente não tem assumido sua obrigação de fornecer os recursos necessários para sua gestão. Diante disso, sua capacidade de regulação e planejamento fica muito limitada, ainda mais considerando que o quadro de recursos humanos da APA Bororé-Colônia se restringe a um gestor. Importante mencionar que não há o reconhecimento por parte do colegiado da necessidade da APABC contar com um orçamento. Recursos financeiros podem viabilizar contratações para executar as demandas do conselho que são suas atribuições e que não são concorrentes com a atuação dos demais órgãos, instituições e instâncias do poder público, sendo o conselho e a SVMA os gestores dos contratos. Na função de gestor e não de executor é possível ampliar suas atuações na unidade de conservação. 


\section{Coordenação}

Coordenação diz respeito à capacidade e habilidade em coordenar esforços com os principais atores envolvidos, sejam eles governamentais ou não (GRAHAM; AMOS; PLUMPTRE, 2003). O território da APA Bororé-Colônia se estende por terras públicas e privadas, então tudo que é deliberado no conselho depende de outros órgãos, às vezes de nível estadual ou federal, ou outros departamentos da Secretaria do Verde e do Meio Ambiente, que não seja o departamento gestor da unidade de conservação, ou depende ainda da sociedade civil para ser executado. Em geral, boa parte do que depende do poder público não avança, é deliberado e não se concretiza, ou, por vezes, pode ser fruto de ações descoordenadas entre os vários órgãos ou departamentos de instituições que atuam na área (GONÇALVES, 2010).

Diante do que vem sendo exposto, percebemos que o conselho gestor não possui muita habilidade e capacidade de coordenar esforços com os principais atores envolvidos, sejam eles governamentais ou não. A dificuldade parece ser maior quando se trata dos atores governamentais. Estes parecem que ainda não reconheceram a APA Bororé-Colônia e não cumprem com seus papéis no fórum, estão sempre se esquivando e apresentando uma postura defensiva ao invés de conseguir fazer a ponte entre a instituição que representam e aquele espaço. A questão dos loteamentos e das invasões, por exemplo, é assunto que demanda atuação do poder público no que tange a fiscalização, a habitação, ao saneamento, pautas que não competem a Secretaria do Verde e do Meio Ambiente, e sim a outras pastas do município e algumas vezes também do estado. A maioria destas instituições encontra-se representadas no conselho ${ }^{90}$, embora muitas vezes não se manifestem, ou o façam de maneira desconversada quando os conflitos que lhes dizem respeito emergem. A articulação entre as organizações, instituições ou instâncias de governo é muito incipiente ou ineficiente.

Sem dúvida o conselho gestor da APA Bororé-Colônia precisa debruçar mais energias nessa pauta, e mais do que isso, a Secretaria do Verde e do Meio Ambiente tem de assumir

90 Caso, por exemplo, da Secretaria Municipal de Habitação, da Secretaria Municipal de Planejamento, da Subprefeitura de Parelheiros, da Subprefeitura de Capela do Socorro, da Polícia Milita Ambiental. 
essa demanda e fazer a articulação necessária. A falta de reconhecimento da existência da APABC, a ausência de legitimidade da SVMA perante outros atores envolvidos e a insuficiência de articulação da SVMA com esses atores são grandes desafio para a gestão da unidade de conservação e do seu conselho.

Em uma análise feita pelo Governo do Estado de São Paulo sobre as causas secundárias que levam a "Deficiência na gestão de unidades de conservação" a especificidade de domínio da área das APA, que se estendem por terras públicas e privadas, e a sobreposição de instrumentos de ordenamento territorial foram apontadas como fatores que levam à governabilidade parcial e impactam negativamente na gestão das APA marinhas e terrestres (SECRETARIA DO MEIO AMBIENTE DO ESTADO DE SÃO PAULO, 2013). A governabilidade parcial é um fato na natureza das APA, e isso não é considerado um aspecto negativo neste estudo. O que deriva desse fato é que é fundamental e de grande relevância para a gestão deste tipo de unidade de conservação uma articulação entre as diversas pastas do poder público. Neste sentido, se levanta o questionamento, por hora sem resposta, se há interesse político por parte dos atores governamentais em coordenar esforços para efetivar a implantação da APABC?

É necessário que haja uma sensibilização quanto à questão da representatividade dos conselheiros do poder público. Em uma instância como o conselho gestor da APA BororéColônia é fundamental que estes conselheiros consigam cumprir com o papel para o qual foram designados, fazendo a real interlocução entre aquele fórum e a instituição pública que representam. Afinal, as pastas representadas possuem atuação concreta no território e são agentes fundamentais na consolidação daquilo que é deliberado, devendo prestar contas de sua atuação e omissão quando for o caso. Além do que, na garantia da igualdade, na representação daqueles que estão sendo oprimidos e marginalizados, cabe aos representantes do governo garantir os direitos de todos os cidadãos. O poder público deve se preocupar com a sensibilização dos cidadãos assim como dos gestores públicos, ademais pode fornecer capacitação para ampliar as condições de igualdade entre os cidadãos na gestão ambiental pública; missões que podem ter a contribuição do programa de educação ambiental permanente do conselho gestor da APABC, previsto em seu regimento interno e que ainda não foi implantado, para ser cumprida. 


\section{Informações ao público sobre o desempenho}

Prover informações suficientes sobre o desempenho para facilitar a cooperação governamental e do público em geral é fundamental para a "boa"' governança das áreas protegidas (GRAHAM; AMOS; PLUMPTRE, 2003). O conselho gestor da APA Bororé-Colônia precisa empenhar grandes esforços para cumprir com esse critério. A sociedade inserida na APA Bororé-Colônia está muito longe de acompanhar sua gestão, os cidadãos ainda não tomaram conhecimento de sua existência, ou quando sabem que a $A P A B C$ existe não compreendem quais são seus objetivos, como se dá sua gestão. Não existe um canal de comunicação entre o conselho e a comunidade da APABC, ou entre o conselho e os órgãos governamentais. Mesmo para os conselheiros é difícil acompanhar a gestão.

O conselho tem feito o uso do recurso tecnológico; existe um grupo em uma plataforma gratuita na internet no qual os conselheiros e demais interessados no conselho gestor da APA Bororé-Colônia se inscrevem a partir do cadastramento de um e-mail. A administração desse grupo é realizada pelo gestor da APABC e todos os integrantes podem compartilhar mensagens e arquivos. Neste espaço virtual deveriam estar disponíveis todos os documentos de interesse do conselho para consulta dos integrantes do grupo; tais como as atas das reuniões ordinárias, pareceres técnicos, ofícios, planos, relatórios. Porém, este grupo virtual não tem sido alimentado e apenas alguns documentos se encontram disponíveis nesta plataforma. Tal fato acontece porque o gestor da APABC encontra-se sobrecarregado e não consegue atualizar o espaço virtual. Por outro lado os conselheiros parecem não estar incomodados, não reclamam pela atualização e tampouco se oferecem para compartilhar a tarefa, um indicativo de desinteresse.

A ideia de usar o recurso tecnológico tem sido cada vez mais frequente na busca pela divulgação ao público de dados governamentais. Porém, há de atentar para suas limitações. As lideranças comunitárias de mais idade, que no caso em estudo representam as associações de moradores locais, não têm afinidade com este tipo de ferramenta. Por mais que possuam acesso, fazem um uso muito limitado do recurso tecnológico. Como conselheiros e como figuras importantes em suas comunidades é fundamental que a 
ferramenta de divulgação adotada pelo conselho chegue nesse tipo de cidadão e também no público final que ele representa.

Como sugestão, o conselho poderia adotar estratégias de comunicação comunitária, as quais podem ser criadas a partir de iniciativas em parceria com a comunidade e veiculada em locais de acesso da população local, como as escolas, os comércios locais, os postos de saúde. Para tanto, pode ser adotado um projeto processual, que contemple oficinas para conselheiros, lideranças locais e para os professores e dirigentes da rede de ensino. Além de permitir que esses cidadãos tomem contato com técnicas para a elaboração de fanzines, informativos, cartazes, fotografia, e outras, o pano de fundo desse processo deve ser pautado por uma abordagem que dê profundidade crítica a essa comunicação, que ressalte o papel dessas pessoas em promover o acesso de informações que permitam a sociedade acompanhar o desempenho da APA Bororé-Colônia e facilitem a cooperação dos cidadãos e do governo na gestão da unidade de conservação.

A comunicação pautada por uma estratégia que fomente o diálogo, e orientada por uma reflexão que busque a inserção da comunidade como sujeitos ativos, fomentando sua participação na gestão ambiental pública, pode ser uma boa estratégia para o conselho gestor da APA Bororé-Colônia. Existe uma preocupação por parte dos conselheiros da sociedade civil dessa comunicação ser pautada pela intencionalidade da SVMA, mascarando a realidade. Cabe aos conselheiros, de modo organizado, por meio da Câmara Técnica, gerir essa comunicação fazendo as negociações que sempre são necessárias com o poder público. No entanto, fora do conselho, a autonomia frente ao conteúdo da informação que é replicada cabe apenas à entidade multiplicadora. Neste sentido, a manifestação em outras mídias e a existência de mídias independentes, conforme exposto no capítulo que trata da legitimidade e voz do conselho, são fatores importantes para ampliar as informações para o público. O princípio da prestação de contas, adiante, aprofunda essa temática da transparência e do acesso à informação.

Outro fato constatado que amplia a distância entre o órgão gestor e a sociedade é a inexistência de uma sede institucional e física da Secretaria do Verde e do Meio Ambiente no território da APA Bororé-Colônia, dificultando o acesso ao gestor da unidade de conservação e ao poder público responsável pela área protegida. O gestor procura fazer vistorias e incursões no território para estabelecer contato com mais moradores, porém são ações 
pontuais, não existe uma conexão diária da SVMA com a comunidade que habita a unidade de conservação.

\section{Responsividade}

Responsividade, para os atores Graham, Amos e Plumptre (2003), tem relação direta com a capacidade em lidar com críticas e queixas do público. Neste sentido, a responsividade do conselho gestor da APA Bororé-Colônia é muito limitada. O fórum permite o estabelecimento do diálogo sobre demandas e queixas das comunidades locais, a exemplo da manutenção das estradas de terra, da água contaminada nos poços da Ilha do Bororé, das denuncias sobre a disposição incorreta de resíduos sólidos, entre outros, que são assuntos recorrentes. Mas os representantes do poder público, salvo raras exceções, estão sempre na retaguarda. As subprefeituras de Capela do Socorro e de Parelheiros têm grandes responsabilidades sobre o território da $A P A B C$ e não são atuantes no conselho gestor, não qualificam a discussão do fórum, não se posicionam, não conseguem dar respostas satisfatórias para a sociedade civil.

Os conselheiros ficam desmotivados com essa baixa responsividade, principalmente aqueles ligados a sociedade civil, pois para estes o termômetro da participação tem muita relação com a concretização no território do que é deliberado naquele fórum. Lidar com o baixo desempenho é desmotivador e essas pessoas têm dificuldades em construir argumentos ou enxergar respostas às críticas que lhes são feitas enquanto colegiado. Ainda assim, a maior parcela dos conselheiros da sociedade civil permanece frequentando o conselho gestor da APA Bororé-Colônia, em alguns casos até por mais de uma gestão.

\section{Monitoramento e avaliação}

Esse critério diz respeito à capacidade em se comprometer com monitoramento e avaliações abrangentes e regulares, incluindo monitoramento de longo prazo de indicadores chave culturais e ecológicos, e responder aos achados (GRAHAM; AMOS; PLUMPTRE, 2003). A capacidade do conselho gestor da APA Bororé-Colônia em se comprometer com monitoramento e avaliação abrangentes e regulares é baixa, muito instável e está condicionada ao perfil do gestor da unidade de conservação que preside o conselho, não 
está institucionalizada na Secretaria do Verde e do Meio Ambiente ou no colegiado. Nesta última gestão (2013-2015) houve o empenho do gestor que mobilizou a Câmara Técnica de Planejamento e Gestão para elaborar um "Relatório Executivo Anual” ao final de 2014.

O objetivo deste relatório foi apresentar e divulgar as ações da APA Bororé-Colônia para os conselheiros e o documentou contemplou a apresentação do status das ações, projetos e eventos desenvolvidos durante o ano na APABC, tanto por parte do conselho quanto por conta das demais instituições que atuam no território da unidade de conservação. O documento foi apresentado para os conselheiros na primeira reunião do ano de 2015, no mês de janeiro.

O relatório apontou que, durante sete meses de gestão, ao longo do ano de 2014, foram propostos cento e dezessete ações e projetos. Destes, $72 \%$ foram iniciados, $59 \%$ estão em andamento, $37 \%$ tiveram seu prazo esgotado e dezesseis $(13,5 \%)$ foram concluídos. Os projetos e ações foram enquadrados nos quatorze programas de ação da APA BororéColônia, listados na tabela abaixo, sendo que a partir da análise do status dos projetos e ações se sintetizou o status dos programas. 0 resultado obtido apresenta-se na tabela 1, a seguir.

Tabela 1: Status dos projetos concluídos nos programas de ação da APA Bororé-Colônia.

\begin{tabular}{l|c}
\hline \multicolumn{1}{c|}{ Programas de Ação } & $\begin{array}{c}\text { Projetos concluídos } \\
\text { em relação ao } \\
\text { Programa de Ação }\end{array}$ \\
\hline Saneamento ambiental e infra-estrutura & $0 \%$ \\
\hline Pesquisa científica & $20 \%$ \\
\hline Uso do solo & $20 \%$ \\
\hline Empreendimentos & $18 \%$ \\
\hline Patrimônio histórico & $0 \%$ \\
\hline Fiscalização e monitoramento & $0 \%$ \\
\hline Atividades econômicas sustentáveis & $33,50 \%$ \\
\hline Manifestações culturais e esportivas & $0 \%$ \\
\hline Turismo sustentável & $0 \%$ \\
\hline Agricultura & $20 \%$ \\
\hline Educação Ambiental & $22 \%$ \\
\hline Gestão dos Parques Naturais Municipais & $0 \%$ \\
\hline Comunicação & $21,50 \%$ \\
\hline Planejamento & $22 \%$ \\
\hline
\end{tabular}

Fonte: PREFEITURA MUNICIPAL DE SÃO PAULO , 2014h. Organizado pela autora. 
Há fragilidade no que tange ao monitoramento e avaliação do conselho gestor da APA Bororé-Colônia, mas está claro que existe preocupação com essa pauta. É importante considerar que Gonçalves (2014) propôs um sistema de monitoramento para APA, com indicadores construídos de forma coletiva junto ao conselho gestor da APA Capivari-Monos, que foi aplicado nesta APA. Segundo o autor, que na ocasião era gestor da APA BororéColônia, consiste em um trabalho pesado de ser planejado e executado e, para ele, a APABC tem de evoluir em aspectos muito estruturais da gestão pública antes de se pensar em indicadores de avaliação e monitoramento, pois os resultados já estão explícitos.

\section{Gestão adaptativa}

A gestão adaptativa consiste na habilidade em exercer uma política de aprendizagem e de ajustes das ações de gerenciamento a partir da experiência operacional (GRAHAM; AMOS; PLUMPTRE, 2003). Trata-se de um critério complexo e longínquo, que deve ser observado como um processo, fato que o curto período de análise deste estudo não contempla, portanto, a análise realizada é limitada.

Acredita-se que no conselho gestor da APA Bororé-Colônia a gestão adaptativa acaba por se dar de maneira empírica, mais pautada na experiência e na observação. Sem dúvida há um esforço por parte do gestor da unidade de conservação em encontrar uma direção, em ajustar as ações e buscar o apoio dos conselheiros neste sentido, em uma situação de aprendizado conjunto. Porém, todos os obstáculos e dificuldades que interferem na qualidade da participação e da representatividade que vem sendo apresentados ao longo desse texto, bem como a baixa qualidade da participação do poder público no colegiado, interferem na capacidade de gestão adaptativa do conselho gestor da APA Bororé-Colônia, comprometem o desempenho do fórum e esvaecem a possibilidade de serem criados e adotados novos caminhos.

\section{Gerenciamento de riscos}

Identificar riscos que interferem na "boa" governança é extremamente complexo. De certo existem ameaças que interferem no conselho e que são percebidas de modo empírico por parte dos conselheiros. Porém, os riscos não foram identificados e gerenciados. A 
habilidade de gerenciar riscos sem dúvida é importante, mas é um passo além das demais capacidades já citadas. Ainda que este processo não seja cartesiano, com uma etapa iniciando ao término da outra, acredita-se que o conselho primeiro precisa pelo menos iniciar seu percurso e completar alguns passos pelos critérios anteriores contemplados no princípio do desempenho para depois conseguir avançar no gerenciamento de riscos.

Essa discussão, na verdade, tem de amadurecer no âmbito dos conselhos gestores das unidades de conservação. Da mesma forma que os estudos iniciais sobre a eficiência das unidades de conservação em atingir seus objetivos de manejo estavam mais pautados pelas lentes da preservação ambiental e aos poucos têm incorporado à dimensão social, os estudos sobre os riscos que afligem as unidades de conservação também atendem a mesma lógica. É interessante uma aproximação da Secretaria do Verde e do Meio Ambiente com a Secretaria de Meio Ambiente do Estado de São Paulo, e quiçá com outros órgãos gestores de UCs pelo Brasil, tendo em vista estudos conjuntos que analisem os riscos que interferem na governança dos conselhos gestores das unidades de conservação.

\subsection{Prestação de contas}

Para explicar a prestação de contas, os autores Graham, Amos e Plumptre (2003) recorrem ao autor Andreas Schedler. Andreas (1999 apud GRAHAM; AMOS; PLUMPTRE, 2003) coloca que o poder e a necessidade de controlá-lo irão definir a barganha que ocorre entre os que governam e os que são governados; os cidadãos demandam prestação de contas em troca dos amplos poderes que concedem ao poder público, eles esperam que o governo explique e justifique publicamente como usa seu poder e tome medidas corretivas quando for necessário.

Na busca pela melhoria da governança, a redução da corrupção tem sido uma das principais preocupações e um grande desafio para muitas nações (GRAHAM; AMOS; PLUMPTRE, 2003). O Banco Mundial (2000 apud GRAHAM; AMOS; PLUMPTRE, 2003) a descreve como um câncer e sua redução é uma das melhores contribuições que uma prestação de contas eficaz pode trazer.

No contexto das áreas protegidas, a prestação de contas vai além da dimensão local entre os líderes políticos e os cidadãos que habitam o local governado (GRAHAM; AMOS; 
PLUMPTRE, 2003). Graham, Amos e Plumptre (2003) acreditam que a prestação de contas é um conceito mais amplo que deve se estender a toda comunidade mundial, às gerações futuras e também à natureza por ela mesma. Casar estes conceitos mais amplos de prestação de contas com os limites estreitos de responsabilidade política é um grande desafio para os gestores das unidades de conservação. Uma alternativa que os autores apontam seria a de incluir esses conceitos mais amplos na legislação que estabelece a área protegida e trata de sua gestão. Neste sentido, as convenções internacionais também têm grande potencial para prever mecanismos de prestação de contas específicos para governos (GRAHAM; AMOS; PLUMPTRE, 2003).

Para avaliar a qualidade dos dispositivos de prestação de contas em nível local é importante atentar para três aspectos (GRAHAM; AMOS; PLUMPLTRE, 2003). O primeiro diz respeito à existência de uma atribuição clara de responsabilidades, de modo que um indivíduo que tenha autoridade para agir seja responsável pelos resultados de sua atribuição (GRAHAM; AMOS; PLUMPLTRE, 2003). O segundo se refere à adequação da responsabilidade atribuída aos líderes políticos e funcionários não eleitos (GRAHAM; AMOS; PLUMPLTRE, 2003). Alguns argumentam que os líderes políticos não poderiam delegar algumas funções para organizações semi-independentes, tais como: políticas e programas de desenvolvimento; relações intergovernamentais; propostas regulatórias e que estabelecem padrões; programas com requisitos fortes para equidade e justiça (GRAHAM; AMOS; PLUMPLTRE, 2003). Essa concepção dialoga com a abordagem apresentada de que cabe ao poder público garantir a igualdade de direitos a todos os cidadãos, zelando pela inclusão das minorias nas políticas públicas, de modo que não se pode esperar que a sociedade civil o faça (ABERS; KECK, 2008). Então, políticas que são muito estruturais dentro dessa concepção devem ser encabeçadas pelo governo (GRAHAM; AMOS; PLUMPLTRE, 2003).

O terceiro aspecto se relaciona com os acordos de prestação de contas. A importância de contrapesos ao exercício do poder em governos democráticos é velha conhecida e reflete em elementos presentes nas Constituições de muitos países (GRAHAM; AMOS; PLUMPTRE, 2003). Apenas o voto não garante uma boa relação entre governantes e governados, existe outro conjunto de relações de prestação de contas. O poder do governo se restringe na medida em que cria e mantém instituições públicas independentes com poderes para supervisionar as suas ações, para demandar explicações sobre 
comportamentos impróprios ou ilegais e que tenham a capacidade de impor sanções quando for necessário (GRAHAM; AMOS; PLUMPLTRE, 2003). Graham, Amos e Plumptre (2003) consideram dois tipos de prestação de contas: responsabilização vertical e responsabilização horizontal. A primeira se destina aos cidadãos e pode ser promovida diretamente pelo poder público ou indiretamente por organizações da sociedade civil ou pela mídia, já a segunda trata das instituições públicas impostas pelo e para o governo visando sua prestação de contas, o que inclui as agências de auditorias, as comissões de direitos humanos, entre outras (GRAHAM; AMOS; PLUMPLTRE, 2003).

O papel desempenhado pela sociedade civil e pela mídia é muito importante na avaliação da qualidade da prestação de contas, pois seu potencial de articulação e mobilização da demanda por um governo responsável tem um impacto de reforço à atuação das instituições de prestação de contas em relação ao governo (GRAHAM; AMOS; PLUMPLTRE, 2003). Para a eficácia do papel que desempenham, entretanto, é fundamental que a sociedade civil e a mídia tenham acesso a informações sobre o desempenho e a gestão das áreas protegidas. Nessa relação que constrói a prestação de contas, a transparência é um elemento indispensável.

Embora toda a reflexão tenha se pautado em um contexto governamental, as questões que dizem respeito à prestação de contas também se aplicam para organizações não governamentais, para a sociedade civil organizada, desde que um representante ou grupo de representantes pretenda agir no interesse de um grupo mais amplo de membros ou cidadãos (GRAHAM; AMOS; PLUMPLTRE, 2003), situação dos representantes da sociedade civil presentes no conselho gestor da APA Bororé-Colônia. É claro que o modo como deve se dar essa prestação de contas é diferente do que ocorre em uma unidade de conservação, e tem relação direta com a representatividade discutida nas páginas anteriores.

\section{Clareza}

"Quem é responsável perante a quem e para quê?" é a pergunta que se busca responder quando se reflete sobre a clareza na atribuição de responsabilidades e autoridade para agir (GRAHAM; AMOS; PLUMPLTRE, 2003). Essa pergunta não é de fácil resposta. A APA 
Bororé-Colônia não possui um orçamento financeiro, então a prestação de contas não é sobre recursos financeiros e tem mais relação com a atuação do poder público na unidade de conservação, com o poder governamental. Essa atuação do poder público na área protegida é complexa, geralmente incompreendida pela maioria dos habitantes locais da APABC, bem como por parte dos conselheiros, em especial os da sociedade civil com menor escolaridade.

Além da incompreensão popular sobre o papel que cada ente do poder público representa, a APA Bororé-Colônia está inserida em uma área onde há uma complexa relação entre os dispositivos legais existentes (a exemplo da legislação que se aplica por conta da região estar inserida em um manancial, a lei de criação da APABC, o Plano Diretor do Município de São Paulo) dificultando o entendimento do cidadão que reside na unidade de conservação sobre a atribuição de responsabilidades e autoridade para agir. O conselho gestor da APA Bororé-Colônia acaba por ser um local onde essa questão se torna mais clara na medida em que o poder público, se posicionando de forma qualitativa, expõe suas responsabilidades e autoridades para agir, deixando claro sobre o que é o responsável perante a quem e para que. Mas esse fato não é uma constante, pois frequentemente os representantes do poder público não atuam de forma qualitativa no fórum, na maior parte estão em postura de retaguarda, como já fora mencionado.

Os estudos sobre conselhos gestores apontam corriqueiramente que os representantes do poder público que atuam nesses fóruns são servidores que não possuem efetivo poder dentro das instâncias que representam (COZZOLINO, 2005; IRVING et al., 2006). Esse fato é complexo, e denota que a questão da participação do poder público nesses colegiados não tem grande importância para as instituições. Acabamos por direcionar o olhar para os indivíduos, e é perceptível que há representantes do poder público que tem maior compreensão do papel que desempenham naquele fórum, tem maior capacidade de qualificar a participação da entidade que representam e procuram fazer dentro destas as articulações necessárias para o bom andamento das deliberações do conselho. Esses cidadãos são exceções, o que aponta para a demanda de um cenário que precisa ser modificado. O poder público precisa ser sensibilizado para a sua representação em colegiados como o conselho gestor da APA Bororé-Colônia; os tomadores de decisão 
precisam compreender a relevâncias desses fóruns e os representantes intitulados conselheiros precisam fazer a ponte e atuar de modo qualitativo no colegiado.

\section{Coerência e visão}

Deter coerência e visão tem relação com a integração dos conceitos tradicionais de prestação de contas públicas e aqueles mais amplos de prestação de contas à comunidade global, às futuras gerações e à natureza por ela mesma (GRAHAM; AMOS; PLUMPTRE, 2003). É um objetivo de longo prazo, que pode ser institucionalizado com o suporte do direcionamento internacional relativo às unidades de conservação (GRAHAM; AMOS; PLUMPTRE, 2003). Gonçalves (2015) também discute esse entendimento em seu estudo sobre sustentabilidade no conselho gestor da APA Capivari-Monos, ele considera um valor primário haver consenso sobre os objetivos últimos de uma unidade de conservação, uma visão coletiva para o futuro. Mas exige a aquisição de um elevado grau de consciência política, ambiental e social, e de participação; de consciência do papel de cada cidadão na sociedade e no conselho (GONÇALVES, 2015).

Esse critério acaba por ser muito subjetivo e um pouco romântico quando aborda a prestação de contas à natureza. Parece haver um sentimento de gratidão embutido nessa concepção, no sentido de que a "boa" governança das áreas protegidas poderia ser uma maneira de buscar restituir à natureza os impactos advindos da existência humana, como se fosse possível prestar contas para a natureza de nossa gestão.

De qualquer forma, trata-se de um critério complexo e que no momento ainda está longe de ser atingido pelo conselho gestor da APA Bororé-Colônia, pois ainda há muitos avanços em nível local para serem realizados. A legislação de criação da APA Bororé-Colônia não prevê esses mecanismos e embora a unidade de conservação seja integrante da Reserva da Biosfera do Cinturão Verde ainda não existem direcionamentos que se efetivem rumo a uma maior adesão a esse conceito mais amplo. Realmente é muito difícil para o gestor e para o conselho gestor da APA Bororé-Colônia conseguir casar os limites estreitos da responsabilidade política com esses conceitos mais amplos. 


\section{Papel dos líderes políticos}

Enxergar a adequação das responsabilidades atribuídas aos cargos eletivos, em contraposição ao papel de autoridades não eleitas e de órgãos de administração indireta (GRAHAM; AMOS; PLUMPTRE, 2003), reflete uma mentalidade muito avançada de governança, o que ainda é muito incipiente no conselho gestor da APA Bororé-Colônia. O território da APA Bororé-Colônia está sujeito à atuação de diversas esferas do poder público, desde a atuação municipal, perpassando pela estadual e chegando na federal. Enxergar e cobrar a adequação das responsabilidades atribuídas aos cargos eletivos em contraposição aos não eletivos é uma tarefa muito complexa para os cidadãos e para os conselheiros, principalmente para aqueles da sociedade civil. Neste sentido, o Plano de Gestão da APA Bororé-Colônia dedica-se em sua maior parte a apontar sua interface com os órgão públicos. Essa iniciativa é muito importante para elucidar a relação entre os programas, ações e projetos do conselho gestor da APABC com os órgãos públicos.

Com relação à corrupção, geralmente e historicamente ela vem atrelada a recursos financeiros, porém ela pode se manifestar de outras formas no governo. A história democrática do Brasil, nos níveis federal, estadual e municipal possui traços de corrupção em suas páginas. A população brasileira não tem tradição de acompanhar a aplicação de todo o montante de recursos públicos disponibilizados aos governantes, havendo muito ainda para se evoluir nesse aspecto. As unidades de conservação não são diferentes, no caso da APA Bororé-Colônia não existe recurso financeiro disponível para sua gestão. Embora seja previsto em lei a origem de seus recursos, a sociedade não conseguiu se mobilizar de modo efetivo para pressionar o poder público a assumir a unidade de conservação. Essa pauta também não está presente na agenda do conselho gestor da APABC, pois há conselheiros que não acreditam que a unidade de conservação necessite de um orçamento.

Realmente por se tratar de uma unidade de conservação de uso sustentável, formada por terras públicas e privadas, o gerenciamento da APA Bororé-Colônia é muito diferente de uma outra UC de proteção integral, a exemplo dos Parques Naturais Municipais, cujas terras são todas de propriedade do governo. Mas isso não significa que não seja necessário orçamento financeiro, além de recursos humanos em quantidade e com qualificação adequadas para se efetivar os objetivos da APABC. Apenas o gestor da UC não é suficiente, ainda mais sem recursos financeiros para fazer contratações que ele possa gerenciar com o 
apoio ou em parceria com o conselho. Todos os programas de ação da APABC poderiam se beneficiar da disponibilidade de recursos financeiros. A SVMA tem de assumir essa UC e custeá-la, mas sem a devida pressão por parte do conselho gestor da APABC esse objetivo parece estar mais longínquo.

\section{Instituições públicas de prestações de contas}

Esse critério prevê a existência de instituições de prestações de contas eficazes, o que inclui acesso à informação, capacidade de analisar e denunciar e capacidade de instaurar processos com mandatos abrangentes (GRAHAM; AMOS; PLUMPTRE, 2003). Uma diretriz prevista no programa de ação denominado planejamento do Plano de Gestão da APA Bororé-Colônia consiste em cobrar o poder público. De fato existe uma preocupação no conselho em ir além da responsabilização vertical e atingir a responsabilização horizontal (GRAHAM; AMOS; PLUMPTRE, 2003). Mas os assuntos referentes à APA Bororé-Colônia não ocupam grande espaço na agenda das instituições públicas impostas pelo e para o governo visando sua prestação de contas.

No ano de 2014 foram encaminhadas a partir do conselho gestor da APA BororéColônia cento e dezesseis denúncias de infrações ambientais à Guarda Civil Metropolitana, à Polícia Militar Ambiental, à Secretaria do Verde e do Meio Ambiente, à Subprefeitura de Capela do Socorro, à Subprefeitura de Parelheiros e à Companhia de Tecnologia e Saneamento Ambiental. É difícil mensurar quantas denúncias foram realmente averiguadas pelo órgão responsável. A realidade indica que os vetores de pressão no território da APA Bororé-Colônia permanecem constantes. Diante disso foram encaminhados pelo conselho sete ofícios cobrando manifestação perante o descaso para a fiscalização ambiental na APABC, nas demais unidades de conservação sobrepostas e no manancial, e solicitando um Plano Emergencial para as seguintes entidades: Secretaria de Meio Ambiente do Estado de São Paulo, Secretaria de Estado da Segurança Pública, Secretaria do Verde e do Meio Ambiente, Secretaria Municipal de Segurança Urbana, Subprefeitura de Capela do Socorro, Subprefeitura de Parelheiros e Secretaria do Governo Municipal.

As questões que estão por trás da ótica do programa de gestão denominado fiscalização e monitoramento, do Plano de Gestão da APA Bororé-Colônia, é um tema de 
extrema relevância e que na realidade possui interface com outras questões de ordem social e econômica mais profundas. Se os problemas que se manifestam nas denúncias encaminhadas forem realmente encarados pelo poder público na perspectiva de saná-los em sua origem será necessário articular esforços de várias pastas do governo. São problemas que estão muito além da capacidade de gestão da APABC e que precisam ser assumidos pelo poder público em todas as suas dimensões.

As instituições de prestação de contas que de certa forma estabelecem relação com o conselho gestor e com a APA Bororé-Colônia estão atuando de modo frágil. Difícil mensurar onde está o problema, se é no acesso à informação, na capacidade de analisar e denunciar, na capacidade de instaurar processos com mandatos abrangentes. Talvez esteja na ausência de uma atuação qualitativa do poder público e também na complexidade deste cenário, há questões muito sérias que incidem sobre o território da APABC. A ocupação humana irregular, por exemplo, é um desses conflitos sobre o qual incidem questões de diversas ordens; e a institucionalização da APABC enfrenta muitos obstáculos para contribuir de modo efetivo para o ordenamento do território.

\section{Sociedade civil e mídia}

Para atuarem de modo eficaz no seu papel de articular e mobilizar olhares e demandas para um governo responsável, reforçando a atuação das instituições que atuam na responsabilização horizontal, é fundamental que a sociedade civil e a mídia tenham acesso a informações sobre o desempenho e a gestão das áreas protegidas (GRAHAM; AMOS; PLUMPTRE, 2003). Ao olhar para fora do conselho gestor da APA Bororé-Colônia, há baixa efetividade da sociedade civil e da mídia em mobilizar as demandas por prestação de contas no que se refere à unidade de conservação.

Um dos programas de ação da APA Bororé-Colônia, previsto em seu Plano de Gestão, trata da comunicação e objetiva divulgar a unidade de conservação como instrumento de gestão no contexto territorial. A existência desse programa denota uma preocupação sobre a necessidade de se expandir a comunicação existente entre a APABC, seu conselho e a sociedade, e há muito trabalho para ser feito. Frente ao desafio de oferecer condições para que os cidadãos participem da formulação e aplicação das políticas públicas o conselho 
gestor da APA Bororé- Colônia tem potencial de ser um educador que deve instrumentalizar a sociedade civil para que possam participar da vida política e mudar sua realidade (LAYRARGUES, 2000)

A população residente na APA Bororé-Colônia não conhece os objetivos da área protegida, possui baixo padrão de desenvolvimento, enfrenta grandes desafios em seus cotidianos para sobreviver e manter suas famílias, e é, em sua maioria, desassistida pelo poder público. Esses cidadãos carecem de demandas tão primárias, como saúde, educação, saneamento básico, abastecimento e tais necessidades são tão preocupantes e envolventes que não os permite visualizar com clareza as relações benéficas que podem derivar do estabelecimento de uma unidade de conservação, como uma APA, no que tange à melhoria de sua qualidade de vida. Apenas enxergam obstáculos, pois esta é a realidade de seus cotidianos, gastando toda sua criatividade e energia para sobreviver.

Os movimentos da sociedade civil organizada, especialmente aqueles compostos pelos mais jovens, compõe o segmento da sociedade civil que, por possuírem maior articulação com as redes sociais, tem potencial de mobilizar mais olhares para a região, podendo mobilizar mais demandas por prestação de contas do poder público que tem responsabilidades de atuação no território da APA Bororé-Colônia. A tendência do uso do recurso tecnológico na difusão de informações é uma realidade atual que na maior parte das vezes oferece mais resistência para ser apropriada pelos cidadãos de mais idade. No caso dos conselheiros da APA Bororé-Colônia, os representantes das Associações de Bairro não têm afinidade com esses recursos e acabam tendo uma capacidade limitada de comunicação fora do conselho, atuando em um nível mais local, do bairro mesmo. Não se deseja de forma alguma desmerecer o papel desses conselheiros e cidadãos, pois eles também têm potencial de exercerem grande influência em âmbito local. Na medida em que o conselho permite que esses cidadãos passem a conhecer os representantes do poder público, bem como a localização dos seus escritórios, e tomar conhecimento de suas reais atribuições na APABC eles passam a ter mais possibilidades de cobrar a boa atuação do poder público no âmbito local.

A grande imprensa, os grandes veículos com reconhecida influência na população e no governo, e também os demais meios de comunicação em geral não voltaram seus olhares para a APA Bororé-Colônia, tampouco para seu conselho gestor. Para que isso ocorra é 
necessário fomento, articulação, além de fontes confiáveis. Em meio à crise hídrica que assola o estado de São Paulo, em especial a capital, a grande imprensa não deu grande publicidade ao fato das águas da Represa Billings estarem contaminadas por metais pesados. A grande imprensa atende a interesses de outros grupos hegemônicos que estão presentes no território da $A P A B C$ e ainda está longe de usar seu poder articulador e mobilizador em prol da unidade de conservação e dos hegemonizados. É necessária muita articulação dos conselheiros para atingir os grandes veículos de comunicação. O mais palpável no momento é atuar em parceria com os veículos e canais mais alternativos de comunicação, especialmente aqueles ligados a sociedade civil organizada.

\section{Transparência}

Transparência se relaciona com a capacidade dos cidadãos, da sociedade civil e da mídia em acessar informações relevantes para o desempenho da gestão da unidade de conservação e empregá-las com poder regulatório, elaborando e implementando normas para o controle da aplicação de recursos e esforços (GRAHAM; AMOS; PLUMPTRE, 2003). Para ajudar a pensar nessa complexa relação os autores Graham, Amos e Plumptre (2003) recorrem à pergunta: quem presta contas do quê, para quem e como?

Novamente temos de considerar que a APA Bororé-Colônia não possui recursos financeiros, então quando falamos em transparência na prestação de contas da APABC estamos falando de relações e de processos, como nos ajudam a entender Loureiro e Cunha (2008). Considerando os conselhos gestores de unidades de conservação enquanto momentos de educação e de exercício da cidadania, e a educação ambiental como fundamental na formação de processos educativos emancipatórios e participativos, os autores colocam a necessidade das ações de educação ambiental nas unidades de conservação exigirem

“ (...) transparência nas relações e nos processos instituídos entre os grupos sociais envolvidos com a gestão e o fortalecimento do Estado, sob controle social, para se garantir: 1) reversão dos processos privatistas-mercantis da natureza; 2) mobilização e organização popular para o atendimento a necessidades materiais básicas e à justiça distributiva, associado às necessidades de conservação (visando a sustentabilidade democrática); e 3) problematização historicizada da realidade socioambiental e busca de alternativas econômicas com os grupos sociais, particularmente aqueles em 
situação de maior vulnerabilidade socioambiental, garantindo a devida autonomia aos mesmos." (LOUREIRO; CUNHA, 2008, p. 243).

Os conselhos são espaços onde há interesses em disputas e os conflitos fazem parte de sua essência na medida em que existem diversos atores ali representados. A transparência, o acesso às relações e aos processos, ainda é incipiente no conselho gestor da APA Bororé-Colônia, embora a atual gestão empenhe esforços para implicar-lhe mais luz. 0 programa de educação ambiental permanente, que deve acompanhar o conselho gestor da APABC, conforme dispõe seu Regimento Interno, tem potencial para auxiliar o conselho a se apropriar dessa abordagem.

\subsection{Equidade}

A equidade dialoga com o complexo conceito de estado de direito, que, dentre outros fatores, tem como princípio que as leis devem ser claras, acessíveis, estáveis e pautadas em uma base moral; regula e restringe o comportamento dos funcionários públicos, impedindo que eles façam uso do poder arbitrário; defende os direitos dos indivíduos e fornece os recursos legais contra o governo caso esses direitos sejam violados; parte do princípio da independência judicial; prevê a igualdade de tratamento de todos os cidadãos perante a lei; busca a resolução neutra dos conflitos entre os interesses dos cidadãos e os interesses privados; e se fundamenta na Constituição de um país (GRAHAM; AMOS; PLUMPTRE, 2003).

No contexto das unidades de conservação esse princípio tem se relacionado mais ao respeito às comunidades tradicionais, povos indígenas e populações locais no desenvolvimento e manejo da área protegida, bem como no uso dos conhecimentos tradicionais na gestão da unidade de conservação (GRAHAM; AMOS; PLUMPTRE, 2003). A equidade tem colocado seus interesses nos benefícios obtidos a partir da descentralização do poder, tendo em vista sua capilarisação de modo mais localizado e o papel das áreas habitadas por comunidades tradicionais na manutenção dos ecossistemas naturais (GRAHAM; AMOS; PLUMPTRE, 2003).

Os critérios que constroem o princípio da equidade formam um contexto muito importante no qual o conselho gestor da APA Bororé-Colônia pode atuar, porém alguns 
destes critérios estão além do controle dos conselheiros e do gestor da unidade de conservação.

\section{Existência de um contexto de apoio judicial}

A existência de um contexto de apoio judicial é caracterizada pelo respeito ao Estado de direito, incluindo: Poder Judiciário independente, igualdade perante a Lei, exigência de que governos e seus funcionários baseiem suas ações em atribuições legais bem definidas, direito dos cidadãos em buscar garantias legais contra o governo e demais cidadãos (GRAHAM; AMOS; PLUMPTRE, 2003). Trata-se de um amplo critério que está muito além da capacidade de atuação do conselho e da APA Bororé-Colônia e se relaciona diretamente com a configuração do sistema democrático que se constituiu em nosso país.

As leis que incidem sobre o território da APA Bororé-Colônia não são de fácil compreensão para a população que habita a unidade de conservação, em especial para seus habitantes mais tradicionais, aqueles cujo referencial é mais ligado ao ambiente rural. Elas são complexas e se sobrepõe, conforme já fora mencionado. Além de não serem claras, há dificuldade de acesso tanto à legislação quanto ao esclarecimento por parte do poder público sobre sua aplicação e neste sentido o conselho gestor da APABC acaba por ser um espaço educativo, onde muitas dúvidas da população local podem ser esclarecidas na medida em que o poder público ali representado atue de forma qualitativa no fórum.

A já citada ausência de uma base física institucional da gestão da APA Bororé-Colônia em seu território é um empecilho para o contato direto dos moradores da unidade de conservação com o gestor da área protegida. É muito importante que pelo menos no âmbito das unidades de conservação e das subprefeituras os representantes do governo sejam rostos conhecidos e acessíveis para a comunidade, não sejam apenas instâncias imateriais. Nesse sentido, ainda há um caminho que pode se tornar mais curto entre a Secretaria do Verde e do Meio Ambiente e os moradores da APABC.

A igualdade de direitos de todos os cidadãos brasileiros é prevista constitucionalmente, conforme já fora mencionado nas páginas anteriores, cabendo ao poder público garantir essa equidade. Os processos concorrenciais na APA Bororé-Colônia já demonstraram que os interesses dos moradores locais muitas vezes não são respeitados, e 
há dificuldades em se garantir os direitos destes cidadãos contra o governo e contra aqueles cidadãos que representam interesses particulares, em detrimento do público ou coletivo. Nesse sentido, espera-se dos representantes do poder público que, adequando suas ações em atribuições legais, qualifiquem sua representação no conselho gestor da APA BororéColônia e pautem-na pela promoção desta equidade de direitos entre os cidadãos, garantindo que os não representados e os hegemonizados tenham suas demandas atendidas.

\section{Correção, imparcialidade e eficácia na aplicação de normas relativas à unidade de conservação}

Este critério inclui transparências das normas, com existência conhecida e acessível; ausência de corrupção entre funcionários públicos e direitos de recurso para aqueles acusados de transgressões (GRAHAM; AMOS; PLUMPTRE, 2003). Novamente é um critério muito complexo que perpassa os limites do conselho gestor da APA Bororé-Colônia e da referida unidade de conservação, ainda assim buscar-se-á, nas próximas linhas, com reconhecidas limitações, transpor a análise desse critério para o conselho gestor da APABC.

As normas relativas à unidade de conservação são conhecidas e acessíveis, embora complexas, conforme já fora mencionado. Sua aplicação está sujeita a atuação das redes de poder que empenham esforços em consolidar objetivos de atores de mercado no território da área protegida, atores estes nada interessados no bem comum, ao contrário, defendem interesses particulares. Haja vista que, desde a criação da APA Bororé-Colônia, manifestaram-se naquele território os interesses de grupos hegemônicos; afinal o trecho sul do Rodoanel Metropolitano Mário Covas ficou excluído da área da unidade de conservação, ainda que perpasse por toda a APABC, em uma concepção absurda do ponto de vista da conservação. Consiste em um "vácuo de território" na área protegida, sobre o qual não é possível aplicar as normas relativas à unidade de conservação.

No exercício de suas atribuições, o conselho gestor da APA Bororé-Colônia tem de considerar a correção, a imparcialidade e a eficácia na aplicação das normas relativas à unidade de conservação para emitir pareceres técnicos e manifestações sobre empreendimentos com potencial de causar impacto na APBC. Nestes pareceres, o conselho 
procura avaliar aquilo que é pertinente à $A P A B C$, como ela será afetada e como pode se resguardar minimamente. Trata-se de uma atividade complexa, que exige compreensão do território, dos atores sociais envolvidos, de aspectos ambientais, sociais, econômicos, geográficos, entre outros. Sem dúvida os conselheiros com menor escolaridade podem contribuir com seu conhecimento mais tradicional na construção das manifestações e jamais devem ser desconsiderados neste contexto, inclusive observou-se que estes sempre foram considerados. Porém, a presença de conselheiros com capacidade de construir argumentações técnicas e que tenha uma escrita concisa é fator chave para boas manifestações.

Durante este estudo, presenciou-se a consulta e manifestação do conselho sobre dois empreendimentos: o Aeródromo Harpia e a Dutovia Logum. O Aeródromo Harpia, também chamado de Aeroporto de Parelheiros ou de Aeródromo Privado Rodoanel, seria o terceiro aeroporto na cidade de São Paulo, tendo sua capacidade voltada para atender a aviação executiva, operação de helicópteros e serviços de taxi aéreo. A Presidência da República, por intermédio da Secretaria de Aviação Civil da Presidência da República, emitiu, em abril de 2013, a concessão para a exploração do aeródromo civil, que diz respeito apenas a áreas para pousos e decolagens. As autorizações ambientais e de ocupação do solo são de responsabilidade do governo estadual e municipal. A previsão de início das obras era para meados de 2015, porém até o momento a obra encontra-se envolta em muitas polêmicas e em uma resistência social que tem postergado seu início. O local prospectado para o empreendimento fica entre as APA Bororé-Colônia e Capivari-Monos e o Parque Estadual da Serra do Mar, e seus impactos no território das UCs são indiscutíveis. A região do empreendimento é definida como Zona Especial de Preservação Ambiental (Zepam) na Lei de Uso e Ocupação do Solo (Lei Municipal no 13.885/2004), o que impossibilitou até meados de 2014 a construção de grandes empreendimentos. No novo Plano Diretor Estratégico, após doze anos de extinção, a Zona Rural foi recriada e o empreendimento se insere nesta porção do território. O conselho gestor da APA Bororé-Colônia manifestou seu apoio à resistência à construção do Aeródromo Harpia em uma decisão tranquilamente consensual.

Já a manifestação sobre a Dutovia Logum foi um pouco mais conflituosa, talvez porque a decisão tomada no parecer técnico do conselho gestor da APA Bororé-Colônia tenha sido mais estratégica e alguns conselheiros não conseguiram entendê-la como tal, 
dada a sua complexidade. A Dutovia Logum consiste em corredores de transporte dutoviário e hidroviário de etanol, que funcionarão com os sistemas de distribuição nas regiões Sudeste e Centro-Oeste do país. Um dos seus trechos de implantação sobrepõe o trecho sul do Rodoanel Metropolitano Mário Covas, que, embora não esteja legalmente dentro dos limites da APA Bororé-Colônia, talha a unidade de conservação em dois fragmentos. Trata-se de um licenciamento em nível estadual, pois é uma obra que ultrapassa muitos municípios. O entendimento do conselho da APABC era contrário ao traçado eleito dentro do município de São Paulo, porém, como o conselho reconhece que não possui poder suficiente para exigir a alteração do traçado, os conselheiros optaram por priorizar as condicionantes no documento. Ou seja, tiveram que decidir estrategicamente para não desperdiçar o parecer. Um parecer negativo, naquele caso, seria um documento perdido, pois dificilmente o órgão licenciador ${ }^{91}$ levaria em conta a negativa do conselho. O traçado já estava decidido, e o conselho só poderia empenhar essa iniciativa de mudá-lo se a APABC tivesse o devido empoderamento de fazer valer sua decisão política. Porém, nem todos conselheiros entenderam essa estratégia e essa foi a única situação durante a pesquisa onde se presenciou uma votação no colegiado para definir qual seria o encaminhamento. Os Parques Naturais Municipais Jaceguava, Itaim, Bororé e Varginha não foram considerados no EIA/RIMA por serem muito novos e ainda não estarem inseridos no cadastro nacional de UCs, o que é muito conveniente para os empreendedores. O parecer técnico do conselho gestor da APA Bororé-Colônia chamou a atenção do órgão licenciador para esse cenário.

A APA Bororé-Colônia tem inúmeros obstáculos para conseguir priorizar a aplicação do recurso oriundo dessa compensação ambiental em seu território. Os conselheiros precisariam ir além do seu fórum, fazer um lobby na câmara de compensação ambiental e participar das audiências públicas para o licenciamento visando ampliar suas chances de empreender algum sucesso. Neste sentido, percebe-se como é importante que o conselho gestor da APABC promova a articulação entre órgãos governamentais, sociedade civil e organizações não governamentais para atingir seus objetivos, caso negativo não conseguirá usufruir das beneficies que os recursos oriundos dos termos de compensação ambiental e de ajustes de conduta podem oferecer para a gestão da APABC. Destaca-se que não deseja neste estudo estimular esse cenário no qual as unidades de conservação só consigam

\footnotetext{
${ }^{91}$ Cabe a Companhia de Tecnologia de Saneamento Ambiental (CETESB), ligada a Secretaria de Meio Ambiente do Estado de São Paulo, o licenciamento ambiental deste tipo de empreendimento.
} 
recursos para cumprirem com seus objetivos de gestão a partir de obras que irão causar impactos ambientais, pois isso é contraditório. Porém, reconhece-se que atualmente o poder público não tem oferecido nenhum recurso financeiro para a manutenção da APABC e, dado o cenário atual, a compensação ambiental advinda da implantação da Dutovia Logum pode contribuir para que o conselho gestor da APABC possa gerenciar sua aplicação tendo em vista o cumprimento de suas demandas e a consolidação dos objetivos de gestão da APABC.

Com relação à corrupção, Bernardelli (2013), em seu estudo que aborda os impactos do Rodoanel Metropolitano Mário Covas em seu Trecho Sul, cita uma reportagem onde o Tribunal de Contas da União havia apontado indícios de superfaturamento da obra, como é de praxe em obras de grande porte na história de nosso país. Por vezes o RMMC é referenciado nesse estudo, talvez seja porque seus impactos sociais são fortes e constantes, quiçá porque ele se relacione com a APA Bororé-Colônia desde a criação da unidade de conservação, conforme exposto no capítulo que trata da APABC. Fato é que o RMMC tem trazido impactos para a APABC, a questão que se coloca, ainda sem resposta, é se o conselho conseguirá se apropriar de beneficies provenientes da existência do RMMC?

\section{Equidade na criação de novas unidades de conservação}

A equidade na criação de novas unidades de conservação pressupõe respeito aos direitos, usos e conhecimentos tradicionais das comunidades locais e povos indígenas ligados com a área; uma avaliação de outras opções para a utilização da área; a participação pública no processo de criação da unidade de conservação, incluindo principalmente as comunidades locais e os povos indígenas; e o equilíbrio adequado entre os objetivos da unidade de conservação (GRAHAM; AMOS; PLUMPTRE, 2003). Optou-se por fazer uma análise da criação dos Parques Naturais Municipais Itaim, Bororé, Varginha e Jaceguava para analisar esse critério, pois o conselho gestor da APA Bororé-Colônia foi o fórum de participação social na criação dessas unidades de conservação.

A criação dos Parques Naturais Municipais Jaceguava, Itaim, Bororé e Varginha, advindos da compensação ambiental do trecho sul do Rodoanel Metropolitano Mário Covas tem uma frágil equidade. Todos foram concebidos a partir de um acordo entre a Secretaria 
do Verde e do Meio Ambiente e a Desenvolvimento Rodoviário S.A. (DERSA), a partir de estudos técnicos norteados pela conservação de remanescentes florestais e várzeas ainda preservadas próximos das rodovias e das áreas de ocupação urbana (RADOLL, 2014). Conforme relata Radoll (2014, p. 101) "na audiência realizada em maio de 2011 para a discussão das UCS a serem criadas, os parques já estavam em processo de cercamento. Assim, os limites e a existência própria das UCs já estavam definidas".

Como já fora citado nas páginas anteriores, em especial no capitulo 3.2., as consultas públicas para a criação das unidades de conservação são previstas no Sistema Nacional de Unidades de Conservação (BRASIL, 2000). Mas, está muito a cargo do poder público o encaminhamento do que será demandado pela sociedade civil, conforme pode ser observado no texto da íntegra do "Roteiro para Criação de Unidades de Conservação Municipais", elaborado pelo Ministério do Meio Ambiente em 2010, que prevê que:

a consulta pública tem caráter estritamente consultivo, as propostas apresentadas pelos participantes da consulta pública serão incorporadas ao processo de criação da unidade para avaliação técnica do órgão responsável pela criação. Nessa etapa a população poderá apresentar formalmente suas demandas, seja para inclusão ou exclusão de áreas, favorável ou contrária à criação da unidade. Todas as demandas encaminhadas deverão ser respondidas tecnicamente. A decisão final no processo de criação compete ao poder público (MMA, 2010, p. 27).

Buscou-se envolver lideranças locais, a sociedade civil organizada, os conselheiros da APA Bororé-Colônia e os órgãos públicos em uma divulgação que coube a Secretaria do Verde e do Meio Ambiente (RADOLL, 2014). Não se tem clareza de como a Prefeitura buscou esse envolvimento, as evidências sugerem que ele foi ineficaz. As oficinas públicas, tanto de planejamento do traçado das unidades de conservação quanto dos Planos de Manejo, eram vazias ou ocupadas por atores cuja presença era intermitente (RADOLL, 2014). Embora exista uma tímida mobilização social na região construída por associações da sociedade civil organizada que se relacionam com a temática socioambiental, bem como por cidadãos inquietos diante da grande presença de demandas sociais na região, eles não demandaram participação no processo de criação dessas unidades de conservação. Além da baixa mobilização, Radoll (2014) acredita que fatores como pouca disponibilidade de tempo para a 
realização dos estudos, a escassez de recursos financeiros para esta mobilização, os entraves da agenda política estabelecida aos processos, somados a não existência dos parques naquele momento podem ter atrapalhado a participação nas reuniões.

Muitas áreas onde foram implantados os parques eram dotadas de outros usos pelas populações locais (RAIMUNDO, et. al., 2010). Na região que originou o Parque Natural Municipal do Itaim muitos sítios desapropriados eram casas de segunda residência, voltados à recreação, cujos caseiros e suas famílias optaram, em um primeiro momento, por permanecer no local, pois não haviam chegado a um acordo com o proprietário que recebera a indenização (RADOLL, 2014). Esses moradores tradicionais não foram indenizados porque não detinham o título legal de propriedade da terra que habitavam, e simplesmente foram expulsos de suas moradias (RADOLL, 2014). No máximo conseguiram estabelecer algum tipo de indenização com seus "patrões" pelo tempo de serviço e não pelo direito de permanência ou de posse daquela porção do território (RADOLL, 2014).

No caso ainda do Parque Natural Municipal do Itaim, os estudos feitos pela equipe de infraestrutura para o Plano de Manejo que iriam indicar algumas infraestruturas para permanecerem conservadas devido a seu potencial de novo uso ou a sua relevância para a comunidade local, não emplacaram sucesso (RADOLL, 2014). Estes ocorreram após a desapropriação de muitos sítios, e fatores como a cultura de obra de demolir após a desapropriação, somados ao vandalismo e aos furtos comprometeram a estrutura de muitas edificações que acabaram sendo demolidas antes da manifestação da equipe técnica (RADOLL, 2014).

Há que se mencionar um caso de sucesso na resistência ao processo de desapropriação, trata-se do Centro Paulus, um espaço de cultura antroposófica criado em 1981 que oferece estrutura de hospedagem e abriga uma galeria de arte, que a partir da mobilização junto à sociedade civil e ao poder público conseguiu empreender sucesso e manter-se (RADOLL, 2014). Atualmente é um parceiro dos Parques Naturais Municipais, bem como da APA Bororé-Colônia (RADOLL, 2014).

Os estudos que subsidiaram os Programas de Uso Público dos Planos de Manejo das referidas unidades de conservação foram pautados no objetivo de compatibilizar as necessidades e aspirações de lazer das comunidades com as ações de conservação dos 
parques (RAIMUNDO et al., 2010). Esses programas foram pautados no respeito aos direitos e usos das comunidades locais, equilibrando-os adequadamente aos objetivos das unidades de conservação. Porém, a ausência de recursos humanos e financeiros para viabilizarem a abertura dos parques, para concretizá-los, descarrega boa parte da energia concentrada. Resta às minorias apenas as restrições da imposição das áreas protegidas. Conforme citado anteriormente, os Planos de Manejo dos Parques ainda não foram entregues.

\section{Equidade na gestão de unidades de conservação}

A equidade na gestão das unidades de conservação inclui: práticas que obtenham um equilíbrio favorável entre custos e benefícios para a comunidade local e para os povos indígenas; mecanismos que permitam ceder ou compartilhar as tomadas de decisão da gestão da unidade de conservação com as comunidades locais e povos indígenas; emprego de conhecimento e métodos de gestão de recursos tradicionais; práticas de gestão de recursos humanos equitativos para a equipe da UC; processo de reconhecimento e de trato com as injustiças do passado resultantes da criação e implantação da UC (GRAHAM; AMOS; PLUMPTRE, 2003). Sem dúvida a discussão que esse critério pressupõe perpassa pelo entendimento, trazido por algumas vezes ao longo deste estudo, de que o Estado deve promover a igualdade de direito entre todos os cidadãos, garantindo que os não representados, os hegemonizados, sejam considerados na tomada de decisão e atuação do poder público na APA Bororé-Colônia.

Sem dúvida os gestores da APA Bororé-Colônia acompanhados neste estudo empenharam um grande esforço em promover a equidade na gestão da unidade de conservação, especialmente no que diz respeito a sua liderança no conselho gestor e na sua articulação junto a Secretaria do Verde e do Meio Ambiente. Eles são o ponto de encontro entre a sociedade civil e o poder público. Existe entre estes técnicos uma preocupação em minimizar os impactos sofridos pelas comunidades locais. Por intermédio do "Grupo de Trabalho Água do Poços da Ilha do Bororé" do conselho gestor, por exemplo, houve a promoção de oficinas de promoção à saúde em áreas carentes de saneamento. Os agentes de saúde foram capacitados por técnicos de diferentes pastas do poder público. Como projeção, a expectativa é expandir as oficinas para as comunidades da llha do Bororé que 
sofrem com as águas contaminadas da Represa Billings. O conselho também manifestou grande apoio aos agricultores reivindicando a permanência da Feira de Orgânicos localizada no Melódromo do Parque do Ibirapuera. Estimulou, apoiou e divulgou manifestações culturais da região empenhando esforços em promover a Festa das APA em 2014 e também em celebrar a VI Rota do Cambuci. Apoiou as Cooperativas de Reciclagem no encaminhamento de suas pautas. Apoiou o turismo de base comunitária, aquele desenvolvido e gerido pela comunidade local, em especial por agricultores adeptos de práticas agroecológicas que procuram receber visitantes em suas propriedades.

Para o futuro próximo, o conselho gestor da APA Bororé-Colônia tem perspectivas de atuação focadas na promoção da geração de renda e fomento às práticas tradicionais. Essas ações encontraram oportunidades de serem semeadas por conta do campo fértil, porém frágil, que esses gestores formaram. Foram contempladas no Plano de Gestão 2013-2015 da APABC, mas precisam ser institucionalizadas no Plano de Manejo da unidade de conservação e encampadas pela Secretaria do Verde e do Meio Ambiente, pelas demais instituições do governo e pelos conselheiros.

Quanto aos mecanismos que permitem compartilhar a gestão da APA Bororé-Colônia com as comunidades tradicionais, sem dúvidas o mais importante deles é o conselho gestor objeto de análise deste estudo. Salvo todos os desafios enfrentados, o conselho gestor da APABC tem seu papel como espaço que promove a participação de setores representativos da sociedade civil organizada que habita ou se relaciona com a unidade de conservação, e como espaço que coloca essas pessoas no centro das demandas das deliberações. Por muitas vezes, com todas as limitações apontadas, o conselho delibera para as minorias, para os agricultores adeptos da agricultura orgânica, para os moradores tradicionais. O insucesso está além das reuniões daquele fórum, na efetivação do que ali é deliberado que irá envolver outros atores do governo e, algumas vezes, da sociedade civil.

\subsection{Síntese dos resultados obtidos}

A análise realizada do conselho gestor da APA Bororé-Colônia com base nos princípios e critérios de "boa" governança propostos pelos atores Graham, Amos e Plumptre (2003) demonstrou-se densa e descritiva. No intuito de atribuir alguma feição de síntese a esta apreciação, e pautando-se pelo destaque de aspectos que foram mais proeminentes ao 
longo do estudo, foi desenvolvido o quadro 8, adiante. Neste quadro utilizou-se de diferentes cores para atribuir valores diferenciados para o que foi mencionado dentro de cada critério de análise. A legenda, sistematizada no início do quadro, indica variáveis que tratam um problema ou um desafio como grave, médio ou tênue e abordam o avanço ou a conquista como muito significativa, significativa ou tênue. 
Quadro 8: Síntese da análise sobre os princípios e critérios da "boa" governança (GRAHAM; AMOS; PLUMPTRE, 2003) aplicados ao conselho gestor da APA Bororé-Colônia Legitimidade e Voz. Continua.

\begin{tabular}{|c|c|}
\hline \multicolumn{2}{|c|}{ Legenda } \\
\hline Problema ou Desafio & Virtude \\
\hline Grave & muito significativo \\
\hline Médio & Significativo \\
\hline Tênue & Tênue \\
\hline
\end{tabular}

\begin{tabular}{|c|c|c|c|}
\hline PRINCÍPIO & CRITÉRIO & PRINCIPAL PROBLEMA OU DESAFIO & PRINCIPAL VIRTUDE \\
\hline \multirow{5}{*}{ 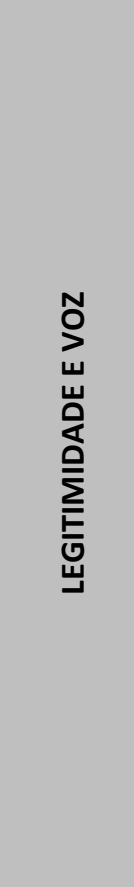 } & $\begin{array}{l}\text { Existência de contexto de } \\
\text { suporte democrático e de } \\
\text { direitos humanos }\end{array}$ & $\begin{array}{l}\text { Há baixa renovação nas cadeiras da sociedade civil } \\
\text { organizada, desinteresse das pessoas na vida política, a } \\
\text { representatividade é muito frágil e o contexto de livre } \\
\text { associação distante. }\end{array}$ & $\begin{array}{l}\text { Existe contexto de suporte democrático para a eleição dos } \\
\text { representantes da sociedade civil. Há respeito aos direitos } \\
\text { humanos e aos habitantes locais. O direito a voz é garantido } \\
\text { a todos. }\end{array}$ \\
\hline & $\begin{array}{l}\text { Grau apropriado de } \\
\text { descentralização na tomada de } \\
\text { decisões nas unidades de } \\
\text { conservação }\end{array}$ & $\begin{array}{c}\text { As estruturas de prestação de contas são inexistentes. A } \\
\text { SVMA tem apresentado baixo poder e baixa capacidade em } \\
\text { articular para que o poder público tenha uma atuação mais } \\
\text { efetiva na APABC. }\end{array}$ & $\begin{array}{c}\text { Há uma gestão descentralizada e participativa na medida em } \\
\text { que se institucionalizou um conselho gestor deliberativo, } \\
\text { embora ele não atue como tal na prática pelos desafios que } \\
\text { enfrenta. }\end{array}$ \\
\hline & $\begin{array}{l}\text { Gestão participativa nas } \\
\text { tomadas de decisão da unidade } \\
\text { de conservação }\end{array}$ & $\begin{array}{l}\text { O poder público representado no conselho atua com baixa } \\
\text { qualidade no colegiado. A sociedade civil enfrenta } \\
\text { dificuldades na legitimidade da relação entre representantes } \\
\text { e representados. }\end{array}$ & $\begin{array}{l}\text { Existe paridade entre poder público e sociedade civil na } \\
\text { composição das cadeiras do conselho. }\end{array}$ \\
\hline & $\begin{array}{l}\text { Participação dos cidadãos } \\
\text { ocorrendo em todos os níveis de } \\
\text { tomada de decisão relacionados } \\
\text { à unidade de conservação }\end{array}$ & $\begin{array}{l}\text { Os projetos concorrenciais são constantes no território da } \\
\text { APABC e a organização social ainda é incipiente para que a } \\
\text { sociedade imponha decisões que partam do seu âmago. }\end{array}$ & $\begin{array}{l}\text { Há a presença de gestores que são democráticos e que } \\
\text { promovem e oportunizam a participação dos cidadãos na } \\
\text { gestão ambiental pública. Há potencial para o fortalecimento } \\
\text { da rede que se formou a partir do conselho gestor da APABC. }\end{array}$ \\
\hline & $\begin{array}{l}\text { Existência de associações civis e } \\
\text { mídia independente }\end{array}$ & $\begin{array}{l}\text { A rede entre as associações civis e a mídia independente } \\
\text { precisa fortalecer sua articulação para exercer mais } \\
\text { influência no poder decisório das lideranças políticas. }\end{array}$ & $\begin{array}{l}\text { Existem ONGs, movimentos sociais e associações civis no } \\
\text { território da APABC, alguns representados em seu conselho } \\
\text { gestor, que fazem uso da internet e das redes sociais para } \\
\text { ampliar sua atuação e seu poder político. }\end{array}$ \\
\hline
\end{tabular}

Fonte: Autora. 2015. 
Quadro 8: Síntese da análise sobre os princípios e critérios da "boa" governança (GRAHAM; AMOS; PLUMPTRE, 2003) aplicados ao conselho gestor da APA Bororé-Colônia Direcionamento. Continua.

\begin{tabular}{|c|c|c|c|}
\hline PRINCÍPIO & CRITÉRIO & PRINCIPAL PROBLEMA OU DESAFIO & PRINCIPAL AVANÇO OU CONQUISTA ALCANÇADA \\
\hline 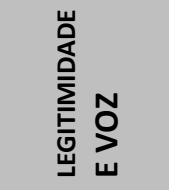 & $\begin{array}{l}\text { Alto nível de confiança entre os } \\
\text { vários atores envolvidos no } \\
\text { manejo da unidade de } \\
\text { conservação }\end{array}$ & $\begin{array}{c}\text { A gestão do território da APABC é feita por vários atores } \\
\text { governamentais e não governamentais, em um nível que vai } \\
\text { do nacional ao municipal e há baixa qualidade na relação de } \\
\text { confiança entre estes atores. }\end{array}$ & $\begin{array}{l}\text { A sociedade tem poder de pressão política e pode e deve } \\
\text { acompanhar o desenvolvimento de políticas públicas que } \\
\text { beneficiem os cidadãos e a conservação da APABC. }\end{array}$ \\
\hline \multirow{5}{*}{ 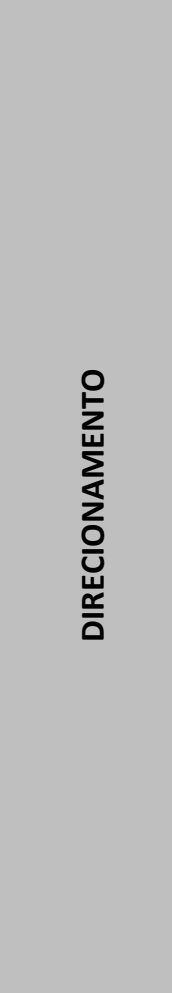 } & $\begin{array}{l}\text { Conformidade com o } \\
\text { direcionamento internacional } \\
\text { relativo às unidades de } \\
\text { conservação }\end{array}$ & $\begin{array}{l}\text { As Convenções Internacionais, Acordos Governamentais e } \\
\text { Acordos Regionais não são temas presentes na agenda do } \\
\text { conselho gestor da APABC, portanto os conselheiros não } \\
\text { enxergam sua aderência na gestão da UC. }\end{array}$ & $\begin{array}{c}\text { A APA Bororé-Colônia é integrante da Reserva da Biosfera do } \\
\text { Cinturão Verde. Há boa interface entre os gestores das UC } \\
\text { do extremo sul, embora não haja uma política integrada } \\
\text { entre a FF e a SVMA. }\end{array}$ \\
\hline & $\begin{array}{l}\text { Existência de direcionamento } \\
\text { legislativo }\end{array}$ & $\begin{array}{l}\text { Os instrumentos legais existem, porém não funcionam na } \\
\text { prática; a APABC não possui Plano de Manejo, não possui } \\
\text { zoneamento geoambiental e nunca foram provisionados } \\
\text { recursos financeiros para sua gestão. }\end{array}$ & $\begin{array}{l}\text { Existe direcionamento legislativo no conselho, os } \\
\text { instrumentos incluem exigências para que os cidadãos } \\
\text { participem da tomada de decisão e estão elaborados na } \\
\text { forma de proposição escritas. }\end{array}$ \\
\hline & $\begin{array}{l}\text { Existência de um sistema } \\
\text { nacional de unidades de } \\
\text { conservação planejado }\end{array}$ & $\begin{array}{l}\text { Não há uma política institucionalizada de integração entre a } \\
\text { gestão das UC que existem no extremo sul do município de } \\
\text { São Paulo. O distanciamento entre as UC municipais, e } \\
\text { entras estas e a UC estadual (PESM) é recíproco. }\end{array}$ & $\begin{array}{c}\text { Existe potencial para se institucionalizar um mosaico de UC } \\
\text { na região da APABC e há indícios do início de uma gestão } \\
\text { mais integrada entre as APA municipais e os Parques } \\
\text { Naturais Municipais. }\end{array}$ \\
\hline & $\begin{array}{l}\text { Existência de plano de gestão } \\
\text { individualizado }\end{array}$ & $\begin{array}{l}\text { A APABC e os Parques Naturais Municipais Itaim, Bororé, } \\
\text { Varginha e Jaceguava não contam com Planos de Manejo. }\end{array}$ & $\begin{array}{l}\text { Foi elaborado emergencialmente um Plano de Gestão da } \\
\text { APABC para a gestão do conselho de } 2013 \text { a } 2015 .\end{array}$ \\
\hline & $\begin{array}{l}\text { Demonstração de liderança } \\
\text { efetiva }\end{array}$ & $\begin{array}{c}\text { O cargo de gestor de UC municipal é desvalorizado, tem } \\
\text { baixa remuneração, ausência de plano de carreira e trata-se } \\
\text { de um cargo comissionado, sujeito a indicação de cabos } \\
\text { eleitorais. }\end{array}$ & $\begin{array}{l}\text { A APABC teve, e ainda tem, gestores responsáveis com visão } \\
\text { inspiradora e consistente ao desenvolvimento da UC. }\end{array}$ \\
\hline
\end{tabular}


Quadro 8: Síntese da análise sobre os princípios e critérios da "boa" governança (GRAHAM; AMOS; PLUMPTRE, 2003) aplicados ao conselho gestor da APA Bororé-Colônia Desempenho. Continua.

\begin{tabular}{|c|c|c|c|}
\hline PRINCÍPIO & CRITÉRIO & PRINCIPAL PROBLEMA OU DESAFIO & PRINCIPAL VIRTUDE \\
\hline \multirow{8}{*}{ 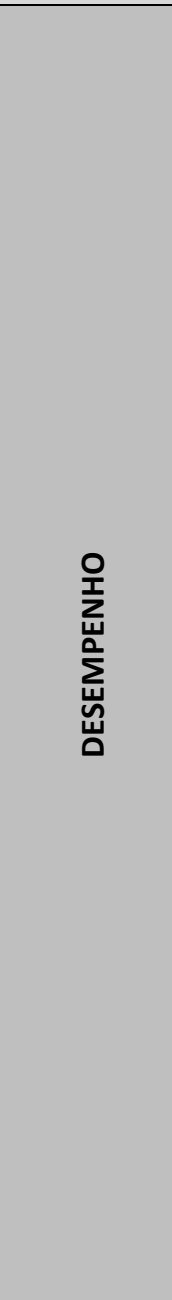 } & Eficiência em atingir objetivos & $\begin{array}{c}\text { O conselho gestor da APABC não possui Plano de Manejo e } \\
\text { orçamento. Também enfrenta problemas de legitimidade } \\
\text { que trasncendem a relação entre representantes e } \\
\text { representados. }\end{array}$ & $\begin{array}{l}\text { O conselho é espaço de nexo entre a sociedade civil e o } \\
\text { poder público que atua na APABC e fomenta a promoção da } \\
\text { consciência e um novo modelo de desenvolvimento. }\end{array}$ \\
\hline & Capacidade & $\begin{array}{l}\text { O conselho gestor não reconhece a necessidade da APABC } \\
\text { contar com um orçamento financeiro para poder ampliar } \\
\text { suas possibilidades de atuação como gestor de ações e } \\
\text { projetos. As necessidades das populações locais enfrentam } \\
\text { grandes dificuldades para serem encaminhadas. }\end{array}$ & $\begin{array}{l}\text { A educação ambiental é trabalhada de forma local e } \\
\text { contínua a partir dos Núcleos Verdes ligados a SVMA. }\end{array}$ \\
\hline & Coordenação & $\begin{array}{l}\text { A governabilidade parcial da APA demanda articulação entre } \\
\text { os órgãos do poder público. Essa articulação tem sido muito } \\
\text { incipiente para cumprir o que é deliberado no conselho. }\end{array}$ & $\begin{array}{l}\text { As cadeiras do conselho preveem a presença de importantes } \\
\text { atores sociais representantes do poder público e da } \\
\text { sociedade civil que atuam no território da APABC. }\end{array}$ \\
\hline & $\begin{array}{c}\text { Informações ao público sobre o } \\
\text { desempenho }\end{array}$ & $\begin{array}{l}\text { Não existe um canal de comunicação contínuo entre o } \\
\text { conselho gestor e os habitantes da APABC. É necessário mais } \\
\text { comunicação entre o conselho e os órgãos governamentais. }\end{array}$ & $\begin{array}{l}\text { O uso do recurso tecnológico por parte dos conselheiros é } \\
\text { uma oportunidade real de ampliar os canais de } \\
\text { comunicação. Os conselheiros da APABC se preocupam com } \\
\text { a transparência da comunicação com a sociedade civil. }\end{array}$ \\
\hline & Responsividade & $\begin{array}{l}\text { Os representantes do poder público frequentemente não } \\
\text { conseguem dar respostas a problemas recorrentes da } \\
\text { comunidade que emergem no conselho gestor da APABC, } \\
\text { desmotivando os conselheiros da sociedade civil. }\end{array}$ & $\begin{array}{l}\text { Embora desmotivados e frente a baixa renovação das } \\
\text { cadeiras os mesmos representantes de segmentos da } \\
\text { sociedade civil organizada continuam frequentando as } \\
\text { reuniões do conselho, as vezes por mais de uma gestão. }\end{array}$ \\
\hline & Monitoramento e Avaliação & $\begin{array}{c}\text { O conselho gestor da APABC precisa evoluir em aspectos } \\
\text { estruturais da gestão ambiental pública para poder avançar } \\
\text { rumo aos estabelecimento de indicadores de } \\
\text { monitoramento e avaliação. }\end{array}$ & $\begin{array}{l}\text { A elaboração do Relatório Executivo Anual no final do ano de } \\
2014 \text { demonstra preocupação com o tema. }\end{array}$ \\
\hline & Gestão adaptativa & $\begin{array}{l}\text { A história do conselho é muito recente e os problema já } \\
\text { apresentados neste quadro, principalmente no tocante a } \\
\text { legitimidade e a qualidade da representação do poder } \\
\text { público, são grandes empecilhos a gestão adaptativa. }\end{array}$ & $\begin{array}{c}\text { Há uma gestão adaptativa que ocorre de maneira empírica, } \\
\text { pautada na experiência e na observação, além do esforço } \\
\text { por parte do gestor da UC em se adaptar com os escassos } \\
\text { recursos que possui. }\end{array}$ \\
\hline & Gerenciamento de riscos & $\begin{array}{l}\text { A identificação dos riscos não está na pauta do conselho e } \\
\text { demanda amadurecimento. }\end{array}$ & $\begin{array}{c}\text { O conselho reconhece que precisa ampliar seu olhar e } \\
\text { capacidade de desempenho. }\end{array}$ \\
\hline
\end{tabular}


Quadro 8: Síntese da análise sobre os princípios e critérios da "boa" governança (GRAHAM; AMOS; PLUMPTRE, 2003) aplicados ao conselho gestor da APA Bororé-Colônia Prestação de contas. Continua.

\begin{tabular}{|c|c|c|c|}
\hline PRINCÍPIO & CRITÉRIO & PRINCIPAL PROBLEMA OU DESAFIO & PRINCIPAL VIRTUDE \\
\hline \multirow{6}{*}{ 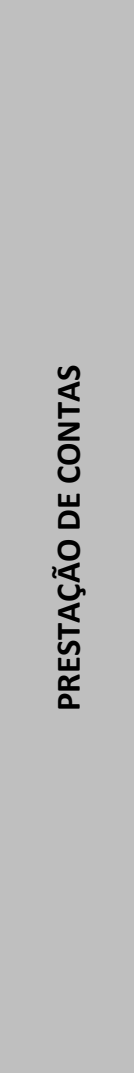 } & Clareza & $\begin{array}{l}\text { Os habitantes da APABC não compreendem com clareza a } \\
\text { atribuição de responsabilidades e autoridade dos diferentes } \\
\text { órgãos do poder público para agir sobre a área protegida. }\end{array}$ & $\begin{array}{l}\text { O conselho gestor da APABC existe como espaço colegiado } \\
\text { que permite, a partir de uma representação qualitativa do } \\
\text { poder público, ser um local de aprendizagem social, entre } \\
\text { outros fatores, das atribuições do governo na UC. }\end{array}$ \\
\hline & Coerência e visão & $\begin{array}{c}\text { O conselho gestor da APABC necessita primeiro avançar em } \\
\text { processos internos para depois poder voltar seus olhares } \\
\text { para além do colegiado e para o futuro. }\end{array}$ & $\begin{array}{l}\text { O conselho gestor da APABC reconhece que existem } \\
\text { oportunidades de maior conectividade da APABC com o } \\
\text { direcionamento internacional relativo as UCs e de uma } \\
\text { gestão mais integrada das UCs do extremo sul. }\end{array}$ \\
\hline & Papel dos líderes políticos & $\begin{array}{l}\text { O conselho gestor da APABC precisa primeiro amadurecer } \\
\text { para poder enxergar e cobrar a adequação das } \\
\text { responsabilidades atribuídas aos cargos eletivos em } \\
\text { contraposição aos não eletivos. }\end{array}$ & $\begin{array}{l}\text { Por se tratar de uma APA municipal alguns atores políticos } \\
\text { são identificados com maior facilidade, por terem uma } \\
\text { atuação mais local. }\end{array}$ \\
\hline & $\begin{array}{l}\text { Instituições públicas de } \\
\text { prestações de contas }\end{array}$ & $\begin{array}{c}\text { Os assuntos ligados a APABC não ocupam grande espaço na } \\
\text { agenda das instituições públicas impostas pelo e para o } \\
\text { governo visando sua prestação de contas. }\end{array}$ & $\begin{array}{c}\text { Existe uma preocupação do conselho em ir além da } \\
\text { responsabilização vertical e atingir a responsabilização } \\
\text { horizontal. }\end{array}$ \\
\hline & Sociedade civil e mídia & $\begin{array}{c}\text { A sociedade civil residente na APABC em geral não conhece a } \\
\text { UC e não compartilha dos seus objetivos de gestão. A grande } \\
\text { imprensa atende a interesses de grupos hegemônicos e não } \\
\text { utiliza seu poder articulador em prol da APABC. }\end{array}$ & $\begin{array}{l}\text { Há grande potencial do conselho gestor da APABC como } \\
\text { espaço educativo que deve instrumentalizar a sociedade civil } \\
\text { para que possam participar da gestão ambiental pública. }\end{array}$ \\
\hline & Transparência & $\begin{array}{l}\text { A transparência, o acesso às relações e aos processos } \\
\text { relativos à gestão da APABC ainda são incipientes em seu } \\
\text { conselho gestor, na sociedade civil e na mídia. }\end{array}$ & $\begin{array}{c}\text { O conselho gestor da APABC é um momento de educação e } \\
\text { de exercício da cidadania, a educação ambiental prevista em } \\
\text { lei é fundamental para a formação de processos educativos } \\
\text { emancipatórios e participativos. }\end{array}$ \\
\hline
\end{tabular}

Fonte: Autora. 2015. 
Quadro 8: Síntese da análise sobre os princípios e critérios da "boa" governança (GRAHAM; AMOS; PLUMPTRE, 2003) aplicados ao conselho gestor da APA Bororé-Colônia Equidade. Conclusão.

\begin{tabular}{|c|c|c|c|}
\hline PRINCÍPIO & CRITÉRIO & PRINCIPAL PROBLEMA OU DESAFIO & PRINCIPAL VIRTUDE \\
\hline \multirow{4}{*}{ 岁 } & $\begin{array}{l}\text { Existência de um contexto de } \\
\text { apoio judicial }\end{array}$ & $\begin{array}{l}\text { Os representantes do poder público devem qualificar sua } \\
\text { representação no conselho e promover a equidade de } \\
\text { direitos entre os cidadãos. }\end{array}$ & $\begin{array}{l}\text { A Constituição Federal prevê a igualdade de direitos de } \\
\text { todos os cidadãos brasileiros. }\end{array}$ \\
\hline & $\begin{array}{l}\text { Correção, imparcialidade e } \\
\text { eficácia na aplicação das normas } \\
\text { relativas à unidade de } \\
\text { conservação }\end{array}$ & $\begin{array}{l}\text { Interesses de grupos hegemônicos manifestam-se com muita } \\
\text { força no território da APABC; o trecho sul do RMMC ficou } \\
\text { excluído da área da UC. }\end{array}$ & $\begin{array}{l}\text { Na manifestação frente a empreendimentos que possam } \\
\text { causar impacto na APABC os conselheiros procuram avaliar o } \\
\text { que é pertinente a UC, como ela será afetada e como a APA } \\
\text { pode se resguardar, em um posicionamento estratégico. }\end{array}$ \\
\hline & $\begin{array}{l}\text { Equidade na criação de novas } \\
\text { unidades de conservação }\end{array}$ & $\begin{array}{c}\text { Os PNMs Itaim, Jaceguava, Bororé e Varginha foram } \\
\text { implantados sem ampla participação social e encontram-se } \\
\text { fechados para o acesso público. }\end{array}$ & $\begin{array}{c}\text { A equipe envolvida nos estudos preliminares para a } \\
\text { implantação dos PNMs Itaim, Jaceguava, Bororé e Varginha, } \\
\text { bem como o gestor da APABC, na ocasião, buscaram } \\
\text { envolver e ouvir lideranças locais, a sociedade civil } \\
\text { organizada e os conselheiros da APABC. }\end{array}$ \\
\hline & $\begin{array}{l}\text { Equidade na gestão de unidades } \\
\text { de conservação }\end{array}$ & $\begin{array}{l}\text { São encontradas amplas dificuldades para que o poder } \\
\text { público e, algumas vezes, também, a sociedade civil, efetive } \\
\text { o que é deliberado no conselho gestor da APABC. }\end{array}$ & $\begin{array}{l}\text { Campo fértil, porém frágil, semeado pelos gestores que } \\
\text { passaram pela APABC que empenharam esforços em } \\
\text { promover a equidade na gestão da UC. }\end{array}$ \\
\hline
\end{tabular}

Fonte: Autora. 2015. 
Este quadro, na medida em que destaca aspectos mais ressoantes, auxilia a situar o conselho gestor da APA Bororé-Colônia na "boa" governança de unidades de conservação. As cores atribuídas, entretanto, não devem ser compreendidas como estanques, tão pouco hierarquizam os resultados, elas apenas auxiliam a tentar implicar alguma medida, ainda que subjetiva, aos aspectos destacados. Por isso não devem ser compreendidas como uma escala matemática, cartesiana e exata. Da mesma forma, os resultados apontados em cada categoria não devem ser entendidos como imutáveis, eles se relacionam com os resultados dos demais critérios, e, por isso que, por mais que tenha se buscado apresentar novas observações ao longo de cada critério, é possível que algumas ideias tenham sido sutilmente reapresentadas.

A sociedade civil ligada a APA Bororé-Colônia passa por dificuldades de representação e legitimidade, bem como de renovação das lideranças, e dedica efetivamente pouco tempo para a vida política, para participar de assuntos relacionados à gestão ambiental pública. De certo o enfrentamento dessa realidade perpassa pela inclusão da educação política nas diversas instâncias de participação, como as escolas, unidades de conservação, igrejas, clubes, entre outras. Difícil enxergar outro caminho que não passe pela alternativa de que pelo menos os adultos de amanhã tenham conhecimento dos instrumentos e ferramentas existentes para participarem da gestão pública, incluindo nesse contexto a gestão ambiental, estejam sensíveis a esta questão e tenham aprendido a participar participando. A sociedade civil precisa ampliar sua capacidade política e de pressão, aumentar sua capacidade de raciocínio, deter maiores habilidades em construir argumentação para o diálogo, compreender um pouco mais das complexidades do mundo contemporâneo, conseguir cobrar efetivamente o poder público, entender e perceber as relações que incidem sobre o território e conseguir organizar os interesses daqueles cidadãos que eles representam.

Ao olhar para o poder publico há outros tipos de preocupações. Todo o arcabouço legal já traz suas atribuições, mas ele não a executa com a qualidade, a competência e a responsabilidade que a sociedade civil gostaria e merece. $O$ poder público tem demonstrado uma qualidade muito baixa de representação e participação no conselho gestor da APA Bororé-Colônia, comprometendo de maneira significativa a potencialidade do colegiado. Também tem sido ineficiente em executar o que é deliberado no conselho. Os governantes 
precisam ser sensibilizados para a questão da representação no conselho gestor da APABC; seus representantes precisam qualificar a participação, compreender o que colegiado representa, deve haver troca entre a instituição representada e o conselho, em um fluxo contínuo de qualidade dos assuntos tratados e de representatividade de seus membros. $\mathrm{O}$ poder público tem amplas responsabilidades e the cabe responder as demandas do conselho gestor da APABC. Ademais, o governo precisa assumir efetivamente as unidades de conservação municipais da zona sul de São Paulo, provendo-as com orçamento financeiro adequado e recursos humanos em número suficiente para sua gestão.

Como ponto de partida, parte das dificuldades enfrentadas pelo poder público e pela sociedade civil na busca por uma "boa" governança do conselho gestor da APA BororéColônia, no âmbito da Secretaria do Verde e do Meio Ambiente, podem ser objeto de atuação do programa de educação ambiental permanente previsto para acompanhar a gestão da unidade de conservação e de seu conselho. Uma abordagem crítica e um viés libertário, com uma concepção de outro modelo social, aquele que permite o enfrentamento contra-hegemônico da realidade (LOUREIRO; CUNHA, 2008), podem auxiliar o conselho gestor da $A P A B C$ no delineamento de uma estratégia para melhorar a governança no colegiado.

Ao que parece, é necessário se pensar formas de maior interface tanto do poder público quanto da sociedade civil na gestão ambiental pública; pensar em estratégias que possam ser adotadas para aumentar as condições de participação da sociedade civil e do poder público no colegiado tendo em vista uma relação de representatividade qualitativa entre representantes e representados. Ademais, o conselho gestor da APA Bororé-Colônia precisa amadurecer enquanto agente político para poder ampliar seus olhares e poder de atuação para além do colegiado, de modo que consiga encontrar novos caminhos para a concretização das suas demandas. Inovação, criatividade, compromisso, bem como a elevação dessa pauta para as agendas governamentais parecem ser necessárias nessa empreitada.

Embora enfrente grandes desafios, os resultados apontaram aspectos muito positivos sobre o conselho gestor da APA Bororé-Colônia. O colegiado é um agente político que atua como espaço de ensino aprendizagem, na medida em que permite que os conselheiros compreendam melhor a concepção dos outros atores sobre os problemas socioambientais, 
aprofundem seus conhecimentos, ampliem caminhos de diálogo, estabeleçam laços de confiança e cooperação na busca por soluções que sejam as mais adequadas naquela conjuntura para todas as partes envolvidas, instrumentalizem a sociedade e a mídia com informações que oportunizem influenciar na gestão ambiental pública.

O conselho gestor da APA Bororé-Colônia permitiu a articulação de uma rede, cujo objetivo comum é a existência da unidade de conservação. Neste sentido, o colegiado possui potencial como espaço aglutinador de pessoas comprometidas com a causa da APABC ou cidadãos que estejam buscando outras formas de vidas condizentes com as práticas fomentadas pela unidade de conservação, permitindo que essas pessoas se conheçam e, quiçá, unam esforços.

O conselho gestor da APA Bororé-Colônia também é um espaço que, na medida em que permite que o gestor (poder público) se relacione e discuta as ações a partir das figuras dos conselheiros, acaba por implicar à gestão um caráter personificado, é como se as instituições, órgãos e entidades passassem a ter rostos. O mesmo acontece na sociedade civil, não se trata mais dos moradores do bairro Chácara do Santo Amaro, se trata do Sr. Paixão e dos seus vizinhos, não se trata mais dos agricultores, se trata da Valéria e dos seus colegas de arado. 


\section{CONSIDERAÇÕES FINAIS}

As APA abrangem cerca de 4,57\% do território brasileiro (BRASIL, 2011), sendo uma categoria de unidade de conservação onde incidem complexas relações sociais, econômicas e políticas, além de diferentes relações com o ambiente natural. Sem dúvida merecem a atenção da comunidade acadêmica e do enriquecimento técnico científico que a universidade pode lhes prover.

As evidências empíricas coletadas ao longo do percurso (método) que guiou este estudo evidenciaram que o conselho gestor da APA Bororé-Colônia é um colegiado que permite a interação entre o poder público e as diversas organizações sociais que se relacionam com a $A P A B C$, incluindo representantes das camadas que foram historicamente alijadas das tomadas de decisão. O fórum enfrenta dificuldades nessa interação e também na tomada de decisões tendo em vista o bom exercício do poder para o cumprimento responsável dos objetivos da unidade de conservação e para a promoção da participação social na gestão ambiental pública, o que indica que possui um longo caminho a seguir. Porém, é um agente político; embora precise ampliar seu capital social, também possui grande potencial como espaço de ensino-aprendizagem; permite que os atores sociais dialoguem sobre assuntos ainda não conversados e que sejam construídas coletivamente alternativas que contem com o comprometimento de todos os conselheiros.

O referencial teórico dos princípios e critérios de "boa" governança propostos por Graham, Amos e Plumptre (2003) durante o V Congresso Mundial de Parques, utilizado como foco central da análise desta dissertação, embora tenha sido fundamental para responder ao objetivo proposto neste estudo precisou receber o suporte dos demais referenciais teóricos para ser operacionalizado, caso contrário teria uma abordagem rasa. Constatou-se, também, que alguns critérios são complexos e demandam uma análise mais longa para serem compreendidos profundamente, enquanto outros não têm aderência a realidade da unidade de conservação estudada e quiçá as unidades de conservação brasileiras.

Um estudo futuro poderia tropicalizar os princípios e critérios de "boa" governança na gestão das unidades de conservação (GRAHAM; AMOS; PLUMPTRE, 2003) propondo 
adaptações nos critérios de análise e produzindo indicadores que permitam acompanhar a evolução da governança em conselhos gestores de unidade de conservação do Brasil. Graham, Amos e Plumptre (2003) trazem em seu repertório o modelo de gestão de áreas protegidas que tem sido adotado no Canadá, diferente do modelo brasileiro, e os autores também tem como referencial os processos participativos na gestão pública que ocorreram em seu país, diferentes dos nossos.

Com o intuito de efetivar uma contribuição teórico-metodológica para o tema propõe-se a observação dos aspectos listados a seguir quando da realização de estudos que busquem observar, compreender e/ou qualificar a participação em conselhos gestores de unidades de conservação.

A- Elaboração da agenda: Quem / qual instituição propôs os assuntos da pauta? Quem / quais instituições contribuíram na condução dos assuntos em pauta na reunião? Esses números têm aumentando? São perguntas que merecem atenção quando se reflete sobre o maior envolvimento dos conselheiros na apropriação do espaço do conselho. A reunião não deve ser uma prestação de contas por parte do gestor, tão pouco um encontro para a divulgação de informativos. É um espaço para se definir quais são os assuntos prioritários daquele colegiado, quais são suas estratégias de enfrentamento, acompanhamento e avaliação, quais conselheiros estão envolvidos e suas responsabilidades, como se dá a transparência e o controle coletivo das iniciativas desenvolvidas. A definição de um problema, a priorização de um assunto, são construções sociais e demandam reconhecimento por parte dos envolvidos. $O$ status que um assunto tem quando está inserido dentro da agenda do conselho é um aspecto importante. Observar em que medida os conselheiros tem se apropriado desta abordagem pode refletir em um indicativo da participação no conselho.

B- Atuação das Câmaras Técnicas e Grupos de Trabalho: Como está a dinâmica das Câmaras Técnicas e Grupos de Trabalho quanto ao número de reuniões, a agenda de trabalho, as ações e projetos em andamento, a avaliação das atividades desempenhadas, a prestação de contas das atividades e a interlocução com outros setores e fóruns externos ao conselho? A resposta a essa pergunta pode esclarecer se o que realmente tem valor está ativo. Essas estruturas podem 
permitir maior descentralização do poder refletindo em mais controle coletivo e participação dos conselheiros na condução de temas específicos, além de terem o potencial de dialogarem com espaços e instituições externas ao conselho.

C- Presença de mais membros da sociedade civil nas reuniões: Além dos conselheiros as reuniões têm contado com a presença de outros membros da sociedade civil? A resposta para essa pergunta pode trazer indicativos de como a sociedade civil tem enxergado o potencial do conselho em encaminhar assuntos que lhe interessam e que também dizem respeito ao colegiado. Se um membro da sociedade civil que não tem cadeira no conselho comparece a reunião é porque ele tem algum interesse que o motiva a estar ali, não é por mera obrigação. Na atual conjuntura, na qual as pessoas têm pouco tempo para dedicar à vida política, a presença de cidadãos em conselhos gestores de unidades de conservação pode demonstrar seu interesse em participar mais ativamente da gestão ambiental pública e pode ser um indicativo para se observar a participação naquele colegiado. Se aprende a participar participando, então estar presente em um fórum participativo é premissa para poder participar.

D- Interessados em pleitear vagas no conselho: Há mais representantes da sociedade civil interessados em pleitear vagas no conselho? Em caso afirmativo, qual setor representam e o que os motiva? São perguntas interessantes de se responder quando se reflete sobre a credibilidade do conselho junto à sociedade civil. Seguindo a mesma lógica que o tópico anterior, a presença de mais interessados em pleitear as vagas no conselho pode ser um indicativo para se observar a participação.

E- Número de reuniões: Como está a freqüência das reuniões? O número tem variado, por quê? São perguntas que merecem atenção quando se reflete sobre a animação do conselho. Em um primeiro momento de desenvolvimento dos conselhos, onde a participação ainda é embrionária, e não se vislumbra uma relação de eficiência entre recursos obtidos (resultados) e recursos empregados (tempo), uma crescente no número de reuniões e em sua freqüência pode trazer indicativos de como está a vivacidade do conselho. Não é uma relação cartesiana, 
na qual mais reuniões refletiriam em maior participação. Mas é um aspecto a ser observado para analisar o ânimo do conselho e assim ter indícios sobre a qualidade da participação dos conselheiros. Se o conselho tem assuntos a tratar e os conselheiros, porque Ihe dão a devida importância, conseguem the dedicar mais tempo realizando mais reuniões, pode ser um indicativo para se observar a participação naquele fórum.

F- Projetos e/ou ações encampadas pelo conselho bem como acordos e/ou parcerias firmadas: Há projetos, ações, acordos ou parcerias que foram encampados ou firmados pelo conselho? Em caso afirmativo em qual situação se encontram? Houve aumento nesse número? As respostas para essas perguntas podem contribuir na reflexão sobre o entendimento dos conselheiros acerca do papel que o conselho ocupa, aspecto importante que reflete na compreensão e nas expectativas que cada cidadão possui sobre sua participação naquele fórum. O conselho é um agente político, que ocupa um espaço legitimado dentro da sociedade brasileira e da sua gestão ambiental pública. A compreensão dos conselheiros de que o conselho pode transpor o espaço de sua reunião ordinária e encampar projetos e ações, ou firmar acordos e parcerias pode ser um indicativo de maturidade quando se observa a participação nos colegiados.

\section{G- Participações / representações do conselho em fóruns e espaços políticos} externos: Há participações / representações do conselho em fóruns e/ou espaços políticos que Ihes são externos? Em caso afirmativo, como têm se desenrolado (dinâmica, devolutiva para os conselheiros), quais são os resultados alcançados quais os desafios enfrentados e quais são as expectativas futuras? De modo complementar ao item anterior, as respostas a essas perguntas podem contribuir para compreender o entendimento que os conselheiros possuem sobre o papel que o conselho ocupa, e por conseqüência nas expectativas que debruçam acerca de sua participação naquele fórum. Pode estar havendo um incremento na participação dos conselheiros na medida em que eles compreendem que é importante o conselho estar presente em outros espaços políticos para levar suas pautas, demandas e para articular com outros atores. 
H- Comunicação (canais/meios) entre os conselheiros e entre o conselho e os agentes externos: Como estão a transparência, o acesso às relações e aos processos relativos à gestão da $A P A B C$ entre os conselheiros e entre o conselho $e$ a sociedade? É uma pergunta que merece atenção quando se reflete sobre a participação em conselhos. O espaço do conselho tem relação direta com o exercício da cidadania e da educação, e a comunicação é premissa para que o cidadão comum tenha acesso a informações que lhe permitam se colocar como sujeito em um contexto de participação na gestão pública. Uma comunicação de qualidade, primeiro entre os representantes dos membros do conselho, e depois entre o conselho e os agentes externos é o ponto de partida para que os cidadãos ampliem sua capacidade de participação, acessando informações mais relevantes que lhe permitam agir com poder regulatório na gestão ambiental pública.

I- Incrementos estruturais (Secretaria Executiva, Representante da sociedade civil): Os incrementos estruturais previstos no regimento interno do conselho (secretaria executiva, representante da sociedade civil, entre outros) estão atuantes? Em caso afirmativo como tem se dado essa atuação? Avalie. As respostas a essas perguntas podem trazer indicativos do quanto que o conselho se apropriou da modernidade trazida pelos dispositivos legais tendo em vista o fomento a participação dos conselheiros. De nada adianta existirem esses incrementos estruturais que possibilitam a distribuição do poder se eles não são apropriados pelos conselheiros como tal. A apropriação ativa desses incrementos estruturais por parte dos conselheiros pode ser um aspecto que demonstre a qualificação da participação no colegiado.

J- Devolutivas de órgãos/instituições públicas para o conselho: $O$ conselho tem recebido devolutivas de órgãos e instituições públicas (representadas e nãorepresentadas no colegiado) que por ele foram de alguma forma acionadas? A resposta a essa pergunta pode trazer indicativos de como o conselho está atuando em sua capacidade de articulação com o poder público para atender suas demandas. Em uma unidade de conservação com as características de uma Área de Proteção Ambiental a questão da articulação entre os entes do poder público é premissa para se obter sucesso na gestão. Compreender os avanços e 
dificuldades neste aspecto, bem como situar o olhar sobre o status do conselho frente ao poder público pode trazer subsídio a compreensão de nuances da participação no colegiado.

K- Dinâmica das reuniões (horário, local e transporte): Onde ocorrem as reuniões? Qual horário? Qual freqüencia? Como os conselheiros fazem para acessar esse local? Analisar estas respostas pode trazer subsídios para compreender as condições de equidade de acesso às reuniões que são o ponto de partida para possibilitar a participação. Há de se compreender que alguns conselheiros têm mais dificuldade de acesso e precisam de mais apoio para poderem ter as mesmas condições que os outros pares têm para comparecerem nas reuniões. Os conselheiros do poder público, e também aqueles da sociedade civil que representam instituições na qual ocupam um cargo remunerado, estão em horário de expediente quando vão às reuniões, além de contarem com subsídio de transporte. O mesmo não ocorre com membros de Associações de Bairro, de Pescadores, Agricultores. Estes, na maioria das vezes, estão perdendo um dia útil de trabalho, além de não contarem, em geral, com apoio algum para se deslocarem até as reuniões. Analisar esse cenário e o subsídio que o poder público tem oferecido para esses cidadãos é um aspecto que pode contribuir na análise da participação em conselhos.

\section{L- Ferramentas e técnicas de participação e mediação de conflitos incorporadas:} Quais são as estratégias, técnicas e ferramentas adotadas ao longo das reuniões para fomentar a participação e realizar a mediação de conflitos? A resposta dessa pergunta pode trazer subsídios para a reflexão acerca de como os trabalhos no conselho tem sido conduzidos por parte do órgão gestor para fomentar a participação. É reconhecido que metodologias participativas agregam na dinâmica das reuniões permitindo que se compartilhem conhecimentos e experiências entre os participantes, facilitando o encaminhamento de algumas questões por meio da tomada de decisões coletivas e permitindo que a reunião seja mais propositiva alcançando seus objetivos. Há ferramentas que podem ajudar aqueles que conduzem as reuniões a mediar os conflitos de modo participativo, da mesma forma há também ferramentas que podem ajudar a 
estimular a participação daqueles que já largam com mais dificuldade de participar - seja porque têm acesso a poucas informações, ou informações de baixa qualidade, seja porque têm mais dificuldades em expor as idéias que defendem. Analisar o quanto elas têm sido incorporadas podem contribuir na análise da participação nos conselhos.

M- Inovação / novos caminhos alcançados / galgados para problemas corriqueiros: O conselho tem buscado e galgado novos caminhos para seus problemas corriqueiros? A resposta a essa pergunta pode trazer aspectos que subsidiem a reflexão sobre os avanços da participação em conselhos. Em um cenário no qual o desenvolvimento da participação em conselhos é tão incipiente a inovação parece ser uma premissa para aqueles que desejam dias diferentes e melhores. Analisar o quanto o conselho tem inovado pode contribuir na análise da participação nesses colegiados.

Esta descrição é apenas introdutória e almeja registrar aspectos mais importantes percebidos ao longo desta pesquisa, bem como estimular estudos futuros provendo-os de alguma idéia do traçado que pode ter esta trilha pelos princípios e critérios tropicais de governança em conselhos gestores de unidades de conservação. Estes estudos devem levar também outros aspectos em consideração que aqui não foram contemplados, como a relação entre o gestor da unidade de conservação e a instituição gestora da UC, bem como aspectos dos governos e intervenções causadas pelas mudanças governamentais na gestão pública.

A governança em unidades de conservação continua sendo um tema extremamente relevante e longe de ser esgotado. No mais recente (VI) Congresso Mundial de Parques, realizado em 2014 pela International Union for Conservation of Nature (IUCN), em Sidney, foi apontada como prioritária a necessidade da comunidade que atua na conservação da natureza compreender melhor e realizar mais ações relacionadas à governança para a conservação da natureza; bem como avançar com a "fronteira da governança" para abranger ações mais urgentes que estão na agenda da humanidade, como libertar-se dos modelos de desenvolvimento baseados no crescimento e substituí-los por economias e sociedades mais sustentáveis, equitativas e satisfatórias (IUCN, 2014). Na governança das 
unidades de conservação há um longo caminho a percorrer que merece a atenção da comunidade acadêmica. 


\section{REFERÊNCIAS BIBLIOGRÁFICAS 92}

ABERS, R. N.; KECK, M. E. Representando a diversidade: Estado, sociedade e "relações fecundas" nos conselhos gestores. 2008. In: Caderno CRH, Salvador, v.21, n.52, p.99-112. Jan./Abr. 2008.

ARNSTEIN, S. R. Uma escada de participação cidadã. Revista da Associação Brasileira de Promoção da Participação. Porto Alegre, ano 2, n. 2, jan. 2002.

BERNARDELLI JUNIOR, J. M. Conflitos socioambientais urbanos na APA Bororé-Colônia: o caso do Parque Natural Municipal do Itaim. 2013. Dissertação (Mestrado Profissional em Gestão Ambiental e Sustentabilidade) - Universidade Nove de Julho, São Paulo, 2013.

BORELLI, M. Mananciais urbanos e sustentabilidade na Grande São Paulo. In: XIV Encontro Nacional da ANPUR, 2011, Rio de Janeiro. Disponível em: < file://C:/Documents\%20and\%20Settings/julianafc/Meus\%20documentos/Downloads/37007371-1-SM.pdf> Acesso em: 03 de outubro de 2014.

BORDENAVE, J. D. O que é participação? São Paulo: Ed. Brasiliense, 1985.

BRASIL. Decreto no 5.758, de 13 de abril de 2006. Institui o Plano Estratégico Nacional de Áreas Protegidas - PNAP, seus princípios, diretrizes, objetivos e estratégias, e dá outras providências. Diário Oficial da União, Brasília, DF, 17 abril 2006.

BRASIL. Decreto no 4.340 de 22 de agosto de 2002. Regulamenta a Lei $n$ o 9.985/2000 que dispõe sobre o Sistema Nacional de Unidades de Conservação. Diário Oficial da União, Brasília, DF, 23 agosto 2002.

BRASIL. Lei no 6.938, de 31 de agosto de 1981. Dispõe sobre a Política Nacional do Meio Ambiente, seus fins e mecanismos de formulação e aplicação, e dá outras providências. Diário Oficial da União, Brasília, DF, 02 setembro 1981.

BRASIL. Lei no 9.985, de 18 de julho de 2000. Regulamenta o art. 225, § 10, incisos I, II, III e VII da Constituição Federal, institui o Sistema Nacional de Unidades de conservação da Natureza e dá outras providências. Diário Oficial da União, Brasília, DF, 19 julho 2000.

92 De acordo com a Associação Brasileira de Normas Técnicas. NBR 6023. 
BRASIL. Ministério do Meio Ambiente. Sistema Nacional de Unidades de Conservação da Natureza, $2011 . \quad$ Disponível em: http://www.mma.gov.br/estruturas/240/ publicacao/240 publicacao05072011052536.pdf Acessado em: 11 abril 2015.

BRASIL. Resolução do Conselho Nacional de Saúde no466, de 12 de dezembro de 2012. Aprova diretrizes e normas regulamentadoras de pesquisas envolvendo seres humanos. Diário Oficial da União, Brasília, DF, 13 de junho de 2013.

CARNEIRO, C. B. L. Conselho de políticas publicas: desafios para sua institucionalização. Revista de Administração Pública, v. 36, n. 2, p. 277-292, 2002.

COMISSÃO SOBRE GOVERNANÇA GLOBAL. Nossa Comunidade Global. Rio de Janeiro: Editora Fundação Getúlio Vargas, 1996.

COZZOLINO, L. F. Unidades de Conservação e os processos de Governança Local: o caso da APA do Sana (Macaé-RJ). 2005. Dissertação (Mestrado em Psicologia de Comunidades e Ecologia Social) - Universidade Federal do Rio de Janeiro, Rio de Janeiro, 2005.

COZZOLINO, F.; IRVING, M. de A. Gestão em Unidades de Conservação: um caminho teórico e metodológico possível a partir da ótica da governança na APA do Sana (Macaé-RJ). In: IRVING, M. de A. (org.). Áreas protegidas e inclusão social: construindo novos significados. Rio de Janeiro: Fundação Bio-Rio, Aquarius, 2006. p. 185-200.

CÂMARA MUNICIPAL DE SÃO PAULO - CMSP. Processo Legislativo do Projeto de Lei 01384/2004 do Executivo - Marta Suplicy. Processo digitalizado código 00000020147-26. 16.nov. 2014

COELHO, V. S. P. Conselhos de Saúde Enquanto Instituições Políticas: o que está faltando? In COELHO, V. S. P. e NOBRE, M. (orgs.). Participação e Deliberação: Teoria Democrática e Experiências Institucionais no Brasil Contemporâneo. São Paulo, Ed. 34, 2004, p. 255 - 269.

CONSELHO ESTADUAL DE MEIO AMBIENTE. Deliberação no 21, de 17 de agosto de 2004. Delibera sobre a responsabilidade da Comissão Especial de Avaliação de Impacto Ambiental a tarefa da analisar o documento "Avaliação Ambiental Estratégica do Rodoanel". Diário Oficial do Estado de São Paulo, São Paulo, 20 de agosto de 2004.

CONSELHO NACIONAL DE MEIO AMBIENTE - IBAMA. Resolução no 01 de 23 de janeiro de 1986. Resolve sobre a necessidade de se estabelecerem as definições, as responsabilidades, 
os critérios básicos e as diretrizes gerais para uso e implementação da Avaliação de Impacto Ambiental como um dos instrumentos da Política Nacional de Meio Ambiente. Diário Oficial da União, 17 de fevereiro de 1986.

CONSELHO NACIONAL DE MEIO AMBIENTE - IBAMA. Resolução no 237 de 19 de dezembro de 1997. Resolve sobre questões relacionadas ao Licenciamento Ambiental. Disponível em: < http://www.mma.gov.br/port/conama/res/res97/res23797.html>. Acesso: 26 abril 2014.

DEMO, P. Participação é conquista: noções de política social participativa. São Paulo, Cortez: Autores Associados, 1988.

DIEGUES, A. C. Etnoconservação da natureza: enfoques alternativos. In: Diegues, A. C. (org.). Etnoconservação: novos rumos para a proteção da natureza nos trópicos. São Paulo: Ed. Hucitec, 2000.

DIEGUES, A. C. O mito moderno da natureza intocada. 6a edição revista e ampliada. São Paulo: Hucitec NUPAUB, 2001.

DUDLEY, N. (editor). Guideline for Applying Protected Area Management Categories. Gland, Switzerland: IUCN, 2008.

FARIA, H. H. Elaboración de un procedimiento para medir la efectividad de manejo de áreas silvestres protegidas y su aplicación en dos áreas protegidas de Costa Rica, América Central. Tesis de Mg.Sc. Turrialba, Costa Rica: CATIE, 1993.

FARIA, H. H. Efectividad del Manejo de Áreas Protegidas del Estado de São Paulo, Brasil. In: 2o Congreso Latinoamericano de Parques Nacionales y Otras Áreas Protegidas, 2007, San Carlos de Bariloche. Anais 2o Congreso Latinoamericano de Parques Nacionales y Otras Áreas Protegidas. Gland: IUCN, 2007. v. 3.

FERNANDES, B. M. Movimentos socioterritoriais e movimentos socioespaciais. Revista Del Observatorio Social de America Latina, Buenos Aires, v.6, edição 16, p. 273-283, 2005. Editora Clacso

FERREIRA, L. C. A floresta intransitiva: conflitos e negociações na mata atlântica, SP. Tese (Doutorado em Ciências Sociais) - UNICAMP, Campinas, 1996.

FREY, K. Governança Urbana e Participação Pública. In: ANPAD anais. Disponível em: < http://www.anpad.org.br/periodicos/arq pdf/a 629.pdf>. Acesso em: 26 abril 2014. 
FUNDAÇÃO FLORESTAL. Unidades de Conservação: Parques Estaduais. Disponível em: < http://fflorestal.sp.gov.br/unidades-de-conservacao/parques-estaduais/parquesestaduais/>. Acesso em: 06 outubro 2014a.

FUNDAÇÃO FLORESTAL. Parque Estadual da Serra do Mar: Núcleo Curucutu. Disponível em: <http://www.ambiente.sp.gov.br/parque-serra-do-mar-nucleo-curucutu/sobre-o-parque/>. Acesso em: 06 outubro 2014b.

GALANTE, M. L. et. al. Roteiro Metodológico de Planejamento. Parque Nacional, Reserva Biológica, Estação Ecológica. Brasília: IBAMA, 2002.

GRAHAM, J.; AMOS, B.; PLUMPTRE, T. Governance Principles for Protected Areas in the 21st Century. Durban, UICN. 2003.

GOHN, M. da G. Conselhos gestores e participação sociopolítica. São Paulo: Cortez, 2003.

GONÇALVES, D. L. O conceito de desenvolvimento sustentável na gestão pública: um estudo sobre a APA Municipal Bororé-Colônia. 2010. Trabalho de graduação individual (Graduação - Bacharel) - Departamento de Geografia, Universidade de São Paulo, São Paulo, 2010.

GONÇALVES, D. L. Monitoramento de Áreas de Proteção Ambiental através de indicadores de sustentabilidade. 2014. Dissertação (Mestrado em Geografia Física) - Departamento de Geografia, Universidade de São Paulo, São Paulo, 2014.

GOVERNO DO ESTADO DE SÃO PAULO. Rodoanel Mário Covas. Disponível em: http://www.saopaulo.sp.gov.br/rodoanel. Acesso em: 15 junho 2015.

HAESBAERT, R. O mito da desterritorialização: do "fim dos territórios" a multiterritorialidade. Rio de Janeiro: Bertrand Brasil, 2004.

INSTITUTO BRASILEIRO DE MEIO AMBIENTE E DOS RECURSOS NATURAIS RENOVÁVEIS. Efetividade de gestão das Unidades de Conservação federais do Brasil. Ibama, WWF Brasil - Brasília: Ibama, 2007.

INSTITUTO CHICO MENDES DE CONSERVAÇÃO DA BIODIVERSIDADE - ICMBIO (Ministério do Meio Ambiente). Conselho de unidades de conservação federais: um guia para gestores e conselheiros. Brasília, 2014. 
INSTITUTO DE PESQUISA ECONÔMICA APLICADA - IPEA. Brasil: o Estado de uma Nação. Brasília: Ministério do Planejamento, Orçamento e Gestão/IPEA, 2005.

INSTITUTO SOCIOAMBIENTAL - ISA. Seminário Billings 2002: avaliação e identificação de áreas e ações prioritárias para a conservação, recuperação e uso sustentável da Bacia Hidrográfica da Billings. São Paulo: Instituto Socioambiental, 2003.

INSTITUTO SOCIOAMBIENTAL - ISA; SECRETARIA DO VERDE E DO MEIO AMBIENTE - SVMA. Projeto Grupo de Estudo sobre o Rodoanel - Relatório Final. Subsídios técnicos para a elaboração do parecer sobre Impactos Ambientais e Medidas Mitigadoras e Compensatórias do Trecho Sul do Rodoanel Mário Covas. São Paulo, 2005.

INSTITUTO CHICO MENDES DE CONSERVAÇÃO DA BIODIVERSIDADE - ICMBIO. Os 10 Parques Nacionais mais visitados de 2010 a 2012. Disponível em: < http://www.icmbio.gov.br/portal/images/stories/o-que-fazemos/10 visitados.pdf>.

Acesso em: 01 maio 2014.

IBASE - INSTITUTO BRASILEIRO DE ANÁLISES SOCIAIS E ECONÔMICAS. Gestão participativa em Unidades de Conservação. Rio de Janeiro, 2006. Disponível em: < http://www.ibase.br/userimages/ap ibase gestao 01c.pdf>. Acesso em: 03 março 2014.

INTERNATION UNION FOR CONSERVATION OF NATURE - IUCN. Red list of Threatened Species. Switzerland: IUCN, 2009.

INTERNATION UNION FOR CONSERVATION OF NATURE - IUCN. Una estrategia de enfoques innovadores y recomendaciones para mejorar la diversidad, calidad y vitalidad de la gobernanza durante la próxima década. Sidney, IUCN, 2014.

IRVING, M. de A; COZZOLINO, F.; FRAGELLI, C.; SANCHO, A. Construção de governança democrática: Interpretando a gestão de parques nacionais no Brasil. In: IRVING, M. de $A$. (org.). Áreas protegidas e inclusão social: construindo novos significados. Rio de Janeiro: Fundação Bio-Rio, Aquarius, 2006. p. 41-75.

JACOBI, P. R. A gestão participativa de bacias hidrográficas no Brasil e os desafios do fortalecimento de espaços públicos colegiados. In: COELHO, V. S. P; NOBRE, M. (Orgs). Participação e deliberação: teoria democrática e experiências institucionais no Brasil contemporâneo. São Paulo: Ed. 34, 2004. 
KINGDON, J. Como chega a hora de uma ideia? In: SARAIVA, E.; FERRAREZI, E. (org.). Políticas Públicas: Coletânea - Volume 1. Brasília: ENAP, 2006.

KLIJN, E. H. Redes de Políticas Públicas: uma visión general. Diponível em: revistaredes.rediris.es/webredes/textos/Complex.pdf. 1998.

LABORATÓRIO DE HABITAÇÃO E ASSENTAMENTOS HUMANOS DA FACULDADE DE ARQUITETURA E URBANISMO DA UNIVERSIDADE DE SÃO PAULO - LabHab FAUUSP. Impactos urbanísticos do Trecho Oeste do Rodoanel Mario Covas: estudo preliminar. São Paulo, 2005.

LAYRARGÜES, P. P. Educação para a gestão ambiental: a cidadania no enfrentamento político dos conflitos socioambientais. In: LOUREIRO, C. F.; LAYRARGÜES, P.P.; CASTRO, R. S. (orgs.) Sociedade e meio ambiente: a educação ambiental em debate. São Paulo: Cortez, 2000. p. 87-155.

LOUREIRO, C. F. B.; AZAZIEL, M.; FRANCA, N. Educação ambiental e Gestão Participativa em Unidades de Conservação. Rio de Janeiro: IBASE/IBAMA. 2003

LOUREIRO, C. F. B. Complexidade e dialética: contribuições à práxis política e emancipatória em educação ambiental. Educação \& Sociedade, Campinas, vol. 27, n. 94, p. 131-152, jan./abr. 2006.

LOUREIRO, C. F. B.; CUNHA, C. C. Educação ambiental e gestão participativa de unidades de conservação: elementos para se pensar a sustentabilidade democrática. Revista Ambiente e Sociedade. Campinas. V.XI, no2. P. 237-253. 2008.

LOWI, T. J. Four Systems of Policy, Politics and Choice. Public Administration Review. American Society for Public Administration. Vol. 32, no 4, 1972.

LÜDKE, M.; ANDRÉ, M.E.D.A. Pesquisa em educação: abordagens qualitativas. São Paulo: EPU. 1986.

MACIEL, T. B. Da sustentabilidade à sustentabilidade do ser: por um desenvolvimento humano durável. In: D'AVILLA NETO, M. I.; PEDRO, R. M. I. R. (orgs.) Tecendo o desenvolvimento: saberes, gênero, ecologia social. (Coleção EICOS - Estudos Interdisciplinares de Comunidades de Ecologia Social) Rio de Janeiro: MAUAD: Bapera Editora, 2003. 
MASSARDIER, G. Redes de políticas públicas. In : SARAIVA, E.; FERRAREZI, E. Políticas Públicas: Coletânea - Volume 2. Brasília: ENAP, 2006

MEDEIROS, R.; IRVING, M. de A.; GARAY, I. Áreas protegidas no Brasil: interpretando o contexto histórico para pensar a inclusão social. In: IRVING, M. de A. (org.). Áreas protegidas e inclusão social: construindo novos significados. Rio de Janeiro: Fundação BioRio, Aquarius, 2006. p. 15-40.

MEYERS, M.; VORSANGER, S. Burocratas de nível de rua e a implementação de políticas públicas. In: PETERS, Guy e PIERRE, Jon (org.). Administração pública: coletânea. São Paulo: Editora da UNESP; Brasília: ENAP, 2010.

MINAYO, M. C. D. S. O desafio do conhecimento: pesquisa qualitativa em saúde. 10a Ed. São Paulo: Editora Hucitec, 2007.

MMA - MINISTÉRIO DO MEIO AMBIENTE. Gestão participativa do SNUC. Vários. Brasília: Ministério do Meio Ambiente, 2004.

PARAÍSO, L. B. Dilemas da participação na gestão de unidades de conservação: a experiência do projeto Doces Matas na RPPN Mata do Sossego. In.: ZHOURI, A.; LASCHEFSKI, K.; PEREIRA, D. B (org.). A insustentável leveza da política ambiental desenvolvimento e conflitos socioambientais. Belo Horizonte: Autêntica, 2005. p. 143-168.

PORTO, D. N. A metrópole e a natureza: representações, sociabilidade e mobilização na península do Bororé, na Billings. Tese (Doutorado) - Ciências Sociais, Pontifícia Universidade Católica, São Paulo, 2004.

PUTNAM, R. D. Comunidade e democracia: a experiência da Itália moderna. Rio de Janeiro: FGV, 1996.

PREFEITURA MUNICIPAL DE SÃO PAULO, 2012. Ecoturismo e agroecologia no extremo sul de São Paulo. Vários. São Paulo: Secretaria Municipal do Verde e do Meio Ambiente, 2012.

PREFEITURA MUNICIPAL DE SÃO PAULO, 2014a. Secretaria Municipal do Verde e do Meio Ambiente - APA Bororé-Colônia. Pesquisa geral na homepage. Disponível em: < http://www.prefeitura.sp.gov.br/cidade/secretarias/meio ambiente/unid de conservacao/ apa bororecolonia/index.php?p=41963>. Acesso: 08 maio 2015.

PREFEITURA MUNICIPAL DE SÃO PAULO, 2014b. Secretaria Municipal de Coordenação das Subprefeituras. Pesquisa geral na homepage. Disponível em: < 
http://www.prefeitura.sp.gov.br/cidade/secretarias/subprefeituras/subprefeituras/mapa/in dex.php?p=14894>. Acesso: 26 abril 2014.

PREFEITURA MUNICIPAL DE SÃO PAULO, 2014c. Plano de Gestão 2013 - 2015 do Conselho Gestor da Área de Proteção Ambiental Bororé-Colônia. São Paulo. Câmara Técnica de Planejamento e Gestão.

PREFEITURA MUNICIPAL DE SÃO PAULO, 2014d. Parque Natural Municipal Jaceguava. Pesquisa geral na homepage. Disponível em: < http://www.prefeitura.sp.gov.br/cidade/secretarias/meio ambiente/unid de conservacao/ index.php? $\mathrm{p}=42076>$. Acesso: 13 abril 2014

PREFEITURA MUNICIPAL DE SÃO PAULO, 2014e. Parque Natural Municipal Itaim. Pesquisa geral na homepage. Disponível em: http://www.prefeitura.sp.gov.br/cidade/secretarias/meio ambiente/unid de conservacao/ index.php?p=42075 >. Acesso: 13 abril 2014.

PREFEITURA MUNICIPAL DE SÃO PAULO, 2014f. Parque Natural Municipal Bororé. Pesquisa geral na homepage. Disponível em: < http://www.prefeitura.sp.gov.br/cidade/secretarias/meio ambiente/unid de conservacao/ index.php?p=42074>. Acesso: 13 abril 2014.

PREFEITURA MUNICIPAL DE SÃO PAULO, 2014g. Parque Natural Municipal Varginha. Pesquisa geral na homepage. Disponível em: < http://www.prefeitura.sp.gov.br/cidade/secretarias/meio ambiente/unid de conservacao/ index.php?p=42077>. Acesso: 13 abril 2014.

PREFEITURA MUNICIPAL DE SÃO PAULO, 2014h. Relatório Executivo 2014. Apresentação em PowerPoint disponibilizada pelo gestor da APA Bororé-Colônia.

PREFEITURA MUNICIPAL DE SÃO PAULO, 2015a. Guarapiranga Sustentável. Pesquisa geral na homepage. Disponível em: < http://appvps5.cloudapp.net/sigam3/Default.aspx?idPagina=7747>. Acesso: 25 abril 2015.

PREFEITURA MUNICIPAL DE SÃO PAULO, 2015b. Secretaria Municipal do Verde e do Meio Ambiente - APA Capivari Monos. Pesquisa geral na homepage. Disponível em: < http://www.prefeitura.sp.gov.br/cidade/secretarias/meio ambiente/unid de conservacao/ apa capivarimonos/index.php? $\mathrm{p}=41966$ >. Acesso: 08 maio 2015. 
QUINTAS, J. S. Pensando e praticando educação ambiental na gestão do meio ambiente. Brasília: IBAMA, 2000.

QUINTAS, J. S. Introdução a gestão ambiental pública. Brasília: IBAMA, 2005.

RAIMUNDO, S. Abordagem Geográfica nas Atividades de Lazer e Turismo. In: Beatriz Gelas Lages. (Org.). Lazer e Turismo: conceitos e reflexões. 1 ed. São Paulo: Plêiade, 2009, v. 1, p. 199-224.

RAIMUNDO, S. PACHECO, R.; MACHADO, J. T.; COSTA, B. M. da; ALVES, C. J.; SANTOS, G. L.; SOUZA, L. L. Relatório de atividades: Programa de Uso Público: Plano de Manejo Parques Municipais Rodoanel Trecho Sul. São Paulo: Cooperação Técnica Cientifica DERSA / Depto de Geografia FFLCH/USP, 2010.

RAFFESTIN, C. Por uma geografia do poder. São Paulo: Editora Ática S.A., 1993.

RADOLL, G. A criação do Parque Natural Municipal Itaim e sua potencialidade como catalisador de transformações socioambientais. Dissertação (Mestrado em Arquitetura) Faculdade de Arquitetura e Urbanismo, Universidade de São Paulo, São Paulo, 2014.

REITER, A. S.; ASCAR, F.; BAPTISTA, M.; BELLENZANI, M. L (org.). Ecoturismo e agrocecologia no extremo sul de São Paulo. São Paulo: Secretaria Municipal do Verde e do Meio Ambiente, 2012.

RICHARDSON. R. J. Pesquisa social: métodos e técnicas. São Paulo: Ed. Atlas, 1999.

RODRIGUES, E. A.; VICTOR, R. A. B. M.; PIRES, B. C. C. A Reserva da Biosfera do Cinturão Verde da Cidade de São Paulo como marco para a gestão integrada da cidade, seus serviços ambientais e o bem-estar humano. São Paulo em Perspectiva, São Paulo, v. 20, n. 2, p.71-89, abr./jun. 2006. SANTOS, 2003

SABESP. Sistema Cantareira garante abastecimento. Agência de notícias. Disponível em: $<$ http://www.sabesp.com.br/CalandraWeb/CalandraRedirect/?temp=4\&proj=AgenciaNoticia $\underline{s \& p u b=T \& d b=\& d o c i d=3 B 3851 C 287055 C 148325770600671 F D D}>$. Acesso em: 03 de outubro de 2014a.

SABESP. Situação

dos

Mananciais.

Disponível em: <http://www2.sabesp.com.br/mananciais/ >. Acesso em: 03 de outubro de 2014b. 
SANTILLI, J.; SANTILLI, M. Meio ambiente e democracia: participação social na gestão ambiental. In: LIMA, A. (org.). O direito para o Brasil socioambiental. Porto Alegre: Sergio Antônio Fábris Editor, 2002.

SANTOS, R. M. APA Bororé: Subsídios à implantação. 2003. Trabalho de graduação individual (Graduação - Bacharel) -Departamento de Geografia, Universidade de São Paulo, São Paulo, 2003.

SANTOS JUNIOR, O. A.; AZEVEDO, S.; RIBEIRO, L. C. Q. Democracia e Gestão local: a experiência dos Conselhos Municipais no Brasil. In: Governança democrática e poder local. Rio de Janeiro: Editora Revan, 2004.

SÃO PAULO (Cidade). Decreto no 52.972, de 14 de fevereiro de 2012. Cria e denomina o Parque Natural Municipal Bororé. Diário Oficial da Cidade de São Paulo, São Paulo, 15 de fevereiro de 2012.

SÃO PAULO (Cidade). Decreto no 52.973, de 14 de fevereiro de 2012. Cria e denomina o Parque Natural Municipal Varginha. Diário Oficial da Cidade de São Paulo, São Paulo, 15 de fevereiro de 2012.

SÃO PAULO (Cidade). Decreto no 52.974, de 14 de fevereiro de 2012. Cria e denomina o Parque Natural Municipal Jaceguava. Diário Oficial da Cidade de São Paulo, São Paulo, 15 de fevereiro de 2012.

SÃO PAULO (Cidade). Decreto no 53.227, de 20 de junho de 2012. Cria e denomina o Parque Natural Municipal Itaim. Diário Oficial da Cidade de São Paulo, São Paulo, 21 de junho de 2012.

SÃO PAULO (Cidade). Lei no 14.162, 24 de maio de 2006. Cria a unidade de conservação área de proteção ambiental municipal Bororé-Colônia. Diário Oficial da Cidade de São Paulo, São Paulo, 25 de maio 2006.

SÃO PAULO (Cidade). Regimento Interno do Conselho gestor da Área de Preservação Ambiental Bororé-Colônia de acordo com a Lei Municipal no 14.162, 24 de maio de 2006. Disponível em:

http://www.prefeitura.sp.gov.br/cidade/secretarias/upload/chamadas/reg interno apa bo rore colonia 1340652083.pdf>. Acesso em: 26 de abril 2014. 
SÃO PAULO (Estado). Decreto Estadual no 48.149/2003, de 09 de outubro de 2003. Dispõe sobre a criação e funcionamento dos Conselhos Gestores das Áreas de Proteção Ambiental APAs no Estado de São Paulo e dá providências correlatas. Diário Oficial do Estado de São Paulo, 10 de outubro de 2003.

SÃO PAULO (Estado). Lei Estadual no 13.579, de 13 de julho de 2009. Define a Área de Proteção e Recuperação aos Mananciais da Bacia Hidrográfica do Reservatório Blllings APRM-B. Diário Oficial do Estado de São Paulo, 14 de julho de 2009.

SEADE - Fundação Sistema Estadual de Análise de Dados. Perfil da Região Metropolitana de São Paulo. Disponível em: $<$ http://produtos.seade.gov.br/produtos/perfil regional/index.php>. Acesso em: 03 de outubro de 2014.

SECRETARIA DE ESTADO DE MEIO AMBIENTE - SMA (São Paulo). Relatório Ambiental Rodoanel Mário Covas. 2009. Disponível em: < http://www.ambiente.sp.gov.br/wpcontent/uploads/noticias/relatorio ambiental rodoanel trecho sul.pdf>. Acesso em: 26 abril 2014.

SECRETARIA DE TRANSPORTES DO ESTADO DE SÃO PAULO (São Paulo). Estudos Ambientais para a obtenção de Licença Ambiental Prévia. 2007. Disponível em:< ftp://ftp.sp.gov.br/ftpder/normas/gestao ambiental/IP-DE-SOO-

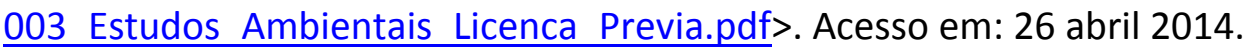

SOUZA, C. Políticas públicas: uma revisão de literatura. Sociologia, Ano 8, № 16, julho/dezembro, 2006.

SUBIRATS, J. El papel de la burocracia en el processo de determinación e implementación de las políticas públicas. In: SARAIVA, E.; FERRAREZI, E. (Org.). Políticas Públicas: Coletânea - Volume 2. Brasília: ENAP, 2006.

TATAGIBA, L. 2005. Conselhos gestores de políticas públicas e democracia participativa: aprofundando o debate. In: Revista de Sociologia Política, Curitiba, 25, p. 209-213, Nov. 2005.

UOL. Veja quais são os reservatórios de água da Grande SP. Disponível em: <http://noticias.uol.com.br/infograficos/2014/02/14/veja-quais-sao-os-reservatorios-deagua-da-grande-sp.htm>. Acesso: 01 maio 2014. 
URBAN, T. Saudades do matão. Curitiba: Editora Universidade Federal do Paraná, 2011.

UNITED NATIONS EDUCATIONAL, SCIENTIFIC AND CULTURAL ORGANIZATION - UNESCO, 2014. Mapa da Rede Mundial de Reservas da Biosfera 2012-2013. Pesquisa geral na homepage. Disponível em: < http://www.unesco.org/new/pt/brasilia/naturalsciences/environment/biodiversity/biodiversity/>. Acesso: 08 março 2014.

VASCONCELOS, D. M. Memória política, democracia e accountability: algumas reflexões teóricas. Coimbra: Centro de Estudos Sociais. 2009. Disponível em: < http://www.ces.uc.pt/publicacoes/oficina/ficheiros/330.pdf> . Acesso em 04 junho 2015.

WWF-Brasil; Programa de Preservação da Mata Atlântica; Fundação Florestal; Instituto Florestal. Rappam - Rapid Assessment and Prioritization of Protected Area Management: implementação da avaliação rápida e priorização do manejo de unidades de conservação do Instituto Florestal e da Fundação Florestal de São Paulo. São Paulo: WWF, Programa de Preservação da Mata Atlântica, Instituto Florestal de São Paulo, Fundação Florestal, Secretaria do Meio Ambiente do Estado de São Paulo, 2004. 42 p. 
APÊNDICE A -

TERMO DE CONSENTIMENTO LIVRE E ESCLARECIDO 
O sr(a) está sendo convidado(a) para participar da pesquisa intitulada: A Governança no Conselho gestor da APA Bororé-Colônia, a ser executada até maio de 2015. Meu nome é Juliana Ferreira de Castro, sou mestranda no Programa de Mudança Social e Participação Política da Universidade de São Paulo - USP e responsável pela realização desta pesquisa.

Após receber os esclarecimentos e as informações a seguir, no caso de aceitar fazer parte do estudo, assine ao final deste documento, que está em duas vias de igual teor. Uma delas é sua e a outra é do pesquisador responsável. Em caso de dúvida sobre a pesquisa, você poderá entrar em contato comigo pelo e-mail julianafc@usp.br ou pelo telefone (11) 98542-3869. Você será esclarecido(a) sobre a pesquisa em qualquer aspecto que desejar.

O objetivo desta pesquisa é compreender o processo de envolvimento e participação da sociedade civil na gestão da APA Bororé-Colônia. Sua participação nesta pesquisa consistirá em responder as perguntas a serem realizadas sob a forma de entrevista. A entrevista terá duração aproximada de 50 minutos e será gravada em gravador digital para posterior transcrição. Sua participação é voluntária.

O benefício relacionado à sua participação será o de aumentar o conhecimento científico para as áreas das Ciências Sociais, Turismo, Geografia e outras interessadas em compreender a dinâmica existente em uma Área de Proteção Ambiental, para colaborar com o desenvolvimento de mecanismos que visem a melhoria da qualidade de vida de suas populações.

A qualquer momento você poderá recusar-se a responder qualquer pergunta ou desistir de participar e retirar seu consentimento. Sua recusa não trará nenhum prejuízo em sua relação com a pesquisadora ou com a instituição na qual você trabalha.

O Sr (a) terá acesso ao material editado que será utilizado na pesquisa (transcrição parcial dos trechos de maior interesse) e também ao relatório produzido, podendo sugerir alterações. $\mathrm{O}$ sr (a) poderá solicitar, a qualquer momento, a supressão de seus depoimentos usados no relatório. O sr (a) receberá a transcrição parcial da entrevista, e se estiver de acordo irá assiná-la para e devolve-la para a pesquisadora. A pesquisadora se compromete a deixar uma cópia do resultado final da pesquisa no Conselho gestor da APA Bororé-Colônia até dezembro de 2015.

O Sr.(a) pode permitir ou não permitir o uso de seu nome ou material que identifique sua participação nesta pesquisa, assinalando uma das opções abaixo:

$\square$ Permito ser identificado como participante desta pesquisa.

$\square$ Permito que apenas as iniciais do meu nome apareçam nesta pesquisa.

$\square$ Não permito ser identificado nesta pesquisa, solicitando que depoimento não seja identificado.

Declaro estar ciente do inteiro teor deste TERMO DE CONSENTIMENTO e estou de acordo em participar do estudo proposto, sabendo que dele poderei desistir a qualquer momento, sem sofrer qualquer punição ou constrangimento. Recebi uma cópia assinada deste formulário de consentimento.

Colaborador da pesquisa

Nome:

RG:

Assinatura e data:
Responsável pela pesquisa

Nome: Juliana F. de Castro

RG: $32.220 .316-8$

Assinatura e data: 
APÊNDICE B -

ROTEIRO PARA ENTREVISTAS 
Qual é o papel do conselheiro? Esse papel tem sido cumprido?

O conselho dá conta de abarcar a diversidade social que existe na APA Bororé-Colônia?

Como são definidos os assuntos que são tratados em cada reunião do conselho?

Os conselheiros conseguem compreender com facilidade os assuntos tratados nas reuniões?

A quantidade de reuniões e a duração delas são suficientes para tratar os assuntos do conselho da $A P A B C$ ? E quanto a data, horário e o local de sua realização, são adequados?

Existem outros espaços externos ao conselho da APABC que discutam a UC e se relacionem com o conselho?

Como foi a criação do Regimento Interno do conselho gestor da APABC? Os conselheiros conhecem o Regimento Interno?

O Plano de Gestão da APABC é utilizado na rotina dos conselheiros?

O que precisa para que a sociedade participe mais do conselho gestor da APABC?

Hoje as informações sobre o conselho gestor da APABC estão disponíveis para os conselheiros acompanharem a gestão?

Existem projetos e ações de monitoramento do conselho gestor da APABC?

Quais são as maiores dificuldades e obstáculos que o conselho tem enfrentado? O conselho tem capacidade de experimentar e adotar novas estratégias?

Como é a prestação de contas no conselho da APABC? Quem presta contas do quê, para quem e como?

Como é a comunicação entre o conselho da APABC e a comunidade? As pessoas da comunidade conhecem a APABC? As informações sobre o conselho estão disponíveis para a comunidade acompanhar a gestão?

As demandas do conselho gestor da APABC são cumpridas? Quando não são cumpridas fica claro aos conselheiros a razão do insucesso?

A população local participou do processo de criação dos Parques Naturais Municipais Itaim, Jaceguava, Bororé e Varginha? De que forma? Quais foram as limitações?

Quais atividades a comunidade desenvolvia nos espaços onde foram criados os PNMs Itaim, Jaceguava, Bororé e Varginha?

Os conhecimentos dos habitantes locais foram usados de alguma forma na criação dos PNMs Itaim, Jaceguava, Bororé e Varginha?

Como se deu a delimitação da área dos PNMs Itaim, Jaceguava, Bororé e Varginha?

Como se deu a definição da categoria parque no caso dos PNMs Itaim, Jaceguava, Bororé e Varginha? 
ANEXO A -

LOCALIZAÇÃO DA APA BORORÉ-COLÔNIA E

PARQUES NATURAIS MUNICIPAIS BORORÉ, VARGINHA E ITAIM 


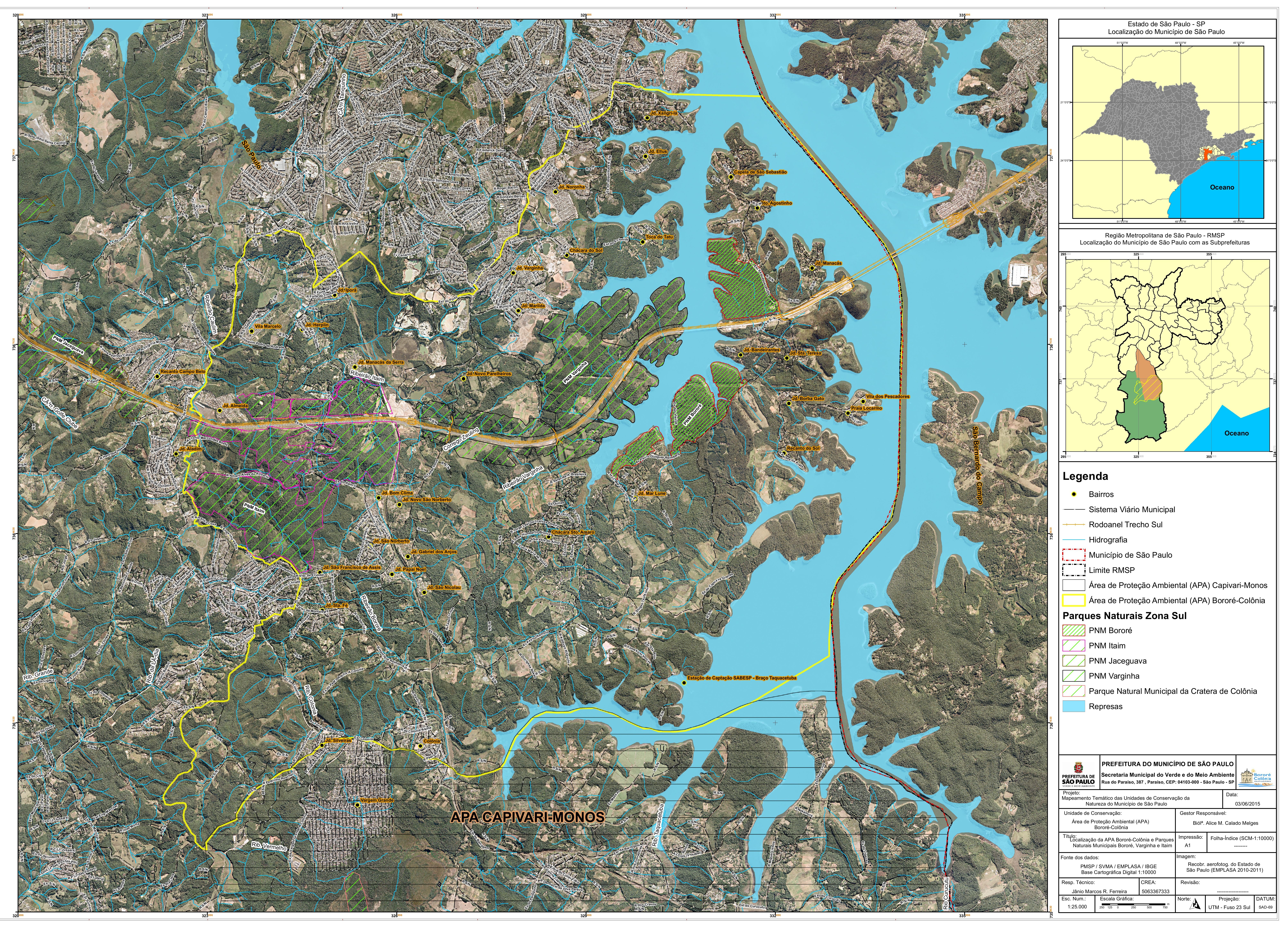


ANEXO B CONTEXTO DA PARTICIPAÇÃO SOCIAL NA POLÍTICA AMBIENTAL 


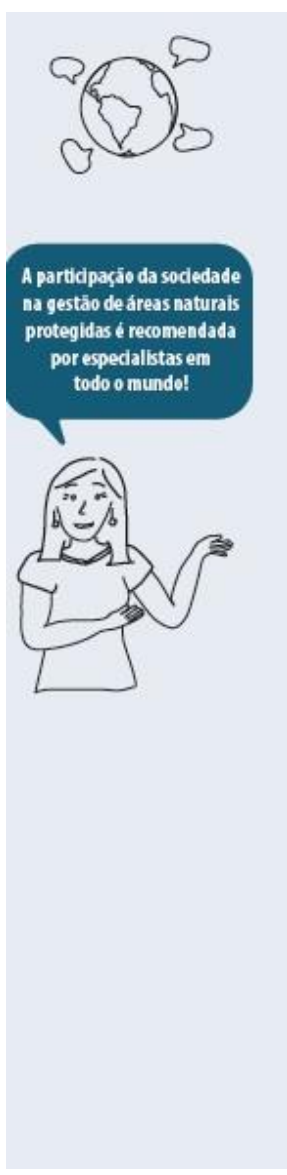

O que dizem os documentos internacionals e os clentistas

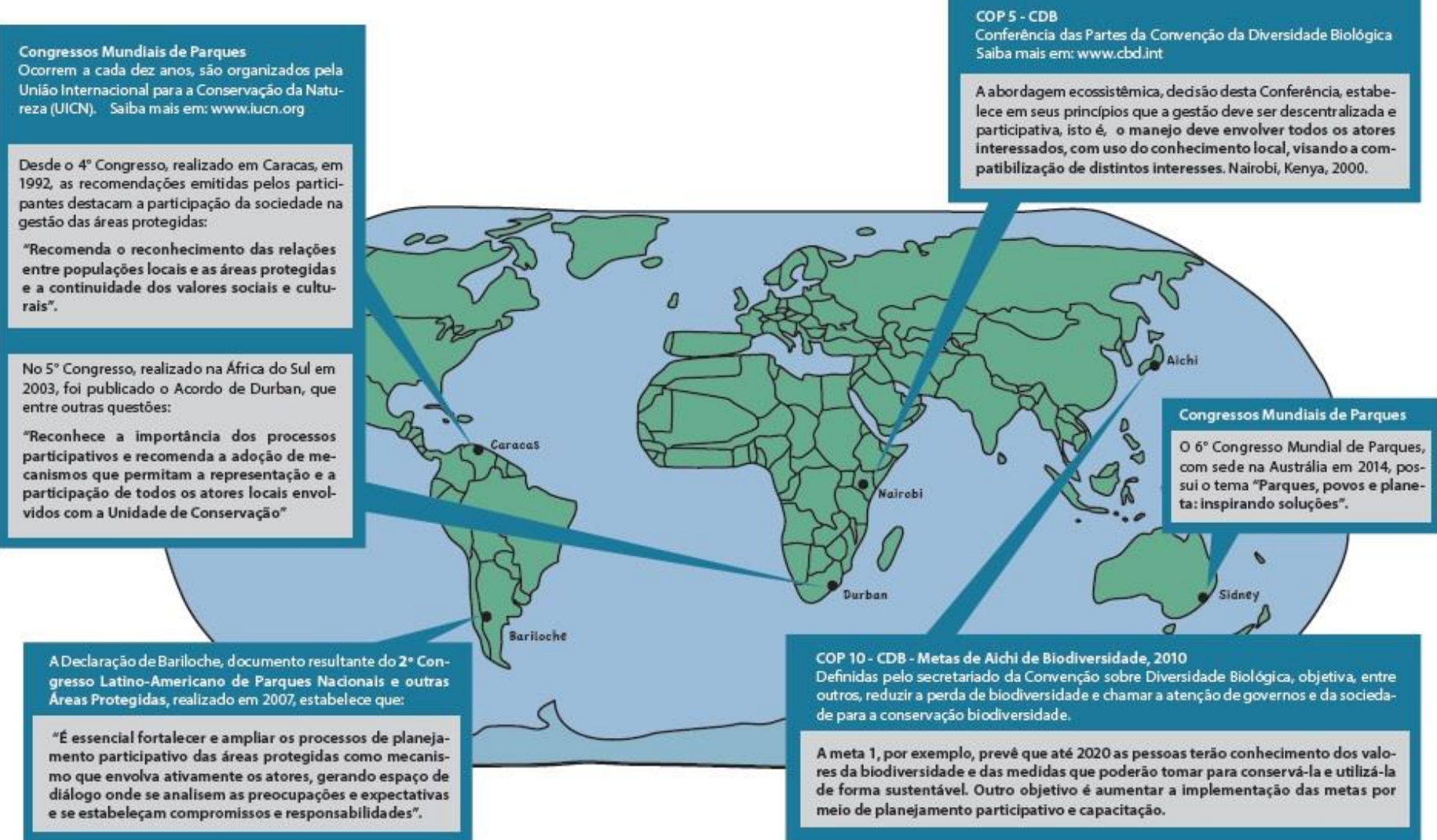

Administrar areass protegidas sem a participacădo das comunidades locais no̊oé (Corlett; Primack, 20c8)

Desde $04^{\circ}$ Congresso, realizado em Caracas, e aço da sociedade na e a continuidade dos valores sociais e cultu entre outras questóe

Fonte: ICMBIO, 2014

Oreconhecimento dopapelchave das comunidades locais de que a participaçăo efetiva trouxe beneficios para a corrervaç̧o eas comunidades emvarios locas do Brasil, Bensugn, 2006).

Otraco mais importantedos

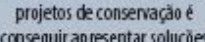
invoradoras, muitas delas desemolvidas em conjunto comas comunidades locais
(Rodrigues, 2002) 